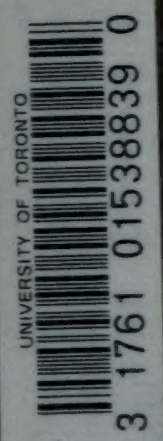


Digitized by the Internet Archive in 2007 with funding from Microsoft Corporation 


A BRIEF

\title{
HISTORY OF FORESTRY
}

In Europe, the United States

\author{
AND Other Countries
}

\section{BY \\ Bernhard Ed Fernow, LL.D.}

\section{Dean, Faculty of Forestry}

University of Toronto

$$
\frac{100141}{23 / 12 / 09}
$$

Univaesrry Pazss

Torowto, OwT. 


\section{To My Friend of Many Years ROSSITER W. RAYMOND}

whose warm personal interest and enthusiastic patriotism have from their beginnings inspired my labors in forwarding forestry interests in the United States. 


\section{ERRATA.}

Page 95-Line 23: for "Gustave Heyer" read "Karl Heyer."

Page 202-Line 16: for "1835" read "1853."

Page 221-Line 3: for " $1 \%$ " read " $6 \%$."

Page 236-Bottom line: for " 2.5 " read " 3 ".

Page 246-Lines 4 and 5: for "Beech and Oak, etc." read "Oak and other hardwood are here the principal trees with Scotch Pine and Spruce intermixed."

Page 259-Line 18: for " 30 " read "22", the term losting years".

Line 28: for "6" read "7".

Last line: for "8 months" read " 1 year".

Page 267-Line 4: after "end", insert "in 1737 and again".

Page 266-Line 2: for "Jylland" read "Sjulland".

Line 17 and 18: for "square miles" read "acres"

Page 353-Line 17: for " 500 " read " 350 ".

Line 18: for " 300 " read " 200 ".

Line 23: for " 40 " read " 60 ". 


\section{CONTENTS.}

RAGE.

PREFACE 。 . . . . . . . . ix

INTRODUCTORY • • . • . .

THE FOREST OF THE ANCIENTS • • • • - 8

GERMANY • . • • • • . . 21

I. From earliegt times to end of Middue Aaes . 25

1. Development of Property Conditions . 26

2. Forest Treatment . . . . . 34

II. Firgt Development of Forestry Metrods (1500 то 1800) . . . . . . . 39

1. Development of Property Conditions . . 40

2. Forest Conditions . . . . . 44

3. Methods of Restriction in Forest Use . . 46

4. Forest Policy . . . . . . 49

5. Personnel . . . . . . $\quad 52$

6. Development of Silviculture . . . . 53

7. Improvement of the Crop a . . . 62

8. Methods of Regulating Forest Mapagement . 64

9. Improvements in Methods of Mensuration . 68

10. Methods of Lumbering and Utilization . . 72

11. Forest Administration . . . . . 75

12. Forestry Schools . . . . . , 78

13. Forestry Literature . . . . . 79

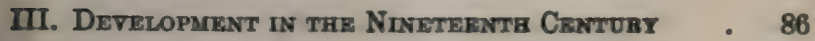

1. Changes in Property Conditions . . . 86

2. Forest Conditions . . . . . 90

3. Pereonnel . . . . . . . . 91 
III. Devinopment in the Ningtementh Centurt.-(Cont.)

4. Progress in Silviculture . . . . 96

5. Methods of Forest Organization . . 106

6. Forest Administration . . . . . 112

7. Forest Policy . . . . . . 117

8. Forestry Science and Literature . . . 121

9. Means of Advancing Forestry Science . . 135

AUSTRIA-HUNGARY . . . . . 141

1. Property Conditions . . . . 146

2. First Attempts at Forest Control . . . 147

3. State Forest Administration . . . . 150

4. Development of Forest Policy . . . 152

5. Progress of Forest Organization . . . 155

6. Development of Silviculture . . . . 158

7. Education and Literature . . . . 160

Hungary . . . . . . . 164

SWITZERLAND $. \quad . \quad . \quad . . . \quad 170$

FRANCE - • • • • • • • . 186

1. Development of Forest Property . . . 187

2. Development of Forest Policy . . . 191

3. Present Conditions, and Administration . 197

4. Reforestation . . . . . . 199

5. Forestry Science and Practice . . . 207

6. Education and Literature . . . . 209

RUSSIA AND FINLAND • • • • • 217

1. Forest Conditions . . . . . 218

2. Ownership . . . . . . 221

3. Development of Forest Policy - . . 222

4. Education and Literature . . . . 228

5. Forestry Practice . . . . . 232 


\section{Contents.}

THE SCANDINAVIAN STATES .

I SWRDAK . . . . . . . . 245

1. Property Conditions . • • . . 247

2. Development of Forest Policy . . . 250

3. Forest Administration and Forest Practice . 257

4. Education and Literature . . . . 259

NORWAY . . . . . . . . 260

Dremarat . . . . • . . . 265

THE MEDITERRANEAN PENINSULAS • . . 271

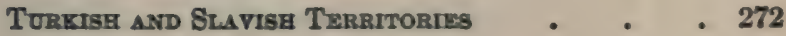

Geezcy • • • • • • • • 277

1. Forest Conditions . . . . . 277

2. Development of Forest Policy . . . 280

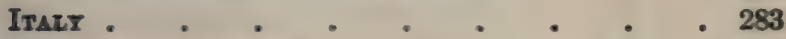

1. Forest Conditions _ . . . . 286

2. Development of Forest Policy a . . 288

SPADY • • • • • • • • •

1. Forest Conditions . . . . . 298

2. Development of Forest Policy . . . 300

Pomtrgat • • • • 305

GREAT BRITAIN AND HER COLONIES . . . 308

1. Forest Conditions . . . . . 310

2. Development of Foreat Policy . . . 312

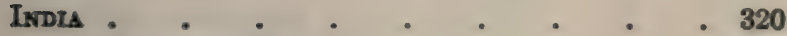

1. Forest Conditions . . . . . 323

2. Property Conditions . . . . . 328

3. Development of Forest Policy . . . 331

4. Forest Organization and Management . . 336

5. Forest Treatment • • • . . 340

6. Education and Literature ${ }^{\circ}$. . . . 345 


\section{GREAT BRITAIN AND HER COLONIES.-(Cont.)}

PAGR.

Camada . . . . . . . . 348

1. Forest Conditions . . . . 353

2. Ownership . . . . . . 359

3. Development of Forest Policy . . . 362

NEWFOUNDLAND . . . . . . . . 372

Other British Possessions and Coronies . . 373

JAPAN * . ., 377

1. Forest Conditions . . . . 278

2. Development of Forest Policy . . . 381

KORRA . . . . . . . . . . . 388

UNITED STATES OF AMERICA . . . . 390

1. Forest Conditions . . . . 395

2. Early Forest History . . . . . 400

3. Development of Forest Policy . . . 412

4. Education and Literature . . . . . 431

Insular Possessions . . . . . . . . 436 


\section{PREFACE.}

This publication is the result of a series of 25 lectures which the writer was invited to deliver before the students of forestry in Yale University as a part of their regular course of instruction.

Circumstances made it desirable, in the absence of any existing textbooks on the subject, to print at once, for the sake of ready reference, the substance of the lectures while they were being delivered.

This statement of the manner in which the book came into existence will explain and, it is hoped, excuse the crudities of style, which has been also hampered by the necessity of condensation.

The main object was to bring together the information, now scattered and mostly inaccessible to English or American readers: the style has been sacrificed to brevity; it is a book of expanded lectare notes.

In the nature of the case the book does not lay claim to any originality except in the manner of presentation, being merely a compilation of facts gathered mostly from other compilations, official documents and journals.

For none of the countries discussed does a complete work on the history of forests and forestry exist, excepting in the case of Germany, which can boast of a number of comprehensive works on the subject. It was, therefore, possible to treat that country more in extenso. Moreover it appeared desirable to enlarge upon the history of that country, since it is pre-eminently in the lead in forestry matters and has passed through all the stages 
of development of forest policies and forestry practice, which, with more or less variations must be repeated in other countries.

Especially the growth of the technical science and art of forestry, which has been developed in Germany for a longer time and to a more refined degree than in other countries, has been elaborated in the chapter relating to that country.

For some of the other countries available sources of information were quite limited. The writer believes, however, that for the purpose of this brief statement the data collected will be found sufficient.

In order to make conditions existing in the different countries, and their causes more readily understood it appeared desirable to give very brief historic references to their political and economic development and also brief statements of their general physical conditions.

Present conditions of forest policy and forest administration have sometimes been enlarged upon beyond the requirements of historical treatment.

ITHACA, N. Y., May, $190 \%$ B. E. FERNow.

The desire of several Forest Schools to use this rolume as a textbook necessitated its publication in incomplete form, namely before the last chapter, on the United. States, had been written; the author being prevented by other work from completing it until two years later.

As a consequence the history of the United States and of Canada could be brought forward to a later date than that of other nations. For advances in these, the Forestry Quarterly may be consulted.

Toronto, October, 1909.

B. E. F. 


\section{INTRODUCTORY.}

The value of studying the historical development of an economic subject or of a technical art which, like forestry, relies to a large extent upon empiricism, lies in the fact that it brings before us, in proper perspective, accumulated experience, and enables us to analyze cause and effect, whereby we may learn to appreciate the reasons for present conditions and the possibilities for rational advancement.

If there be one philosophy more readily derivable than another from the study of the history of forestry it is that history repeats itself. The same policies and the same methods which we hear propounded to-day have at some other time been propounded and tried elsewhere: we can study the results, broaden our judgment and avoid the mistakes of others.

Such study, if properly pursued, tends to free the mind from many foolish prejudices and particularly from an unreasonable partiality for our own country and its customs and methods, merely because they are our own, substituting the proper patriotism, which applies the best knowledge, wherever found, to our own necessities.

Nowhere is the record of experience and the historic method of study of more value than in an empiric art like forestry, in which it takes decades, a lifetime, nay a century to see the final effects of operations.

Forestry is an art born of necessity, as opposed to arts 
of convenience and of pleasure. Only when the natural supplies of forest products give out under the demands of civilization, or when unfavorable conditions of soil or climate induced by forest destruction necessitate a husbanding of supplies or necessitate the application of art or skill or knowledge in securing a reproduction, does the art of forestry make its appearance. Hence its beginnings occur in different places at different times and its development proceeds at different paces.

In the one country, owing to ecomomic development, the need of an intensive forest management and of strict forest policies may have arrived, while in another rough exploitation and wasteful practices are still natural and practically unavoidable. And such differences, as we shall see, may even exist in the different parts of the same country.

The origin and growth of the art, then, is dependent on economic and cultural conditions and economic development and on other elements of environment, and can only be understood and appreciated through the knowledge of such environment, of such other conditions and development, as that of the use of the soil, of industries, of means of transportation, of civilization generally.

Hence we find, for instance, that England, located so as to be accessible by sea from all points of the compass and with oceanic shipping well developed, can apparently dispense with serious consideration of the forest supply question.

Again we find, that more than a century ago fear of a timber famine agitated not only the dense populations of many European countries, but even the scanty popu. 
lation of the United States, in spite of the natural forest wealth which is still supplying us, and with good reason, for at that time wood was the only fuel and rivers the only means of transportation; hence local scarcity.was to be feared and was not unfrequently experienced when accessible forest areas had been exploited. Railroad and canal development and the use of coal for fuel changed this condition in both continents. Now, with improved means of transportation by land and by sea the questions of wood supply and of forestry development, which at one time were of very local concern, have become world questions and he who proposes to discuss intelligently forest conditions and forestry movement in one country must understand what is going on in other countries.

As will appear from the study of the following pages, with the exception of some parts of central Europe or of some sporadic attempts elsewhere to regulate forest use, the development of the forestry idea belongs essentially to the 19th century, and more especially to the second half, when the rapid development of railroads had narrowed thelworld, and the remarkable development of industries and material civilization called for increased draft on forest resources.

Yet we are still largely ignorant of the extent of availble forest area, not only in this country but elsewhere; whether it is sufficient in extent and yield to furnish a continuous supply for the needs of our civilization, and if not, for how long a time it will suffice. We can only make very broad statements and very broad inferences from them as to questions of wood supply as an argument for the need of a closer study of forest conditions and forestry: 
1. Practically only the northern temperate zone produces the kinds of wood which enter most largely into our economy, namely the soft conifers and the medium hard woods; the woods of the tropics are mainly very hard, fit for ornamental use mainly and less necessary. Possibly a change in the methods of the use of wood may change the relative economic values, but at present the vast forests of the tropical countries are of relatively little importance in the discussion of wood supply of the world.

2. The productive forest area of the temperate zone, in which the industrial nations are located, has continuously decreased. We shall not be far from wrong in stating this area liberally, to be around 2,500 million acres, namely in Europe, 800 million acres; in Asia, 800 million acres; in North America, 900 million acres. How much of this acreage is available virgin timber, how much merely potential forest, how much growing crop, it is impossible to state.

3. The civilized wood consuming population of this territory is about 500 million, hence the per capita acreage is still 5 acres. Taking the European countries which now have to import all or part of their consumption (excess over exports), we find that their population is estimated at 180 million and that they use 40 cubic feet of wood per capita, of which 15 cubic feet is log timber; or altogether 2,700 million cubic feet of this description, of which they import in round numbers 1,000 million at a cost of about 250 million dollars ; their forest acreage of 90 million acres being insufficient to produce, even under careful management as in Germany, quite two-thirds of their needs. And the consumption in all 
these nations is growing at the rate of $11 / 2$ to 2 per cent. annually.

4. The deficiency is at present supplied by the export countries, Russia, Sweden, Norway, Austria-Hungary, Canada and United States, and these countries are also increasing their consumption and are beginning to feel the drain on their forest resources, which are for the most part merely roughly exploited.

5. If we assume a $\log$ timber requirement by the 500 million people of 7,500 million cubic feet and could secure what France annually produces, namely a little less than 9 cubic feet of such timber per acre, the area supposed to be under forest would amply suffice. But a large part of it is in fact withdrawn from useful production and of the balance not more than 250 million acres at best are under management for continuous production. Hence attention to forestry is an urgent necessity for every industrial nation.

The history of the forest in all forest countries shows the same periods of development.

First hardly recognized as of value or even as personal property, the attitude of the settler to the forest is of necessity inimical: the need for farm and pasture leads to forest destruction.

The next stage is that of restriction in forest use and protection against cattle and fire, the stage of conservative lumbering. Then come possitive efforts to secure re-growth by fostering natural regeneration or by artificial planting: the practice of silviculture begins. Finally a management for continuity-organizing existing 
forest areas for sustained yield-forest economy is introduced.

That the time and progress of these stages and the methods of their inauguration vary in different parts of the world is understood from the intimate relation which, as has been pointed out, this economic subject bears to all other economic as well as political developments.

At the present time we find all the European nations practicing forestry, although with a very varying degree of intensity. The greatest and most universal development of the art is for good reasons to be found in Germany and its nearest neighbors. Early attention to forest conservancy was here induced by density of population, which enforces intensity in the use of soil and by the comparative difficulty of securing wood supplies cheaply enough from outside. On the other hand, such countries as the Mediterranean peninsulas by their advantageous situation with reference to importations, with their mild climate and less intensive industrial development, have felt this need less.

Again, the still poorly settled and originally heavily timbered countries of the Scandinavian peninsula and the vast empire of Russia are still heavy exploiters of forest products and are only just beginning to feel the drain on their forest resources; while the United States, with as much forest wealth as Russia, but a much more intensive industrial development, has managed to reach the stage of need of a conservative forest policy in a shorter time.

From each of the European countries we learn something helpful towards inaugurating such policies, and 


\section{Introductory.}

9 rhile, owing to a different historical background and to lifferent political and social conditions, none of their Idministrative methods and measures may appeal to us, he principles underlying them as well as those underlyng their silvicultural methods remain the same and re applicable everywhere and can best be recognized ad studied in the history of their development. 


\section{THE FOREST OF THE ANCIENTS.}

The forest was undoubtedly the earliest home i mankind, its edible products forming its principal valuf Its wild animals developed the hunter, first furnishirg means of subsistence and then exhilaration and pleasue. Next, it was the mast and, in its openings, the pasure which gave to the forest its value for the herde:- and only last, with the development into settled commenities and more highly civilized conditions of life, did tha wood product become its main contribution toward that civilization. Finally, in the refinement of cultural conditions in densely settled countries is added its influence on soil, climate and water conditions.

Although there is no written history, there is little doubt that these were the phases in the appreciation of woodlands in the earliest development of mankind, for we find the same phases repeated in our own times in all newly settled countries.

As agriculture develops, the need for farming ground overshadows the usefulness of the forest in all these directions, and it is cleared away; moreover, as population remains scanty, a wasteful use of its stores forms

Waldgeschichte des Alterthums, by Argust SEIDENSTICKER, 1886, 2 vols., pp. 863 , is a most painstaking compilation from original sources of notes regarding the forest conditions and the knowledge of trees, forests and forestry among the ancients. Contains also a full bibliography.

Die Waldwirthschaft der Romer, by J. TRURIG, collects the knowledge, especially of arboriculture and silviculture, possessed by the Romans.

Forstwissenschaftliche Leistungen der Altgriechen, by Dr. CHLOROS, is Forstwissenschaftliches Centralblatt, 1885, pp. 8.

Archeologia forestale, Dell 'antica storia e giurisprudenzia forestale in Italia, by A. DI BERANGer, 1859. 
1e rule, until necessity arises for greater care in the xploitation, for more rational distribution of farm and rest area, and finally for intentional reproduction of rood as a useful crop.

Correspondingly forest conditions change from the ensely forested hills and mountain slopes during the ge of the nomad and hunter to the "enclaves" or patches f field and pasture enclosed by the forest of the first armers, then the opening up of the valleys and lowInds, while the hills and mountain farms return to prest and finally with the increase of population and vilization in valleys and plains a reduction of the forst area and a decrease of forest wealth.

While we have many isolated references to forest conitions and progress of forest exploitation among the pcients in the writings of poets and historians, these re generally too brief to permit us to gain a very clear icture of the progress of forest history; except in isoted cases, they furnish only glimpses, allowing us to 11 in the rest to some extent by guess.

That the countries occupied and known to the anents, eren Spain and Palestine, were originally wellfoded there seems little doubt, although in the drier gions and on the drier limestone soils, the forest was erhaps open as is usual under such conditions, and uly arid, forestless regions were also found where they rist now. Although it has been customary to point out me of the Mediterranean and Eastern countries as aving become deserts and depopulated through deforstation, and although this is undoubtedly true for 
some parts, as Mount Lebanon and Syria, generalizatios in this respect is dangerous.

We know, however, that by the 11th century befor Christ in Palestine, Asia Minor and Greece, especiall: in the neighborhood of thriving cities, the forest cove had vanished to a large extent and building timber fo the temples at Tyre and Sidon had to be brought lon distances from Mount Lebanon, whose wealth of ceda was also freely drawn upon for ship timber and othe structures. The exploitation of this mountain fores although about 465 B. C. Artaxerxes I, having recog nized the pending exhaustion, had attempted to regulat the cutting of timber, had by 333 B. C. progressed t such an extent that Alexander the Great found at lear the south slope exhausted and almost woodless.

The destruction by axe and fire of the celebrated fo ests of Sharon, Carmel and Bashan is the theme of th prophet Isaiah about 590 B. C.; and the widesprea devastation of large forest areas during the Jewish wa is depicted by Josephus. In Greece the Persian wa are on record as causes of widspread forest destruction Yet in other parts, as on the island of Cyprus, whic originally densely wooded, had rapidly lost its fore wealth during Cleopatra's time through the develo; ment of mining and metallurgical works, ship buildir and clearing for farms, the kings seemed to have ber able to protect the remnants for a long time, so th: respectable forest cover exists even to date.

The Romans seem to have had still a surplus of sh. timber at their command in the third and second ce turies before Christ, when they did not hesitate to bus the warships of the Carthaginians (204 B. C.) and 
the Svrians (189 B. C.), although other considerations may have forced these actions. Denuded hills and scarcity of building timber in certain parts are mentioned at the end of the third century before Christ, and that the need for conservative nse of timber resources had arrived also appears from the fact that when (167 B. C.) the Romans had brought Macedonia under their sway, the cutting of ship timber in the extensive forests of that country was prohibited. Although at that time the Roman State forests were still quite extensive, it is evident that under the system of renting these for the mast and pasture and for the exploitation of their timber to a company of contractors, their devastation was then rapidly progressing. Yet, on the whole, with local exceptions, Italy remained well wooded until the Christian exa.

In Spain, according to Diodorus Siculus (about 100 B. C.), the Southern provinces were densely wooded when about $200 \mathrm{~B}$. C. the Romans first took possession; but a great forest fire starting from the Pyrenees ran over the country, exposing deposits of silver ore which invited a large influx of miners, the cause of reckless deforestation of the country. The interior of this peninsula, however, was probably always forestless or at least scantily wooded.

While through colonization, exploitation, fire and other abuse, the useful forest area was decimated in many parts, the location of the Mediterranean peninsular countries was such that wood supplies could be readily secured by water from distant parts, and the lignarii or wood merchants of Italy drew their supplies even from India by way of Alexandria; they went for Ash to 
Asia Minor; for Cedar to Cilicia; Paphlagonia, Liguria and Mauritania became the great wood export countries. It is interesting to note that a regular wood market existed in Rome, as in Jerusalem, and at the former place firewood was sold by the pound (75c per $200 \mathrm{lbs}$., in Cicero's time). At the same time that the causes of devastation were at work the forest area also increased in some parts, recovering ground lost through wars and the neglect of farms, much less by active effort, although planting of trees in parks, vineyards and groves was early practiced to a limited extent.

As to development of forest property we have also only fragmentary information.

Nomads do not know soil as property. When they become settled farmers the plowland, the vineyard or olive grove and orchard are recognized as private property, but all the rest remains common property or nobody's in particular; and even the private property was not at first entirely exclusive. Hence for a long time (and in some parts even to date) the exclusive property right in forests is not fully established. At least the right to hunt over all territory without restriction was possessed by everybody, although an owner might prevent undesirable hunters from entering his enclosed property. The setting aside of hunting grounds for private use came into existence only in later Roman times. But woodland parks, planted or otherwisc, like the "paradises" of the Persian kings and the nemora of the Romans and Carthaginians were early a part of the private property of princes and grandees from which others were excluded. 
Forests formed a barrier and defense against outsiders, or a hiding place in case of need, hence we find frontier forests, or as the Germans called them "Grenzmarken," set aside or designated for such purposes and withdrawn from use in early times, and sometimes additionally fortified by ditches and other artificial barriers. Even before the "Grenzmarken" of the Germans the forest was used to designate the limit of peoples as well as to serve as a bulwark against attacks from invaders by Greeks, Romans and still earlier among Asiatic tribes.

Again, the Pantheistic ideas of the ancients led to consecrating not only trees but groves to certain gods: holy groves were frequent among the Greeks and Romans, and also among other pagans; the Jews, however, were enjoined to eradicate these emblems of paganism in the promised land with axe and fire, and they did so more or less, removal and re-establishment of holy groves varying according to the religious sentiment of their rulers. Altogether, in Palestine the forests were left to the free and unrestricted use of the Israelites.

Out of religious conceptions and priestly shrewdness arose church property in farms and forests among the Indian Brahmans, the Ethiopians and Egyptians, as also among Greeks and Romans.

It appears that the oriental kings were exclusive owners of all unappropriated or public forests. This was certainly the case with the princes of India and of Persia and such ownership can be proved definitely in many other parts, as with the forests of Lebanon, of Cyprus and various forest areas in Asia Minor. 
That the Greek republics had mainly public forests seems to be likely; for Attica, at least, this is true without doubt.

While the first Roman kings seem to have owned royal domains, which were distributed among the people after the expulsion of the kings, the public property which came to the republic as a result of conquest was in most cases at once transferred to private hands, either for homesteads of colonists or in recognition of services of soldiers and other public officers or to mollify the conquered, or by sale or for rent, not to mention the rights acquired by squatters. The rents were usually farmed out to collectors (publicani) or corporations formed of these, but Livy mentions State forests in which the cutting was regulated, probably largely merely reserving the ship timber.

That single cities and other smaller units owned common forest properties occasionally seems also established.

Private forest properties connected with farm estates existed in Ethiopia, in Arabia, among the Greeks and among the Romans at home as well as in their colonies. Especially pasture woods (saltus) connected with small and large estates (latifundia) into which probably most forest areas near settlements were turned, are frequently mentioned as in private ownership; but also other private forests existed.

The institution of servitudes or rights of user (usus and usus-fructus) and a considerable amount of law regarding the conditions under which they were exercised and regarding their extinguishment were in existence among the Romans in the first centuries of the Christian era. 
Restrictions in the use of woods were not entirely absent, but with the exception of reserving ship timber in the State forests, they refer only to special classes of forest.

In the frontier forests reserved for defensive purposes, and in the holy groves set aside by private or public declaration, no wood could be cut thereafter, being considered nobody's property but sanctified and dedicated to religious use (res sacra). and whoerer remored any wood from them was considered a "patricide," except the cutting be done for purposes of improvement (thinnings) and after a prescribed sacrifice.

With the extension of Christendom the holy trees and grores became the property of the emperors, who sometimes substituted Christian holiness for the pagan, and retained the restrictions which had preserved them. Thus the cutting and selling of cypress and other trees in the holy grore near Antioch, and of Persea trees in Egypt generally (which had been deemed holy under the Pharaos) was prohibited under penalty of fire pounds gold, unless specially permitted.

In Attica as well as in Rome the theory that the State cannot satisfactorily carry on any business was well established. Hence the State forests were rented out, under a system of time or perpetual rent, the renters after exploiting the timber subletting merely the pasture, except where coppice could be profitably utilized. The officials with titles referring to their connection with the woods, as the Roman saltuarii or the Greek hyloroi (forestguards) and villicus silvarum, the overseer, both slares, had hardly even police functions. 
Forest management proper, i. e., regulated use for continuity, except in coppice, seems nowhere to have been practiced by the ancients, although silviculture in artificial plantations, or rather arboriculture, was well established and even attempts at replacement in the selection forest seem to have occasionally been made. Not only were many arboricultural practices of to-day well known to them, but also a number of the still unsettled controversies in this field were then already subjects of discussion.

The culling system of taking only the most desirable kinds, trees and cuts, which has characterized until recently our American lumbering methods was naturally the one under which the mixed forest was utilized. Fire used in the pasture woods for the same purposes as with us effectively prevented reproduction in these and destroyed gradually the remnants of old trees.

Only where for park and hunting purposes some care was bestowed upon the woodland, was reproduction purposely attempted, as, for instance, when an underwood was to be established for game cover in a hunting park.

The treatment of the coppice and methods of sowing and planting were well understood in spite of the lack of natural sciences. Whatever forestry practice existed was based on empirical observations and taught in the books on agriculture as a part of farm practice.

For Greece, we find, besides what can be learned from the historians Herodotus and Xenophon and from the natural history of Aristotle, the first work on plant history and wood technology, if not forestry, in 18 vol- 
umes by Theophrastus (390-286 B. C.), a pupil of Aristotle and Plato.

Among the Romans, besides a number of historians, at least three writers before Christ discussed in detail agriculture and, in connection with it, tree culture: namely, Cato (234-149 B. C.) who wrote an excellent work De re rustica, in 162 chapters; Varro (116-26 B. C.), also De re rustica, in three books; and Vergitius Maro (70-19 B. C.), who in his Georgica records in six books the state of knowledge at that time. Of the many writers on these subjects after Christ there are also three to be mentioned, namely, Cajus Plinius Major (23-79 A. D.), who in his Historia naturalis, in $3 \hat{\imath}$ books, discusses also the technique of silviculture; Lucius Junius Moderatus Columella (about 50 A. D.), with 12 books, De re rustica, and one book De arboribus, the former being the best work of the ancients on the subject; and Palladius, writing about 350 A. D., 13 books, De re rustica, which in the original and in translations was read until past the middle ages.

Only a few references which exhibit the state of knowledge on arboricultural subjects among the Romans may be cited, and some of this knowledge was also dereloped in Greece and found application, more or less, through the Roman empire from India to Spain.

Nursery practice was already well known to Cato, while Varro knew, besides sowing and planting, the art of grafting and layering, and Columella discusses in addition pruning and pollarding (which latter was practiced for securing fuelwood), and the propriety of leav- 
ing the pruned trees two years to recuperate before applying the knife again.

The method of wintering acorns and chestnuts in sand, working them over every 30 days and separating the poor seed by floating in water, is known, and the same writer discusses nursery management with minute detail, even the advantages of transplants and of doubly transplanted material. The question whether to plant or to sow, and the preference of fall or spring planting with distinction for different species and localities are much discussed; and preference of sowing oak and chestnut instead of transplanting is pointed out with good reasons.

Pliny, the Humboldt of the ancients, recognizes tolerance of different species, the need of different treatment for different species, the desirability of transplanting to soil and climatic conditions similar to those to which the tree was accustomed, and of placing the trees as they stood with reference to the sun. But, to be sure, he also has many curious notions, as for instance his counsels to set shallow rooted trees deeper than they stood before, his advice not to plant in rain or wind and his laying much stress on the phases of the moon as influencing results.

Silviculture was mainly developed in connection with the coppice, which was systematically practiced for the purpose of growing vineyard stakes, especially with chestnut (castanetum), oak (quercetum), and willow (salicetum), while the arbustum denoted the plantings of trees for the support of grapes, and incidentally for the foliage used as cattle feed, still in vogue in modern Italy. 
This planting of vine supports was done with saplings of elm, poplar and some other species; by pollarding and by a well devised system of pruning these were gradually prepared and maintained in proper form for their purpose.

The coppice seems to have been systematically managed in Attica as well as in Italy in regular fellings; the mild elimate producing sprouts and root suckers readily without requiring much care, even conifers (cypress and fir) reproducing in this manner.

The oak coppice was managed in 7 year rotation, the chestnut in 5 year, and the willow in 3 year rotation.

Yield and profitableness are discussed, and the practice of thinnings is known, but only for the purpose of removing and using the dead material.

Forest protection was poorly developed: of insects little, of fungi no knowledge existed. Hand-picking was applied against caterpillars, also ditches into which the beetles were driven and then corered; the use of hogs in fighting insects was also known. That goats were undesirable in the woods had been observed. Some remarkably precocious physiological knowledge or rather philosophy existed: it was recognized that frost produces drought and that a remedy is to loosen the soil, aerating the roots, to drain or water as the case might require, and to prune; but also sap letting was prescribed. Against hail hang up dead owls; against ants, which were deemed injurious, ashes with rinegar were to be applied, or else an ass's heart.

Curiosities in wood technology were rife and many contradictions among the wood sharps existed, as in our times. Only four elements, earth, water, fire, air, com- 
posed all bodies: the more fire in the composition of a wood, the more readily would it decay. Spruce being composed of less earth and water, but more fire and air, is therefore lighter than oak which, mostly composed of earth, is therefore so durable; but the latter warps and develops season splits because on account of its density it cannot take up readily and resists the penetration of moisture.

Wood impregnation, supposed to be a modern invention, was already practiced; cedrium (cedar oil) being used as well as a tar coating or immersion in seawater for one year, to secure greater durability.

While then the ancients were not entirely without silvicultural knowledge, indeed possessed much more than is usually credited to them, the need of a forest policy and of a systematic forest management in the modern sense had not arisen in their time; the mild climate reducing the necessity of fuelwood and the accessibility by water to sources of supply for naval and other construction delaying the need for forest production at home.

There is little doubt, that some of the agricultural and silvicultural knowledge and practice of the Romans found entrance among the German tribes who, especially the Allemanni, came into contact with the Romans in their civilized surroundings during the fourth century. 


\section{GERMANY.}

It is generally conceded that both the science and art of forestry are most thoroughly developed and most intensively applied throughout Germany. It must, however, not be understood that in the practical application of the art perfection has been reached anywhere, or that the science, which like that of medicine has been largely a growth of empiricism, is in all parts safely based; nor are definitely settled forest policies so entrenched, that they have become immutable. On the contrary, there are still mismanaged and unmanaged woods to be found, mainly those in the hands of farmers and other private owners; there are still even in well managed forests practices pursued which are known not to conform to theo-

Besides a dozen or more earlier histories of forestry in Germany, some of which date back to the beginning of the $19 \mathrm{th}$ century, there are two excellent modera compilations, namely:

Geschichte des Wuldeigenthums, der Waldwirtschaft und Forstwissenschaft in Deutschland, by August Bershardt, 18T2-75, 3 Vols., 1002 pp., a classic, which treats especially extensively of political and economic questions having a bearing on the development of forestry; and

Handbuch der Forst-und Jagdgeschichte Deutscklands, by ADAM SCHWAPPACH, 1886, 2 Vols., 892 pp., which appeared as a second edition of Bernhardt's history abridging the political hiseory and expanding the forestry part. This volume has been mainly followed in the following presentation of the subject. In condensed form this history is also to be found in LoREv's Handbuch der Forstwissensckaft, 1888, Vol. I, pp. 143-210.

In Schwappach's history a full list of original sources is enumerated These are, for the oldest period, Roman writers, which are unreliable; the laws of the various German tribes; the laws of kings (Capitularia) : the laws of villages and other territorial districts; "Weisthümer" (judgments); inventories of properties (especially of churches and cloisters); documents of business transactions and chronicles. For the time after the Middle ages the most important source is found in the Forest Ordinances of princes and other forest owners; forest laws ; police orders; business documents and finally special literature. 
retical ideals, and others which lack a sure scientific foundation; and while the general policy of conservative management and of State interest in the same is thoroughly established, the methods of attaining the result are neither uniform through the various States which form the German Federation, nor positively settled anywhere. In other words the history of forestry is still, even in this most advanced country, in the stage of lively development.

For the student of forestry the history of its development in Germany is of greatest interest not only because his art has reached here the highest and most intensive application, but because all the phases of development through which other countries have passed or else will eventually have to pass are here exemplified, and many if not most of the other countries of the world have been at least influenced by German precedent or have more or less followed German example; there is hardly a policy or practice that has not at some time in some part been employed in the fatherland of forestry.

One reason for this rich historical background is the fact, that Germany has never been a unit, that from its earliest history it was broken up into many independent and, until modern times, only loosely associated units, which developed differently in social, political and economic direction. This accounts also for the great variety of conditions existing even to-day in the 26 principalities which form the German empire.

The 208,830 square miles of territory,* which supports a population of $5 \%$ million people, still contain a forest area of a round 35 million acres (26\% of the

\footnotetext{
* The statistics in this book do not pretend to be more than approximations.
} 
land area) or .63 acre per capita, which although largely under conservative management has long ago ceased to supply by its annual increment (about 53 cubic feet per acre) the needs of the population; the imports during the last 40 years, when Germany began to show excess of imports over exports, having grown in volume at the average rate of $10 \%$ to now round 300 million cubic feet ( 80 million dollars) or $15 \%$ of the consumption.

The larger part of Germany, two thirds of the territory and population is controlled by modern Prussia. with a total forest area of 25 million acres; Bavaria comes next with one seventh of the land area and 6 million acres of forest; the five larger states of Würtemberg, Baden, Saxony, Mecklenburg and Hesse, occupying together another serenth of the territory with 5 million acres of forest. The balance of the area is divided among the other 19 states.

Fifty per cent. of Germany roughly speaking, is plains country, the larger part in the northern and eastern territory of Prussia, 25\% is hill country, mostly in West and Middle Germany and 25\% mountain country, the larger portion in the southern states.

There are at best only five species of timber of high economic general importance, the (Scotch) pine which covers large areas in the northern sandy plain and the lighter soils in the south; the (Norway) spruce and (Silver) fir which form forests in the southwestern and other mountain regions and represent, in mixture with broadleaf forest, a goodly proportion in the northeastern lowlands; the (English) oak, of which botanically two species are recognized, and the beech being the most important 
hardwoods found throughout the empire, but especially highly developed in the west and southwest. In addition there are half a dozen species of minor or more local importance, but the five mentioned form the basis of the forestry systems.

Politically it may be mentioned that out of the very many independent principalities, variable in number from time to time, into which the German territory had been divided, the 26 which had preserved their autonomy formed in $18 \% 1$ the federation of States, known as the German Empire. Each of these has its own representative government including the forest administration, very much like the United States; only the army and navy, tariff, posts, telegraphs, railroads, criminal law and foreign policy, and a few other matters are under the direct jurisdiction of the empire, represented in the Reichstag, the Bundesrath and the Emperor.

The history of the development of forestry in Germany may be divided into periods variously. Bernhardt recognizes six periods; Schwappach makes four divisions, namely, the first, from the earliest times to the end of the Carlovingians (911) which is occupied mainly with the development of forest property conditions; the second, to the end of the Middle Ages (1500), during which the necessity of forest management begins to be sporadically recognized; the third, to the end of the 18th century, during which the foundation for the development of all branches of forestry is laid; the fourth, the modern period accomplishing the complete establishment of forestry methods in all parts of Germany. For the later historian it would be proper to recognize a 
fifth period from about 1863, when, by the establishment of experiment stations, a breaking away from the merely empiric basis to a more scientific foundation of forestry practice was begun.

For our purposes we shall be satisfied with division into three parts, namely: to the end of the middle ages, when with the discoveries of America and other new countries an enlargement of the world's horizon gave rise to a change of economic conditions; secondly to the end of the eighteenth century, when change of political and economic thought altered the relation of peoples and countries; thirdly the modern period, which exhibits the practical fruition of these changes.

\section{From Earliest Times to End of Middle Ages.}

Many of the present conditions, especially of ownership, and the march of progress in the development both of forest policy and forest management, can be understood only with some knowledge of the early history of the settlement of the country.*

As is well known, Aryan tribes from central Asia had more than a thousand years before Christ begun to overrun the country. These belonged to the Keltic (Celtic) or Gaelic race which had gradually come to occupy partly or wholly, France, Spain, northern Italy, the western part of Germany and the British Islands.

* FELIX DAHN, Urgeschichte der germanischen wnd romanischen Völker, 1887. 
These were followed by the Germani (supposedly a Celtic word meaning neighbor or brother), also Aryan tribes, who appeared at the Black Sea about 1000 B. C., in Switzerland and Belgium about 100 B. C. These were followed by the Slovenes, Slovaks, or Wends, crowding on behind, disputing and taking possession of the lands left free by or conquered from the Germani. Through these migrations the whole of Western Europe seems to have been fully peopled about $400 \mathrm{~A}$. D. by these tribes of hunters and herders. The mixture of the different elements of victors and vanquished led to differentiation into three classes of people, economically and politically speaking, namely the free, the unfree (serfs or slaves), and the freedmen, an important distinction in the development of property rights.

\section{Development of Property Conditions.}

The German tribes who remained conquerors were composed of the different groups of Franks, Saxons, Thuringians, Bajuvarians, Burgundians, etc., each composed of families aggregated into communal hordes with an elected Duke (dux, Herzog, Graf, Fürst), organized for war, each in itself a socialistic and economic organization known as Mark, owning a territory in common, the members or Markgenossen forming a republic. Outside of house, yard and garden, there was no private property; the land surrounding the settlement, known as Allmende, was owned in common but assigned in parcels to each family for field use, first changing from year to year, then becoming a fixed assignment. The outlying woods, known as the Marca or Grenzwald, forming dobatable ground with the neighboring tribes, was 
used in common for hunting, pasturing, fattening of hogs by the oak mast, etc., rather than for the wood. In return for the assignment of the fields, the free men, who alone were fully recognized citizens of the community, had to fulfil the duties of citizens and especially of war service.

Only gradually, by partition, immigration and uneven numerical development, was the original Mark or differentiation into family associations destroyed and a more heterogeneous association of neighbors substituted. At the same time inequality of ownership arose especially from the fact that those who owned a larger number of slares (the conquered race) had the adrantage in being able to clear and cultivate more readily new and rough forest ground. Those without slaves would seek assistance from those more favored, exchanging for rent or service their rights to the use of land; out of this relationship a certain vassalage and inequality of political rights developed.

Under the influence of Roman doctrine a new aspect regarding newly conquered territory developed. by which the Dukes as representatives of the community laid claim to all unseated or unappropriated land; they then distributed to their followers or donated to the newly established church portions of this land, so that by the year $900 \mathrm{~A}$. D., a complete change in property relations had been effected. In this way the large baronial estates of private owners came into existence which were of such great significance in the economic history of the Middle Ages, changing considerably the estate of the free men and changing the free mark societies into communities under the dominion of the barons. 
The first real king, who did not, however, assume the title, was Clovis, a Duke of the Franks, who had occupied the lower Rhine country. About 500 A. D., picking a quarrel with his neighbors, the Allemanni, he subdued them and aggrandized himself by taking their Mark. In this way he laid the foundation for a kingdom which he extended mainly to the westward by conquest, but also to the eastward, the warlike tribes of Saxons and other Germans conceding in a manner the leadership of the Franks.

A real kingdom, however, did not arise until Charlemagne in 772 became the ruler, extending his government far to the East.

At times the Kingdom was divided into the western Neustria, and the eastern Austria, and then again united, but it was only when the dynasty of Charlemagne became extinct with the death of Louis the Child (911), that the final separation from France was effected and Germany became a separate kingdom, the eastern tribes between the Rhine and Elbe choosing their own king, Conrad, Duke of Franconia. There were then five tribes or nations, each under its own Duke and its own laws, comprising this new kingdom, namely the Franks, Suabians, Bavarians, Saxons and Lorainers on the left bank of the Rhine, while the country East of the Elbe river was mostly occupied by Slovenians.

With Clovis began the new order of things signalized by the aggrandizement of kings, dukes and barons.

In addition to the rule regarding unseated lands there develops, also under Roman law doctrine, the conception of seignorial right, the power of the king to jurisdiction over his property. This right first claimed by 
the duke or king for himself is then transferred with the territory given to his friends and vassals, who thereby secure for themselves his powers and jurisdiction, immunity from taxes and from other duties as well as the right to exact taxes and services from others, the favored growing into independent knights and barons.

The forest, then, originally was communal property and the feeling of this ownership in common remains even to the present day. Indeed, actually it remained mostly so until the 13th century, although the changes noted had their origin in the 7th century when the kings began to assert their rights of princely superiority.

In these earlier ages the main use of the forests was for the hunt, the mast and the pasture, and since wood was relatively plentiful, forest destruction was the rule. Those who became possessed of larger properties through the causes mentioned tried to secure an increased value of their possessions by colonization, in which especially the slaves or serfs were utilized. These often became freedmen, paying rent in product or labor and acquiring the rights of usufruct in the property, out of which developed the so-called servitudes or rights of user, a limited right to use the property of another, the praedium of the Romans.

Through the development of private property there developed naturally also the right-which in our country we have not yet fully attained-of preventing the hunting on such lands, this being then their main use. This exclusive right to the chase or hunt we find recognized as a part of the property in the 8th century, when 
the kings forbade trespass under penalty of severe fines; the king's ban (interdiction) of 60 shillings being imposed upon the trespassers. Indeed, by the end of the 8th century the word Forst (voorst - foresta) which until then had been used merely to denote the king's property was exclusively used to designate any territory in which the hunt had been reserved, not necessarily woodland (the latter being referred to as silva or nemus).

This right to reserve the chase and the fishing, that is, to establish banforests was in the 10th century extended by the kings to territory not belonging to them, the chase being according to the Roman construction a regal right over any property. Under this conception fields and pastures, woods and waters, and villages with their inhabitants became "inforested" grounds. The Norman kings imbued with a passion for the chase exercised this right widely, especially in England, the forests of Dean, Epping and the New Forest being such inforested territorities, the inhabitants of which were placed under special "forest laws."

Presently the king's right of ban was granted with the land grants to his barons and to the clergy. Banforests also grew up through owners of properties placing themselves and their possessions under the protection of kings or bishops or other powerful barons and giving in exchange this hunting right, and in various other ways. At the same time the headmen of the Mark (Obermärker, Graf, Waldgraf), who from being elected offcers of the people had become officials of the king, began to exercise, by virtue of their office, the jurisdiction of the king and declaring the ban for their own or their friends' benefit, excluded the Markers from their an- 
cient right to hunt and fish freely over the territory of the Mark.

While in this way the freedom of the communal owners was undermined, the institution of banforests had nevertheless its value in that it led to forest protection, restriction in forest use and restriction in clearing, all, to be sure, merely for the benefit of the chase. Special officers to guard the rights of the king, forestarii, chosen from the free and freedmen, and also superior officers, forestmasters, were instituted, to adminster the chase and enforce the restrictions which went with it.

Gradually with the loss of property rights there came also a change in the political rights of the markers or commoners, the large barons interfering with their selfgorernment, assuming for themselves the position of Obermärker, appointing the officials, issuing strict forest ordinances to regulate the cutting of wood, and finally the original right which every commoner had of supplying himself with wood material, became dependent upon permission in each case and his title to ownership became doubtful.

Undoubtedly also through the influence of Roman institutions with which the Franks under their Merovingian kings came into close contact, there arose that social and political institution which became finally known as the feudal system. By the grants of lands which the kings made out of their own estates to their kinsmen and followers with the understanding that they would be faithful and render service to their masters, a peculiar relationship grew up, based on land tenure, the land so granted being called a fief or feud, and the relationship being called vassality or vassalage, denoting the personal 
tie between the grantor and grantee, the lord and the vassal; the lord with the obligation to defend the vassal and the vassal to be a faithful follower of his lord. Similar relationship arose from the surrender by landowners of their estates to the church or other powerful barons, to be received back again as fiefs and to be held by them as tenants in exchange for rent or service. In this way a complete organization of society developed in which, from the king down to the lowest landowner, all were bound together by obligation of service and defence, both the defence and service being regulated by the nature and extent of the fief. Finally all kinds of property, of whatever nature, as well as official positions which would give an income, were subject to be treated as fiefs. The obligations of the recipient were of various nature but finally service in army or court became the main one, giving rise to the class of knights (Ritter) or barons, while the fiefs to the small farmer gave rise to the class of peasants (Bauern, this name appearing first in 1106 under Conrad II).

'T'he fiefs of the higher class, while at first given only to the individual, became early hereditary, and hereditary succession to estates and offices generally became the rule. Primogeniture in the succession to the estates did not as in England prevail in Germany; either tenancy in common or equal division among the sons was practised. As a result the very many principalities came into existence in the 14 th and 15 th centuries, these growing smaller and smaller by subdivision. The first to institute the primogeniture rule by law was the house of Brandenburg (in the 15th century). 
In addition to the class of peasants and barons, there came into existence a third class, the burghers, when, by the order of Conrad I in the beginning of the 10th century, towns were built with walls and towers for defence against the encroachments of the Huns, who endangered the eastern frontier Mark. In order to encourage the settlement of these towns, any slave moving to town became a freeman; gifts of land, including forest areas were made to the cities, and the development of industries was encouraged in every way, the cities becoming free republics. These cities in the later quarrels of the kings with the lawless nobility were favored by the former and, having become rich and powerful gave loyal support with money and arms. In return for their loans the forest properties of the kings were often mortgaged to the burghers; and, failing of redemption, were often forfeited to them. In this way and through purchases the city forests came into existence.

Still other property conditions arose when, under Otto the Great (960), colonization of the eastern country beyond the Elbe was pushed. In these cases the Mark institution was absent, although the colonists did often become part owners in the king's forest, or acquired parts of it as common property, or else secured rights of user in the nearest royal forest.

By the end of the period, due to these various developments, a great variety of property conditions in forest areas had dereloped, most of which continue to the present time, namely royal properties, which by the end of the eighteenth century and the beginning of the nineteenth were in part to become state property ; princely and lordly possessions under separate jurisdiction, with or 
without entail, and mostly encumbered with rights of user; allodial possessions (held independent of rent or service) ; municipal possessions owned by city corporations; communal properties, the remnants of the Mark; and farmers' woodlots, resulting from partitions of the Mark.

All these changes from the original communal property conditions did not, of course, take place without friction, the opposition often taking shape in peasants' revolts; hundreds of thousands of these being killed in their attempts to preserve their commons, forests and waters free to all, to re-establish their liberty to hunt, fish and cut wood, and to abolish tithes, serfdom and duties.

\section{Forest Treatment.}

As stated, the German tribes which settled the country were herders and hunters, who developed into farmers, while the country was being settled. At first therefore, as far as the forest did not need to give way to farm lands, its main use was in the exercise of the chase and for pasture, and especially for the raising and fattening of hogs; the number of hogs which could be driven into a forest serving as an expression of the size of such a forest, and the oak and beech furnishing the mast were considered the preferable species. It is natural, therefore, that, wood being plentiful and the common property of all, the first regulation of forest use had reference to these, now minor benefits of forest property, as for instance the prohibition of cutting mast trees, which was enforced in early times. The first extensive regulation of forest use came from the exercise of 
the roval right of the ban and merely for the avowed purpose of protecting the chase.

Real forest management, however, did not exist, the forestarii mentioned in these early times being nothing but policemen guarding the rights of the kings or other owners of hunting rights. The conception that wood on the stump was of the same nature as other property and its removal theft had not yet become established: "quia non res possessa sed de ligno agitur" (wood not being a possessed thing), a conception which still pervades the laws of modern times.

The necessity of clearing farm lands for the growing population continued even in the western more densely populated sections into the 12 th and 13 th centuries. The cloisters were especially active in colonizing and making farm land with the use of axe and fire, such cloisters being often founded as mere land speculations. Squatters, as with us, were a frequent class of colonists, and in eastern Prussia continued even into the 17 th and 18th centuries to appropriate forest land without regard to property rights.

The disturbed ownership conditions, which we have traced, led also often to wasteful slashing, especially in the western territory, while colonization among the Slavs of the east led to similar results. In the 12 th century, however, appear here and there the first signs of greater necessity for regulating and restricting forest use in the Mark forest and for improvement in forest conditions with the purpose of insuring wood supplies.

In the 12 th century, division of the Mark forest begins for the alleged reason that individual ownership would lead to better management and less devastation. In the 
12 th and 13th centuries also, stricter order in the fellings and in forest use was insisted upon in many places. In the forest ordinances, which have always reference to limited localities, we find prescriptions like the following: The amount to be cut is to be limited to the exact needs of each family and the proper use of the wood is to be inspected; the timber is to be marked, must be cut in a given time and be removed at once; only dry wood is to be used for fuel and the place and time for gathering it is specially designated, similar to the present practice. The best oak and beech are to be preserved (this, however, with reference to the mast) and in the Alps we find already provisions to reserve larch and pine. The charcoal industry is favored (because of easier transportation) but permitted only under special precautions. Bark peeling and burning for potash is forbidden. The pasture is regulated with regard to the young growth, and sheep and goats are excluded.

Such measures are, to be sure, found only here and there where local conditions gave rise to a fear of timber famine and such communities may also be found making attempts to protect themselves by forbidding the export of wood from their territory (similar to our law forbidding export from the public timberlands in certain territories). An amusing restriction of this kind is found at Altenstadt where the bakers were forbidden to bake bread for any but the citizens of the town.

The first prohibition of clearings is found at Lorsch in the Rhenish country in $\mathbf{1 1 6 5}$, and other ordinances with such prohibition are on record in other parts in the 13th century. In 1237 at Salzburg clearings were prohibited in the interest of the salt mines, "so that the cut 


\section{First Plantings.}

forest may grow up to wood again," and in other parts where mining interests made a special demand for props or charcoal the regulation of forest use was begun early.

The difficulties of transportation in the absence of roads rendered local supply of more importance than at present and this accounts for the early measures to secure more economical use while distant woods were still plentiful but unarailable.

While in the 12 th and 13 th centuries a merely restrictive and regulative, ог else a let-alone policy, "allowing the wood to grow up," prevailed, we find in the 14th century the first beginnings of an attempt at forest extension.

In 1309 Henry VII ordered the reforestation of a certain stripped area by sowing. Of the execution of this order we have no record, but the first actually executed plantation on record is that by the city of Nuremberg in 1368 where several hundred acres of burned area were sowed with pine, spruce and fir; and there is also a record that in 1449 this crop was harrested. In 1420 the city of Frankfort on the Main followed this example, relying on the Nuremberg seed dealer, whose correspondence is extant and who was inrited to go to Frankfort, to give the necessary advice. He sowed densely in order to secure clear boles but expressed the opinion that the plants could not be transplanted and also relied on the phases of the moon for his operations.

The planting of hardwood seems to have been begun much later; the first reference to it coming from the cloister and city of Seligenstadt which agreed in 1491 to reforest annually 20 to 30 acres with oak. 
Natural regeneration by coppice was in quite general practice and satisfactory enough for fuelwood production. The system of coppice with standards was also frequently practised, the standards 20 or 30 to the acre being "reserved for the lord."

In the timber forest the unregulated selection system was continued generally through the period, although in 1454 we find in the Hartz Mountains a transition to a seed tree management, a few seed trees or groups of seed trees being left on the otherwise cleared area, somewhat in the manner of the French methode a tire-aire. Toward the end of the 15th century we find here and there a distinction made between timber forest, where no firewood is to be cut, and "leaf forest" which is to serve the latter purpose, and is to be treated as coppice.

Toward the end of the period we find also various provisions which are unquestionably dictated by the fear of a scarcity of timber. The discovery that pasture prevents natural regeneration led to a prohibition of pasturing in the newly cut felling areas. In 1488 we find already a diameter limit of 12 inches-just as is being advocated in the United States now-as a basis for conservative exploitation when the city of Brunswick is buying stumpage and in the contract is limited to this diameter and in addition obligated to leave 15 oaks or aspen per acre for seed trees.

Attempts of regulating the use of given forest areas by division into felling areas are recorded in 1359 by the city forest of Erfurt, when 286 acres were divided into seven felling areas. It is questionable whether this referred to a coppice with short rotation or whether a selection forest with seven periodic areas is meant. 
We see, then, that the first sporadic and, to be sure, crude beginnings of a forest management in Germany may be traced back to the 14 th and 15 th centuries; but it took at least 250 to 350 years before such management became general.

Outside of the information found scattered in forest ordinances, instructions and prescriptions of various kinds there is no forestry literature to be recorded from this period except one single book, published about the year 1300 by an Italian, Petrus deCrescentiis, which was translated into German. It was merely a scholastic compilation on agriculture and allied subjects, mostly cribbed from old Roman writers and without value for German conditions.

II. First Development of Forestry Methods.

(Period 1500 to 1800 .)

The period following the middle ages marks the gradual changes from the feudal system to the modern State organizations. Various causes which led to an increased development of industrial life were also instrumental in hastening the progress of forest destruction. At the same time during this period the germs and embryonic beginnings of every branch of forestry, real forestry policy, forestry practice and forestry science are to be noted. By the end of this period preparatory for more modern conditions we find organized technical forest administrations, well developed methods of silviculture and systems of forest management. 
1. Development of Forest Property Conditions.

A number of changes in the conceptions of political relations, in methods of life and of political economy brought further changes in property conditions on the same lines as those prevailing in the 14th and 15th centuries. These changes were especially influenced by the spread of Roman law doctrine regarding the rights of the governing classes; by the growth of the cities, favoring industrial development and changing methods of life; by the change from barter to money management, favored by the discovery of America and other world movements and by the resulting changes in economic theory.

Through the discovery of the new world an influx of gold and silver gave impetus to industry and commerce of the cities; the rapid increase of money capital increased extravagance and induced a desire for amassing wealth, which changed modes of life, changed policies and systems of political economy.

The fiscal policy of the many little principalities was dominated by a desire to get a good balance of trade by fostering exports of manufactures, but forbidding exports of raw materials like forest products, also by forbidding imports, subsidizing industries, fixing prices by law, and taking in general an inimical attitude towards outsiders.

This so-called mercantilistic system, which had also full sway in England under Cromwell and in France under Colbert's influence, and the fiscal policy which was bent upon bringing cash into the country, led under the direction of servile officials to oppressive measures. 
A reaction naturally followed, when it was pointed out that the wealth of a nation lies in its natural resources and in its labor, but this so-called physiocratic doctrine had little practical influence except to prepare men's minds for the reception of the teachings of Adam Smith at the end of the period.

The doctrines of the Roman law, deified by the jurists and commentators, undermined the national conceptions and institutions of free citizenship and property relations; courts, legislation and administration were subject to their sway, and this influence lasted, in spite of reactions, until the end of the 18 th century. Under it the doctrine of the imperium-the seignorage or superior power of the princes (Hoheitsrecht) -was further dereloped into the dominium terrae, i. e., superior ownership of all the land, which gives rise to the title and the exercise of the function of "Landesherren," masters of the land and confers the privilege of curtailing and even discontinuing private property rights.

Cnder this doctrine the historic position of the Mark is perrerted and instead of being the common property of the people, it becomes the property of the prince, on which he graciously permits the usufruct; for forest, pasture and water (Wald, Weide, Wasser) are res publicae, hence ownerless and at the disposal of the King. Through this construction of relationship, as well as through the same machinations and tricks which the princes as Obermaerker or headmen of the Mark employed in the foregoing period to usurp power, and partly through voluntary dissolution the decadence of the sacial, economic and political organization of the Mark was gradually completed. 
The original usufruct of a common property was explained in the Roman sense as a precarium or servitude, and from being a right of the whole organization became a right of the single individual or group of individuals. In this way the socialistic basis of the Mark was destroyed. Through the exercise of the Forsthoheit, the appointment of the officials instead of their election, issuance of ordinances and the usurpation of the legislative and police power, the political power of the Mark is broken and the 'Thirty Years' War completes the breakdown; the pride of the burgher and the peasant is gone, their autonomy destroyed and their economic political organizations sink into mere corporations based on land tenure, which, according to Roman doctrine, come under the regulation of the State or prince.

The nobility move into the cities and leave the administration of their estates to officials who are constantly pressed to furnish the means for the extravagant life of their masters. These in turn harass and oppress the peasantry, who finally become bondsmen, Gutshörige (bound to the glebe) and lose their independence entirely.

Reforms in this situation of the peasantry began first in Prussia in 1702, when bondage was abolished for all those who could purchase their houses and farms from the gentry. As few had the means to do so, the result was the creation of a proletariat, hitherto unknown because under the old feudal system the lord had to feed his impoverished bondsmen.

Changes in forest property in particular were brought about by the increase of princely property through the 
various methods of exercising the seignorage. Especially after the Thirty Years' War ownerless tracts falling under this right were plentiful. In addition, wherever waste lands grew up to wood, they were claimed by the princes:

"Wenn das Holz dem Ritter reicht an den Sporn Hat der Bauer sein Recht verlorn."

Some additions came from the secularization of church and cloister property, and others by the slices which the princes as Obermärker secured from the Mark forests by various artifices.

It is these properties, which in Prussia were turned over to the State by the King in 1713 , and by other princes, not until the 19th century.

The same means which the princes employed, were used by the landed gentry to increase their holdings especially at the expense of the Mark from which in their capacity of Obermärker they secured slices by force or intrigue.

The peasants' forest property-the Mark forest-had by the 19 th century been almost entirely dismembered, part having come into the hands of the princes, part having been divided among the Märker and part having become corporation forest in the modern sense.

Partition had become desirable when the restrictions of use which were ordered for the good of the forest became unendurable under the rigid rule of appointed officials, but the expected improvement in management which was looked for from partition and private ownership was never realized.

After the Thirty Years' War the free cities were impoverished and their autonomy undermined by Roman 
doctrine. From free republics they become mere corporations under the supervision of appointed officials, and experience decadence in political as well as material directions. Hence, no increase in city forest took place except through division of the Mark forest in which cities had been co-owners, and through secularized properties of cloisters.

The worst feature, from the standpoint of forest treatment, which resulted from these changes in property conditions and relationship, was the growth of the pernicious servitudes or rights of user, which were either conferred to propitiate the powerless but dangerous peasantry or evolved out of the feudal relations. From the 16th to the 19th centuries these servitudes grew to such an extent that in almost every forest some one outside of the owner had the right to use parts of it, either the pasture, or the litter or certain classes or sizes of wood.

These rights have proved the greatest impediment to the progress of forestry until most recent times, and only within the last few decades have the majority of them been extinguished by legal process or compromise.

2. Forest Conditions.

Under the exercise of these various rights and the uncertainty of property conditions, the forest conditions naturally deteriorated continuously until the end of the 18th century; the virgin woods were culled of their wealth and then grew up to brush, as is usual in the United States.

Every forest ordinance began with complaints regariing the increasing forest devastation and predicted 
timber famine in view of the increasing population, increasing industry and commerce, and hence increased wood consumption. Especially along the water routes, which furnished the means of transportation, the available supplies were ruthlessly exploited. More serious enemies than the exploitation of the timber proved the pasturing of cattle, the removal of the litter, and above all the fires.

Towards the end of the 16th century ordinances against forest fires began to be enacted, but as late as 1778 the necessity of keeping the rides or fire lanes open in the forests of Eastern Prussia is justified by the statement that "otherwise the still constantly recurring fires could not be checked," that "not a single acre of forest could be found in the province that had not been burnt in former or later times," and that "the people are still too much accustomed to the ruthless use of fires, so that no punishment can stop them."

Other causes of devastation were the Thirty Years' War, the wars of the 18th century, and the loss of interest in the forest by the peasants after the collapse of the Mark. These had often to steal what they needed, and their depredations were increased by the desire to revenge themselves on the landed proprietors for the oppressions to which they were subjected. The increase in game, which was fostered by the landed gentry, did much damage to the young growths, and the increase in the living expenses of the nobility who mostly abandoned country for town had to be met by increased exploitation.

By the end of the middle ages the reduction of forest area had proceeded so far that it was generally believed 
desirable to restrict the making of clearings to exceptional necessities, except in the northeastern parts and in the distant mountain districts.

Yet a growing population increased the need for farm land, and since intensive use of the existing farm area was not attempted until the end of the 18th century, the forest had to yield still further.

3. Methods of Restriction in Forest Use.

All ordinances issued by the princes to regulate the management of their properties contain the prescription, that permission of the Landesherr is necessary for clearings, and that abandoned fields growing up to wood were to be kept as woodland, this partly for timber needs, partly for considerations of the chase. Still, Frederick the Great in colonizing East Prussia, expressed himself to the effect that he cared more for men than for wood, and enjoined his officials especially to colonize the woods far from water, which entailed even more waste of wood than where transportation to market allowed at least partial marketing.

Improvident clearings proceeded even under his reign on the Frische Nehrung between Danzig and Pillau, starting the shifting sands of that peninsular.

In the absence of all knowledge as regards the extent of existing supplies or of the increment, and with poor means of transportation, at least local distress was imminent.

To stave off a threatening timber scarcity, regulation in the use of wood was attempted by the forest ordinances, even to the extent of forbidding the hanging out of green brush to designate a drinking hall, and the cut- 
ting of May trees, similar to our crusade against the use of Christmas trees. A diameter limit to which trees might be permitted to be cut, was also frequently urged. Regulation of forest use did not confine itself to the princely properties alone, but, in the interest of the whole, the restrictions were extended to all owners. These restrictions were directed either to the practice in the exploitation of the forest or to the use of the material. In the latter direction the attempts at reducing the consumption of building timber are of special interest. Building inspectors were to approve building plans and inspect buildings to see that they were most economically constructed; that repairs were made promptly, to aroid the necessity of more extensive ones; that new buildings replacing old ones were not built higher than the old ones. In Saxony, as early as 1560 , it was ordered that the whole house must be built of stone, while elsewhere, the building of stone base walls and the use of brick roofs instead of shingles was insisted upon.

Even the number of houses in any community was restricted. Fences were to be supplanted by hedges and ditches.

Economies in charcoal burning, in potash manufacture for glass and in the turpentine industry were prescribed, and about 1600, the burning of potash for fertilizer was forbidden entirely, but these laws proved unavailing. Even in fuel-wood a saving was to be effected by using only the poorer woods and windfalls, by instituting public bake ovens (still in use in Westphalia), by improving stoves, restricting the number of bathing rooms, etc. 
The consumption of fuel wood seems to have been enormous, for we find record of 200 cords used by one family in a year and of 1,200 cords or more used by the Court at Weimar during the same time.

The substitution of turf and coal for firewood was ordered in 1697 and $177 \%$ respectively, but only since 1780 did coal come in as a surrogate. Tanbark peeling was also forbidden and only the bark of trees soon to be felled or of stocks was to be used. For cooperage only the top-dry oak was to be used; for coffins anly softwood, or according to Joseph II of Austria, no wood, but black cloth was to be used.

Especially the use of oak was restricted, even as early as 1562 , in some parts of the country.

For regulating the practice in the forest the restrictions took often only the general form of forbidding devastation, without specifying what that meant.

Then, besides the diameter limit and the regulation of pasture to protect young growths, excluding sheep and goats entirely, an attempt was made to secure at least orderly procedure in the fellings. Foresters were to designate what was to be cut even for firewood. Marking irons and hammers were employed for this purpose by the middle of the 15th century (usually two markings, by forester and by inspector to check).

And this designation by officials extended even into the private forest where finally no felling was allowed without previous permission and designation by a forester.

The use of the litter by the small farmers had grown to excess in these times and it was thought desirable to stop it, but this aid to the poor peasant was so necessary 
that only regulations in the gathering of it could be insisted npon.

\section{Forest Policy.}

With the beginning of the 18 th century besides prescriptions against wasteful use, definite forest policies had become quite general, with a view to forest preservation and improvement of forest conditions, and also to providing wood at moderate prices.

Even the reboisement of torrents had been recognized as a proper public measure in Austria in 1788, although active work in that direction was not begun until nearly a century later.

The rise of prices during the 17th and 18th centuries had been very considerable, doubling, trebling and even quadrupling in the first half of the 18 th century. The mercantilistic doctrines of the time led, therefore, to attempts to keep prices low by prescribing rates for wood and by restricting and regulating wood commerce.

This was done especially by interdicting sale to outsiders, forbidding export from the small territory of the particular prince, or, at least, the inhabitants of the territory were to have a prior right and cheaper rate.

Owing to the small size of the very many principalities, the free development of trade was considerably hampered by these regulations. Sometimes also wood imports were prohibited, for instance, when in Würtemberg (1740) widespread windfalls had occurred which had to be worked up.

Wood depots under government control were established in large cities and the amount of wood to be used per capita prescribed, as in Koenigsberg (1702). 
In Berlin, in 1766, a monopoly of the fuel wood market was rented to a corporation, excluding all others except by permission of the company. This was in 1785 supplanted by government administration.

Another such monopoly was created in the "Nutzholzhandelsgesellschaft" (Workwood sales agency) for the export trade of building materials from Kurmark and Magdeburg, which had prior right of purchase to all timber cut, the idea being to provide cheap material for the industries. This, too, came into the hands of the State in $17 \% 1$.

In Prussia, to prevent overcharges, the Jews were excluded from the wood trade in 1761 .

The exercise of the Forsthoheit (princely supervision), originating in the ban forests, favored by the mercantilistic and absolutist ideas of the 17 th and 18 th centuries, gradually grew until the end of the 18th century to such an extent that the forest owners themselves were not allowed to cut a tree without sanction of some forest official, and could not sell any wood without permission, even down to hop-poles, although the large landed property owners vigorously resisted this assumption of supervisory powers. Much discussion and argument regarding the origin of this right to supervision was carried on by the jurists upon the basis of Roman law doctrine, and it was proved by them to be of ancient date. The degree, however, to which this supervision was developed varied considerably in the different parts of the empire, according to different economic conditions. The interference and protection of forests appeared more necessary, where advanced civilization and denser population created greater need for it. We find therefore that the restrictive policy was much more developed in the Southern 
and Western territories than in the Northern and Eastern ones, where the development begins two hundred years later.

The oldest attempts of controlling private forest property are found in Bavaria (1516), Brunswick (1590) and Würtemberg (1614). Here forest properties were placed either entirely under the supervision of the princely forest adminstration, or, at least, permission for intended fellings had to be secured. Later these restrictions were considerably reduced in rigor (Bavaria, 1789).

In Prussia private forest property remained free from government interference well into the 18th century. An edict by the Great Elector in 1670 merely inveighs against the devastation of forests by their owners but refrains from any interference, and the Forstordnung of 1720 also contained only the general injunction to the owners not to treat their forests uneconomically. But in 1766 Frederick the Great instituted a rigid supervision providing punishment for fellings beyond a special budget determined by experts.

Church and cloister property had always been severely supervised, similar to the Mark and other communal forest property under the direction either of specially appointed officials or the officials of the princes. Finally, in some parts (Hesse-Kassel, 1711; Baden, 1787), the entire management of these communal forests was undertaken by the government.

In Prussia, by the Order of 1754, the foresters of the State were charged with the supervision of the communal forests, in which they were to designate the trees to be felled and the cultures to be- executed; but as there was 
no pay connected with this additional duty and the districts were too large, the execution of this supervision was but indifferently performed.

In 1749 a special city forest order placed the city forests in Prussia under the provincial governments, requiring for their management the employment of a forester and the inspection of his work by the provincial forestmaster.

\section{Personnel.}

Although all this supervision was probably more or less lax, the possibility of more general and incisive influence was increasing because the personnel to whom such supervision could be intrusted was at last coming into existence.

The men in whose hands lay at the beginning of the 18 th century the task of developing and executing forest policies and of developing forestry practice came from two very different classes. The work in the woods fell naturally to the share of the huntsmen and forest guards, who by their practical life in the woods had secured some wood lore and developed some technical detail upon the basis of empiric. These so-called holzgerechte Jaeger (Woodcrafty hunters) prepared for their duties by placing themselves under the direction of an established huntsman, who taught them what he knew about the rules of the chase, while by questioning woodchoppers, colliers, etc., and by their own observation the knowledge of woodcraft was acquired.

At the head of affairs stood the so-called cameralists or chamber officials, men who had prepared themselves by the study of philosophy, law, diplomacy and political 


\section{Personnel.}

economy for the positions of directors of finance and State administration. Rather ignorant of natural science and without practical forestry knowledge, their efforts' were not always well directed. They deserve credit, however, for having collected into encyclopædic volumes the empiric knowledge of the practitioners or Holz: gerechten and for having elaborated it more or less successfully. In this work they were joined by some of the professors of cameralia and law at the universities.

By the middle of the 18th century the hunters had so far grown in knowledge and education as to be able to produce their knowledge in books of their own.

Quite a literature developed full of acrimonious warfare of opinions as is the rule where empiricism rules supreme.

Notable progress, however, came only when hunting was placed in the background and more or less divorced from forest work.

\section{Development of Silviculture.}

In addition to the restrictive measures and attempts at mere conservative lumbering without much thought of reproduction, there were as early as the 16 th century silvicultural methods applied to secure or foster reproduction.

Owing to differences in local conditions and difference in necessities, this development varied greatly in time, the Western and Middle country practicing as early as the 16th century what in the Eastern country did not appear until the 18th century. The forest ordinances from which we derive our knowledge prescribed, to be 
sure, many things that probably were not really put into practice.

a. Natural regeneration was at first merely favored, without the adoption of any very positive measures to secure it, namely, by removing the brush so as not to smother the young growth, by keeping out cattle from the young growth (Schonung), by removing the cut wood within the year, so as to give young growth a chance for establishing itself.

If the selection method of lumbering did not produce any desirable result in reproduction, the clear cutting which was practiced without system where charcoal manufacturing or river driving invited to it, did even less so. In either case, besides the defective and damaged old stubs which were left in the lumbering, a poor aftergrowth of undesirable character remained, as is the case with us on so many areas.

As early as 1524 and 1529 we have record of a conscious attempt to secure a reproduction by leaving ten to thirty seed trees per acre; but the result was disappointing, for this practice, being applied to the shallowrooted spruce, the inevitable occurred, namely, the seed trees were thrown by the winds.

This experience led to the prescription (in 1565) to leave, besides seed trees, parts of the other stand for protection against wind damage; later, wind protection was sought by leaving parcels standing on all four sides, giving rise to a checker-board progress of fellings or a group system of reproduction, which by the middle of the 18th century had developed into the regular strip system, being applied in Austria (1766) to fir and sprice 
and in Prussia (1764) to pine. And this marginal seeding method remained for a long time the favorite method for the conifers.

To avoid long strips and distribute the fellings more conveniently, $\nabla$. Berlepsch (in Kassel) recommended (in 1760) the cutting in echelons (curtain method, Koulissenhieb), which insured better seeding, but increased danger from windfall and was never much practiced, the disadvantages of the method being shown up especially in the Prussian Forest Order of 1788.

In the first half of the 18th century it was recognized that the wind danger would be considerably reduced by making the fellings progress from East or Northeast to West; the conception of a regular properly located felling series being first elaborated in 1745 by von Langen in the Harz mountains, who also accentuated the necessity of preserving a wind mantle on exposed situations. Both of these propositions reappear in the Prussian Order of 1780 , according to which the fellings are to proceed in a breadth of twenty to thirty-five rods from East to West.

The application of a nursetree method for conifers was proposed in 1787 by $\nabla$. Burgsdorf (Prussia), a dark position (Dunkelschlag) and a regeneration period of seven years being adrocated.

In broadleaved forest, besides the selection forest, the natural result of the sprouting capacity of the hardwood had led to a coppice method which was extensively relied upon for fuel production. This was rarely, however, a simple coppice, for intentionally or unintentionally some seedlings or sprouts would be allowed to grow on, leading to a composite forest and finally to a regular coppice 
with standards (1569, etc.), with an intentional holding over of the valuable oak and ash for standards. Probably, however, large areas of unconsciously produced composite forest exhibited sad pictures of branchy overwood with suppressed underwood of poor sprouts, injured by game and cattle-a scrubby growth, into which crept softwoods of birch and aspen. Attempts at pruning such scrub growths into shape on quite an extensive scale are on record.

The recognition that more wood per acre could be secured by lengthening the rotation of the coppice, which seems to have been mostly twelve years or less, led to twenty and thirty year turns and finally to fifty, sixty and even eighty year rotations or so-called polewood management, (Brunswick, 1745), also called Hochwald (high forest).

A full description and working plan for such a forest to be managed in eighty year rotation, the city forest of Mainz in the Odenwald and Spessart mountains, dates from 1773 , and this polewood forest management became quite general after the middle of the 18th century, but in the last half of the 19th century was generally replaced by the true high forest management under nursetrees, the experiences with the natural reproduction of conifer forest having proved the advantages of this method.

The primitive beginnings of this so-called Femelschlag method (Compartment selection or shelterwood method) are found in 1720 and 1730 in Hesse Darmstadt, where Oberforstmeister von Minnigerode prescribed regular fellings progressing from north to south, removing all material down to polewood size (in selec- 
tion or virgin forest), excepting a number of clean boles, one every ten to twelve paces being left for seed and nursetrees. The good results in reproduction stimulated owners of adjoining estates to imitate the method (1737).

The observation that in beech forest the young crop needed protection and succeeded better when gradually freed from the shade of the seed trees, especially on south and west aspects where drought, frost and weeds are apt to injure it on sudden exposure, led to the elaboration of the principle of successive fellings.

In the ordinance of Hanau as early as 1736 three grades of fellings were developed, the cutting for seed, the cutting for light, which was to begin when the young crop was knee-high, and the remoral cutting when manhigh.

This method spread rapidly and was further developed by the addition (in 1.67) of a preparatory cutting, to secure a desirable seedbed, and by lengthening the period of regeneration and elaborating other detail, so that by 1790 the principles of natural regeneration under nursetrees for beech forest were fully developed in Western Germany.

In other parts hardwood forest management was but little developed. The Prussian Forest Ordinance of $\mathbf{1 7 8 6}$ contented itself with forbidding the selection method, but declaring natural regeneration, as practiced in the pineries, not applicable; while the Austrian Ordinance of 1786 recognizes only clearing followed by planting as the general rule.

b. Artificial Reforestation. Although sporadic attempts at sowing and planting are on record as early as 
the beginning of the 14th century, extensive artificial reforestation did not begin until the middle of the 18th century, by which time planting methods were quite fully developed.

Among the hardwoods, the oak was the first to receive special attention. By the middle of the 16 th century the forest ordinances gave quite explicit instructions for planting oak in the so-called Hutewald, a combination of pasture and tree growth such as is found to-day in the bluegrass region of Kentucky; the remnants of these poor pasture woods with their gnarly oaks have lasted into modern times.

In the forest ordinance of Brunswick (1598) orders are given to plant on felling areas: "every full farmer shall every year at the proper time set out ten young oaks, every half farmer five, every farm laborer three, well taken up with roots (wildlings), and plant them in the commons or openings at Martini (November) or Mitfasten (Easter) and cover them with thorn brush" (to protect them against cattle).

About that time it was, indeed, incumbent on every marker to sow annually five oaks, or plant several young seedlings for every tree cut and to tend them a few years; and the custom existed in the low country, (afterwards (1700) introduced by law in Saxony) to plant in celebration of certain occurrences-a kind of arborday-especially to celebrate the marriage day; in order to be married the bridegroom had to prove that he had planted a certain number of oaks, which in Prussia (1719) had to be six, besides six fruit trees. The existence of this custom, now long forgotten, has given rise in the United States to the story that this is the method by which the German forest is maintained. 
The method of collecting and keeping acorns over winter was well known in 1579, as is evidenced by the Hohenlohe Forest Ordinance, which advised fall sowing, but, if that did not prove successful, to prepare the ground in summer, leave it through the winter and sow in the spring.

While in earlier times sowing seems to have had the preference, at a later period planting was practiced, at first with wildlings, but as early as 1603 we find mention of oak nurseries.

The Prussian Order of 1720 ordered the foresters to plant oaks in the openings before Christmas, for which they were to be paid, if the trees were found alive after three years. The growing and culture of oak also interested Frederick the Great, who ordered its extension everywhere. Very explicit and correct rules for growing and transplanting them, and some to which we would not subscribe, were given in the books of the 18th century. Among the planting methods we find in 1719 and again in $17 \% 6$ one similar to the Manteuffel method of planting in mounds.

While oak culture was especially fostered in Northwestern Germany, the cultivation of conifers first received attention in the southwest, and in the same manner which was inaugurated by the Nuremberg seed dealer in 1368. A new idea, introduced in the Palatine Forest Ordinance (1565) and in the Bavarian Forest Ordinance (1568), was the prescription, to soak the seed before use and sow mixed with sawdust or sand, bringing the seed under with brush or iron rakes.

Carlowitz (1713) taught well the methods of collecting, extracting and keeping the seed, and even proposes 
seed tests; the seedbeds are to be made as for carrots, dense sowings are to be thinned and the thinnings transplanted into nursery rows, the seedbeds to be covered with moss and litter to protect them against heaving; the question of cost he also discusses. The adaptation of plant material to different sites-conifers where oaks are not suitable-was also understood (Bavarian Forest Ordinance, 1683).

As long as the old method of extracting the seed in hot stoves or ovens prevailed, conifer sowings gave but indifferent results.

In the pine forests of Prussia during the second half of the 18th century the method of sowing the cones on large waste and sand barrens where the sun would make them release the seed was practised, and before Bremontier had written his celebrated mémoire sur les dunes, sanddunes had been recovered with pine plantations in Germany in the manner which is still in vogue.

The planting of conifers came into practice much later and then it was mostly done with wildlings. Opinions differing as to the value of sowing or planting, it was erroneously held until the 19th century that planting was less successful and too costly in comparison with the small harvest yield, which necessitated cheapness of operations. It was only towards the end of the 18th century that planting of pine was resorted to, but merely for repairing fail places in sowings and natural regenertion, and then with a ball of earth (1779), using a hollow spade,- - costly method. The cost of a certain plantation in 1751 is reported as less than $\$ 3.00$ per M., in 1770 as low as 70 cents per M. To cheapen the operations the labor was exchanged for wood, pasture or other materials or advantages. 
In Prussia, in 1773, all recipients of free wood had to do service in the cultures; in 1785 every farmer had to furnish a certain amount of cones or acorns. The method, lately adopted in Russia, came into vogue in Prussia in 1719 , namely, of charging, besides the value of the wood, a toll to be paid into the planting fund (about $\% \%$ of the value), which method was also imitated elsewhere.

The use of the Waldfeldbau (combined farm and forest culture) was also inaugurated for the purpose of cheapening the cost of plantations (by $\therefore$ Langen in 1744) when the great movement for reforesting wastes and openings began, the tree seed beins sown with the grain either at once or after farm use for some vears.

Regular annual planting budget: (of $\$ 50-\$ 100-$ $\$ 200$ ) were inaugurated in Brusiswick by $\nabla$. Langen in 1745 , and in 1781 the Prussian forest administration had attained to entirely modern planting plans and annual planting budgets.

It was no wonder that the fear of a timber famine and the apparent hopelessness of bringing improvement into the existing forest conditions created anxiety and a desire to plant rapid growers, such as birch, willow, aspen, alder; the planting of the White Birch became so general in the beginning of the 18 th century that a regular betulomania is recorded.

At that time, to be sure, firewood was still the main concern, and these rapid growing species had some justification. But where birch was mixed in spruce plantations its baneful effects consisting in whipping off the spruce tips and injuring its neighbors were soon recognized and much trouble was occasioned in getting rid of the unwelcome addition. 
The Robinia, which had been brought from America in 1638 was also one of those recommended in the middle of the 18th century and was much planted until Hartig pointed out that the expectations from it were entirely misplaced.

Of course no building material could be expected from these species, hence the larch, also a rapid grower, was transplanted from the Alps (1730 in Harz mountains) and its use was extended as with us to comditions for which it was not adapted.

It was principally a desire for novelty and perhaps for better, especially foreign things, that North American species were much planted in parks during the first half of the 18th century, but, although F. A. J. von Wangenheim's very competent writings on the American forestflora and on the laws of naturalization (1787) stimulated interest in that direction, with the single exception of the White Pine ( $P$. Strobus), of which large numbers were planted, the use of American species for forest planting was not inaugurated till nearly 100 years later.

\section{\%. Improvement of the Crop.}

Thinning of stands had been practiced early in the 16th century, not for improvement of the remaining stand so much as to secure fence material, although in 1531 the observation was already recorded that thinning improved and stimulated the remaining growth.

In the 17 th century opposite views, or, at least doubts, were expressed in the forest orders, and sometimes thinning was forbidden. Even in the 18th century some of the prominent foresters, Doebel and Beckman, were opposed to it, and although others favored the operation, the practice of it remained limited. 
In 1761 we find the first good statement of the theory of thinnings by Berlepsch, who advised taking out the suppressed trees when the sound poles were clear of lower and middle branches; he also accentuated the financial argument of earlier returns and increased value of the remainder.

About the same time Zanthier recommended two thinnings, namely, for conifers in the thirtieth to fortieth year first and again in the fiftieth year, for broadleaf forest first in the forty-fifth and again in the eightieth to ninetieth year.

In 1765 the financial gain from thinnings is figured by Oettelt, and the possible reduction of the rotation due to thinnings is recognized by Leubert in 1774 .

Just as the thinning in polewoods arose from the need of utilization, so the weeding of young growths was done for the purpose of getting material for withes to bind the grain, ete.

The removal of coppice shoots in oak plantings was practiced in Prussia in 1719, and the thinning of too dense sowings was advised by Carlowitz in 1713. Yet much later even such an intelligent man as Oettelt inveighed against the weeding out of the birch in spruce sowings because "nature prefers variety, with which preference it is not good to interfere."

This was in opposition to $\nabla$. Langen (1745), who prescribed for the first time regular cleaning or weeding. especially the removal of the softwoods, aspen and birch, and of coppice shoots from seedling forest.

It was also known that this weeding is best done "in the full sap," in order to kill the stocks. 


\section{Methods of Regulating Forest Management.}

Organized forest management was slower to develop than silvicultural methods. The first attempts to bring order into the progress of fellings took the form of dividing the whole area into a certain number of felling areas $(12,16,20,30$, etc.), several ordinances containing prescriptions to that effect dating from the middle of the 15 th and 17 th centuries.

It is doubtful whether the numbers of these areas indicate years of rotation, in which case they could only have applied to coppice, or whether they indicate periods of return in selection forest, although the historians seem to jump to the former conclusion. The area division practiced by $\nabla$. Langen in the Harz mountains (1745), who prescribed the division of larger districts into fifty to sixty, of smaller districts into twenty to thirty felling areas, also leaves it doubtful, whether the areas corresponded to an assumed rotation or to a period of return.

At first the division was not into equal areas, for no survey existed, and its object was simply to localize the cutting and provide orderly progress. The subdivision was made in the mountain country by following the topography, valleys and ridges, while in the plain the lines opened up for purposes of the chase (to set up nets), called Schneisen or Gestelle (rides), bounding square areas called Jagen, Quadrat, Stallung, were used for the limitation of the felling areas. Most commonly, however, largely due to absence of surveys, the ordered division did not materialize, but existed only on paper.

With more exact measuring of areas and with the conception of rotation or longer periods of return, it was recognized that the inequality of the sites or soil quality, 
especially in mountain districts, produced very unequal felling budgets. To overcome this inequality, Jacobi, in Goettingen (1741) introduced proportional felling areas, making the felling areas on poor sites permanently larger.

Similarly, v. Langen and Zanthier attempt equal annual returns, without slavishly holding to the geometric division, only seeing to it that the total area be cut over in the predetermined rotation.

The first attempts to introduce a regulated management by making a volume division the basis is recorded in the Harz mouittains in 154\%. This method based on very crude estimates, although upon very fair forest description, was continued into the 18 th century.

In the last half of the 18th century all these crude methods were improved and applied on extensive areas.

In 1785 Zanthier combined area and volume division, determining the felling budget on each felling area by counting and estimating the trees and calculating how many trees could be used annually under a sustained yield management; the area division being used only as a check or means of control.

A very considerable advance was made by $\mathrm{O}$ - tait, (who surveyed and regulated the Weimar for sta in 1.60) in the elaboration of details and establis:ment $\mathrm{ti}$ proper principles for regulating the felling linget.

In his forest description he introduces for t.: trs time periodic age classes, usually six, but of nerer. length: Young growth below twelre yea , wit thei tw the to twenty-four years, polewood twe $\ldots$ in if wr: years, clear timber forty to fifty, me $\ldots 1+\cdots$. mince ifty

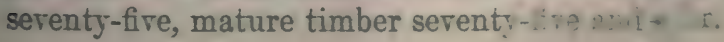


He divides into proportional areas (which were marked by stones in the woods) equalizing them according to age, quality, accretion, soil, exposure, so as to secure equal annual budgets; the stands were ranged into seven or eight unequal age classes and each into as many annual felling areas as there are years in the age class; if some of the age classes were absent, he cut in the older class until the younger had grown to the proper age and by varying the cut from good to poor sites or stands he tried to even out the budgets. The volume budget he determined by average accretion measurements. This method was however much too far advanced and required too much mathematics to find imitators at that time.

Another method which proved also too complex for the foresters of the time was that of v. Wedell; nevertheless, by 1790 he had put into working order 800,000 acres in Silesia. He divided this area into districts, the districts into blocks or management classes and used an elaborated proportional area division for determining the felling budget. He distinguished quality of stand and quality of site and made four site classes. The volume of stock he found by means of sample areas, to which he added the accretion in order to find the total volume for harvest, when it could be determined how .ng with a given budget the stands would last, or what uvcrage annual felling budget could be taken before the bext age-class would be mature.

In the North German plain with very uniform conditi. ns of snil and timber the method of equal felling areas was inat natural and most easily applied.

Frede-jus the Great, who took a considerable interest in forest, matters, ordered such an area division in 
1740 , fixing upon different numbers of felling areas, but finally, in $17 \% 0$, deciding on a rotation of seventy years. Lack of personnel prevented much progress of this regulation until in 1778 จ. Kropf undertook the direction of the forest survey and regulation, when a more regular progress may be noted. Not agreeing with his master regarding the short rotation of seventy years, he arranged to have each district divided into two working blocks, and by cutting alternately in these, managed to double that rotation. His successor, Hennert, in 1788 devised a new method by introducing allotment of a number of annual felling areas to a period of the rotation when at least the periodic budget could be equalized. A value or money yield equalization of the felling budgets was also attempted.

For easier handling the forest was divided into small compartments or Jagen and a classification of four, still uneven, periodic age classes (of different length for conifers and broadleaved forest), and three site qualities were employed. The merchantable stock was ascertained by a sample area method and the felling budget by dividing the oldest age class by the number of years it must last until the next was ready. Since no attempt was made to secure a proper age class gradation, the method failed to improve conditions for the next rotation.

Some 500,000 acres were regulated according to this plan, probably very superficially.

In 1789 Bavaria also ordered a division into annual felling areas.

In all these methods of regulating the yield or budget the area played the main role, the volume being only a secondary consideration. 
The first elaboration of a pure volume division was made by Beckman in 1759, who estimated stock on hand by trees and guessed more or less at the accretion, allowing $2.5,2$ and $1 \%$ for the different sites and then made a year to year calculation of stock for 125 years. How the felling budget was finally determined is not known.

Two methods were simultaneously devised in 1783 which form the transition to the so-called allotment methods, making periodic age classes of an equal number of years and allotting either felling areas or volumes to each period of the rotation. Incapacity of the officials in Würtemberg prevented the application of the one method, while the other, devised by Maurer, remained also only a proposition.

But in 1788 Kregting in his Mathematical Contributions to forestry science teaches a pure volume allotment method with ten year age classes and nearly all the apparatus which was afterward developed by Hartig, who in the next period dominated to such a large extent the development of forestry in all its branches.

9. Improvements in Methods of Mensuration.

In scientific directions, the mathematical disciplines were the first to be developed, the natural scienc'es received attention much later.

A considerable amount of mathematical knowledge was required for this work of forest organization. The mathematical apparatus even at the end of this period was rather slender, but its development went hand in hand with the development of these methods of regulation, and even elaborate mathematical formulæ for determining felling budgets were not absent. 
Until nearly the middle of the 18th century surrevs of exact nature were almost unknown; only when the division into equal or proportionate felling areas became the basis for determining the felling budgets, did the necessity for such surveys present itself.

Plane table and compass were the instruments which came into use in the beginning of the 18th century. But not until the latter half of that century were extensive forest survers and maps of various character made, especially in Prussia under Wedell, Kropff and Hennert.

The methods of measurement of wood developed still later. Until Oettelt's time no method of precise determination of volumes was known, everything being estimated by cords or by diameter breast-high and height, or by the number of boards which a tree would make (board feet?).

The diameter was sometimes used as a price maker, the price increasing in direct proportion to the diameter increase. Oettelt calculated the volume of coniferous trees as cones and Vierenklee, who wrote a book on mathematics for the use of foresters, calculated timbers with the top removed by the arerage diameter, to which Hennert added the volume of a cone with the difference of the two diameters as a base to make the tree volume

Most measurements of standing trees were, of course, made on the circumference, for, in the absence of calipers, only the diameter could be directly measured on the felled tree. Doebel had already measured the height by means of a rectangular triangle and the first real hypsometer with movable sights was described by Jung in 1781, and a complete instrument, which could be used for measuring both height and 
diameter at any height, similar to some more modern ones, was constructed by Reinhold.

Determination of the real wood contents in a cord of wood and of the volume of bark by measurement was taught by Oettelt, and the method of immersion in water and measuring the displaced volume, by Hennert (1782).

In $1785 \mathrm{Krohne}$ first called attention to the variation of the accretion in different age classes and the need of determining the accretion for each separately.

In 1789 Trunk taught how to determine average felling age accretion, and also the method of determining the change of diameter classes, which is now used by the United States Forestry Bureau: "On good soil a tree grows one inch in three years, on medium soil in four years, on poor soil in five years." With this knowledge the attainment of a given diameter, or the change from one diameter or age class to the next could be calculated.

Volume tables were at Trunk's command, and Paulsen in $178 \%$, Kregting in 1788, mention periodic yield tables; but generally speaking "ocular taxation" or estimating was the rule, checked by experience in actual fellings, the method of the American timber looker. Generally, of course, only the log timber was estimated as with us, and only the very roughest estimating or rather guessing was in vogue until near the end of the period.

The first attempt at closer measurement was made by Beckman (1756); who surrounded the area to be measured with twine, drove a colored wooden peg into each tree, one color for each diameter class, when, knowing 
the original number of pegs that had been taken out, the difference gave the number of trees in each diameter class, and by multiplying the average cubic contents of a measured sample tree in each class by the number in the class its volume was found.

The method, often employed at present, of ascertaining by tally the diameter classes on strips forty to fifty paces wide, the so-called strip method, was described by Zanthier in $\mathbf{1 7 6 3 .}$

These measurements were usually confined to sample areas, the use of such being already known in 1739. The contents of the sample area, if a special degree of accuracy was desired, was ascertained by felling the whole and measuring.

Oettelt, of mathematical fame, was the first to publish something about the determination of the age of trees by counting rings, although the practice probably antedates this account. He knew of the dependence of the ring width on the site and on the density of the stand.

It seems that long before this time the French had made the determination of yield in a more scientific manner, Réaumur reporting in 1721 to the French Academy comparative studies of the yield of coppice and of volnmes of wood.

Oettelt, too, laid the foundation of forest financial calculations when he ascertained the value of a forest by determining the value of an acre of mature woodthe oldest age class - and multiplying it by half the acreage of the whole forest, suggesting the well known expression for the normal stock $\left(\mathrm{I} \frac{\mathrm{r}}{2}\right)$ soon after to be developed by an obscure Austrian tax collector. 
Even the first forest finance calculations with the use of compound interest, and a comparison of the profitableness of the different methods of management, are to be recorded as made by Zanthier in 1764 , bringing the beginning of forestal statics into this period.

\section{Methods of Lumbering and Utilization.}

At the beginning of this period rough exploitation was still in vogue, only parts of trees being used, just as in the United States now. Here and there attempts were being made toward more conservative use of trees, for instance, at Brunswick in $\mathbf{1 5 4 7}$ the use of log timber for fuel was discouraged. We find also that in Saxony, as early as 1560 the brushwood was utilized for fuel. High stumps were a usual feature in spite of the threats of punishment which some of the forest ordinances announced, as in Bavaria (1531). The axe was the only instrument used until the end of the 18th century, for felling as well as cutting into lengths; not until 1775 do we find an allusion to the use of the saw, when the forest ordinance of Weimar ordered that the saw-cut should be made for three-fourths of the tree's diameter and the axe be used to finish (!) the last quarter. Not until the 18th century was the fuel-wood split and it was near the end of the period before it was set up in mixed cords (round and split) after the splitting had been introduced. The measure was, until about that time, merely in loads, the cord being of later introduction.

The value of low stumps and of the use of the saw was recognized in Austria in 1786. To show how variously and locally the need of conservative use of wood de- 
reloped, we may cite the fact that in the Harz, about 1750 , trees were dug with their roots, in order to utilize more of the body-wood and the root-wood. In $175 \%$ we find stump-pulling machines described.

In measurement of standing trees the circumference at breast-height was measured with a chain, and for the body-wood when felled the mean diameter was employed.

As regards the felling time, specific advice is found in many forest ordinances which recommend mostly winter felling, stating the proper beginning and end of the season by the phases of the moon, the rule being that all white wood, for example conifers, beech and aspen should be felled on the increase or waxing of the unoon, oak, at the waning, but coppice because it is desired to secure a new growth, at the waxing moon. Prescription was also made sometimes regarding the time by which the removal of the wood from the felling area was to be finished (May to June).

Means of transportation were poor up to the end of the period; snow, as in the United States, was in the Northern country the main reliance for moving the wood. River driving, both with, and without rafts was well organized; various systems of log-slides were dereloped to a considerable extent; in one place even an iron pipe, 900 feet in length, is reported to have been used in such capacity.

Originally the consumer cut his own wood, but in the middle of the 17 th century special wood-choppers appear to have been employed, for in 1650 mention is made in Saxony of men who were placed under oath and were organized for the exploitation of the different classes of wood. A system of jobbers came into existence 
about this time, something like the logging bosses in the United States (Holzmeister) who were responsible for the execution of the logging job. The organization of wood-choppers went so far that in $1 \% 18$ we find in the Harz mountains mention of an Accident Insurance and Mutual Charity Association among them.

The sale of wood was at first carried on in the house; later it became customary to indicate in the forest the trees to be cut or the area from which they should be cut by the purchaser and finally they were felled by the employes of the owner. For a long time, persisting into the 18th century the sale was by area, and this method developed the necessity of surveying; at the same time, however, sales by the tree and by wood measure occurred, but only in the 18th century did the present method of selling wood by measure after felling come into existence. In Prussia the buyer had to take the risk of felling, and pay, even if the tree proved to be rotten, or broke in the felling. 'The forest owner seems to have had the whip hand in determining the price one-sidedly, revising, i. e., increasing the toll in longer or shorter intervals. But in 1713 we find mention of wood-auctions, or at least similar methods of getting the best prices. Finally, special market days for making sales and for designating of wood were instituted; on these days also all offenses against the forest laws were adjudged.

The exercise of the Forsthoheit (princely supervision) originating in the ban forests and favored by the mercantilistic and absolutist ideas of the 17th and 18th centuries, gradually grew until the end of the 18th century to such an extent that the forest owners them- 
selves were not allowed to cut a tree without sanction of some forest official, and could not sell any wood without permission, even down to hoppoles, although the large landed property owners strenuously resisted this assumption of supervisory powers. Much discussion and argument regarding the origin of this right to supervision was carried on by the jurists, who upon the basis of Roman law doctrine, proved it to be of ancient date.

The degree, however, to which this supervision was developed varied considerably in the different parts of the empire, according to different economic conditions. The interference with and protection of forests appeared more necessary where advanced civilization and denser population created greater need for it. We find therefore that the restrictive policy was much more developed in the Southern and Western territories than in the Northern and Eastern ones, where such development begins two hundred years later.

\section{Forest Administration.}

The administration of the different forest properties which the princes had aggregated in the course of time was at first a part of the general administration of the princely property. The requirements in the woods being merely to look after utilization and protection, illiterate underlings (Forstknechte) were sufficient to carry out the police functions, generally under a Forstmeister, or Oberforstmeister, who from time to time would make an inspection tour. Later on when a more intensive forest management had come into existence it became customary to call in for such inspection experienced foresters from outside to give advice. 
A much more elaborate organization of service is, however, reported in the mining districts of the Harz mountains in 1547, with the Director of Mines (Berghauptman) at the head, and different grades of officials under him who were called together periodically for reports and discussions.

Until the middle of the 18th century all those employed in the forest service had also duties in connection with the chase, at least, those in the superior positions, the head official of the hunt being also the head of the forest service, and hunting had usually superior claims to forestry. The men were supposed to be masters of the two branches, i. e. to be familiar with the technique of the hunt and of forestry (Hirschgerecht and Holzgerecht). The higher positions were usually reserved to the nobility until (during the 18th century) the Cameralists came into control of the administration, and with them under the mercantilistic teachings the apparatus of officials also increased.

These men usually possessed wide, but not deep knowledge of matters bearing upon their charges. In Prussia, in 1740, the forest service was at least in part combined with the military service, Frederick the Great instituting the service of riding couriers for the carrying of dispatches and these couriers were selected from the forest service, an institution which persists up to date in the corps of Feldjaeger, while the sons of foresters were enlisted in a troop known as Fussjaeger (chasseurs). A new era dates from the middle of the 18th century when the connection with the hunt, the military organization and the nobility, was at least in part abrogated, and a more technical organization was attempted. The cause 
for this severance was the increase of wood prices, which made a more technical management desirable, and also a decrease in the passion for the hunt. Still, although the forests, in Bavaria, were declared in 1780 to 1790 to be of more importance than the hunt, the two services being distinctly separated, the head of the hunt still ranked above the head of the forest service.

In Prussia the professional men became early independent and influential, and by $17 \% 0$ an organization had been perfected which excelled in thoroughness and simplicity. The salaries of the foresters consisted originally mainly in a free house, use of land and pasture rights, their uniform, and incidental emoluments. like toll for the designation of timber, etc. Later, when a regular money management had been everywhere else introduced, the absence of a cash income and general poverty forced the foresters to steal and extort; and the bad reputation established in the last part of the 18th century, as well as the bad practice, persisted until the 19 th century. The lower grades in the service were exceedingly ignorant, and their social position, consequently, very low. Their main business was, indeed. simple, and consisted in the booking of the cut, issuing permits for the removal and the sale of wood, and looking after police functions in the woods. Yet by 1781 we find a regular planting plan submitted in the Prussian administration, and in 1787 a felling plan.

The administration of justice against offenders in the forests was until the end of the 18th century in charge of the head foresters and only then was transferred to law officers. Theft of wood, as in olden days, was considered as a lesser offense than other thefts, except when the 
wood was cut. In the beginning of the period the judge had wide latitude as to amount of the fine to be imposed, but in the 17th century more precise fines were fixed, and in the 18th century a revision of the fines brought them into proportion with the value of the stolen wood and a choice of punishments by fines, imprisonment or labor in the woods was instituted.

\section{Forestry Schools.}

The course of education for the foresters until the middle of the 18 th century was a simple one and mainly directed to learning the manipulations of the chase, training of dogs, tending of horses, setting the nets, shooting, etc. Two or three years' life with a practical hunter were followed by journeying and working for different employers, woodlore being picked up by the way from those that knew.

When in the 18th century the need for better woods knowledge became pressing, the few really good forest managers were sought out by the young men who wished to secure this knowledge. In this way a number of socalled "master-schools" came into existence, each dopending on one man. Such a school was that of $\nabla$. Zanthier in Wernigerode, later transferred to Ilsenburg, started in 1764 and ending with his death in 1778. Theoretical teaching and opportunity for practical demonstration here was such that even students from the Berlin school and men in actual employment attended the courses.

The two great masters and fathers of modern forestry, Hartig and Cotta, each instituted such master-schools, the former in 1789, and the latter in 1785 . Cotta's 
school was afterwards transferred to Tharand and became \& State institution.

The first interest of the State in forestry education found expression in a course of lectures in botany, later in forest economy, given to the forest officials by Gleditsch, professor of botany at the University of Berlin (1770), to which was added a practicum at Tegel under Burgsdorf, who finally became the head of this mixed State school, and continued in this position until at his death, in 1802, the school was discontinued.

In imitation of this move by Prussia, a military planting school was instituted by Würtemberg at Solitude in 1770. The most noteworthy feature of this school, which under various changes lasted less than 25 years, was the course of lectures by Stahl, mentioned before.

Besides this higher school, a lower grade school was started in 1783, but its career was even briefer, not more than ten years.

Bavaria organized a forest school at Munich in 1790 with a four years' course, and at least three years' study at this school was required of those seeking employment in the State service, but without having ever flourished, this school, too, collapsed by 1803 .

\section{Forestry Literature.}

The oldest forestry literature of this period is contained in the many forest ordinances, which allow us to judge from their prescriptions as to the conditions of the practice in the woods and as to the gradual accumulation of empiric knowledge. Of a forestry science one could hardly speak until an attempt had been made to organize the knowledge thus empirically acquired into 
a systematic presentation, and this was not done until the middle or last half of the 18th century.

The first attempts at a literary presentation of the empiric knowledge are found in the encyclopædic volumes of the so-called "Hausväter" (household fathersdomestic economists), who treated in a most. diffuse manner of agriculture in all its aspects, including silviculture.

A number of these tomes appeared during the 1 th century; the best and most influential being published at the very beginning of that century (1595-1609), written by a preacher from Silesia, Johann Colerus, and entitled Oeconomia ruralis et domestica, worin das ampt aller braven Hausväter und Hausmütter begriffen.

Colerus relied upon home experience and not, as the earlier work, Praedium rusticum (translated from the French, in 1592), had done, upon the scholastic expositions of the Italian, Petrus de Crescentiis, who reproduced much of the Roman lore, entirely inapplicable to German conditions. He was rewarded by the popularity of his work which went through thirteen editions and became very widely known.

Somewhat earlier, a jurist, Nö̈ Meurer, wrote a book on forest law (second edition, 15\%6) and hunting which on this field remained long an authority, and gives insight into the condition of forest use at the time.

But the first independent work on forestry, divorced from the hunt and farming, did not appear until 1713, Sylvicultura ceconomica, written by the Saxon director of mines, Hans Carl v. Carlowitz.

This book, while containing quaint and amusing ideas, gives many correct rules for silvicultural methods, 
especially as regards planting and sowing, but the subject of forest management or organization is entirely neglected.

At about the same time (1710) a forest official, $v$. Göchhausen, published Notabilia venatoris, which, however, contained little more than a description of the species of trees and methods of their utilization.

About the middle of the 18th century great activity began in the literary field. This was carried on by two distinct classes of writers, namely, the empiricists and the cameralists. The former-the holzgerechte Jägerwere the "practical" men of the woods who proved in many directions most impractical and exhibited in their writings, outside of the record of their limited experience, the crassest ignorance. The cameralists were educated in law and political economy, who, while lacking practical contact with the woodswork, tried to sift and systematize the empiricists, and to secure for it a tangible basis.

Some five or six of the empiricists deserve notice as writers; the first and most noted of them was Doebel (Heinrich Wilhelm) whose book, "Jägerpraktica" (hunters' practice), published in 1746, remained an authority until modern times for the part referring to the chase. The author was pre-eminently a hunter, who worked in various capacities in Saxony, a self-taught man with very little knowledge of natural history.

Being familiar mainly with broadleaf forest he condemned planting and thinning, but described quite well for his time the methods of survey, subdivision, estimating and measuring and the methods of selection forest. and coppice with standards. 
His ignorance is characterized by his reference to the "sulphurous and nitric elements of the soil" as cause of spontaneous forest fires.

Opinionated and one-sided, like many so-called practical men, he came into polemic controversies with other practitioners, not less opinionated, among them $J$. G. Beckmann, who worked in another part of Saxony, where, having to deal with coniferous woods, he had gathered different experiences from those of Doebel. Although he was himself poorly educated, especially in natural sciences, he complained of the ignorance of the foresters, and in his book (Anweisung zu einer pfleglichen Forstwirthschaft, 1759), used for the first time the word Forstwissenschaft (forest science), and insisted upon the necessity of studying nature.

He may be credited with having really advanced forest organization by devising the first good rolume division method and silviculture by adrocating the method of clearing with sowing.

The first practical forester with a university education was J.J. Büchting, who worked in the Harz mountains. His main interest lay in the direction of survey, division and orderly utilization. He did not, however, make any striking advance, except that he gave equal standing to both planting and sowing.

The two most eminent practitioners of the period, however, active during the middle of the century, were Johann Georg von Langen and his pupil, Hans Dietrich von Zanthier, both of noble family, and better educated than most of their contemporaries and both engaged in the organization and management of Harz mountain forests, namely, those of the Duke of Brunswick and of the Count of Stolberg-Wernigerode. 
The former, without occupying himself with literary work, laid down in his expert reports and in his working plans many instructions, which form the basis for orderly management and silviculture far ahead of the times. Zanthier, writing considerably (especially Kurzer systematischer Grundriss der praktischen Forstwissenschaft, 1764), is also notable as the founder of the first forestry school (at Wernigerode), 1763.

Another of this class of better educated practitioners, and co-worker with the former two, was von Lassberg, who in 1764-177\% organized the Saxon forests.

An interesting incident in the life of the last three men is their journey to Denmark and Norway, whither they were called to organize the management of the forests connected with the mines.

Another prominent forest manager of the last half of the century, whose literary work is to be found only in various excellent official instructions, among which is one for the teaching of foresters, was the head of the Hessian forestry service, a nobleman, v. Berlepsch.

Of the cameralists who helped to make forestry literature, six or seven deserve mention. These, men of education and polyhistors, were either at the head of affairs or else professors at universities, where they included forestry as one of the branches of political economy.

The credit of the first really systematic presentation of forestry principles and rules, as developed at the time, belongs to Wilhelm Gottfried von Moser, a pupil of von Langen, who served in various principalities, and finally with the Prince of Taxis. In his Principles of Forest Economy, published in $175 \%$, which for the first 
time brought out the economic importance of the subject, he discusses in two volumes divided into nine chapters the different branches of forestry.

A mining engineer, J.A. Cramer, came next with a very notable book, "Anleitung zum Forstwesen" (1766). which, although not as comprehensive as Moser's, treats the subject of silviculture very well.

Equal in arrogance and opinionated self-satisfaction to any of the empiricists with whom he frequently crossed swords, was the Brunswick councillor, von Brocke, who, as an amateur, practising forestry on his own estate, developed the characteristic trait of the empiricists, namely, a profound belief in his own infallibility. He produced, besides many polemic writings, in which he charged the whole class of foresters with ignorance, laziness and dishonesty, a magnum opus in four volumes, entitled "True bases of the physical and experimental general science of forestry," which is an olla podrida of small value.

Less original, but more fair and well informed, a typical representative of the cameralists, was J.F. Stahl, finally head of the forest administration of Würtemberg, and at the same time lecturer on mathematics, natural history and forestry at the forest school of Solitude (Stuttgart). Although an amateur in the field of forestry, he was a good teacher and left many valuable and wise prescriptions evolved during his administration.

He compiled in four volumes a dictionary of forest; fish and game practice (Onomatologia forestalis-piscatoria-venatoria, 1772-1781) and founded the first forestry journal.

Since 1770 forestry courses had been given for the 
cameralists at most of the German universities and many of the professors prepared textbooks for the purpose. At least three of these professors deserve mention, Beckman, Jung and Trunk.

The first, J. Becleman, professor of political economy at Göttingen, one of the most noted cameralists, was author of a work in forty-five volumes on the Principles of German Agriculture (1769), in which he devotes sixty-one pages to forestry, giving a complete system of forestry with extracts from all known forestry writings.

$J$. H. Jung, who gave a special course on forestry at the Kameralschule of Lautern, published a textbook in 1781 in which forest botany was well treated.

J.J. Trunk, who was Oberforstmeister in Austria, as well as professor at Freiburg, was the most prominent of the three, and wrote a comprehensive work full of practical sense (Neues vollständiges Forstlehrbuch oder systenuatische Grundsätze des Forstrechtes der Forstpolizei und Forstökonomie, nebst Anhang von auständischen Holzarten, von Torf und Steinkohlen, 1789).

While at first the ephemeral writings, especially the polemic ones of the empiricists, found room in literary and cameralistic magazines, the need of a professional journal first found expression in 1763, in Stahl's Allgemeines ökonomisches Forstmagazin, which ran into twelve volumes, and contains many articles important to the history of forestry, and is especially rich in its references to foreign literature.

Two continuations of the magazine under different editorships were of less value. But von Moser's Forstarchiv, running from 1788 to 1807 with its thirty vol- 
umes, is an authority and a historical source of the first rank.

A very characteristic literature of the last half of the 18th century consisted in forest calendars in which advice as to monthly and seasonal procedures in the forest were given, Beckman and Zanthier being among the authors.

\section{Development in the Nineteenth Century.}

The last hundred years or so has seen in Germany the development of fully established forest policies and the complete organization of stable forest administrations, based upon thorough and careful recognition of the principles of forest management and intensive application of silvicultural methods.

\section{Changes in Property Conditions.}

The change in forest treatment from the conditions prevailing during the previous period was largely due to the change in property relations, and especially to the establishment of state forests. This change was largely the result of the revolutionary movements at the beginning of the new century which brought about changes in state organizations. With the exception of Prussia, where the princely forest property had been declared state domain in 1713 , elsewhere the public domain had been considered the property of the princes as such, outside of their personal private property (Cha- 
tallguiter). The income from this domanium was in part liable to be applied to the expenses of the court, of the administration, of the realm, as far as possible alleviating the burdens of taxation. This property arose from a variety of relations which have been discussed at length in the foregoing chapters. It was derived mainly from feudal properties, fiefs of vassalage and fiefs of official position, secularized church property and other forfeited property, division of mark forests, to which were added the allodial possessions of the family. Gradually, by agreement with the landed estates, it was understood that this property could not be disposed of or dissipated, and was inherited by the eldest son together with the princely dignity, being an attribute of his position in the state. In the reorganization period of 1806 to 1815 , many of the small princes lost their seignorage. (Landeshoheit ipso jure) and with the loss of the princely dignity, the obligation of carrying the expense of court and administration naturally falling away, these properties became in most cases purely individual property of the former princes.

Not, however, until the revolutionary movements of 1848 and even later was this divorce of the state idea from that of the person of the prince everywhere accomplished, nor was it carried through without many bickerings and quarrels between the princes and the representatives of the people, who claimed this domanium for the state. In the larger states all this domanial property was finally declared state lands, while in the smaller principalities a partition of the land between the princes and the state took place or else a relation was established by which a part of the revenue resulting from the state lands was secured to the princes. 
An increase of the State's property came also during the first decade of the century through the abolishment of cloisters and secularization of church property generally, the lands of both Protestant and Catholic institutions being taken by the State.

Curiously enough, at the same time that the idea of state forest was being realized, the changes in economic thought which brought the principle of individualism into vogue gave rise to a movement to sell the state properties. This movement was inspired by French doctrines, whose influence was at the time very strong, by the teachings of Adam Smith to the effect that the state is not fit to conduct business, and by the hope that in private ownership an improvement in forest conditions would be more readily realized. These ideas alone would, probably, not have led to the adoption of a policy of sale if it had not been for the need for cash which, owing to the French wars, was everywhere felt during the first years of the decade. The sale of this property seemed to provide a ready means for the State to secure funds.

In Prussia, after the collapse of 1806 , this measure was widely discussed, and from the years 1810 to 1813 led to the instructions for the sale of state forest property, excluding only large complexes of forest, those on the sea coast, sand dunes and river fronts, where the protection of the forest cover was needed, as well as those which it was desirable to maintain for the use of important industrial establishments. Only the accession of Hartig as chief of the forest administration under the treasury department (1811) prevented the execution of this dismemberment. It was due to him that the differ- 
ence in position between farm and forest property began to be recognized. Although after 1820 sales of forest property took place, they were never a fiscal measure, but were made either for the purpose of rounding off existing state forest property or paying off servitudes, or else in order to turn over agricultural soil to farm use. At present everywhere in Germany state properties are on the increase.

The property conditions of the communal forests naturally changed also with the political changes of the 19th century, when existing communities were made part of the large political machine and changed from economic and social to modern political municipalities. The ownership conditions, however, were not simplified, but as before, remained extremely varied.

Of the Mark forest but a very small portion remains to-day. The majority of it had been finally divided among the Märker in the first decade of the century, and the few remaining parts became independent of the political organization and now exist merely in the form of appurtenances to certain farm property known as Genossenwald (association forests). In adition to the variety of communal ownerships existing in the preceding period, some new communal properties originated from the granting of land in the settlement and dissolution of servitudes, whereby an undivided property (Interessentenwald) in which sometimes even the state retains an interest, came into existence.

The municipal property of the cities had become either the property of the entire community or of that part which constituted the real citizenship, or at least of a certain class of citizens of the municipality. 
The incumbrances which had grown up with regard to forest property under the name of servitudes and which so much retarded the development of better forest management continued into this period, and although through the influences of the French revolution a desire had been stimulated to get rid of all curtailments of property, some have persisted to this day. Indeed, for a time an increase of these servitudes took place, due to the carelessness of forest officials in keeping unjustified use of the forest in check, when ancient usage of these rights of user was claimed and new servitudes were established.

Indeed, in Bavaria, it became at last necessary (1852) to positively forbid the further establishment of new servitudes or rights of user. Laws having in view the dissolution or buying out of these rights were issued in Bavaria in 1805 and in Prussia in 1821, giving the right to forest owners to call for a division of interests; but as at first the only way of settlement was by exchange for definite parcels of forest property, the progress in the abolishment of these rights was slow, until money exchange was permitted (as in Saxony, 1832). At the present time the state forest administrations have mostly got rid of these servitudes, or at least have progressed so far in their regulation that they are now rarely impediments to forest management. These peaceable adjustments of the rights of user constitute the last act of freeing property socially and economically.

\section{Forest Conditions.}

In spite of the sporadic efforts which had been made to bring about the recuperation of forest areas during 
the 18th century, the conditions of the forest at the beginning of the new century were most pitiable; the division of the Mark by which the peasants became individual owners, profited little and led to devastation rather than to improving the condition of the property. In addition, export trade in wood had become brisk and the financial depression, a result of the French wars, led to increased exploitations, which, with the improvement in means of transportation, progressed to the more distant forest areas and enlarged the waste area. Especially in the more densely populated parts of the country the deforested area widened, and large wastes with poor young growth increased in all directions in the same manner as now in the United States. The alarmists had good cause for renewing their cries and about the year 1800 a considerable literature on the subject of the threatening timber famine grew up, and the desire for rapidly growing species became once more prevalent.

It is interesting to note that at that time the Catalpa played a role, at least on paper, as it does in our own day, being recommended in 1801 as the only means of counteracting the timber famine. The betulomania spread widely over the country. In North Germany especially great efforts were made to replant the denuded areas and to change the coppice areas, fit only for firewood, to coniferous species, pine, etc., by which eventually a great change in the forest type from the original mixed forest to the pure forest was effected.

\section{Personnel.}

The great change to improved conditions, which took place in the first half of the century, was pre-eminently 
due to the knowledge and intelligence of a group of men, six in number, competent foresters, who combined the high grade education of the Cameralists and the practitioners' knowledge: Hartig, Cotta, Hundeshagen, Koenig, Pfeil and Heyer. These men built on the shoulders of their precursors of the century in which they were born, and being placed in authoritative pasitions, found opportunities of putting their teachings into practice.

The first two mentioned were older than the rest, and are usually described as "fathers of modern forestry." Born about a year apart, both educated at universities, they excelled both in scientific and practical directions. - Georg Ludwig Hartig (1764-1837), studied at the University of Giessen and, after having served in various functions in various parts of Southern Germany, became, in 1811, head of the Prussian forest administration. He was equally eminent as a practical man and organizer, as a writer and as a teacher. In literary direction his work lay not so much in developing new ideas as in formulating clearly the known ones, as evidenced in his celebrated "General Rules" in silviculture.

Not less than thirty separate publications attest his assiduity. Among them stands pre-eminent "Anweisung zur Holzzucht für Foerster" (1791; 8th edition, 1818). As a teacher he began his work by establishing a masterschool (1789-1791) at Hungen, transferred to Stuttgart in 1807; and afterwards, as head of the Prussian forest administration, he lectured at the University of Berlin, continuing his lectures even after the forestry school at Eberswalde was established, until his death. $\checkmark$ He may be considered as having established on a firm 
basis the forest administration of Prussia, and many of the things he instituted still prevail. In organizing the service he introduced fixed salaries and relieved the foresters from financial responsibilities, transferring all handling of money to a separate set of officials, whereby the attempt at fraudulent practice or graft was removed. He issued instructions for the different grades of foresters and every part of this work was all his own. In regulating the forest area of the state he developed the volume allotment method, which, however, proved too cumbersome to be readily applied to large areas. Toward the end of his life his work was not entirely successful and he lost prestige in his later years.

Heinrich von Cotta (1763-1844) studied at the University of Jena and afterwards practiced in Thuringia, where he established a master school at Zillbach (1795). In 1811 he was called to Tharand, Saxony, as director of forest surveys, whither he also transferred his school, which in 1816 was made a state institution and is still flourishing. In that year he was made the director of the Bureau of Forest Management. Like Hartig, he was eminent in the three directions of practical, literary, and professional work, but he excelled Hartig in originality, developing new principles and thought. Being a good plant-physiologist and observer of nature, he dereloped new ideas in silviculture, especially with reference to methods of thinnings, and his "Anweisung zum Waldbau,' written in the simplest, clearest and most forceful manner, forms a classic worthy of study to this day. In the field of forest management he became the inventor of the area allotment method and the originator of the highly developed Saron iorest management. As 
a teacher he excelled in clearness, exposition, wealth of ideas and geniality.

Of an entirely different stamp was the third of the great masters, Johann Christian Hundeshagen (17831834), who having studied in Heidelberg, became after some years of practice, professor of forestry at Tuebingen, in 181\%, and at Giessen, 1825. He was a representative of the theoretical or philosophical side of forestry, being highly cultivated and imbued with the spirit of science. His bent was to systematize the knowledge in existence and extend it by means of exact experiments. In forest organization, he invented the well known formula method or "rational method" of regulating felling budgets and became also one of the founders of Forest Statics (1826) which he called "the doctrine of measuring forestal forces," being thus the forerunner of modern scientific forestry.

The fourth of the group, Gottlob König (1צ6-1849) was a practitioner without a university education, who had enjoyed the teaching and influence of Cotta whom he succeeded in Eisenach as the head of the ducal forest administration. He also founded here a private forest school, which in 1830 became a state institution and is still in existence. König became noted by his contributions to the scientific, especially the mathematical side of forestry, developing forest mensuration and statics. In this latter branch he was the forerunner of Pressler and the modern school of finance. In his "Anleitung zur Holztaxation" (1813) he gives a complete account of forest mensuration and in the part devoted to forest valuation he develops the first soil rent formula and the methods of determining the cost 
value of stands. His "Forest Mathematics" (1835) in which he introduces factors of form and many other new ideas was an original contribution to science.

Very different in character from these four leaders was the aggressive, sharp-witted Friedrich Wilhelm Leopold Pfeil (1783-1859), who, without a university education, and in spite of his poor knowledge of mathematics and natural history, advanced himself by native wit and genius. After a brief period of employment in private service, in the province of Silesia, he accepted the position of professor of forestry at the Berlin University in 1821 in connection with Hartig, with whom, however, he was at sword's point. It was at his instigation, with the assistance of von Humboldt, that the school was transferred, in 1830, to Eberswalde, Pfeil becoming its director.

While Hartig was a generalizer, Pfeil was an individualizer, free from dogma and most suggestive; a free lance and a fighter. Critical in the extreme and prolific in his literary work, he domineered the forestry literature of the day by means of his Kritische Blaetter, a journal of much import and merit.

Kar1?

The youngest of the group, Gustav Heyer (17991856), a thoroughly educated man, combined the professorial position in the University of Giessen (1835) with practical management of a forest district, but in 1843 abandoned the latter in order to devote himself entirely to literary work. He was one of the clearest and most sytematic expounders, and both his Waldbau (silviculture, 1854) and his Waldertragsregelung (forest organization, 1841) are classics. He devised one of the most rational methods of forest organization, and, im- 
bued with the necessity of basing forest management on exact scientific inquiry, instead of on empiricism alone, he formulated instructions for forest static investigations, a subject which his son, Gustav Heyer, elaborated into a science.

4. Progress in Silviculture.

a. Natural regeneration continued to be the favorite method well into this period, and for a long time selection forest and coppice were all that was known in practice until Hartig and Cotta forced recognition of the shelterwood system.

The only way in which a transition from the generally practiced, unregulated selection forest to an intensive management was possible, with the ignorant personnel of underforesters, was to formulate into an easily intelligible prescription the necessary rules, allowing the least play to individual judgment. This was done by Hartig when he formulated his eight "General Rules" (1808) which coincided also closely with the teachings of Cotta. Since these rules represent in brief and most definitely the status of silvicultural knowledge on natural regeneration at the time, it may be desirable to translate them verbatim.

(1) "Every forest tree which is expected to propagate itself by natural regeneration must be old enough to bear good seed.

(2) "Every district or stand which is to be replaced by a thoroughly perfect stand by means of natural regeneration, must be brought into such position (density) that the soil may everywhere receive sufficient seeding.

(3) "Each compartment must be kept in such condi- 
tion (density) that it cannot, before the seeding takes place, grow up to grass and weeds.

(4) "With species whose seed loses its power of germination through frost, as is the case with the oak and beech, the compartments must be given such a position (density) that the foliage which after the fall of seed covers and protects the same cannot be carried away by wind.

(5) "All stands must be given such density that the germinating plants in the same, as long as they are still tender, find sufficient protection from their mother trees against heat of the sun and against cold.

(6) "So soon as the young stand resulting from natural regeneration does not any longer require this motherly protection, it must gradually, through the careful removal of the mother trees, be accustomed to the weather, and finally must be entirely brought into the open position.

(7) "All the young growths, whether secured by natural or artificial seeding, must be freed from the accompanying less useful species and from weeds, if these in spite of all precaution threaten the better kinds.

(8) "From every young forest until it is full grown, the suppressed wood must be removed from time to time, so that the trees which are ahead or dominate may grow the better; the upper perfect crown cover, however, must not be interrupted until it is the intention to grow a new forest again in the place of the old one."

Since these rules are applicable only in beech forests, much mischief and misconception resulted from their generalization; pure even-aged high forests became the ideal, and the mixed forest, which was originally the 
most widespread condition, vanished to a large extent. This was especially unfortunate in Northern and Northeastern pine forests.

A reaction from Hartig's generalization began about 1830 under the lead of Pfeil. He had at first agreed with Hartig, and then with equal narrowness advocated for many years a clear cutting system with artificial reforestation. Finally he was not afraid to acknowledge that his early generalizations in this respect were a mistake, and that different conditions required different treatment.

In the development of the shelterwood system there was at first under the lead of Hartig, a tendency to open up rather sharply, taking out about three-fourths of the existing stand, but gradually he became convinced that this was too much, and finally reduced the first removal to only about one-third of the stand. This was the origin of his nickname of Dunkelman. In spite of the fact that it was claimed that Cotta took the opposite view (for which he was called Lichtman), he, too, grew to favor a dark position, and, as he progressed, leaned more and more towards more careful opening up. Hartig originally recognized only three different fellings: the cutting for seed; the cutting for light; and the removal cutting. By and by a second cut was made during the seed year, and the number of fellings to secure gradual removal were increased so that by 1801 this system seems to have been pretty nearly perfected to its modern conditions. The best exposition of this Femelschlagbetrieb (shelterwood system), as then developed, is to be found in Karl Heyer's Handbook, 1854.

The method was unfortunately extended to the North- 
ern pineries with a seventy year period of rotation, by Burgsdorf (1787). Within ten years, however, he recognized its inappropriateness, and modified it by instructions to leave only six to twelve seed trees per acre. His successor, Kropff, reduced the number to four or five, which were to be removed within two or three years. In spite of the development of this more rational method, the practitioners under Hartig's approval, held mainly to a dark position, much like a selection forest, which produced a poor growth of oppressed seedlings, retarding for a long time the development of the pineries.

In spruce or fir either a pure selection forest or a strip system was employed. Attempts at a shelterwood system were made, but experience with the wind danger soon taught the lesson that this was not a proper method with shallow-rooted species. Even Hartig preferred clearing and planting with the spruce, and this is still the most favored method with that tree. For the deep-rooted and shade enduring fir the shelterwood method, with a long regeneration period, was thoroughly established in the Black Forest and in Würtemberg by 1818.

\section{b. Artificial Reforestation.}

Natural regeneration being the main method of reproduction until the beginning of the 19th century, artificial means were usually applied only to repair failplaces, or to plant up wastes, as is evident from the forest ordinances of Prussia and Bavaria (1812 and 1814). In this artificial reforestation, with the exception of the planting of oak in nastures, sowing was almost entirely 
resorted to because it was cheaper and easier, but as the sowings were mostly done on unprepared soil and with very large amounts of seed (30 to 60 pounds per acre, now only 7 to 10 pounds), the results were not satisfactory, either because the seed did not find favorable conditions for germinating, or when germinated the stand was too dense.

Planting, if done at all, was done only with wildlings, dug from the woods, and usually, following the practice of the planting of oak in pastures, with saplings: the plant material was too large for good success. Nurseries, except for oak, were not known, even to Cotta in 181\%; and Heyer, having to plant up several thousand acres, still relied on wildlings, two to three years old, which he took up with a ball of earth by means of his "hollow borer," a circular spade re-invented by him and much praised by others. Hartig in 1833 still advised the use of four to five year old pine wildlings, rootpruned, but having met with poor success, for which he was much discredited, came to the conclusion that unpruned two year old plants were preferable.

The credit of having radically changed these practices belongs to Pfeil, who, entirely reversing his position, advocated for pine forest a system of clearing followed by sowing, or by planting of wildlings with a ball of earth. Then, suggesting that possibly planting without this precaution could be attempted and pointing out the necessity of securing a satisfactory root system, he recommended, about 1830 , the use of one year old seedlings, grown in carefully prepared seed beds. While for securing these he relied upon the simple preparation of the soil by spading, Biermans added the use of a fer- 
tilizer in the shape of the ashes of burned sod. The method of growing pine seedlings and planting them at one to three years old was further developed by Butlar (1845), who introduced the practice of dense sowing in the seed beds. He also invented an ingenious planting iron or dibble, a half cone of iron, which was thrown by the planter with great precision first to make a hole and then to close it. This was improved by the addition of a long handle into the superior, well-known and much used Wartenberg planting dibble. At the same time (1840), Manteuffel devised the method known by his name of planting in mounds, which is especially applicable on wet soils.

It was not until 1840 that transplanting of yearling pines with naked roots became general. The widespread application of this latter system resulted in abandoning to a large extent mixed growths, and led to pure pine forests, introducing thereby most intensively all the dangers incident to a clearing system which are avoided by the mixed forest: insects, frost and drought.

A practice of planting spruce in bunches, originally twelve to twenty plants in a bunch, had been in existence since 1780. This practice increased until 1850, and is still in use in the Harz mountains and in eastern Prussia, although the bunches have been reduced so as to contain only from three to fire plants, the object of the bunching being to make sure that one or the other of the plants should live. Much discussion as to the merits of this method took place between the old masters, Cotta faroring the small bunches upon the basis of a successful plantation of his own, Hartig and Pfeil opposing it but finally weakening. Since 1850 , however, the practice of setting out single plants has become more general. 
A reaction from the indiscriminate application of the shelterwood method to the hardwoods and of the clearing method to the pine set in during the last quarter of the 19th century under the lead of Burkhardt and Gayer. These advocated return to mixed forest and to natural regeneration with long periods, approaching a selection forest. Yet even to this day, the principles of silvicultural treatment under the many different conditions remain unsettled. On the whole, however, the financial question having been assiduously brought forward, the clearing system has made much progress and the selection system has nearly vanished, being replaced by the group method and the shelterwood system.

A number of special forms of silvicultural management applicable under special conditions have been locally developed, without, however, gaining much ground and being mainly of historical value. Among these may be mentioned Seebach's Modified Beech Forest, which consists in first securing a regeneration, merely to form a soil cover, and in leaving enough of the old trees on the ground to close up in thirty or forty years. By this treatment the large accretion due to open position is secured without endangering the soil. Similarly the Composition or Two-aged High forest, was applied to the management of oak forest in mixture with beech. In a few localities also, on limited areas, a combination of forest and farming (Waldfeldbau) has been continued and elaborated, besides the more general use of coppice and coppice with standards.

According to the statistics for 1900 the following distribution of the acreage under different silvicultural methods prevailed throughout the empire: 
Deciduous Coniferous Per cent. Per cent.

Total Forest ........... 32.5 67.5

High Forest ............ $18.4 \quad 60.1$

Selection Forest ......... $2.3 \quad 7.4$

Coppice .............. 6.8

Coppice with standards ..... 5 .

Coniferous forest, of which $68 \%$ is pine and $30 \%$ spruce, prevails in Eastern and Middle Germany, deciduous forest, of which $20 \%$ is oak, the balance principally beech, in the West and South.

Coppice and coppice with standards are mostly in private hands as well as the coniferous selection forest, the State forests being almost entirely high forest, i. e. seed forest, other than under selection method.

c. Methods of Improving the Crop. The credit of having first systematically formulated the practice of thinnings under the name of Durchforstung (for the first thinning), Durchplenterung (for the later thinnings), belongs to Hartig, although the practice of such thinnings had been known and applied here and there before his time. He confined himself mainly to the removal of the undesirable species, dead and dying, suppressed and damaged trees, being especially emphatic in his advice not to interrupt the crown cover. Excepting the early weeding or improvement cuttings these thinnings were not to begin until the fiftieth to seventieth year in the broad-leaved forest, but in conifers in the twentieth to thirtieth year.

The first attempt to explain on a biological basis the process and effect of thinning was made by Späth in a special contribution (1802). Cotta, in his Silviculture, 
although at first agreeing with Hartig, later in his second edition (181\%) changes his mind and improves both upon the biological explanation of Späth and the practice of Hartig, pointing out that the latter came too late with his assistance, that the struggle between the individuals should be anticipated, and the thinning repeated as soon as the branches begin to die, but he also recognizes the practical difficulty of the application of this cultural measure on account of the expense. Curiously enough he recommends severer thinnings for fuel-wood production than for timber forests.

Pfeil accentuates the necessity of treating different sites and species differently in the practice of thinnings. Hundeshagen accentuates the financial result and the fact that the culmination of the average yield is secured earlier by frequent thinnings. Heyer formulates the " golden rule:" "Early, often, moderate," but insists that first thinning should not be made until the cost of the operation can be covered by the sale of the material. Propositions to base the philosophy and the results of thinning on experimental grounds rather than on mere opinion were made as early as 1825 to 1828 , and again from 1839 to 1846, at various meetings of forestry associations, until in 1860 Brunswick and Saxony inaugurated the first more extensive experiments in thinnings. The two representatives of forest finance, Koenig and Pressler, pointed out in 1842 to 1859 , the great significance of thinnings in a finance management as one of the most important silvicultural operations for A securing the highest yield.

In spite of the advanced development of the theory of thinning, the practice has largely lagged behind, be- 
cause of the impracticability of introducing intensive management. Only lately, owing to improvement in prices and the possibility of marketing the inferior material profitably enough to justify the expenditure, has it become possible to secure more generally the advantages of the cultural effect. Within the last twentyfive years, great activity has been developed among the experiment stations in securing a true basis for the practice of thinning.

New ideas were introduced through French influence and by others independently in the latter part of the eighties, when the distinction between the final harvest crop (Fr. élite, le haut) and the nurse crop (le bas) was introduced. *)

The physiological basis for the practice of thinning upon experimental grounds, was advanced by the botanists Goeppert and R. Hartig, and among foresters, the names of Kraft, Lorey, Haug, Borggreve, Wagener and others are intimately connected with the very active discussion of the subject now going on in the magazines. Thinnings have become such an important part of the income of forest administrations (25 to $40 \%$ of the total yield) that the prominence given to the subject is well justified, and a more modern conception of the advantages of thinnings and especially of severer thinnings is gaining ground.

The proposition, now much ventilated, of severe thinnings near the end of the rotation, in order to secure an accelerated increment (Lichtungshiebe) is, however,

* The conception of such subdivision and the English nomenclature was independently first employed by the writer in his Report for 1887, as Chief of Forestry Division, when discussing planting plans for the prairies. 
much older; Hossfeld, in 1824, and Jäger in 1850, advocating them for financial reasons, while Koenig and Pressler anticipated the development of an individual tree management by pruning, and differentiation of final harvest and nurse crop, a method which is working itself out at the present time.

\section{Methods of Forest Organization.}

$\checkmark$ As stated before, to Hartig and Cotta belongs the credit of having applied systematically on a large scale methods of forest organization for sustained yield; Hartig having been active in Prussia since 1811, and Cotta beginning to organize the Saxon forests in the same year.

^ The method employed by Hartig, the so-called volume allotment, had been already formulated and its foundation laid by Kregting and others (although Hartig seems to have claimed the invention). But it was reserved to Hartig to build up this method in its detail, and to formulate clearly and precisely its application as well as to improve the practice of forest survey, calculation of increment and the making of yield tables. His method involved a survey, a subdivision, a construction of yield tables and the formulation of working plans, in which the principle according to which the forest was to be managed during the whole rotation was laid down for each district. The rotation was determined, divided into periods, finally of twenty years, and the periodic volume yield represented by all stands was distributed through all the periods of the rotation so as to make the periodic felling budgets approximately equal; or, since the tendency to increased wood consumption was recognized, an increase of the felling budget toward 
the end of the rotation was considered desirable.

Cotta based his system of forest organization upon a method described by a Bavarian, Schilcher (1796); it relied primarily upon area rather than volume division. This method was later on (1817), called by him Flaechenfachwerk (area allotment). It divides the rotation into periods and allots areas for each periodic felling budget. But before this time, in 1804, Cotta had himself formulated a method of his own, which combined the area and volume method, the volume being the main basis and the area being merely used as a check. While Hartig dogmatically and persistently carried out his difficult scheme, Cotta was open-minded enough to improve his method of regulation, and by 1820 , in his Anweisung zur Forsteinrichtung und Abschaetzung, hec comes to his final position of basing the sustained yield entirely on the area allotment, using the estimate of volume simply to secure an approximately uniform felling budget. He laid particular stress on orderly procedure in the subdivision and progress of the fellings. He did not prepare an elaborate working plan binding for the entire rotation, but merely prescribed the principles of the general management, and in 1816 he made felling and planting plans only for the next decade.

A similar method making a closer combination of rolume and area allotment, now known as the combined allotment, in which the area forms the main basis for distributing the felling budgets, was prescribed by Klipstein in 1833. This confines the working plan to the first period of the rotation and for this period alone makes a rather careful statement of the expected volume budget; a new budget is then to be determined at 
the beginning of the next period. This idea of confining the budget determination to a comparatively short period is now generally accepted, the future receiving only summary consideration.

These methods of organization were the ones generally applied in practice, and are still with some modifications in practical use. About 1820, however, new theories were advanced which led to the formulation of methods based upon the idea of the normal forest. The conception of a normal forest, with a normal stock, distributed in normal age classes, so as to insure a sustained yield management, was evolved in 1788 by an obscure anonymous official in the Tax-collector's office of Austria. This fertile idea, which is still the basis of forest organization in Austria and explains better than any other method the principles involved in forest organization, did not find entrance into forestry literature in all its detail until 1811 when André compared this so-called Cameraltaxe with Hartig's method of regulation. We find, however, that simultaneously with the Austrian invention of this method Paulsen (1787) proposed to determine the felling budget as a relation between normal stock and normal yield, and in his yield tables (the first of the kind, 1795), he gives the proportion of increment to normal stock in percentic relation, so that the felling budget may be either expressed as a fraction of the stock or as per cent; in beech forests, for instance, he determines the felling budget as $3.3 \%$ on best sites, $2.5 \%$ on medium and $1.8 \%$ on poor sites.

Probably stimulated by André's description, Huber (1812) developed a method and formula which may be considered the foundation of the later development by 
Carl Heyer (Felling budget $=\mathrm{I}_{\mathrm{a}} \pm \frac{\mathrm{Sa}-\mathrm{Sn}}{\mathrm{r}}$ ). Based upon the normal forest idea, a number of methods were elaborated which, because of their employing a mathematical formula for the determination of the felling budget, are known as the formula methods; they are, indeed modified rational volume divisions. Hundeshagen has the merit of having clearly explained the basis of these methods and himself developed a formula, of the correctness of which he was so convinced as to designate his method as "the rational" one. Two other formulæ were brought into the world by Koenig (1838-1851), but the credit of the most complete elaboration both of the principles of the normal forest idea and of its practical application belongs to Carl Heyer. The principles of his method are briefly: First determine upon the period of regulation, during which the abnormal forest is to be brought nearly to normal conditions; the length of this period to be determined with due regard to the financial requirements or ability of the owner and to the conditions of the forest. The actual stock on hand is then determined and the increment which will take place during this period added. Deducting what has been calculated as the proper normal stock requisite for a sustained yield management, the balance is available for felling budgets which may be utilized in annual or periodic instalments during the period of regulation. A working plan is provided which takes care of securing an orderly progress of fellings and proper location of age classes, to be revised every ten years.

Although this is undoubtedly the most rational method yet devised, it has remained largely unused, and $\wedge$ 
is found in application only in Austria and Baden.

An entirely new principle in the theory of forest organization was introduced, when the aim of forest management was formulated to be the highest soil rent. According to this requirement the proper harvest time of any stand, or even of any tree, was to be determined by the so-called index per cent., that is, a calculation which determines whether a stand or a tree is still producing at a proper predetermined rate, or is declining. The advocates of this principle were especially Pressler (professor of mathematics at Tharand, 1840 to 1843) and G. Heyer, son of Carl Heyer, who based his method on his father's formula, merely introducing values for volumes. Judeich, director of the Tharand school, also developed in the sixties a method based upon financial theory which is to attain the highest rate per cent. on the capital invested in forest production. On the basis of survey and subdivision of working blocks composing a felling series, and with a rotation determined by financial calculations with interest accounts, he makes a periodic area division for determining the felling budget in general, and in addition employs the index per cent., as explained, for determining in each allotted stand the more exact time for its harvest.

While these men pleaded for a strict finance calculation, such as is properly applied to any business making financial results the main issue, the defenders of the old regime, which sought the object of forest management mainly in highest material or value production, advanced as their financial program the attainment of the highest forest rent as opposed to the highest soil rent. They neglected and derided the complicated interest calcula- 
tions which have to take into consideration uncertain future developments, and were satisfied with producing a satisfactory balance, a surplus of income over expenses, no matter what interest rate on the capital involved in soil and forest growth that might represent.

At the present time these financial propositions are still merely under heated discussion.

In actual practice'the various state forest administrations, with the exception of the Saxon one, continue to rely upon the older methods in regulating the management of their forest properties without reference to financial theories. This is largely due to momentum of the practical existence and application of these methods in earlier times and the difficulty and impracticability of a change. In Prussia the instructions of Hartig were improved upon by his successor, Oberlandforstmeister von Reuss (1836), and these instructions form the basis of the work of forest regulation to-day. It is a periodic area allotment with only a summary check by volume. The working plan is only to secure a rational location and gradation of age classes; the calculations of yields and specific rules of management are confined to the first period and are revised every six years.

In Saxony Cotta's area method was systematically developed, and, as the larger part of Saxon forests is coniferous, mainly spruce, the proper location of age classes forms a special consideration for the progress of fellings. The determination of volume and increment was left to estimates, and the area division became entirely superior. The original idea of Cotta that orderly procedure in the management is of more importance 
than the actual determination and equalization of yield still pervades the Saxon practice. Since 1860 an attempt has been made to calculate the rotation and determine the felling budget on the principle of the soil rent, at least as a corrective of the annual budget.

In Bavaria, after various changes, a complete allotment method of area and volume has come into vogue.

In Würtemberg, where in 1818 to 1822 a pure volume allotment had been introduced, in 1862 to 1863 the combined allotment method was begun, the felling budget being determined in a general way for the next two or three periods, and more precisely for the first decade, without attempting more than approximate equality.

In Baden, where the forest organization began in 1836 upon the basis of volume allotment, a change was made in 1849 to an area allotment, simplifying to a greater extent than anywhere else the calculation of the yield; finally Heyer's method was adopted entirely in 1869 .

It appears then that the schematic allotment methods found the most general application, being favored probably on account of their simplicity in application in the absence of an easy method of determining volume yield. The improvement in their present application over the original methods as designed by Hartig and Cotta, is that they require no volume calculation for any long future, but are satisfied with making a sufficiently accurate calculation and provision for the proper felling budget for the present.

6. Forest Administration.

About 1750 the recognition of the importance of forestry led to a severance of the hunting and forest inter- 
ests, and it became the practice to place the direction of the latter in the hands of some more or less competent man-a state forester-usually under the fiscal branch or treasury department of the general administration. A fully organized forest administration, in the modern seuse. however, could hardly be said to exist until after the wars of liberation (1815) which had undoubtedly retarded the peaceful development of this as well as of other reforms.

In organizing the large Prussian forest department, for instance, a division into provincial administrations was first established, and these were differcntiated into directive, inspection and executive services. The execution of working plans was conducted by managers of districts $(100,000$ to 125,000 acres $)$ in charge of Oberförster or Revierförster, who with the assistance of several underforesters (Förster) were in charge of the practical work. At first only indifferently educated, they were allowed little latitude, but with improvement in their education they became by degrees more and more independent agents. The direction of this district management, several districts in combination, was in the hands of an Oberforstmeister, with the assistance of a number of Forstmeister, who acted mainly as inspectors.

This tri-partite system of directing, inspecting and executive officers, after various changes in titles and functions finally became practically established in all the larger German states; in some rather lately, as for instance, in Bavaria, not until 1885, and in Wurtemberg in $188 \%$.

With this more stable organization, the character and the status of the personnel changed greatly: the prior 
right of the nobility to the higher positions, which lasted in some States until 1848, and the practice of making connection with military service a basis for appointment were abolished, and, instead of employing Cameralists, educated foresters came everywhere to the head of affairs. The lower service which had been recruited from hunters and lackeys, and which was noted for its low social, moral and pecuniary status, was improved in all directions. Although incidentals in the way of fees and natural instead of money emoluments still play a role even to date, the establishment of definite salaries and the salutary change of methods in transacting business, which Hartig introduced, became general. With the development and importance of forestry schools, the requirement of a higher technical education for positions in State service could be enforced. Yet only within the last twenty-five or thirty years, has the ranking position of forest officers been made adequate and equalized with that of other nofficers of equal responsibility.

The central administration now lies in the hands of technical men (Oberlandforstmeister) with a council of technical deputies (Landforstmeister) all of whom have passed through all the stages of employment from the district managers up. This central office or "division of forestry" is either attached to the department of agriculture, or to that of finance, and has entire charge of the questions of personnel, direction of forest schools, of the forest policy of the administation, and the approval of all working plans, acting in all things pertaining to the forest service as a court of last resort. The working plans are made and revised by special commissioners in each case, or, as in Saxony, under the direction 
of a special bureau, with the assistance of the district manager. Upon the basis of the general working plan prepared by these commissions an annual plan is elaborated by the district managers with consultation and approval of the provincial and central administration. These plans contain a detailed statement of all the work to be done through the year, the cost of each item and the receipts expected from each source. This annual working plan requires approval by the provincial administration, which is constituted as a deliberative council, consisting of a number of Forstmeister with an Oberforstmeister as presiding officer. The titles of these officers, to be sure, and the details of procedure vary somewhat in different states, but the system as a whole is more or less alike.

The district manager or Oberförster, now often called Forstmeister, has grown in importance and freedom of position, although his district has grown smaller (mostly not over 25,000 acres), and, being one of the best educated men in the country district, he usually holds the highest social position, although his emoluments are still small. He holds many offices of an honorary character, as for instance that of justice of the peace, and the position of states attorney or public prosecutor in all cases of infraction of the forest laws. These forest laws are still largely local, that is, State laws, although the criminal law of the empire has somewhat unified practice.

Curiously enough wood on the stump is still not considered property in the same sense as other things, so far as theft is concerned; the stealing of growing timber is not even called theft, the word used in the laws being Frevel (tort), and like other infractions against forest 
laws it is punished by a money fine more or less in proportion to the value of the stolen material or the damage suffered. This money fine may be transmuted into imprisonment or forest labor, but corporal punishment, which still prevailed in the first decades of the century, has been abolished. Wood stealing was very general and rampant during the beginning of the century, but improvement in the condition of the country population and in the number and personnel of the forest officers since 1850 has now reduced it to a minimum.

Formerly, and until 1818, the administrators and even the forest owners acted at the same time as prosecutor, judge and executioner, and only in 1879 was this condition everywhere and entirely changed and infractions against forest laws adjudged by regular courts of law, holding meetings at stated times for the prosecution of such infractions.

Nevertheless the court procedures in forest matters still vary from the usual court practice, providing a simpler, cheaper and more ready disposal of testimony and witnesses, and quicker retribution, which is largely rendered possible through having every forest officer under oath as a sheriff, and his statement and perhaps the confiscated tools employed in the theft, being accepted as prima facie evidence of the infraction.

The social position of the underforesters and the forest protective service has also been improved until all charges of incompetency and immorality which were not undeserved even until past the middle of the nineteenth century, have become reversed; the forest service being morally on as high a plane as all the departments of German administrations. 


\section{\%. Forest Policy.}

During the first half of the century the old concep- $\checkmark$ tion of Forsthoheit-superior right of the princes to supervise and interfere with private property-changed into the more modern conception of the police function of the state, and by 1850 , after the revolutionary period, the seignorage of the princes had passed away. The issue of forest ordinances (the last in 1840) was replaced by the enactment of forest laws which, since the establishment of representative government, has become a duty of the legislators.

The tendency to restrict the exercise of private property rights had been assailed by the theories of Laissez faire and the teachings of Adam Smith, and as a consequence all the restrictive mandates of the older forest ordinances had been weakened and had more or less fallen into disuse. Especially the attempts to influence prices and markets had nearly if not entirely vanished during the first decade. Only for the state forest it was still thought desirable to predetermine prices, or at least keep to low rates, because wood was a necessary material for the industries. This theory prerailed until, perhaps under the lead of Hundeshagen (see above), the propriety of securing the highest soil rent was recognized as the proper aim, when the practice of selling wood at auction in order to secure the best prices became the rule.

The regulations of export and import between the different States, which had been enacted under the mercantilistic teachings of the last century (see page 49), and the many local tariffs which impeded a free exchange of commodities, lasted for a long while and were not all abolished until 1865, when under the lead of 
Prussia, the North German Federation instituted the Zollverein (Tariff alliance). Import duties were, however, again established in 1879 , and the policy of protecting the established organized forest management against competition by importations from exploiting countries has been more and more recognized as proper in the revision of tariff rates and railroad freight rates on the government railroads.

During the first decades of the century, the supply question was uppermost, and although such men as Pfeil (1816) laughed at the idea of a wood famine, there was good reason, prior to the development of railroads, of coal fields, of iron and steel manufactures, etc., for discussing with apprehension the area and condition of supply and the extent of the consumption. Nevertheless the attitude of the state toward private property was much more influenced by the economic theories then prevalent, which taught the ideas of private liberty to which the French Revolution had given such forcible expression.

With the change of the different municipal communities into units or parts of political or state machines, whereby independence in the management of their property was secured, many of the old restrictions fell away. Curiously enough, during the French domination under Napoleon, the new masters, forgetting the spirit of the revolutionary period, introduced the prescriptions of the old French ordinance of 1669 which restricted the use of communal property to the extent of excluding the owners entirely from the management of their property, placing it under government officers. After the French withdrew, this method, of course, collapsed, although it 
probably had an influence on the final shaping of forest policies in these respects. Altogether there was such variety of historic development in the different parts of Germany that it is not to be wondered at that one finds a great variety of policies still prevailing.

At the present time three different principles in the relations of the state to the corporation forests may be recognized, namely, entire freedom, excepting so far as general police laws apply, which is the case with most of the corporation forests in Prussia (law of 1876) ; special supervision of the technical management under approved officials with proper education, which is the case in Saxony, most of Bavaria, the Prussian provinces of Westphalia, Rhineland and Saxony, and some of the smaller states; or lastly, the absolute administration by the state, which prevails in Baden, parts of Bavaria, provinces Hesse, Nassau, and Hanover. The tendency, however, in modern times appears to be toward a more strict interpretation of the obligation of the state to prevent mismanagement of the communal property.

The private forest property, which during the preceding century had been largely under restrictions, first under the application of the hunting right, and then under the fear of a wood famine, became in the first decades of the century under the influences already mentioned, almost entirely free, all former policies being reversed; indeed Prussia in 1811 issued an edict insuring absolute unrestricted rights to forest owners, permitting partition and conversion of forest properties and even denying in such cases interference on the part of possessors of rights of user.

This policy of freedom was also applied, although less 
radically, in Bavaria, except as to smaller owners. The result was, to a large extent, the increase of exploitation and forest devastation, creating wastes and setting shifting sand and sanddunes in motion. The reaction which set in resulted in Prussia not in renewal of restrictive measures, but in the enactment of promotive ones. The law of 1875 sought improvement by encouraging small owners to unite their properties under one management; but the expectations which were founded on this ameliorative policy seem so far not to have been realized.

A new relation, however, of a conservative character arose by the establishment of the entail, that is a contract made by the head of the family with the government under which the latter assumes the obligation of forever preventing the heirs from disposing of, diminishing or mismanaging their property. As a result of this arrangement, many of the larger private forest properties are forced to a conservative management, not as a direct influence of the law, but as a matter of agreement. The condition of the relation of the state to private and communal forest property at present prevailing is expressed in the following statement of divisions by property classes of forest areas of Germany, showing that at least $63.9 \%$ are under conservative management:

Total Forest .......34,769,794 acres.

Crown forest ............. 1.8\%

State forest ................ $31.9 \%$

Corporation forest ..........16.1\%

Institute forest . ............ 1.5\%

Association forest ...........2.2\%

Private forest (10.4\% entail) ...46.5\% 
Until the beginning of the present century the protective function of the forest had played no role in the arguments for state interference, but just about the beginning of the century cries were heard from France that owing to the reckless devastation of the Vosges and Jura Alps by cutting, by fires and overgrazing, the brooks had become torrents and the vallevs were inundated and covered by the debris and silt of the torrents. A new aspect of the results of forest devastation began to be recognized, which found excellent expression in a memoir by Moreau de Jonnés (Brussels, 1825), on the question "What changes does denudation effect on the physical condition of the country." This being translated by Wiedenmann, was widely spread, being interestingly written, although not well founded on facts of natural history and physical laws. Nevertheless, sufficient experience as regards the effect of denudation in mountainous countries had also accumulated in southwest Germany and in the Austrian Alps, and the necessity of protective legislation was recognized. This necessity first found practical expression in the Bavarian law of 1852, in Prussia in 1875 and Würtemberg in 1879. But a really proper basis for formulating a policy or argument for protective legislation outside of the mountainous country is still absent, although for a number of years attempts have been made to secure such basis.

\section{Forestry Science and Literature.*}

The habit of writing encyclopædic volumes, which the Cameralists and learned hunters had inaugurated in the

*The necessarily brief statements which are made under this heading pre suppose knowledge of the technical detai's to which they refer. In this short history it was possible only to sketch rapidly the development of the science in terms familiar to the profeasional man. 
preceding century, continued into the new one, and we find Hartig, Cotta, Pfeil and Hundeshagen each writing such encyclopædias. Carl Heyer began one in separate volumes, but completed only two of them. Even an encyclopædic work in monographs by several authors was undertaken as early as 1819 by J. M. Bechstein, who with his successors brought out fourteen volumes, covering the ground pretty fully. While in the earlier stages the meager amount of knowledge made it possible to compress the whole into small compass, the more modern encyclopædias of Lorey, Fürst and Dombrowski arose from the opposite consideration, namely, the need of giving a comprehensive survey of the large mass of accumulated knowledge.

Since 1820 monographic writings, however, became more and more the practice. Among the volumes which treat certain branches of forestry monographically, the works of the masters of silviculture, Cotta, Hartig and Heyer, based on their experiences in west and middle Germany, and of Pfeil, referring more particularly to North German conditions, were followed by the South

$\checkmark$ German writers, Gwinner (1834), and Stump (1849). In $1855 \mathrm{H}$. Burkhardt introduced in his classic Säen und Pfanzen a new method of treatment, namely, by species, and after 1850 when the development of general silviculture had been accomplished, such treatment by species became frequent. Of more modern works on general silviculture elaborating the attempts at reform of old practices those of Gayer (1880) Borggreve, Wagener, Ney, all writing about the same decade are to be especially mentioned. In this connection should be noticed also Fürst's valuable collective work on 
nursery practice by species (Pflanzenzucht im Walde, 1882).

At present the magazine literature furnishes ample opportunity to discuss the development of methods in all directions. The text books at present appearing seem to be justified by or intended mainly for the needs of the teacher and rarely for the practitioner. Such a text book is that by Weise.

Other branches than silviculture were similarly first treated in comprehensive volumes and then in monographic writings on special subjects of the branch. The literature on forest utilization covering the whole field, was enriched especially by Pfeil, Koenig, Gayer, and Fürst. The first investigation into the physical and technical properties of wood was conducted by $G$. $L$. Hartig himself followed by Theodor Hartig, and has been most broadly treated by $H$. Noerdlinger (1860).

The question of means of transportation gradually became also a subject capable of monographic treatment and a series of books came out on locating and building forest roads. Braun issued such a book in 1855 for the plains country and Kaiser (18:3) for the mountains, also Mühthausen (18\%6), who had been commissioned to locate a perfect road system over the demonstration forest at the forest academy of Muenden. Only within the last quarter of the century were railroads introduced into the economy of forest management. The first comprehensive book on the subject of logging roads was issued by Foerster, and a later one by Runnebaum.

A very comprehensive literature on the value of forest litter was brought into existence by the established usage of small farmers of supplying their lack of straw for 
bedding and manure by substituting the litter raked from the forest. Hartig and Hundeshagen were active in the discussion of this subject as well as almost every other forester, the discussion being, however, mainly based on opinions. But after 1860 the subject became so important both to the poor farming population and to the forest, which was being robbed of its natural fertilizer, that a more definite basis for regulating its use was established by analysis and by experiments at the experimental stations.

With the inauguration of the various methods of forest organization described before, there naturally went hand in hand the development of methods of measurement. Better forest surveys developed rapidly, the transit generally replacing the compass and plane table. At this period the necessity for books teaching the important methods of land survey was met by Baur (1858) and by Krafft (1865). This subject does no longer occupy a place in forestry literature, the knowledge of it being taken for granted.

On the other hand the subject of forest mensuration which formerly was generally treated in connection with forest organization has developed into a branch by itself and has been very considerably developed in its methods and instruments, making a tolerably accurate measurement of forest growth possible, although many unsolved problems are still under investigation. Still late into the century it was customary to measure only circumferences of trees by means of a chain or band, although an instrument for measuring diameters is mentioned by Cotta in 1804 and by Hartig, 1808. Schoener and Richter are in 1813 described as inventors of the first "uni- 
versal forest measure" or caliper. The improvement of calipers to their modern efficiency has been carried on since 1840 by Carl and Gustav Heyer and by many others until now a self-recording caliper (by Reuss, etc.) has become a practical instrument. For measuring the heights of trees, Hossfeld had already a satisfactory instrument in 1800 , a very large number of improvements in great variety having followed, with Faustmann's mirror hypsometer probably in the lead. As a special development for measuring diameters at rarying heights Pressler's instrument should be mentioned, and a very complicated but extremely accurate one constructed by Breymann.

Various formulas for the computation of the contents of felled trees had already been developed by Oet telt and others in the eighteenth century and a formula by Huber, using the average area multiplied by length was definitely introduced in the Prussian practice in 181\%. The names of Smalian, Hossfeld, Pressler and others are connected with improvements in these directions.

The idea of form factors and their nse was first developed by Huber, who made three tree classes, according to the length of crowns, measured the diameters six feet above ground, and used reduction factors of .75, .66, 50 for the three classes. But the first formula for determining form factors is credited to Hossfeld (1812) and Hundeshagen and Koenig occupied themselves with elaborating form factors. Smalian (183\%) introduced the conception of the normal or true form factor relating it to the area at one-twentieth of the height. An entirely new idea has lately been introduced by Schiffel 
under the name of form quotient, placing two measured diameters in relation.

Volume tables giving the volumes of trees of varying diameters and height were already in use to some extent in the 18th century; Cotta gives such for beech in 1804, and in 1817 furnished a new set of so-called normal tables which were however based upon the assumption of a conical form of the tree. Koenig perfected volume tables by introducing further classification into five growth classes (1813), published volume tables for beech and other species and in 1840 published volume tables not for single trees but for entire stands per acre classified by species, height and density; using the so-called distance number which he had developed in 1835 to denote the density. It is interesting to note that these tables which he called Allgemeine Waldschætzungstafeln were made for the Imperial Russian Society for the Advancement of Forestry.

In 1840 and succeeding years the Bavarian government issued a comprehensive series of measurements and a large number of form factors which were used in constructing volume tables; these were found to be so well made and so generally applicable that they were used in all parts of Germany and, translated into meter measurement by Behm (18\%2), are still generally in use, although new ones based upon further measurements have been furnished by Lorey and Kuntze.

For arriving at the volume of stands, estimates were relied upon long into the nineteenth century, although Hossfeld in 1812 introduced a formula by the use of AHF in which A was the measured total cross-section area of the stand, $\mathrm{H}$ and $\mathrm{F}$ the height and form factors, 
being estimated at that time. He still made form classes for the same heights, but in 1823 simplified the method by assuming an average form factor for the whole stand. Even in 1830 Konig still estimated the form factor, although he introduced the measurement of the cross-section area and determined the height indirectly as an average of measurement of several height classes, -but Huber (1824) knew how to measure both the average height and form factor by means of an arithmetic sample tree. This method found entrance into the practice and held sway until about 1860 when the well-known improvements by Draudt and Urich supplanted it. These last mentioned methods have become generally used in the practice while other methods like R. Hartig's and Pressler's have remained mainly theoretical.

The study of the increment and the making of yield tables which had been inaugurated by Oetellt, Paulsen, Hartig and others toward the end of the last century, was just at the end of that century placed upon a new basis through Späth (1797), who constructed the first growth curves by plotting the eubic contents of trees of different ages, and through Seutter (1799) by introducing stem analysis, on which he based his yield tables.

On the shoulders of these did Hossfeld (1823) build, when he conceired the idea of using sample plots for continued observation of the progress of increment and also taught the method of interpolation with limited measurements, laying the basis for quite elaborate formulæ. But the first normal yield tables, based on the average trees of an index stand, were published by Huber (1824) and in the same year by Hundeshagen. From that time 
on yield tables were constructed by many others, but only since the Experiment stations undertook to direct their construction is the hope justified of securing this most invaluable tool of forest management in reliable and sufficiently detailed form. Even the newest tables are, however, still deficient, especially in the direction of detailed information regarding the division into assortments. The yield tables of Baur, Kuntze, Weise, Lorey and others are now superseded by those of Schwappach for pine and spruce, and of Schuberg for fir.

As a result of the many yield tables which gradually accumulated, the laws of growth in general became more and more cleared up and finally permitted their formulation as undertaken by $R$. Weber (Forsteinrichtung, 1891).

The idea of using the percentic relations for stating the increment, and of estimating the future growth upon the basis of past performance for single trees was known even to Hartig (1795) and Cotta (1804) who published increment per cent. tables. The methods of making the measurements of increment on standing trees were especially elaborated by Koenig, Karl, Edward and Gustav Heyer, Schneider, Jaeger, Borggreve and especially by Pressler (1860) who opened new points of view and increased the means of studying increment by causing the construction of the well-known increment borer and in other ways.

The most modern text-book which treats fully of all modern methods of forest mensuration giving also their history is that of $U$ do Müller (Lehrbuch der Holzmesskunde, 1899), superseding such other good ones, as those of Baur (1860-1882), Kuntze (1873), Schwappach (short handbook, last edition 1903). 
The many sales of forest property which took place at the beginning of this period naturally stimulated the elaboration of methods of forest valuation. Even the soil rent theory finds its basis at the very beginning (1799) in a published letter by two otherwise unknown foresters (Bein and Eyber), who proposed to determine the value of a forest by discounting the worth of the net yield with a limited compound interest calculation to the 120th year. This idea was elaborated in 1805 by Nordlinger and Hossfeld into the modern conception of expectancy values and the now familiar discount calculations were inaugurated by them. Cotta and Hartig participated also in the elaboration of methods of forest $\mathrm{val}$ uation; Cotta writing his manual in 1804, recognizes the propriety of compound interest calculations, while Hartig, 1812, still uses only simple interest and exhibits in his book as well as in his instructions for practice in the Prussian state forests rather mixed notions on the subject.

Altogether, even in the earlier part of the period, there arose considerable difference of opinion and warm. discussions, in which all the prominent foresters took part, as to the use of interest rates and methods of calculation. But this warfare broke into a red hot flame When Faustmann (1849) with much mathematical apparatus developed his formula for the soil expectancy ralue, and when Pressler and G. Heyer transferred the discussion into statical fields making the question of the financial rotation the issue. Then the adrocates of the soil rent and of the forest rent theories ranged themselves in opposite camps. This war of opinions, although abated in fervor, still continues and the issue is by no means settled. 
The discussion of what should be considered the proper felling age or rotation naturally occupied the minds of foresters from early times; a maximum volume production being originally the main aim. As early as 1799, Seutter had recognized the fact that the culmination of volume production had been obtained when the average accretion had culminated. Hartig, in 1808, made the distinction of a physical, an economic and a mercantilistic, i. e., financial felling age, and Pfeil, considerably ahead of his time is the first to call (1820) for a rotation based on maximum soil rent. As, however, he had so often done, he changed his mind, and while he first advocated even for the state a management for the highest interest on the soil capital involved, he later rejected such money management. About the same time Hundeshagen clearly pointed out the propriety and proper method of basing the rotation on profit calculations, but it was reserved for a man not a forester to stir up the modern strife for the proper financial basis, namely Pressler, a professor of mathematics at Tharand, who became a sharp critic of existing forest management and developed to the extreme the net yield theories.

It was then that the danger of a shortening of the existing rotations, due to the apparent truth that long rotations were unprofitable, called for a division into the two camps alluded to; G. Heyer, Judeich and Lehr, elaborating especially the mathematical methods of the soil rent theory, Krafft and Wagener came to the assistance of Pressler, while Burkhardt, Bose, Baur, Borggreve, Dankelmann, Fischbach and others, pleaded for a different policy for the state at least, namely, the forest rent with the established rotations. 
As in the previous period the mathematical subjects, namely, forest measurement and forest valuation, were more systematically developed than the natural history basis of forestry practice; the slower progress of the latter being caused by the greater difficulties of studying natural history and of utilizing direct observation.

In botanical direction descriptive forest botany was first developed and several good books were published by Walther, Borkhausen, Bechstein, Reum, the latter (1814), of high value, and also by Behlen, Gwinner and Hartig.

In the direction of plant physiology Cotta early and creditably attempted (1806) to explain the movement and function of sap, but remained unnoticed. Mayer's (1805-1808) essay on the influence of the natural forces on the growth and nutrition of trees, contains interesting physiological explanations for advanced silvicultural practice. But these sporadic attempts to secure a biological basis were soon forgotten. Not until Theodor Hartig (1878) published his Anatomy and Physiology of Woody Plants was the necessity for exact investigation of forest biology as a basis for silvicultural practice fully recognized. With the development of general biological botany or ecology a new era for silviculture seems to have arrived. Perhaps in this connection there should be mentioned as one of the earlier important contributions of much moment, $G$. Heyer's Verhalten der Bäume gegen Licht und Schatten (1856) in which the theory of influence of light and shade on forest development was elaborated.

Among those who placed the study of pathology of forest trees on a scientific basis should be mentioned first Willkomm (1876), followed by $R$. Hartig. 
In zoölogy the early writers began with a description of the biology of game animals. Next, interest in forest insects became natural and in 1818 Bechstein in his Encyclopædia devoted one volume (by Scharfenberg) to the natural history of obnoxious forest insects. Toward the middle of the century with the cultivation of forests and especially the planting of large areas with single species, insect pests increased, hence the interest in the life histories of the pests grew and gave rise to the celebrated work by Ratzeburg, "Die Waldverderber und Ihre Feinde" (1841). A number of similar hand-books on insects and on other zoölogical subjects followed; the last, a most complete work on insects, being still based on Ratzeburg's work is that of Judeich and Nitzsche, in two volumes (1895). Of course, the general works on forest protection always included chapters on forest entomology. The first of these text-books on forest protection was published by Laurop (1811), and others by Bechstein, Pfeil, Kauschinger and recently by Hess (1896), and Fürst (1889).

Knowledge of the soil was but poorly developed in the encycloprdic works of the earlier part of the period.

Not till Liebig's epochmaking investigations was a scientific basis secured for the subject. Then became possible the improvements in the contents of such works as Grebe (1886), Senft (1888), and of Gustav Heyer, whose volume (Lehrbuch der Forstlichen Bodenkunde und Klimatologie, 1856), well records the state of knowledge at that time. But only since then has this field been worked with more scientific thoroughness by Ebermayer, Schroder, Weber, Wollny and by Ramann, 
whose volume on Bodenkunde (1893) may be considered the standard of the present day.

The question of the climatic significance of forests is one which first became recognized as capable of solution by scientific means when the movement for forest experiment stations began to take shape and the systematic collecting of observed data was attempted. Most of the problems are still unsolved.

With the aspects of political economy in reference to forest policy the foresters had occupied themselves but little, leaving the shaping of public opinion to the Cameralists, whose influence lasted long into the century. These produced a good deal of literature in the early years of the century when the question of retaining or selling state forests was under discussion, and, under the influence of the teachings of Adam Smith, their opinion was mostly favorable to sale. Only gradually was the propriety of state forests recognized by them, till finally the leading economists, Rau, Roscher and Wagner, took a decided stand in favor of this view.

The foresters naturally were for retention of the existing State properties, but one-sided mereantilistic views regarding their administration persisted with them till modern times.

Wedekind as early as 1821 adrocated the theory which is now becoming a practice, that the state should not only retain, but increase its present forest property by purchase of all absolute forest soil for the purpose of reforestation. The erratic and radical Pfeil alone was found with the Cameralists on the opposite side in $\mathbf{1 8 1 6}$, but by 1834 he had entirely gone over to the side of the 
advocates of state forest, declaring anyone who opposed them fit for the lunatic asylum.

Division of opinions existed also regarding the supervision by the state of private and communal forests. The political economists were inclined to reduce, the foresters to increase supervision, excepting again Pfeil in his earlier writings; he modified his views later by recognizing supervision as a necessary evil. Cotta, who was inclined to favor free use of forest property sought to meet the objections to such free use by increasing the state property. The main incentive urged by the earlier advocates of state supervision was the fear of a timber famine. This argument vanished, however, with the development of railroads and was then supplanted by the argument of the protective functions of the forest, a classification into supply forests and protective forests suggesting differences of treatment. Nevertheless the belief that absolute freedom of property rights in forest is not in harmony with good political economy-a belief correct because of the long time element involved-still largely prevails. The difficulty, however, of supervising private ownership and the advantages of state ownership find definite expression in the policy which Prussia especially is now following, in acquiring gradually the mismanaged private woodlands and impoverished farm areas for reforestation, making annual appropriations to this end. Many other states also are beginning to see the propriety of this morement.

On the whole the systematic study of the economics of forestry has been rather neglected by foresters, although the subject was discussed by early writers, Meyer, Laurop, Pfeil, and in modern times by $R$. Weber, Lehr and Schwappach ("Forstpolitik," 1894). 


\section{Means of Advancing Forestry Science.}

During the century the means of increasing knowledge in forestry matters have grown in all directions, schools, associations, journals and prolific literature attesting the complete establishment of the profession and practice.

The master schools which began to take shape at the end of the last century and a number of which were found in the beginning of the century as private institutions were usually either of short duration or were changed into state institutions: they became either "middle schools" for the lower service, or else academies. For the higher education the chairs of forestry at the universities continued to do service, as at Heidelberg, Giessen, Leipzig, Berlin, etc., but as these were mostly occupied by Cameralists (although Hartig in 1811 filled a chair at Berlin), and were intended for the benefit of such rather than of professional foresters, the education of the latter was somewhat neglected. Most of the existing institutions had their beginnings in private schools. Both these and the state schools passed through many changes. The first high class forest academy was established directly by the state at Berlin, 1821 , in connection with the university, where Pfeil was the only professor, the other subjects being taught by other university professors. The fact that a demonstration forest was not easily accessible in the absence of railroads, and perhaps the friction between Pfeil and Hartig brought about a transfer to Neustadt-Eberswalde, in 1830 , with two professors till 1851, when a third professor was added (now 16 with 8 assistants!). At the same time the lectures at Berlin under Hartig continued until $183 \%$. 
In Saxony Cotta's private school became a state institution in 1816, the forest academy of Tharand, with six teachers (now 11), and later, in 1830, an agricultural school was added to it. In Bavaria a private school was begun in 1807 at Aschaffenburg. It was made a state institution, divided into a higher and lower school, in 1819, but was closed in 1832 on account of interior troubles and inefficiency. It was reopened and reorganized in 1844 with four teachers, and was intended to prepare for the lower grades of the service. Meanwhile the lectures at the University of Munich, supplementing this lower school, were to serve for the education of the higher grades. The reorganization took place in 1878, when a special faculty for forestry was established with Gustav Heyer as head professor. This was done after much discussion, which is still going on throughout the empire, as to the question whether education in forestry was best obtained at a university or at a special academy. The present tendency is toward the former solution of the question since railroad development has removed the main objection, namely, the difficulty of reaching a demonstration forest. Nevertheless Prussia retains its two forest academies Eberswalde and Münden (since 1868) for the education of its forest officials, the other state academies being at Tharand and Eisenach, while chairs of forestry are found at the universities of Tübingen (since 181\%), Giessen (since 1831), and Munich, and for Baden at the polytechnicum in Karlsruhe (1832). For the lower grades of forest officials there are also schools established by the various governments ( 3 in Prussia, 5 in Bavaria).

Although as early as 1820 Hundeshagen had in- 
sisted upon the necessity of exact investigation to form a basis of improved forest management and especially of forest statics, and although in 1848 Carl Heyer elaborated the first instruction for such investigations which he expected to carry on with the aid of practitioners, the apathy of the latter and the troublesome times prior to 1850 retarded this powerful means of advancing forestry. During the decade from 1860 to 1870 , however, the movement for the formation of experiment stations took shape, the first set being instituted in Saxony, 1862, by establishing nine stations for the purpose of securing forest meteorological data, the next in Prussia in 1865 to solve the problems of the removal of litter, and in Bavaria (1866), also for the study of forest meteorology (Ebermayer), and the problem of thinnings. But not until Baur 1868, had pointed out more elaborately the necessity of systematic investigations and a plan for such had been elaborated by a committee instituted by the German Forestry Association was a system of experimentation as organized in modern times secured (1872). The various states established independently such experiment stations, but at the same time a voluntary association of these stations was formed for the purpose of co-ordinating and planning the work to be done.

Forestry associations instituted merely for the purpose of propaganda, were apparently not organized. The first association of professional foresters appears to have been formed as the result of Bechstein's conception, who proposed in connection with his school (1795 at Gotha, 1800 at Dreissigacker) the formation of an academy of noted foresters. As the result the Societät 
der Forst und Jagdkunde was formed in which all the noted foresters joined with much enthusiasm, and in 1801, a membership of 81 regular and 61 honorary members was attained. At the same time the official organ Diana was founded (1797), in which the essays of the members were to be printed, after having passed four censors. Two sessions were to be held annually. This much too elaborate plan for the then rather undeveloped education and means of transportation defeated to some extent the great object. By 1812 it was thought necessary to divide the academy at least into a northern and southern section, and for the latter an additional journal edited by Laurop was instituted. The interest, however, decreased continually and by 1843, at Bechstein's death, the academy was abandoned.

At the same time there had sprung up a number of local associations in the modern sense. The first in 1820 , composed of the foresters and agriculturists of Nassau; the next in 1839, of the foresters of Baden, and. by 1860 nine such local societies of foresters were in existence and they have since increased rapidly until now some thirty may be counted. The desire to bring these local associations into relation to each other led to the first Forestry Congress in 1837 (Congress der Landund Forstwirthe), meeting at Dresden. At that time and in the congresses following, the agriculturists played a leading part, so that in 1839 the South German foresters separated, and peripatetic congresses were held every one or two years. In 1869 a general organization was determined upon, and in 1872 the first general German Congress of Foresters met, holding yearly meetings thereafter. A rival association having been 
organized in 1897, two years later an amalgamation of the two was effected in the Deutscher Forstverein (now over 2000 members). The most striking feature of this forceful means of advancing forestry is the institution of the Forstwirtschaftsrat, a permanent committee of about 50 members, which is to look after the political and economic interests of forestry.

There also exists an international association of forest experiment stations.

In the magazine literature the Cameralists dominated until the eighteenth century. The first journal edited by a forester was Reitter's "Journal für Forst und Jagdwesen" which ran from 1790 to 179\%. During the first part of the century many others were started, especially after 1820, usually failing soon for lack of support. Hartig himself participated in this literature with five volumes (until 1807) of the Journal des Forst-Jagd-und Fischereiwesens and later (1816 to 1820) with the semi-official journal Forst und Jagdarchiv. Pfeil's Kritische Blätter were continued by him from 1823 to 1859 , when Nördlinger had the editorship till 1870. An irregular publication of much note was Burkhardt's Aus dem Walde" (1865-1881).

Some of the journals founded in earlier times have continued with changes in title and editorships to the present day. Of these it is proper to mention as the oldest, "Allgemeine Forst und Jagdzeitung, founded by v. Behlen, 1825, later conducted by G. Heyer; "Forstwissenschaftliches Centralblatt" (1828); "Zeitschrift für Forst und Jagdwesen" founded in 1869 by Dankelmann; "Forstliche Blätter" founded 1861 by Grunert, continued by Borggreve until 1890. The Tharandter 
Forstliche Jahrbücher were begun in 1842, and the Mündener Forstliche Hefte in 1892. In 1893 the Forstlich-naturwissenschaftliche Z eitschrift was established to discuss mainly the biological basis of forestry (changed in 1903 to Naturwissenschaftliche Z eitschrift für Land-und Forstwesen).

For the lower grades there has been published since 1872 Zeitschrift der deutschen Forstbeamten. Several lumber trade journals also discuss forestry matters.

To assist in keeping track of the historic and scientific development of the art, an annual summary of magazine literature is being published. The first effort in this direction was made in $18 \% 6$ by Bernhardt's Chronit des deutschen Forstwesens, which was continued for several years, but is now supplanted by Jahresbericht über die Leistungen und Fortschritte der Forstwirthschaft (since 1880).

Besides this more scientific magazine literature, "Pocket Books" and "Calendars" have been published from early times, the regular annual appearance of the latter, giving detailed statistics, personalia, tables useful in the practice, etc., dates from 1851.

With the accomplishment of the unity of the empire in 18\%1, with the establishment of the Experiment Stations and their association in 1872 , and with the organization of the Society of German Foresters, which dates from the same year, a new and most active era in the development of forestry science may be recognized, the tendency of which is to lift the art out of the shackles of empiricism and place it on a more scientific basis. 


\section{AUSTRIA-HUNGARY.}

Germany's neighbor to the south-east, and until 1866 a member of the German Empire or Federation, largely settled by Germans, and hence swayed by German thought, developed forestry methods on much the same lines as the mother country. Yet there are differences to be found, due to difference in economic development, and there is for the United States perhaps more to be learned from Austria in the matter of introducing forestry methods, especially as lately practiced in BosniaHerzegovina, than from any other country, for economic conditions are in several respects alike.

The interest in the forest history of Austria lies especially in the fact that private forest property in large

Zur Forstgeschickte Oesterreichs, by BINDER VON KRIEGELSTEIN, in Verhandlungen der K. K. Landwirthschaftsgesellschaft, 1836.

Geschichte der Oesterreichischen Land-und Forstwirtschaft wnd ihrer Industrieen, $18, \& \&-1 \$ 98$. 5 vols., 1902, parts referring to forestry, vols. 4 and 5 , by Dr. von Guttenberg and 15 others ; a unique, and most comprehensive work, magnificently published as a jubilee of the semicentennial of the coronation of Fimperor Franz Joseph.

Die Forste der Staats-and Fondsgiter, by KARL SCHINDLER, 1885 and 1889,2 vols., pp. 487 and 742 , contains in greatest detall with historical data a description of the State and Funds forests and their management.

Jahrbuck der Staats-und Fondsgiter-veravaltung, 9 vols, by L. Dimrtz. 1897-1804 cont.

Urkundemsammlwng sur Geschichte der wngarischen Forstwirthschaft by ALBERT $\vee$. BEDÖ, 1896, in Magyar.

Die Wirthschaftlichen und Kommersiellen Beschreibungen der Wdider des Ungariscken Staates, by A. v. BEDÖ, 2d edition, 1896, 4 vols, 2242 pp., $4^{\circ}$ published as a jubilee of the ten-centennial existence of Hungary. First volume contains the general description, third volume the details of government forests. A magnificent work describing in detail the forests and forest managenent of Hungary. This is briefed by the same author in a chapter in "The Millewimm of Humgary ared its People, by Jexislfalussy, 1897." 
holdings is predominant, and that large areas are still untouched or just opened to exploitation, so that Austria is still in the list of export countries, although in some parts intensive management has been long in existence.

In the main, although movements for reform in forest use date back to the middle ages, the condition of forestry in Austria was still past the middle of the 19th century most deplorable, and in a stage of development which most of the German States had passed long before; but in the last 50 years such progress has been made that both science and practice stand nearly if not quite on the same level with those of their German neighbors.

If Germany exhibits in its different parts a great variety of development, political and economic, Austria, although long under one family of rulers (since 1526), exhibits a still greater variety due to racial, natural and historical differences within its own borders. It is indeed an extraordinary and singular country, without an equal of its kind (except perhaps Turkey) in that it is not a national, but a dynastic power composed of unrelated states or lands, with people speaking different languages, mixed races widely different in character. These were gradually aggregated under one head or ruling family, the Hapsburgs, who as Archdukes of Austria having occupied the elective position of German Emperors for several generations, after the collapse of the Empire in 1806, retained the title and called themselves Emperors of Austria.

The Kingdom of Hungary alone (which was joined to the Hapsburg dominions by election of its people in 1526 , and under new relations in 1867), with at least $50 \%$ Hungarians, is a national unit with a national lan- 
grage (Magyar), while all other parts have in their composition preponderatingly Slavish population, although German elements have the ascendency more or less everywhere.

Not less than 10 different languages are spoken among the forty odd million people of which the Germans comprise about one-quarter, the Hungarians one-third, the balance being Slavs.

Originally this section of the country was occupied by Germans with the German institution of the Mark, but when the Slavish and Magyar tribes pressed in from the East it became the meeting ground of the three races, and during the first 1,000 years after Christ the "East Mark" formed the bulwark of the German empire against the eastern invaders who were in succession, the Slavs, the Huns, the Turks.

With the unexpected election of Rudolph of Hapsburg, a little known prince of small possessions, to the dignity of German Emperor in 1272, the foundation of the Austrian Empire was laid. The Archduchy of Austria he secured by conquest in 1282, and around this nucleus all the other territories were aggregated by the Hapsburgs from time to time, through marriage, conquest or treaty. At one time their rule extended over Spain, the Netherlands, Switzerland, Naples, Sicily and Sardinia.

The abdication of Francis II, in the year 1806, prepared the separation from Germany, although Austrian influence persisted in Germany until 1866 when by the crushing defeat suffered at the hands of Prussia, its place and voice was permanently excluded, and by arrangement with Hungary the new dual empire of Aus- 
tria-Hungary came into existence and gave a new national life and new policies to the coalition which is to amalgamate these southeastern territories into a homogeneous nation.

By the treaty of Berlin in 1878, this territory of 241 942 square miles with over 45 million people was further increased by the addition of the Turkish provinces of Bosnia and Herzegovina with 1,250,000 inhabitants and 23.262 square miles.

It is natural that, corresponding to this great diversity of ethnological elements and historical development, we should find a great variety of forest conditions and uneven development of forestry. While in Bohemia, Moravia and Silesia the most intensive management has long been practiced, in the Carpathians of Galicia and in Hungary rough exploitation is still the rule, and in other parts large untouched forest areas still await development.

We can distinguish at least seven regions thus differently developed: the Northwest with Bohemia, Moravia and the remaining part of Silesia, settled the longest and the longest under forest management; the Northeast, Galicia with the Carpathian. Mountains still largely either exploited or untouched; the Danube lands or Austria proper, with the Vienna forest and the forests connected with the saltworks in Upper Austria and Styria, under some management since the 12 th and 16 th centuries respectively; the Alp territory, including Tyrol and Salzburg, parts of Styria, Karinthia and Krain, much devastated long ago and offering all the problems of the reboisement work of France; the Coast lands 
along the Adriatic with Dalmatia, Istria and Trieste, which, from ancient times under Venetian rule, bring with them the inheritance of a mismanaged limestone country, creating the problems of the "Karst" reforestation which has baffled the economist and forester until the present time; the two new provinces east of this region, Bosnia and Herzegovina, whose rich forest areas have only lately begun to be treated under modern conservative ideas; and finally Hungary with a great variety of conditions in itself.

The large forest per cent. (over $32 \%$ of the land area) is due to the mountainous character of the country, the Alps occupying a large area on the west and southwest, the Carpathians stretching for 600 miles on the northeast, various mountain ranges encircling Bohemia, the Sudetes forming part of the northern frontier, and the Wiener Wald besides other lower ranges being distributed over the empire and bounding the fertile valleys of the Danube and its tributaries. At least 20 per cent. is unproductive.

Hungary is mainly a fertile plain, traversed by the Danube and Theiss, an agricultural country, with the forest confined to the hilly portions to the mountainous southern provinces of Slavonia and Croatia and to the Carpathians, which bound it on the north and east. Nevertheless, while wood in the plain is scarce, the total forest area is but little less than that of Austria proper, namely, 23,000,000 acres (28\%). Large areas of shifting sands, and along the Danube and Theiss rivers swamps, partly created by deforestation, are interspersed with the heavy black prairie and compact clay-soils. The climate in the northern portion of Austria proper 
is similar to that of southern Germany; in the southern portions to that of Italy, while.Hungary partakes of the characteristics of a continental plains climate with low rainfall and extreme temperature ranges.

In addition to the tree species found in Germany there are of economic value four species of pine (Pinus Austriaca, Cembra, Pinea, halepensis), two oaks (Quercus ilex and suber), and the chestnut (Castanea vesca). Conifer forest is prevailing in Austria (with $82 \%$ ), deciduous forest in Hungary, mostly beech and oak (with $75 \%$ ).

\section{Property Conditions.}

On the whole, property conditions developed not unsimilarly to those of Germany. There were freemen and serfs to start with, developing into barons, peasants, burghers; there were ban forests, royal domain, forests of the mark and private properties, rights of user or servitudes and all the methods and conditions that were developed in other parts of Europe, only perhaps differing in time and rate of progress of their development.

As a result of gradual changes in ownership conditions the present distribution of property resulted, in which the State ownership is comparatively small, namely, in Austria proper not more than $7 \%$ (with $1,565,000$ acres) of the $24,000,000$ acres of total forest (32.2\% of the land surface), while private ownership represents over 58\%. Of this $34 \%$ is in large landed estates, among which those of the princes of Liechtenstein and of Schwarzenberg with round 350,000 acres and 290,000 acres are the largest, and 25 others with from 50,000 to 230,000 acres may be named. The 
communal forest comprises $13 \%$, entailed forest $8 \%$, and the rest belongs to church and other institutions. By the middle of the 19th century at least $75 \%$ of the forest area was in large compact properties, a guarantee for the possibility of forest management; the industrial development of the last decade has, however, led to considerable exploitation.

2. First Attempts at Forest Control.

The oldest record of attempts at an orderly management in any part of the empire seems to date back to the 12th century when the city forest of Vienna had been placed under management, and during the 16th and 17th century this property appears to have been managed upon the basis of careful surveys and estimates. We also find a definite forest organization in the forests attached to the ducal salt mines in Styria by 1524, and the dams, canals and water works for floating timber developed by 1592 through Thomas Seeauer were the wonder of the times.

In 1524 also Archbishop Mathous Lang of Wellenburg issued a forest ordinance which was full of wise prescriptions, probably little heeded.

In the Alp territory, especially in Styria, the regal right to the mines combined with the "Forsthoheit" led early to the reservation by the dukes of whatever forest was not fenced or owned by special grant. In addition a superior right was asserted by them in some of the private forests to all the forest produce beyond the personal requirements of the owners; and what other private property existed was burdened by innumerable rights of user. The exercise of these rights, and the warfare 
against irksome restrictions led to widespread illegal exploitation and devastation, which as early as the 15th century had proceeded to such an extent that in Tyrol associations for protection against the torrents were already in existence. Yet in Tyrol, scantily populated, with one-third of its area unproductive and one-third forested, devastation continued until recent times in spite of the forest law of 1852, which instituted a forest police and forest administration of crown and communal forests. But in 1859 this organization was abolished before anything of value had been accomplished.

In Krain, which was unusually well wooded, forest reservations were made for the use of the mines and furnaces in 1510 and 1515, taking in all forest lands within a given radius. The balance was mostly divided among small owners, whose unrestricted, unconservative exploitation continued into the latter half of the 19th century.

In Styria, nearly one-half wooded and one-third unproductive, a regulated management was attempted as early as 1572 , and by subsequent forest ordinances of 1695,1721 and 1767 devastation was to be checked. But the resistance of the peasants to the regulations and the inefficiency of the forest service were such that no substantial improvement resulted.

In Galicia unusually extensive rights of user in the crown forests led to their devastation, and the attempts to regulate the exercise of these rights by ordinances in 1782 and 1802 were unsuccessful.

The forest area along the coast of the Adriatic in Istria and Dalmatia had furnished shiptimber even to the ancients. The Venetians becoming the owners of 
the country in the 15th century declared all forests national property, reserved for shiptimber, and placed them under management. They instituted a forest service, regulated pasturing and forbade clearing. The oak coppice was to be cut in 8 to 12 year rotation, with standards to be left for timber, etc. A reorganization of this service with division into districts is recorded in the 16th century, but the district officers, capitani ai boschi, being underpaid, carried on a nefarious trade on their own account and by 1775 the whole country was already ruined in spite of attempts at reform; the "Karst" problem remained unsolved; and when Austria secured Dalmatia in 1897 that country too was found in the same deplorable condition, the forest area, there in the hands of the peasants, having suffered by pasture and indiscriminate cutting.

It was the work of Maria Theresa to reform the administration of the various branches of government and wholesome legislation was also extended to the forest branch by her forest ordinance of 1754, which remained in force until 1852. It relieved the private owners, who held most of the forest area, from the restrictions hitherto imposed, except in the frontier forests. These, for strategic reasons, were to be managed according to special working plans prepared by the "patriotic economic society." The management of communal forests also was specially regulated. Otherwise the ordinance merely recommended in general terms orderly system and the stopping of abuses.

In $17 \% 1$ another forest ordinance proposed to extend the same policy of private unrestricted ownership to the Karst forests, with the idea that thereby better 
conditions would most likely be secured; but since here the property was not as in Bohemia in large estates but in small farmers' hands, the result was disastrous; as we shall see later, it merely led to increased devastation.

The same result followed the increase of private peasant ownership which came with the abolishment of serfdom in 1781. In 1782 an ordinance full of wise prescriptions against wasteful practice intended for the Northwest territory sought to check the improvident forest destruction.

A further wholesome influence on private forest management was exercised by the tax assessment reform in 1788, when not only a more reasonable assessment but for the first time a difference was made in taxation of managed as opposed to unmanaged woods and the epochmaking fertile idea of the normal forest was announced (see p. 108). At the same time the hunting privileges and other burdens, hampering forest properties, were abolished and measures for the extinguishment of the rights of user enacted.

\section{State Forest Administration.}

The State domain in the first half of the 19th century had been reduced by sales from nearly 10 million acres to 4.5 million acres, and to a little over 3 million acres in 1855. In that year about one-half of this property was handed over to the National Bank to secure the State's indebtedness of $\$ 30,000,000$, and between 1860 and 1870 large sales reduced the domain to its present size, when (in 1872) a new policy and the present organization was instituted. 
Before 1849 the forest properties which the Crown or State owned in the various territories were not managed as a unit or in any uniform manner, but a number of separate provincial or territorial forest administrations which were often connected with mining administrations had existed, and these under the influence of the educated foresters issuing from the newly established forest school had been much improved. Nevertheless the Cameralists, as in Germany, were at the head of affairs and kept the technical development back until after the revolution of 1848 when the accession of Franz Joseph I brought many reforms and changes in methods of administration.

The Ministry of Soilculture and Mining was created in that year and, as a branch of it, a forest department, separated from the department of the Chase, to the head of which was called a forester, Rudolf Feistmantel, who elaborated an organization. But before much had been accomplished the Ministry and its forest department were abolished (1853) and the forest domain again transferred to the Ministry of Finance.

Feistmantel returned in 1856 as Chief of the forest division in that Ministry, and his organization of the forest property of the State into forest districts under forest managers and into provincial "forest directions" was perfected.

Matters, however, did not thrive and, only when public attention and indignation had been aroused by a policy of selling State property, a change of attitude took place in 1872 which led to the present organization. This places the State forest administration in the Department of Agriculture, with an "Oberlandforstmeister" and two 
assistants as superior officers, and the rest of the organization is also very nearly the same as that in vogue in most German States, each province having a directive service of "Oberforstmeister" with "Forstmeister" as inspectors, and "Oberförster" with the assistance of "Forstwarte" as executive officers. In addition a special corps of "forest engineers" and "superior forest engineers" is provided for the elaboration of working plans. Lately (1904) a re-organization of the central office provided, besides the department of administation of State and Funds forests, a department of reboisement and correction of torrents, and a department of forest police charged with the promotion of forest culture, including the education of foresters and similar matters.

Most of the State property is located in the Alps and Carpathian mountains at an elevation above 2,000 feet, hence financial results do not make a good showing.

Since 1885 it has been the policy to add to the State forest area by purchase, and by 1898 over 350,000 acres had been added to it.

\section{Development of Forest Policy.}

Besides the State forest administration a very unique institution was organized to supervise the general forest protective policy of the empire. Originally the regular circuit or district governments had charge not only of the management of State forests but also of the forest police and the regulation of the management of communal forests, mostly without technical advisers, and the different provinces had developed this service very variably. While in some provinces no special effort was made to look after these interests, the laws remaining 
mainly dead letters, in others a better system prevailed, as for instance in Styria where in 1807 , five forest commissioners and 20 district foresters were employed, although this organization was of short duration. A loose administration of the forest laws was most general, and only when the severe floods of 1851 had forcibly called attention to this state of things was the necessity of change recognized. At first the reform had reference only to the Alp districts, which had suffered the most and in Tyrol an organization was created in 1856 which was to manage the State forests, supervise the management of corporation forests and exercise the forest police. This service underwent various changes. Not until the years 1871-74 was a similar service extended to other portions of the empire but at the end of that period the entire empire had been placed under the administration of the "forest protective service."

In 1888 this service consisted of 14 forest inspectors, 56 forest commissioners, 63 forest adjuncts and 80 assistants and forest guards; in addition 252 special appointees and officers of the State forest administration were doing duty in this service, so that altogether nearly 500 persons were then employed in carrying on the protective forest policy of the State.

The law declares the function of this technical service to be: "to assist the political government by technical advice and observation in supervising forest protection, and in the application of the forest laws."

In 1883 the functions of this organization were extended "to instruct and encourage forest owners in forest culture, and to manage forests designated to be 80 managed." The service has been so satisfactory that 
while at first much complaint against the enforcement of the regulations was heard, owners now ask constantly for its extension.

The details of the duties devolving upon this organization are found in a series of laws, applicable to different parts of the empire, which are based upon the recognition of protection forests, in which sanctioned working plans regulate the management. Forcible reforestation and employment of competent foresters in these are obligatory. Altogether about $60 \%$ of the Austrian forest area is managed under working plans.

As a result of a translation from the French of Demontzey's great work on the reboisement of mountains, by $\nabla$. Seckendorff in 1880 , and a subsequent report by the same author in 1883, a reboisement law, similar to that of the French was enacted in 1884, for the regulation of torrential streams under annual subventions of $\$ 100,000$ by the State. At the same time for the regulation of the lower rivers an appropriation of $\$ 1,350,000$ was made, of which $\$ 400,000$ was to be used for reforestation work.

This work as well as the reforestation of the Karst under the laws of $1881,1883,1885$, is carried on by the forest protective service.

On the whole the forest policy of Austria tends toward harmony with forest owners and liberation of private property. By reduction of railroad freights, which are under government management, by abolition of export duties, by reasonable tax assessments, etc., the wood export trade (now exceeding 20 million dollars) is favored; by the extinction of rights of user under liberal laws improvement in forest management is made possi- 
ble, the Emperor setting a good example in 1858 by renouncing his superior right to forest reservations in the Alp districts.

The best exemplification of the spirit of the Austrian forest policy and of the methods of forest organization and administration is to be found in the administration of the provinces of Bosnia and Herzegovina described in a volume just published by the veteran Austrian forester, Ludwig Dimitz.*

Here the Austrian government has in the short time of 25 years succeeded in bringing orderly conditions into the forest management. Until 1878 these countries were provinces of Turkey and were annexed to Austria as a result of the Russo-Turkish War. The Turks had already attempted a management of the forest lands, which were in their entirety claimed by the Sultan. Property conditions being entirely unclear when the Austrians assumed the administration, these questions had first to be settled by a survey. This survey resulted in showing a forest area of 6.3 million acres, $51 \%$ of the land area, of which probably all but about 1.5 million acres is private or communal property; half of the state property is fully stocked and it is estimated that about 100 million cubic feet is the annual increment.

\section{Progress of Forest Organization.}

Since 1873 working plans according to unified principles have been prepared for most of the State property so that by 1898 about $82 \%$ was under regulated management.

* Die forstlichen Verhältnisse and Einrichtungen Bosniens und der Herzegozina. Ludwig Disitz, Vienna, 1905, pp. 389. See Forestry Quarterly, Vol. III, p. 148. 
The method now largely employed is an area allotment checked by the normal forest formula, the so-called "Kameraltaxe."

The progress made in bringing forest areas under organized management varied greatly in the different provinces.

In northeastern Austria the first methods of regulated management consisted as in the neighboring territories of Germany, in a simple division into felling areas. The example of the neighbors was also followed later in the northwestern provinces, and in both regions this method was improved upon by allotment according to the propositions of Hartig and Cotta. In addition, since 1810, the method of the Austrian "Kameraltaxe" with the new and fertile idea of the "normal forest" began to be employed (see p. 108).

Especially in Bohemia by 1848 most of the large baronial properties had been put under a regular system of management according to Saxon and Prussian precedent. The influence of the former was especially strong and Saxon foresters were largely employed to regulate the management. Most prominent among these was Judeich, who became the Director of the forest school at Weisswasser, and afterwards of Tharand in Saxony. By 1890 over $83 \%$ of the total forest area of Bohemia capable of such management had been under rational working plans according to the most modern conception, and nearly the same proportion in the neighboring provinces of Moravia and Silesia.

In the Alps territory and the Danube provinces the regulation of forest management has not progressed with the same-rapidity, partly owing to the existence of the 
many hampering rights of user; only here and there are properties managed intensively. By 1890 only $23 \%$ were managed under rational working plans ( $40 \%$ state and $60 \%$ private and communal property), mostly regulated by a combined area and volume method.

In Styria in the forests attached to mines we find in 1795 quite a remarkable effort in the matter of working plans, with volume tables and sample area methods for determining the stock, but the fine plan was stowed away in a cupboard, and when in 1830 forest counselor Wunderbaldinger proposed to apply such a working plan he had to wait seven years before permission for a trial was granted. He continued the organization of these forests until 1848, using Hundeshagen's "use per cent." in the selection forest, and volume allotment for the woods managed under clearing system.

In lower Austria the Vienna state forest of 70,000 acres had for a long time received attention; the first thorough forest survey and yield calculation being made in 1718-20, revised in 1782-86 and regulated for the shelterwood system in 1820. Within the last 50 years the method has been changed again and again, until in 1832 the present Austrian method based on normal stock principles was applied. Since in this province 50\% of the forest area is peasant property and communal forest, which are usually managed without systematic plans, the $33 \%$ under working plans represents more than half of the area capable of such management.

In upper Austria, where the salt works are situated, the attempts at regulated management in connection with these date back to the middle of the 16th century, and after various changes these forest areas were by 1888 
placed under working plans of modern style. Over $50 \%$ of the forest area of this province is so regulated. One of the most modern working plans based upon Pressler's soil rent theory and a most intensive silviculture, is that of the Baron Mayr-Melnhof on his estate Kogl.

These details are merely brought forward to illustrate the great variation both in the progress of development and in the present conditions in different parts of the empire, similar differences being found in other portions. Suffice it to say that in round numbers about fifteen hundred thousand acres are managed under more or less intensive working plans, and of the balance seven million acres are farmers' woodlots on which only silvicultural treatment is necessary.

\section{Development of Silviculture.}

$\checkmark$ The necessity for conservative forest use and reforestation did not arise as early in Austria as it did in Germany. Not until the middle of the 19th century did this necessity become apparent in most of the provinces, when German experiences in silviculture could be n readily utilized.

In Bohemia the clearing system with artificial planting mostly by seed had been introduced at the beginning of the century for the conifer forests, planting being generally only resorted to in filling out fail places with wildlings, while in the broad-leaved forest the selection system and to some extent the shelterwood method, were largely followed. The strip system was also much employed, and as the felling areas were often made too large, undue increase of undesirable softwoods resulted. During the last 50 years silvicultural theory 
and practice developed very much on the same lines as in Germany, more intensively in the densely populated and more accessible regions and less so in the more distant and thinly settled mountain districts.

The most noted work of reforestation which has occupied Austrian foresters for the last forty years or more is that of the "Karst," a name applied to the waste lands in the mountain and hill country of Istria, Trieste, Dalmatia, Montenegro and adjacent territory skirting the Adriatic Sea. It is a dry limestone country of some 600,000 acres in extent, stony and rough and overdrained. Originally well forested with conifers and hardwoods it had furnished for ages ship timber and other wood supplies to the Venetians. Through reckless cutting, burning and pasturing by the small farmers it had become almost entirely denuded, natural reforestation being prevented by these practices combined with the dryness of the soil, intensified by the deforestation.

For centuries countless laws were passed to stop the progress of devastation, but without effect.

The first attempt at planting was made by Trieste in 1842 and found some imitators, but with meager result.

In 1865 the Austrian government, acting upon representations of the Forestry Association, undertook to encourage and assist private landowners in reforesting their Karst lands by remitting tares on reforested lands for a period of years, by technical adrice and by assistance with plant material and money.

By this move so much land was withdrawn from pasture and taxation that opposition was aroused among the cattle owners, which led to additional legislation during 
the years 1882 to $188 \%$ and finally to the creation of a commission charged to select the lands which in the interest of the country required reforestation and to enforce this within a given time, the State expropriating the lands of objecting owners. At the same time the Commission brought about the division of pasture lands which were held in communal ownership.

By $189 \%$, of the 75,000 acres selected by the Commission as of immediate interest 15,000 acres had been planted, mostly with Austrian pine, at an average cost of $\$ 8$ to $\$ 16$ per acre, the cost including stone enclosures for the plantations, to protect them against cattle and fire, and the repairs which sometimes equalled the original expense. In addition some 50,000 acres of natural growth were merely by protection brought into productive condition.

While this activity refers to the northern portion of the coast region, the Karst of Dalmatia farther south, being oak country, was mainly recuperated by protective measures. In 1873 the pasturing of goats was forbidden on areas of over one million acres in extent, which were found capable of reforestation. In $18 \% 6$ the division of communal holdings was ordered and portions designated for forest use, some to be planted. As a result of these measures nearly 400,000 acres have been recuperated.

\section{Education and Literature.}

The first forest schools in Austria were established through private effort, namely one in 1800 in Bohemia by Prince Schwarzenberg, and another one in Moravia by Prince Liechtenstein, these two being the largest for- 
est owners in Austria. In 1805 another private forest school was opened in Bohemia, and at the same time the state institute near Vienna came into existence. This was in 1813 transferred to Mariabrunn, and, after various changes in the character of the teaching, was, in $186 \%$, raised to the dignity of an academy with a three years' course. In 1875 it was transferred to the Hochschule für Bodenkultur at Vienna, an agricultural school which had been instituted in 1872 intended to give the higher scientific education in both forestry and agriculture by a three years course. During the years from 1875-1904, over 2,600 students in forestry alone had attended this excellent school at which 71 professors and instructors are employed.

For the lower grades of foresters schools were from time to time opened in addition to the private ones first mentioned. At the present time there are in existence three so-called "middle schools," Eulenberg (founded in 1852), Weisswasser (1855) and Lemberg (1872) at which the course is two years, and one at Bruck (1900), where the course is three years.

For the education of guards three Forstwart schools were instituted in 1881 and 1883, one each for Tirol, Styria and Galicia, where in an eleven months' course 15 forest guards at each receive instruction. In addition there are five schools of silviculture where the course is one year. Besides these schools courses in forestry of shorter duration are given at three other institutions.

Beside these schools the promotion of forestry science is, as in Germany, secured by forest experiment stations which came into existence as a result of the earlier deliberations of the German foresters; the pro- 
position to establish such stations being submitted in 1868, but their establishment was delayed until 1875 , when such a station was instituted at Vienna in connection with the schools there. The results of the investigations are published from year to year and have enriched the forestry literature in the German language with many important contributions.

A very active association life exists in Austria, largely due to the influence of the many large private forest owners. Curiously enough the first attempt at forming a society of foresters in Bohemia was suppressed by the authorities, probably for fear of revolutionary tendencies, and the effort simply resulted in a literary or reading association to obviate the need of private purchase of books. Not until 1848, the very year of the revolution, did the Bohemian forestry association become a fact, and under the leadership of the large forest owners among the nobility it has become the strongest in Austria, issuing a bi-monthly association journal from the beginning. Another strong local association which dates its beginning as a society for agriculture, back to 17\%0, is the Moravian-Silesian Forestry Association which segregated from the mother society in 1850 first as a section, and, having attained a membership of 1,000 , by 1858 , constituted itself a separate association in 1886 . Besides these, many smaller ones exist in Austria. In 1852 a general Austrian forestry association was founded which in 1854 began the publication of a quarterly and held sessions in various parts of the empire; but by and by the interest seemed to flag, the attendance at the meetings became smaller and smaller, and finally the associa- 
tion was abandoned after a rival, the Austrian Forestry Congress, had been organized in 18\%4, which later became the Oesterreichische Reichs-Forstverein.

In Galicia and in Bukowina the foresters meet as a section of the Society for Soil Culture. The same method of forming forestry sections of the agricultural societies is followed in others parts of the empire and at least a dozen or more other local foresters' associations might be mentioned in which owners of forest properties are as fully represented as professional foresters, and their activity is not only to be found in literary labors, but also in practical work. In addition to the meetings of these local societies representative congresses have met annually at Vienna since 1876 and have become powerful agents for improving legislation and practice.

Although, as was natural, owing to the difference in conditions the forestry literature in Austria began much later than that of Germany a very active progress is noticeable since the middle of the century, and the Austrians are vying successfully with the Germans in this direction. The names of Fioceli, Pokorny, Böhm, Wiesner, Molish, Willkomm, Hempel and Kenner in the direction of forest botany, Wessely, von Lorenz-Liburnau, Schindler, Feistmantel, Dimitz, Dombrowski (encyclopedia 1886), Exner (wood technology) Guttenberg (forest mensuration and regulation), Ney (silviculture), von Seckendorff, Schiffel (forest mensuration), and many others are familiar to all German readers. In addition a very considerable literature in the Bohemian language is in existence, some in the Italian by Austrian authors, and some in the Slavonian. 
The magazine literature began with publications by various forestry associations which became active after 1848. At the present time weekly, monthly, bi-monthly, quarterly, yearly and irregular publications to the number of not less than 14 in German, in addition to several in Bohemian, may be counted, among which the monthly Centralblatt für das Gesammte Forstwesen, in existence since 1875 , and the only weekly, Oesterreichische Forstzeitung since 1883, are perhaps the most widely known.

\section{HUNGARY.}

Although naturally influenced by Austrian precedent, forestry matters in Hungary like all matters of administration are independent of Austria, the connection being only in the identity of the emperor.

The forests which had been largely the property of the kings of the Arpad dynasty had been by them turned over in donations to the churches, cloisters and to colonists, so that by 1526 when the Hapsburgs succeeded, only a small portion remained, and this became State property.

In the forests which were necessary for the working of the royal mines and furnaces an attempt was early made to secure systematic treatment under an ordinance (1565) which gave instructions as to the order of fellings, the reservation of seed trees, etc. But on the whole the government did not make much effort at regulating forest use until past the middle of the 18th century, and then largely owing to military considerations urged by General von Engelshoffen commanding on the frontier 
against the Turks. The planting of forests for defense was ordered (1743) by Maria Theresa, but this order was probably never executed.

About this time, however, movements of reform in various directions are noticeable. About 1750 complete working plans were made for the Kremnitz forest and in 1763 for the Schemnitz forest. The forest ordinances of $1 \% 70$ and 1781 and the law of 1791 attempted to regulate the use of communal forests and ordered the reservation of devastated forest areas. Other legislation followed in 1807 designed to arrest the further extension of shifting sands.

Although since 1809 forest inspectors had been employed to look after the execution of the forest laws, mismanagement and forest destruction by promiscuous cutting, pasture and fire remained the rule and with the advent of the railroads in 1850 increased apace.

Political troubles prevented any attempts at improvement until in 1867 comparative peace and the new régime had arrived, and finally in $18 \% 9$ it became possible to pass a reform law, which is the basis of present conditions.

At present, of the 23 million acres of forest the State owns $16 \%$, corporations somewhat over $20 \%$, churches, cloisters and other institutes $7.5 \%$ and the balance is owned privately. Of the private properties the majority consists of large holdings and about ten per cent are entailed, a hopeful condition for conservative management. Yet with an export of 10 to 12 million dollars or inore, exploitation would appear still to be general, and devastated areas abound. It is claimed that half the area is under working plans and that the 1000 million 
cubic feet of annual cut do not approach the annual increment. The State forests yield now in the neighborhood of $\$ 600,000$ net.

The State interests were in 1879 placed under the administration of the Department of Agriculture with a technical forester at the head (Oberlandforstmeister) assisted by four section chiefs, one in charge of the State forest administration, one for the administration of corporation forests, one for the elaboration of working plans and one, with the assistance of 20 forest inspectors having supervision of the execution of all forest laws. Otherwise the general features of German administrative measures prevail, except that for purposes of executing the protective forest laws, committees composed of three members chosen from the county officials co-operate with the government service.

The law of $18 \% 9$ provides government supervision of the management of corporation and of protection forests ( 1 million acres in the mountains and on sanddunes), and prescribes that land unfit for farming, i. e., absolute forest soil (three-quarters of all forest land), no matter by whom owned, is to be reforested within six years after having been stripped. Mountain forests, which are classed as protection forests, as well as entailed properties, must be managed according to working plans approved by the forest department. Violations of this law are liable to be punished by a fine for each acre, imposed annually as long as the offense continues. Twothirds of the whole forest area is thus more or less under State supervision, and working plans for over 12 million acres have been or are to be prepared by the government. An area allotment method with a normal forest formula 
as a check has been mostly employed in this work, which is by no means as yet completed.

To promote forest planting several nurseries have been established by the government, from which around 10 million plants are annually distributed free of charge and subrentions for reforestation of wastes are also granted annually. It is interesting to note in this connection that more than $1 \% 0,000$ acres have been planted to Black Locust, which is managed as coppice for vineyard stakes.

In 1884 a special fund for the purchase of forest land by the State was instituted by turning all moneys received from eventual sales of forest land into that fund. Another fund for forest improvement is accumulated by placing four-fifths of all penalties collected for forest trespasses into a separate account for that purpose. These funds have not accumulated very fast, the forest improvement fund in 1896 being only about $\$ 120,000$.

Similar to the Landes in France there exist in various parts of Hungary extensive sand wastes and shifting sands, partly caused by deforestation. Ever since 1788 legislation has attempted to secure a re-habilitation of these waste areas, which cover in all some 600 square miles. In 1817 a first systematic beginning was made in the Banat on the "Alföld" of the Magyars under the forest director Bachofen, similar to Bremontier's undertaking in France. By 1812 the total plantations amounted to about 12,000 acres and by 1869 some 20,000 acres had been reforested and parts of the plantations had begun to yield profits. But even to-day there are still large areas in a desert condition.

A classic volume in German by Joseph Wessely, Hun- 
garian forest director, Der europaeische Flugsand und seine Kultur describes in detail the principles and methods of reclamation of shifting sands.

Most of the Hungarian forestry literature being written in the Magyar language, is inaccessible to the rest of the world.

Efforts by private endeavor to promote forestry education date back as early as 1796, when Forest Inspector Vizner opened an elementary forest school and wrote a forestry catechism.

This effort was followed in 1806 by introducing the subject in the agricultural school at Keszthely, and in 1808 in the school of mines in Schemnitz (Selmecz banya), a German forester Wilkins filling the chair, while a special forest school was established at Hermannstadt in $181 \%$.

The forestry courses at Schemnitz were enlarged and the school re-organized in 1846 and again in 1872; one of the changes being the use of the Hungarian language in its instruction, which had originally been in German.

In 1904 the course which was 3 years and only optionally 4 (one year for engineering education) was made 4 years for all, and is obligatory for all higher grade State officials.

In Croatia-Slavonia, which is in many respects separately administered, an agricultural and forestry school exists at Kreutz (Körös) with a three-year course.

For the lower service four schools of two-year courses have been established by the government, the instruction being given by practitioners, and some of the students receiving free tuition. 
A forest experiment station was established in 1898; it issues a quarterly magazine in which its results are recorded.

A Hungarian forestry association was formed in 1866 ; it issues a monthly journal, distributes pamphlets, gives prizes for literary effort, etc., and is with over 2000 members an active agent in the work of reform. A separate forestry association, which also publishes a monthly in the Slavish language, exists in Croatia. 


\section{SWITZERLAND.}

The interest which we have in the development of forestry in this small territory, of somewhat less than 16,000 square miles with over three million people, lies in the fact that it is a republic, or rather an aggregation of republics, the oldest in existence, and that, occupying an Alpine mountain country, it has developed a unique co-operative policy of forest protection. Being largely German by origin and sentiment, German influence on the development of forestry methods, outside these administrative measures, has here been as strong as in Austria.

Switzerland did not exist as a power in name until the 17 th century, and as a unit not until the reconstruction of 1815, and in its present settled condition and constitution not until 1848, although the nucleus of its

A very good brief statement of present conditions of forestry in Switzerland with some historical references may be found in Handwörterbuch der Schweiserischen Volkswirthschaft, Berlin 1903 with two chapters by DR. J. CoAz and Prof. C. Bourgeots.

F. FANKHAUSER, Geschichte des bernischen Forstwesens bis in die newere Zeit, Bern 1893, which gives insight into the developments in one of the cantons, beginning in 1304.

LANDOLT, Ueber die Geschichte der Waldungen und des Forstwesens, Zurich 1858. 1896.

L'évolution forestière dans le canton de Nenchâtel, Histoire-Statistigue

BURRI, Die Kulturgeschichtliche Entwicklung und wirthschaftiche Bedeutung des schweizerischen Waldbestands, Luzern 1898.

MEISTER, Die Stadtwaldungen von Zürich 2d ed. 1908 exhibits on 225 pages in great detail the history and methods of management of this remarkable city forest of only about 8,000 acres.

Report to the British Foreign Office on Swiss Forest Laws, by CONWAY THORNTON 1888 gives a very satisfactory exposé of the earlier legislation. 
political existence dates back at least 600 years, when in 1291 the people of the three forest cantons, Schwyz, Uri and Unterwalden formed their first league to resist encroachments on their rights by the church and by the feudal barons.

The country became settled similarly to Germany by Germans and especially Burgundians, a free people; but when the control of the Obermärker over the free communities began to ripen into feudal superiority it found resistance in the forest cantons, and these formed a league to fight the duke of Hapsburg, who partly as feudal lord, partly as Reichsvogt, the emperor's representative, claimed obnoxious rights. Through admission of neighboring lands and cities to the league, the number of confederates by the middle of the 14th century had grown to eight, and when by the battles of Sempach (1386) and Næfels (1388), the Austrian Hapsburg supremacy had been permanently wiped out, the number of allies grew and, by conquest and annexation and otherwise, their territory attained nearly the present size by the middle of the 15 th century; the war against feudalism being the cause for this growth.

These various small republics, however, always formed a part of and owed allegiance to the German Empire, although they resisted the arms of the Emperor as Archduke of Austria, until with the peace of 1499 this connection became entirely nominal. The final separation from the German empire and acknowledgment of independence was not pronounced until the peace of Westphalia in 1648.

The league was only a very loose confederation without any central power, although a diet, to which each 
canton sent a delegate, had deliberative functions. Almost immediately after the alliance was formed it became fatally divided, especially when religious differences arose, and throughout the 16th and first half of the 17 th century continuous warfare existed between the different allies.

It must not, however, be understood that the peasants in the different cantons were entirely free from the ancient tyrannies. With the exception of the three forest cantons, which were truly democratic republics, the majority of the Swiss peasants, free in the eyes of the outside world, were mere serfs until the beginning of the 18th century, and secured their freedom only after many revolts.

After nearly 500 years of this loose federation, it was reserved to Napoleon to proclaim the Helvetian Republic one and indivisible in 1798, after a short struggle of 74 days. This constitution fell with the fall of $\mathrm{Na-}$ poleon, and gave place in 1815 to a re-organized federation, in which the former sovereignty of each canton was re-established, the inviolability of the territory being guaranteed by the European powers. Finally in 1848, the seventh and last phase of reconstruction brought into existence the "Bund," the Confederation of Switzerland, very much after the pattern of the United States, the constitution then adopted being once more revised in 1874.

The country is divided into 19 entire and 6 half states or cantons, which are a unit towards foreign powers, but have as much independence among themselves as our States, each self-governing. A parliament (Bundesversammlung) of two chambers, the Nationalrath of 145 
members corresponding to the House of Representatives, the Standesrath with 44 members, equivalent to the Senate, represent the interests of the whole federation. The administration of the cantons lies in the hands of the "great" and "small" councils with an executive ministry of three members chosen for two years by the former council. The administration of the Bund is in the hands of the Bundesrath of 7 members elected by the parliament, which also elects one of the members as president for one year. The Referendum, which, if 30,000 voters demand it within 3 months, requires reference of any law to the direct vote of the people is used as a check on legislation.

Although the larger part of the population of 3 million people is German, parts of Switzerland are French and other parts Italian.

From this brief statement of the political development of the country it will appear that the development of forestry must also have varied.

Topographic and soil conditions necessarily had their influence on this development also. In the plains, the platean, and the hill country the distinction of forest and field as it now exists had been in general attained in the 15th century, while in the mountain country forest destruction began only in the 18th century and continued till the middle of the 19th century, stimulated by the development of the metal industry and the improvement in means of communication. The clearings made here were turned into pasture and, being overpastured, became waste lands. Thus owing to topographic and soil conditions a very uneven distribution of forest has resulted and we find a variation in forest area 
from $9 \%$ (Basel and Genf) to over 39\% (in the Jura) of the total land area of the different cantons, the average being $20 \%$, leaving out of consideration the area above timber limit (5,000 to \%,500 feet), and the waters and rocks below. This is less than in Germany and Austria, more than in France. But if unproductive soil, which represents over $28 \%$, is excluded, the percentage of forest area on productive soil would about equal Germany.

Property rights developed at first similarly to those developed on German soil, except that, as we have seen, feudal conditions were not allowed to gain foothold to the same extent, and liberty from serfdom was secured earlier. At present, ownership is still largely communal : of the 2 million acres of forest nearly $67 \%$ are so owned, making this property of highest forest political importance; private owners hold only $28.6 \%$ and the cantonal forests represent but $4.5 \%$, the Bund as such owning none. It is also to be noted that communal property is constantly increasing by purchases from private holdings.

No doubt in some parts the first beginnings of care for forest property and forest use date back even to Roman times. Charlemagne had his forest officials here as elsewhere, and the number of ban forests seems to have been especially great, some 400 "bannbriefe," documents establishing them, having been collected at Bern. The first forest ordinance regulating the use of a special forest area in Bern dates from 1304. But the first working plan seems to have been made for the city for- 
est of Zürich, the so-called Sihlwald in 1680-169\%, and to this day this corporation property, with its intensive and most profitable management, is the pride of all Switzerland. The Bernese cantonal forests were first surveyed and placed under management from 1725 to 1 i39 and fully regulated by 1765 .

An excellent forest code for Bâle was drawn up in 1755 by Bishop Joseph William; and in 1 r60 through the propaganda of the two scientific societies of Zurich and Bern, the teaching of forestry was begun, and forest organization in the two cantons secured in 1773 and 1786 . The canton of Soleure (Solothurn) was the first to start a regular system of instruction, two citizens from each woodland district being given the opportunity to qualify themselves as foresters.

Each canton had, of course, its own laws protecting forest property against theft and fire; in the latter respect especially great care was exercised and burning of brush could only be done by permit and under a force of watchers.

The example of Zurich and Bern in organizing the management of their forest areas was followed more or less by other cantons, but a real serious movement is not discernible until the beginning of the 18th century when with the impetus of modern life and trade the value of forest property increased, and most cantons issued regulative forest laws.

Forest ordinances had from time to time attempted to prevent the decrease of forest area by forbidding clearings, regulating pasture, and forbidding wood export to other villages or cantons, a local timber famine being dreaded. But only when a severe flood in 1830 
had accentuated the protective value of forest cover were the forest ordinances more strenuously enforced, and a general movement for better management began. This was partly signalized by sending young men to the forest schools of Germany.

Largely through the influence of a lively propaganda carried on by such men as Landolt and Coaz, backed by the Swiss forestry association, founded in 1848, and through the increase of torrential floods, especially in 1834 and 1868, was it made clear that a central power would have to be clothed with authority to regulate the use of the alpine forest at least.

In $185 \%$ the Bund ordered an investigation of the mountain forests in all parts; this was made by Landolt. At the same time an annual vote of $\$ 2,000$ was made to the Forestry association for reforestation and engineering works in the Alps. This grant' was changed in 1871 by voting an annual credit of $\$ 20,000$ to be expended by the Bundesrath for similar purposes. The floods of 1868 brought such distress in certain cantons that contributions from all other parts were required to assist the flood sufferers; and of the collections $\$ 200$,000 were appropriated for reforestation. Finally in 1874 it was determined to create a central bureau of forest inspection for the whole Bund in the Department of the Interior, and a law was passed in 1876 declaring the superior right of oversight by the Federation over the water and forest police in the high Alps, proposing to aid in the engineering and reboisement work necessary to correct the torrents, and to take measures for the preservation of these works and forests.

It will be noted that the federal surveillance was to 
extend only to the High Alps above a certair limiting line. This limitation was removed in 1898 by resolution of the Council, and finally by 1902 a revised law was passed establishing fully the present Federal forest policy.

This law places the surveillance of all forest police in all forests of Switzerland in the Bund, the private forests as well as the public, i. e., State and communal or corporation forests. But as there are distinctive differences in the manner of this surveillance a differentiation of ownership conditions and forest conditions is to be made by the cantons within two years.

The forests are to be divided into protection and nonprotection forests, the former being such as are located at headwaters or furnish protection against snowslides, landslides and rockfalls, floods, and climatic damage. Most of this segregation had already been made and mapped in consequence of the law of $\mathbf{1 8 7 6}$.

All public forests are to be surveyed and their corners permanently marked by the cantons according to instructions by the Bund, the latter furnishing the needed triangulation survey, and inspecting and revising any older surveys free of charge.

The surveyed public forests are to be fully regulated according to a sustained yield management under working plans made according to instructions by the Cantons, to be sanctioned by the Bundesrath. For the unsurveyed forest areas at least a provisional felling budget is to be determined, as nearly as possible representing the sustained yield. In protection forests the working plans must conform to the objects of these forests, and clearings in these are as a rule forbidden. The fellings are 
to be made under direct supervision of foresters and after being cut the wood must be measured. Sale on the stump is forbidden, otherwise no interference in the management is intended.

Up to 1902 , under the law of $18 \% 6$, working plans for 540,000 acres had been made.

For other than protection forests the law provides a number of restrictions, such as the following: Pasture woods may not be decreased in area except by permission of the cantons. Communal forests are not to be subdivided without consent of the cantonal government, except where two or more communities have joint ownership, nor are they to be sold except with such permission. Rights of user in public forests, especially in protection forests, may be forcibly extinguished by the cantonal government, but under appeal to the Bundesrath. Money equivalents are to be the rule, territorial equivalents only to be given by special permission. By 1902 over $\$ 300,000$ had already been 'spent to extinguish 2,842 different rights of user. The establishment of means of transportation, roads, etc., is encouraged by subventions from the Bund and otherwise.

Private forests as far as they fall under the classification of protection forests are subject to the same supervision and rules as the public forests as regards their survey, the prohibition of clearings except by permission of the Federal Government, and of diminishing pasture woods, the extinguishment of rights of user, the prevention of damaging use and assistance in establishing means of transportation. The cantonal government is obliged to insure the execution of these laws.

In additon, while the law encourages co-operative for- 
est management of small holdings as larger units, the Bund paying for the cost of effecting such co-operation, it empowers the canton or the Bund to enforce such cooperative management of protection forest areas in specially endangered localities as at the headwaters of torrential streams. Otherwise in the non-protective private forests only the prohibition of clearing except by permission of the cantonal government, the obligation of reforesting felling areas within three years and of maintaining existing pasture woods is ordered. Whereever on private properties conversion of forest into farm or pasture is permitted (after report of the forest administration of Canton or Bund) an equivalent reforestation of other parts may be ordered. Wherever by the reforestation of bare ground protective forest areas can be created, this may be ordered, the Federal or the Cantonal government contributing towards such work, or else, if the owner prefers, he may insist upon having his ground expropriated by the Canton or other public corporation; the federal government assisting in either case to the extent of 30 to $50 \%$ of the cost, and in establishing new protection forests to the extent of 50 to $80 \%$.

Before 1902 under the law of $18 \% 6$ some 16,000 acres had been reforested and put in order at an expense of over one million dollars, the federal government contributing just about fifty per cent.

Besides the various restrictions with provisions of penalties for disobedience (from $\$ 1$ to $\$ 100$ for each transgression) and enforced execution by cantonal government, there are a number of directions in which the Federal Government makes contributions for the pur- 
pose of encouraging conservative management. For the salaries of the cantonal higher forest officials 20 to 35 per cent. are contributed, for the higher corporation and co-operative association officials 5 to 25 per cent., for the lower forest service 5 to 20 per cent. The Federation participates to the extent of one-third in the accident insurance of forest officers; a minimum salary of the officials and also their proper education being made conditions. To secure the latter the Federation pays for teachers and demonstration material under prescribed conditions.

In 1901 the federal contributions amounted to $\$ 100$,000 in all. In 1903 the total appropriation was $\$ 126,-$ 000 , namely, $\$ 9,000$ for the Inspector-General's office; $\$ 26,000$ towards salaries of cantonal foresters; $\$ 80,000$ towards reboisement; $\$ 8,000$ towards survey. The cantonal governments contributed about the same amount outside of the cost of their forest administrations. It is estimated that the budget will have to be increased by $\$ 50,000$ annually for some time to come.

The organization which is to carry out this forest policy is still the one which originated with the law of $18 \% 6$, somewhat modified by the law of 1892 , namely, a forestry division in the Department of the Interior with one Superior Forest Inspector and three assistants.

The Cantons have their own administrations, mostly under one forester of higher grade (called variously Oberförster, Forstinspektor, Forstmeister, Oberforstmeister. Bern has three co-ordinate Forstinspektor). The Cantons are or are to be districted into forest circles (Forstkreise) the subdivision to be approved by the 
Bundesrath, and some are further subdivided into ranges (Unterförsterei). These forest districts, from 7.500 to 45,000 acres each, are to be managed by properly educated and paid foresters elected by the people. The eligibility depends upon an examination, the theoretical part of which is conducted by the forest school, the practical part after a year's practical work is conducted by a commission of foresters, after completion of which the candidate becomes eligible; the election being for three years, and re-election being usual, unless there are good reasons against it.

In 1903 there were employed as administrators or managers 119 State foresters and 33 Communal foresters, besides 11 Federal forest officials. The State foresters are allowed to manage neighboring communal properties.

For the education of the higher forest officials the Federal government instituted a two year course at the Polytechnicum at Zurich which was founded in 1855 , the course being in 1884 increased to three years. Three professors of forestry besides the faculty of the institution in fundamental and accessory branches are active here, the number of students in 1902 being thirty-five.

For the education of the lower grade foresters the Cantons themselves are responsible, the Bund only contributing by paying for teachers and demonstration material (about $\$ 1,250$ ) to carry on cantonal or intercantonal forestry courses. The courses usually last two months, in succession or divided in spring and fall; they are mainly practical and require candidates to be not less than 18 years of age and to possess a primary 
school education. Their number must be at least 15 and not more than 25. There have also been instituted specially conducted excursions and progressive underforesters' courses, as well as additional scientific courses which the Bund subsidizes.

In connection with the Zurich school, forestry science and art are further advanced by a well-endowed central Forest Experiment Station, with several substations and an annual credit of $\$ 10,000$.

The greatest credit for the advancement of forestry and forest legislation is due to the Swiss Forestry Association (347 members in 1902), which was founded in 1843, meeting annually in various places, managed by a Committee of five elected for 3 years. This Association is subsidized by the Bund for its educational work. Schweizerische Zeitschrift für das Forstwesen (begun 1850) is its organ with Dr. Fankhauser as editor.

In 1898 an association of underforesters with a special organ, Der Forstwirth, came into existence (526 members in 1902), and several cantonal foresters' associations are also active.

In the literature. which is largely in German, with some French and Italian volumes, notable works have appeared and real advances in forestry science especially with reference to management of mountain forests are due to Swiss writers.

In 1767 the Société d'Economie de Zurich published a foresters' manual, and during the first quarter of the nineteenth century $Z$ schokke and Kasthofer developed silviculture in the Alps. Landolt in 1860 published the 
results of his investigations (under the order of the Bund of 185\%) of the forest conditions of the Alps and contributed other volumes along similar lines.

He was succeeded by the now venerable Dr. J. Coaz as Inspector-General of the Bund, who also contributed to the science of mountain reboisement and in other directions. The work on the management of the City forest of Zurich by its long-time manager Meister is classic. Under the active direction of Anton Bühler for many years (now Dr. Engler), Mittheilungen der eidgenössischen Centralanstalt für das forstliche $\nabla$ ersuchswesen, have become since 1891 important contributions to forestry science. In the direction of wood technology the name of $L$. Tetmajer, who is conducting timber tests should be mentioned.

The timber forest is the most general form of silvicultural management. Selection forest with 150 to 200 year rotations is practised in the Alps and in the smaller private forest areas. Shelterwood system in compartments is in use in other parts (with a rotation of 60 to 80 years in the deciduous and 80 to 120 years in conifer forest), supplanting largely the clearing and planting system which had found favor during the middle of last century.

In corporation forests large areas are still under coppice with standards, but will probably soon be converted into timber forest, a policy favored by cantonal instructions. Pure coppice is only rarely met, usually confined to the overflow lands and small private holdings. In some of the public forests in the French territory it is practised with a "double rotation" (furetage) according to French pattern. 
Artificial means to secure complete stands in natural regenerations is favored by the cantonal regulations, but thinning operations are still mostly neglected, except where local market for inferior material makes them advisable which is mostly in the plains country, where the annual yield from thinnings may represent $30 \%$ of the total harvest yield.

Conversion from coppice and coppice with standards into timber forest and change from clearing systems to natural regeneration (proper for mountain forest) and from pure to mixed forest have become general provisions of the working plans.

The average cut in the State forests during 4 years prior to 1893 was over 64 cub. ft. p. acre and $42 \mathrm{cub}$. ft. for the corporation forests, an average for all the public forests of round 45 cub. ft., not a very good showing as yet. So far the collection of material for yield tables and for a statement of increment and stock on hand in the country at large are still insufficient, although in 1882 Prof. Landolt estimated the annual product at little less than 500 million cubic feet or 50 cubic feet per acre.

Only for the intensively managed city forests of Zurich and the cantonal forests of Bern are more accurate data available. In the latter the State forests yield 50 cubic feet in the plateau country, 73 cubic feet in the middle country and 76 cubic feet in the Jura, while the communal forests yield 15, 66 and 56 cubic feet respectively. Prices for wood are higher in the low country than the average in Germany and have been steadily rising for the last 40 years, especially for coniferous saw material which at present brings stumpage prices of 12 to 15 cents. 
Owing to these high prices the gross yield of some Swiss forests is the largest known in Europe, the city forest of Zurich exhibiting yields of $\$ 12.00$ and the city forest of Aarau as much as $\$ 14$ per acre on the average, although in the Alps forests the gross yield sinks to $\$ 3$ and $\$ 4$. The more intensively managed city forests mentioned spend on their management $\$ 6$ and even $\$ 7$ per acre, while most of the State forests keep their expenditures within $\$ 2.50$ to $\$ 3.50$, and in some places down to $\$ 1.50$ per acre. The net yields vary therefore for the State and communal forests of the plateau country between $\$ 3$ and $\$ 6.50$ for some of the city forests from $\$ 6.50$ to $\$ 8$ and $\$ 9$.

Switzerland has long ago ceased to produce its wood requirements and imports from 6 to 8 million dollars annually of wood and wood manufactures. 


\section{FRANCE.}

Germany's neighbor to the West developed forest policies and practices which are quite different in some respects, although the early history of forestry in France was largely analogous to that of Germany. Indeed, until 911 , the two countries being undivided, the same usages existed more or less in both, except that in the Gallic country Roman influence left a stronger imprint, Gallia having been long under the dominion of Rome.

No complete monographic history of forestry in France is in existence, and only incomplete notes scattered through various volumes were at the disposal of the writer.

L. F. A. Mnury, Les forets de la Gaule et de Tancienne France, 1867, 501 pp. is mainly descriptive, but full of interesting historic data and detail up to the revolutionary period.

The work which contains the largest amount of historic information is G. HuFFel, Economie Forestière, vol. I, 1904, 419 pp., which has been largely followed in the account here given. Historic data regarding the development of the science in France are promised in the second volume, the first touching mainly on property changes, policies and administration.

Julas Clavf, Etudes sur l'economie forestiler, 1862, 377 pp, 120, while mainly a propagandist essay, rehearses to some extent the history of forest practice, policies, etc, and gives a good insight into conditions at that time.

Die forstlichen Verhaltnisse Frankreichs, by Dr. A. v. SeckendorfF, 1879, pp. 228 , furnishes a few bistorical notes.

Three English publications by John Croumbir Brown, Pine Plantations in France, Reboisement in France, 1876 : French Forest Ordinance of 1600,1882 , are profuse and not entirely accurate, but give hints of historic development.

Сн. Guyot, L'enseignment forestier en France, 1898, 398 pp., gives an insight into the development of forestry education and a complete history of the school at Nancy, and throws much light on other developments.

Code de la législation forestière, par PUTON, contains all the legislation having reference to forests.

An article on L'idée forestiere dans l'hestoire, by L. F. Trssinr, in Revue des eaux et forêts, 1905, Jan., Feb., gives on 26 pages an interesting brief survey of the history of forest policy in France.

Forestry in France, by F. BALLr, in the Indian Forester, 1886, 61 pp., describes well conditions at that time. 


\section{Development of Forest Property.}

In ancient Gaul the Romans found the forest as communal property, except the holy groves. After the conquest all the unseated lands, especially the extensive mountain forests, were declared either State or imperial property.

The invasions of the Normans in the 9 th century must also have influenced the progress of forest policies. This latter influence was probably strongest in the northern part, while in the southern portions Roman laws remained in force, although the Roman policy which treated the forests as a res publica under the management of the administrators of public affairs fell to the ground. Here the forests became property of the communities without the socialistic limitations of the Mark and being left without restriction or control they were rapidly devastated.

The 5th century after Christ saw the Teutonic tribes, Visigoths and Burgundians, overwhelm the Romans who had for 500 years kept the Gallo-Celtic population under its rule. The conquerors subjugated and enslaved the Gauls and introduced the same economic and social institutions which had developed in Germany, somewhat modified by the existing Roman conditions. As in Ger- $r$ many the socialistic Mark was followed by the feudal system and the ban forests, the dukes becoming great landed proprietors or lords, and kings. Communal ownership was at first developed to such an extent that the Salic laws declared all trees which were not reserved by special sign as subject to the use of all and any of the Markers.

When Cloris, the king of the Franks, in the first 
decade of the 6th century defeated the Visigoths and took possession of the country (see p. 28), he found communal forests of the villagers (vicus), property of seigneurs (equites), royal forests and State forests, remnants of Roman origin. The latter properties he claimed for himself and divided two-thirds among his vassals; but the larger part of the other third became also gradually property of the nobility and church.

Not until the 12th century began the royal or State property to grow again in various ways, and in 1539 Francis I declared the same inalienable. But his successors paid little heed to this prohibition and, whenever financial troubles made it expedient, they disposed of some of their holdings.

By the ordinance of 1566 King Charles IX again declared the domain of the crown inalienable. Nevertheless he himself repeatedly sold parts of his domain. Henry III in 1579 renewed the ordinance of non-alienation and restored some of the lost parcels to the domain by the exercise of the royal right. Himself and his successors, however, continually broke this contract and the royal domain decreased while that of the seigneurs grew. Similarly to what happened in Germany, the church property was taken by machination or force to increase the holdings of kings or seigneurs. Nevertheless at the beginning of the revolution in 1789 the royal domain comprised about $1,200,000$ acres, producing a net income of 1.2 million dollars. In 1791 this royal property became the national domain and by further spoliation of church property and otherwise, attained an area of $4,300,000$ acres. In the law of 1791 a distinction was made between the inalienable 
domain which comprises roads, canals, harbors, etc., and the alienable national domain including the forest and other property derived from roval or crown domains which were entirely absorbed in it. To this national domain was added by the law of 1792 the forest property of the refugees of the revolution and finally when by the treaty of Basel (1795) the French frontier had been pushed to the Rhine, the total state forest comprised around 6,500,000 acres, nearly one-third of the total forest area.

But through sales and otherwise this area had by 1815 been reduced to $3,200,000$ acres, and during the period until $18 \% 2$ no stable policy regarding this property was maintained, the area being reduced to less than 2,500,000 acres. At present (1905) it comprises 2.9 million acres or less than 12 per cent. of the total forest area, 55 per cent. of which comes from the original royal domain, 22 per cent. from original church property and 23 per cent. from recent acquisitions, secured under the laws of reboisement of mountains, sand dunes, etc.

The communal property developed largely in a similar manner as in Germany from the Mark and through the feudal system, with its rights of user as a result. In the twelfth century the grandees or seigneurs were active in colonizing their domains, acquired as fiefs or otherwise, with serfs and others, giving them charters for villages with communal privileges and rights. Under this method another kind of communal forest property grew up, in which limitations and reservations of rights imposed by the seigneurs gave rise to many rights of user. These, as in Germany, were later frequently exchanged for territory, thereby increasing the 18 
communal property. But on the other hand "the right of the third" (triage), originating in the 14th century as an outgrowth of feudal relations, gave to the seigneur, whenever he wished to exercise it, one-third of the property free of all rights of user, and in this way the communal area was diminished until in 1667 the widespread abuse of this right led to an ordinance abolishing it. It was, however, re-established by the ordinance of 1669 in all cases where the forest had been gratuitously ceded by the seigneurs, or when the remaining two-thirds was deemed sufficient for the needs of the parish. Not until 1790-1792 was the exorbitant right finally abolished.

As an out-growth of the revolutionary doctrine, the most radical legislation in 1793 decreed presumptive ownership by the municipal corporations to all lands for which the claimant could not show a deed of purchase, excluding any title acquired as a result of feudal relations. The day of revenge of all old wrongs had come and, appeal to justice being useless, the municipalities increased their holdings freely. Although later legislation attempted to arrest this public theft and to restitute some of the stolen property, the communal forest area represents to-day a considerable contingent, namely 5 million acres or 23 per cent. of the total; private property with 14.8 million acres representing 65 per cent. of the total which is 22.7 million acres (17.8 per cent. of the total land area).

Rights of User had grown up in the same manner as in Germany, but efforts to get rid of them and to prevent their extension were instituted much earlier, Philip of Valois expressly forbidding such extension in 1646. Nevertheless they continued to grow so that by the mid- 
dle of the 18th century they were as general and afforded as great a hindrance to forest management as in Germany. The ordinance of 1669 also provided for the extinction of these rights, apparently without much success, and the troublesome times after 1789 increased their number. Only when the orderly regime follawing the reign of Napoleon gave rise to the Code Forestier (1827) was a systematic attempt for their extinguishment by the cession of territory and cash payment begun, and by this time the extinction may be considered practically concluded, at least for the state and communal property.

\section{Development of Forest Policy.}

As in Germany, the king, in addition to the ban and in addition to the rights of ownership to certain forest properties, had early asserted a superior right of the state to restrict the exercise of private property rights. Especially on land located in proximity to the royal woods, was the management of private property placed under supervision.

Ordinances like those issued by the German princes regulated the use of forests in France during the 12th to 17 th century; the first ordinance on record being issued by Louis VI (1215). These ordinances usually appeared under the name Le fait des eaux et forêts (the matters of waters and woods). The latter term was used exactly like that of the German Forst, designating the reserved territory under the ban, while bois is used to designate actual woodland (silva).

The roval forests were early placed under an administration, the principal officers of which were the grand 
maîtres des eaux et forêts, who were appointed to watch over the execution of the ordinances and the conduct of the officers in charge of the forest districts (maîtrise). Under these, with similar functions in smaller spheres, were maitres particuliers with lieutenants under them under various designations (Procureur $d u$ roi, greffier, gardemarteau, sergen du garde). A stamping hammer was employed for marking trees which defined the boundaries, or which were to be reserved in the fellings (kept by the gardemarteau). In addition to these regular officers there were employed a great number of capitaines des chasses whose functions, as the title indicates, related mainly to the chase.

$\checkmark$ By the middle of the 17th century the devastation of forests had progressed so far and the abuses in the management of the royal domain had become so evident that Louis XIV's great minister, Colbert, was induced to make the historical remark "France will perish for.lack of woods," and instituted a most searching investigation and reform which took shape in the celebrated forest Aordinance of 1669 ; this ordinance superseded all others. For this purpose he instituted in 1661 a commission which not only investigated conditions but was clothed with power to reform the abuses which it might discover. As the first act it recommended the ceasing of all cutting in the royal forests, and after deliberation and consultation with interested parties through eight years, the final law was enacted, a masterpiece whose principles and prescriptions to an extent have persisted into the 19th century. The commission from time to time made reports giving in detail their findings, and these form a most interesting record of conditions prevailing at that 
time. As one of the historians (Joubain) puts it, "the commissioners did not recoil before long hours of inspection nor high influence, they neither hesitated to declare against nor prosecute great and small alike, nor to pronounce a most serious sentence."

By this ordinance three special courts of adjudication $\checkmark$ in matters pertaining to the forests were established with special officers whose duties were carefully defined, namely the courts of the Gruries, of the Maitrises and the Tables de Marbre. The first named lower grade courts took cognizance of the lesser offences, abuses, wastes and malversations, disputes in regard to fishing or chase, and murders arising out of these; gruries being the woods belonging to individuals in which the jurisdiction and the profit from such jurisdiction belonged to the king, or at least to the seigneurs. The courts of the maitrise referred to the forest territory placed under administration of the maitres particuliers (Forstmeister) and were established near the many royal forests as courts of appeal in forest matters. A final appeal could be made to the tables de marbre (courts of the marble table), which also decided on the more weighty questions of proprietorship by whatever term held, and especially civil and criminal cases relating to the eaux et forets; the wrong doings in the discharge of official duties (abus), contraventions to the orders and regulations, misdemeanors or depredations (delit); and all kinds of fraud not included under those cited (malversations).

The whole country was divided into 18 arrondissements of grandes-maîtrises des eaux et forêts and these were divided into 134 maîtrises, each under a maître par- 
ticulier, with a lieutenant, a garde-marteau, a garde général, 2 arpenteurs and a number of gardes. A financial branch for the handling of moneys and the juridical branch represented by the three courts described above completed the organization, which lasted until the revolution.

The sale of royal forests was again forbidden, providing penalties for the eventual purchaser. Theft and incendiarism were severely punished and rules of management were established.

Clearings could only be made by permission even on the part of private owners. The methods of sale and harvest were determined. The prescriptions of older ordinances were renewed to the effect that at least 13 to 16 seed trees (baliveaux) per acre in the coppice, and 8 seed trees in timber forest were to be reserved in all forests without exception. Private owners were not to cut these seed trees before they were 40 years old in the coppice and 120 years in the timber forest, while in the public and church forests these seed treeswere treated like reserves. Similarly the prescription that no woods were to be cut before 10 years of age was revived from former ordinances, the time later (1787) being increased for public forests to 25 years. Also the obligation to keep one-fourth of the forest in reserve, which Charles IX had decreed in 1560, was renewed for the public forests (those belonging to corporations and other public institutions).

There was lively opposition to the enforcement of these prescriptions, especially where they interfered with property rights, nevertheless they persisted until the changes brought about by the revolution of 1789 . 
The law of 1791 removed all restraint and thereby inaugurated a most disastrous destruction and derastation against which legislative attempts of the republican government were entirely powerless. In $1801 \mathrm{Na-u}$ poleon reorganized the service, with five administrators, 30 conservators, 200 inspectors and 8,600 inferior officers. At that time it appears that the revenue from the public forest domain amounted to $\$ 6,000,000$, a sum justifying such elaborate organization. But otherwise the methods of Colbert's ordinance were revived.

In 1822 again a commission composed of foresters was instituted to revise the ordinance of 1669 which, here and there modified, had continued to be valid, except during the revolutionary period. The result of the work of this commission was the Code Forestier (1827) which is the law of the present day. In it principles are laid down under which the state, communal and other public forests are to be managed.

All forests submitted to the régime forestier, namely, the state and communal forests, are entirely managed by the state forest administration, the communities or other public forest owners paying for the service not to exceed 20 cents per acre, or 5 per cent. of the revenue. All jurisdiction and execution of forestry laws is in the hands of the officials of the Forest Administration. The foresters of the state have the exclusive responsibility of making and executing working plans, without interference by the municipalities after the plans have once been submitted and approved by them. The corporations have not even the right to appoint their own guards, all such being appointed by the prefects of the departments upon recommendation by the forest department. 
The fellings, usually performed by the purchaser, (the wood being sold on the stump) are supervised most rigorously, making even the smallest deviations from the conditions of the contract sale, which otherwise would only entail the payment of damage, punishable by fine; and the responsibility for any trespass which may occur on the land reaches 250 yards beyond the limits of the purchaser's territory, unless he gives proper waming and 1 tries to find out the perpetrators of the same.

Legal proceedings are brought before the courts of correction and are greatly simplified, as is customary in Germany. The rigor of the original propositions has been somewhat abated by the laws of 1859 .

The public forests may not be sold, mortgaged or divided and the product can be sold only through state foresters. As in the olden times one-quarter of the stands in the timber forests and one-fourth of the felling budget in the coppice is placed in reserve for urgent or unforseen needs.

In addition to these and other restrictions which refer to the public forests, there are prescriptions which apply to all woods in general. All foresters employed, even on private properties, have sheriff's power. Walking in the woods with axe, saw and wagon outside of the public roads which pass through them, is forbidden; the making of fires is forbidden; the making of fire lines 20 yards wide between private forests can be enforced by either owner, and railroads, along their rights of way, are required to make such. The setting of fires even within 200 yards of a wood is forbidden and the punishment of infractions of these laws is very severe. The rights of user are gauged by the administration accord- 
ing to the possible yield, even in private forests and are surrounded by many other restrictions; the wood is cut and delivered by the forest agents, and the rights can be extinguished by exchange of territory.

Thanks to the progress made in enforcing these rigorous laws, their necessity has almost vanished and at present relatively few infractions need to be investigated and punished.

The unity of France as compared with the infinite $\checkmark$ divisions in the provinces of Germany, permitted naturally a more uniform and persistent administration of all laws and policies. Thus the provisions of the ordinances of 1669 and the organization of the forest service then inaugurated persisted without essential modifications until 1827 (with the exception of an interregnum brought on by the revolution), and practically persists still, although changed in some details.

\section{Present Conditions and Administration.}

Of the 200,000 square miles of territory not quite 18 per cent. is wooded, and, with a population of nearly 40 million, only .6 of an acre per capita. In its present condition this area does not produce more than onethird of the home demand which requires an import in excess over export to the amount of about 25 million dollars annually on the average.

Since in 1892 there were still over 15 million acres of waste land, opportunity for a larger forest area seems to exist, and the existing forest area is capable of much larger production than the present, which is hardly 40 cubic feet per acre even in the better managed state and communal properties. 
Only 15 per cent. of the forest area is coniferous, 18 per cent. mixed conifer and broad-leaf forest and 67 per cent. pure or mixed broad-leaf forest. Of the $22 \%$ million acres hardly more than one-third, belonging to state and communities, are managed under working plans. The larger area is under coppice. According to the official publication Statistique forestière, by A. Matthieu, giving the details of the public forests for 1876 , the following relation of the different types of forest management existed in these forests.

Forest Conversion Coppice Pastures

State forests, per cent....45

Communal forests, do.....30

30

20 . 5

Total, per cent......36

1

67

Three-fourths of the communal and less than onefifth of the state's seed forest is managed under selection system. Combinations of farm and forest culture (sartage and furetage) are still quite extensively practised. The production of saw-timber under these practices is naturally small. Of the 40 cubic feet of wood per acre only 10 cubic feet are saw-logs and if the private forests were taken into consideration, the average product, on the whole would appear still smaller, the private properties being mostly small, poorly managed, and largely coppice. Neither the owners, nor their managers and guards have, as a rule, any professional education, although the means of obtaining it exist in the schools at Nancy and Barres.

At present the administration of the state forests is under the Minister of Agriculture as President of the Forestry Council, with a Director-General as Vice Presi- 
dent and technical head, and three Administrateurs Verificateurs généraux, chiefs of the three bureanx into which the administration is divided, each with two chiefs of sections, Inspectors, and the necessary office staff. For purposes of the local administration the forest area is divided into 32 conservations, each under charge of a Conservateur, equivalent to the German Oberforstmeister. These are again sub-divided into Chefferies or Inspections, two to twelve in each conservation, which are administrative units, under the supervision of Inspectors (200) and Assistant Inspectors (210). In addition, a special service for forest-organization and reboisement employs 14 inspectors and some 20 assistants. The forest districts or cantonments (ranges) finally are under the direct charge of Gardes généraux (162), with the assistance of Gardes généraux stagiaires (67) and underforesters (Brigadiers) or guards $(3,650)$; altogether a personnel of over 4,400 officials. While this is a larger force per acreage, yet the expense for personnel per acre is less than one-half that of the Prussian forest administration, and one-quarter of that in several of the other German state administrations.

The budget for 1905 places the total expenditure for the Forest Administration at $\$ 2,7 \% 0,000$ (95 cents per acre), of which 900,000 for reboisement and other improvement work. The receipts for the last five years have averaged near 7 million dollars, so that a net result of $\$ 1.75$ per acre seems attained, considering the expense of reboisement as new investment.

\section{Reforestation.}

The most noted work of the forest administration, and one for which it deserves high credit, has been that of the 
reclamation of waste lands, of which in 1879 it was estimated there were still 20,000,000 acres in extent. Especially the "reboisement" work in the Alpine districts as a result of the law of 1882 has become celebrated.

As late as the 18th century, after the forest area had already been reduced to a relatively small proportion, we find laws enacted encouraging clearings for farm use. The famine years of $1762-1766$ gave rise to such legislation; the "declaration" of 1766 exempted those who cleared land for farm purposes for 15 years from all taxes. As a result of this invitation some 750,000 acres were cleared, and the practice of clearing for farm use continued until the middle of the 19 th century. In this way, by inconsiderately exposing soil which would not everywhere be found adapted to farm use, wastes naturally existing were greatly increased. The movement for recovery of these waste lands dates som the beginning of the 19th century, and to-day reforestation by state, communal and private effort encouraged by legislative acts during the last sixty years, has restored more than 2,500,000 acres of lost ground to forest production.

There are four definite regions of large extent in which systematic effort in this direction has been made, namely, the sand dunes of Gascony, the Landes of Southwestern France, the sandy plains of La Sologne, the limestone wastes of Champagne, and the mountain slopes in the Vosges and Jura-Alps.

The sand dunes on the coast of France comprise round 350,000 acres, those on the coast of Gascony in Southwestern France alone have an extent of nearly 250,000 acres, these being the most important and hav- 
ing for a long time endangered the adjoining pastures and fields. It seems that the land occupied by dunes was originally forested and that these were created by deforestation.

As early as 1717 attempts at reforestation were made by the inhabitants, and from that time on small plantings were sporadically made. But the inauguration of systematic reforestation was begun only after a notable report by Brémontier, who in 1786 secured, as chief engineer of the department of Bordeaux, a sum of $\$ 10,000$ to be employed in ascertaining the possibilities of making a canal through the Landes and of fixing the dunes. As a result of this beginning, the method for their recovery having been by 1793 experimentally determined by Brémontier, 275,000 acres of moving sand have been fixed during the last century. The revolutionary government in 1799 created a Commission of Dunes, of which Brémontier was made president, and annual appropriation of $\$ 10,000$ was made, later (in 1808) increased to $\$ 15,000$. In 1817 the work was transferred to the Administration des Ponts et Chaussés. The appropriations were increased until in 1854 they reached $\$ 100,000$ a year, and in 1865 , the work being nearly finished, the dunes were handed over to the forest administration. There being still about 20,000 acres to be re- $\checkmark$ covered, this was achieved in 1865, when 200,000 acres had been reforested at an expense of about $\$ 2,000,000$, and an additional expense of $\$ 700,000$ to organize the newly formed Pine forests. These, at present, with their resinous products and wood are furnishing valuable material. An unfortunate policy of ceding some of these forest areas to private and communal owners was inaugurated just as the planting was finished, so that at 
present only 125,000 acres remain in the hands of the state. The returns from the sales, however, reimbursed the cost of the reboisement in excess by $\$ 120,000$, so that the state really acquired for nothing, a property, now estimated to be worth $\$ 10,000,000$.

To the eastward of this region of dunes stretch the so-called Landes, a territory triangular in shape, containing 2,000,000 acres of shifting sands and marshes, on which a poor population of shepherds (on stilts) used to eke out a living. In 1837 an engineer of the administration of bridges and roads (administration des ponts et chaussés), conceived the idea of improving this section by reforestation, and at his own expense recovered some 1,200 acres in the worst marsh by ditching and planting. The success of this plantation invited imitators and by 1835 the reforested area had grown to 50,000 acres. This led in $\mathbf{1 8 5 7}$ to the passage of a law ordering forestation of the parts of the land owned by the communities, the state at the same time undertaking the expense of building a system of roads and making the plans for forestation free of charge. The communities were allowed to sell a part of the reclaimed land in order to recover the expense. From 1850 to 1892 , private owners imitating the government and communal work, $1,750,000$ acres were covered with pine forests at a cost of $\$ 4.00$ to $\$ 5.00$ per acre, or, including the building of roads, a total of around $\$ 10,000,000$ had been expended. In $187 \%$ the value of the then recovered area was estimated at over $\$ 40,000,000$, this figure being arrived at by calculating the possible net revenues of a pinery under a 75 years rotation, which was figured at $\$ 2.50$ per acre with a production of 51 cubic feet per acre, and 200 
quarts of resin (at \$3). An estimate of recent date places the value of this area at $\$ 100,000,000$.

Centrally located between the ralleys of the Loire and the Cher near Orleans, lies the region of La Sologne, a sandy, poorly drained plain upon an impenetrable calcareous sub-soil giving rise to stagnant waters; this region too, had been originally densely wooded and was described as a paradise in early times; but from the beginning of the 17th century to the end of the 18th it was deforested, making it an unhealthy, useless waste. By $178 \%$, 1,250,000 acres of this territory had become absolutely abandoned. About the middle of the 19th century a number of influential citizens constituted themselves as a committee to begin its work of recovery, the Director General of Forests being authorized to assume the presidency of that committee. As a result a canal 25 miles in length, and 350 miles of road were built and some 200,000 acres, all non-agricultural lands were planted with Maritime and Scotch pine, the state furnishing assistance through the forest service and otherwise. A set-back occurred during the severe winter of 1879, frost killing many of the younger plantations, which led to the substitution of the hardier Scotch pine for the Maritime pine in the plantings. The cost per acre set out with about 3,500 two-year old seedlings amounted to $\$ 5.00$. An estimate of the value of these plantations places it at $\$ 18,000,000$ so that lands which 50 years ago could hardly be sold for $\$ 4.00$ per acre, now bring over $\$ 3.00$ as an annual revenue.

In the province of Champagne, South of Reims, arid lime-stone wastes of an extent which in the 18th century 
had reached $1,750,000$ acres are found. About $180 \%$ the movement for the recovery of these wastes began; first in a small way, gaining strength by 1830 after some sporadic experiments had shown the possibility of reforestation, and to-day over 200,000 acres of coniferous forest (mainly pine), largely planted by private incentive, are in existence. It is interesting to note that land which 50 years ago was often sold without measurement by distance, "as far as the cry would carry," and never for more than $\$ 4.00$ per acre, is to-day worth $\$ 40.00$ at a cost for planting of less than $\$ 10.00$. The stumpage value of a thirty years' growth is figured at from $\$ 50$ to $\$ 100$, the total forest area is valued at $\$ 10,000,000$ with net revenue from the 200,000 acres at $\$ 2.00$ per acre.

France is unfortunate in having within its territory the largest proportion of the area in Europe liable to torrential action. Not less than 1,462 brooks and mountain streams have been counted as dangerous waters in the Alps, the Cevennes and the Pyrenees mountains; or two-thirds of the torrents of Europe. An area nearly $1,000,000$ acres in extent of mountain slopes is exposed to the ravages of these waters by erosion.

Here the most forcible demonstration of the value of a forest cover in protecting watersheds was furnished by the results of the extensive forest destruction and devastation which took place during and following the years of the Revolution.

Long ago, in the 16th century, the local parliaments had enacted decrees against clearing in the mountains, with severe fines, confiscation and even corporal punishment, but during the Revolutionary period all these 
wholesome restrictions vanished; inconsiderate exploitation by the farmers began and the damage came so rapidly that in less than ten years after the beginning of freedom, the effect was felt. Within three years (1792) the first complaints of the result of unrestricted cutting were heard, and by 1803 they were quite general. The brooks had changed to torrents, inundating the plains, tearing away fertile lands or silting them over with the debris carried down from the mountains. Yet in spite of these early warnings and the theoretical discussions by such men as Boussingault, Becquerel and others, the destructive work by axe, fire and over-pasturing progressed until about 800,000 acres of tillable land had been rendered more or less useless, and the population of 18 departments had been impoverished or reduced in number by emigration.

The first work of recovery was tentatively begun in 1843 , but the political events following did not promote its extension, until in 1860 a special law charged the Forest Department with the mission of extinguishing the torrents. There were recognized two categories of work, the one, considered of general public interest being designated as obligatory, the other with less immediate need being facultative; the territories devastated by each river and its affluents on which the work of recovery was to be executed being known as perimeters. In the obligatory perimeters private lands were to be acquired by the state by process of expropriation, the communal properties were to be only for a time occupied by the state and after the achievement of the recovery were to be restituted on payment of the expense of the work, or else the corporation could get rid of the debt by ceding onehalf of its property to the state. 
In the facultative perimeters the state was simply to assist in the work of recovery by gratuitous distribution of seeds and plants or even by money subventions in some cases. It appeared hard that the poor mountaineers had to bear all the expense of the extinction of the torrents and much complaint was heard. In response to these complaints, in 1864 a law was passed allowing the substitution of sodding instead of forest planting for at least part of the perimeters, with a view of securing pastures, but this method seems not to have been successful and was mostly not employed. By the legislation of 1882, however, the complaints of the mountaineers were properly taken care of by placing the entire expense of the reboisement work on the state. The attitude of the mountaineers, which was at first hostile, due to the restriction of the pasture, has been overcome by the beneficial results of the work, and now the most hostile are ready to offer gratuitously their territory to the Forest Department. Wherever necessary the state has bought territory and from year to year has increased its holdings, and continues to acquire land at the rate of 25,000 to 30,000 acres per year, the budget of 1902 containing $\$ 1,000,000$ for this purpose. Altogether the state has, up to 1900 , acquired 400,000 acres, of which 218 ,000 have been planted, and it is estimated that about 425,000 acres more will have to be acquired. The total expense, outside of subrentions to communities and private owners, so far has been $\$ 13,000,000$, of which $\$ 5,000,000$ was expended for purchases, and it is estimated that round $\$ 25$ to $\$ 30$ million mare will be needed to complete the work. Of the 1,462 torrents there were in 1893, 163 entirely controlled, and 654 begun 
to be "cured." Among the former there were 31 which 50 years ago were considered by engineers incurable. It is estimated that with the expenditure of $\$ 600,000$ per annum the work may be finished by 1945 . The names of Matthieu and Demontzey, especially the latter, are indelibly connected with this great work.

\section{Forestry Science and Practice.}

Outside of this work of reclamation it cannot be said that the French foresters have developed forestry science or practice to a noticeable extent. The forest ordinance of 1669, attempting to improve the method of exploitation hitherto practiced, namely, the unregulated selection forest (jardinage), prescribed the method à tireaire, which consisted in leaving a certain number of seed trees per acre, no matter for what species or conditions of soil or climate, although, it seems that as early as 1520 one of the grandmasters, Tristan de Rostaing, had pointed out the faults of this method and recommended the method of successive fellings (shelterwood system). This prescription, applied uniformly as a matter of law, removed from the officials all spirit of initiative and desire or requirement of improving upon it. No knowledge beyond that of the law was required of them, hence no development of silvicultural methods resulted during the 1\%th and 18th century. The seed trees left on the felling areas grew into undesirable and branchy "wolves," injuring the aftergrowth, or else were thrown by the wind or died, and many of the areas became undesirable brush. Not until the first quarter of the 19th century was the change in this method proposed through men who imported new ideas from Germany. Large areas of 
coppice and of coppice with standards characterize the holdings of the municipal and private owners and the selection forest still plays a considerable part even in the State forests; the method of shelterwood in compartments, being still more under discussion than practice.

When the inefficiency of the methode à tirexaire was recognized the only remedy appeared to lie in a clearing system with artificial reforestation which was, however, only begun in the 19th century. Yet the success of the plantings in waste lands does not seem to have brought about much extension of this method to the felling areas. As late as 1862, Clavé, complaining of the conditions of silviculture in France, and of the ignorance regarding it, refers to the clearing system as méthode allemande, the German method. The shelterwood system, la méthode du reensemencement, which was introduced in theory from Germany by Lorentz in 182\%, was hardly applied until the middle of the century. Indeed, the promulgation of this superior method cost Lorentz his position in 1839, and other officers suffered similarly for this "German propaganda."

The only credit in silvicultural direction which belongs to the French foresters is the development of new and fertile ideas regarding the operations of thinnings; here the differentiation of the crop into the final harrest (le haut) and the nurse crop (le bas) (see page 105) and the differentiation of the operations, par le haut and par le bas, seems to have been for the first time described by Boppe in 188\%. Indeed, the theory of thinnings, at least, seems to have been well understood by Buffon, who advanced his theories in a memoir to the Academy of France in 1774, and gives a very clear exposition of the value of thinnings and improvement cuttings. 
In the direction of forest organization, it is stated by Clavé that in 1860 only 900,000 acres of the State domain were under a regulated management, namely 380,000 acres in timber forest and 520,000 in coppice with standards, leaving about $1,500,000$ acres at that time still merely exploited. The same writer states that of the corporation or communal forests hardly any are under management for sustained yield, and private forest management is not mentioned in this connection.

The method of forest organization employed, outside of the crude determinations of a felling budget in the selection forest, is an imitation of Cotta's area allotment, with hardly any attempt of securing normality.

\section{Education and Literature.}

In the earlier times the service established was often in incompetent hands; the offices of forestmasters were purchasable, were given to courtiers as benefices, and became hereditary. In all these higher offices professional knowledge was unnecessary. The ignorance of the subordinates was as great as that of their German counterparts, but lasted longer. Hardly any literature on the subject of forestry developed before the 19 th century and educational institutions had to wait until the beginning of that century.

The first, and up to the present, only forest school, came into existence after a considerable campaign, directed by Baudrillart, Chief of Division, Administration Générale des Forêts and professor of political economy, in the Annales Forestieres, the first volume of which appeared in 1808, and in other writings as in his Dictionnaire des eaux et forêts (1825), which led to the establishment of the forest school at Nancy in 1825. 
The first director of this school, Bernard Lorentz. having become acquainted and befriended with G. L. Hartig, and his assistant, afterward his son-in-law and successor, Adolphe Parade, having studied under Cotta (18171818) in Tharand, this school introduced the science of forestry as it had then been developed in Germany; but later generations under Nanquette, Bagneris, Broillard, Boppe and Puton, imbued with patriotism, attempted in a manner to strike out on original lines.

As a consequence of the "unpatriotic" German tendencies of its first directors the continuance of the school at Nancy was several times threatened, there being friction between the administration of the school and the service, which in 1844 came to a climax, agents in the service being employed without preparation in the school, a condition which lasted until 1856.

Even to date an active service of 15 years is considered equivalent to the education in the school for advancement in the service.

In 1839 Lorentz was disgracefully displaced, in spite of his great merits, because he advocated too warmly the application of the superior system of regeneration under shelterwood to replace the coppice and selection forest, an incident almost precisely repeated in the State of New York in abandoning its State College at Cornell University; and in other respects the two cases appear parallel. Parade, the successor of Lorentz being imbued with the same heretical doctrines was constantly in trouble and in 1847 a most savage attack in the legislature was launched which threatened the collapse of the school. This condition lasted until Parade's death, in 1864, when Nanquette assumed guidance of the school 
and steered in more peaceful waters by avoiding all ideas at reforms and innovations, but otherwise improving the character of the school and introducing the third year study. But he, too, was much criticized and in difficulties until 1880; nor was Puton, his successor, free from troubles until in 1889 a new regime and new regulations were enacted.

On the whole, the unfortunate uncertainty which beset this school and the methods pursued do not appear to have produced as efficient service and active development of the art as the more systematic and thorough training pursued by the Germans, if we may judge from results in practice and literature.

At the International Congress of Silviculture, convening in connection with the Universal Exposition in 1900, supposedly the best home talent was represented, but it cannot be said that anything new or striking or promotive of the art or science transpired. The desirability of establishing experiment stations outside the one in existence at Nancy (established in 1882) and the desirability of constructing yield tables required still arguments at this meeting.

The school is organized on military lines and lays more stress on drilling in practical work than on understanding principles. It has 12 professors, three for forestry, two for natural sciences, mathematics and law, one for soil physics and agriculture, one for military science and one for German. Only 12 students may graduate. A three year course, which includes journeys through the forest regions of France, leads to government employment; indeed, the first paid position as garde général stagiaire is attained after two years study before leaving school. 
For the education of the lower grades an imperial rescript ordered the establishment of several schools, which were, however, never organized. In 1863 were proposed and in 1868 opened four schools, where efficient forest guards were to secure some knowledge that would assist them to advancement; three of these schools persisted until 1883. In 1873 an additional school for silviculture for the education of underforesters was organized at Barres-Vilmorin, where annually six students are permitted to enter. This institution has persisted to date.

Until recently these schools were open only to candidates for government service.

The French forestry literature has never been prolific, and to this day occupies still a limited amount of shelf room. The first book on record is a translation of the well known volume of the Italian, Peter de Crescentiis, 1486. In the 16 th century we have reference to an encyclopædic volume, probably similar to the German Hausväter, by Oliver de Serres, Théatre d'Agriculture et Mesnage des Champs, in which a chapter is devoted to the forests. During the 18th century we have a number of high class writings, not by foresters, but by savants or students of natural history; the names of Réaumur, Mivabeaux, Duhamel and Buffon appearing with memoirs transmitted to the Academy of France, the highest literary and scientific body of men, on subjects relating to forestry. Réaumur in 1721 recommended the conversion of coppice forests into timber forests by a system of thinnings, but it is evident that his words were not heard beyond the Academy. Duhamel in 1755 repeats the 
recommendation of Réaumur in his three memoirs, Semis et Plantations, Exploitation des Bois and Traité de la Physique des Arbres, in which he exhibits considerable learning, while Buffon, the great naturalist, $17 \% 4$, presented several memoirs on forestry subjects full of excellent advice. Varennes de Fenille, another one of the Academicians, is on record with two memoirs on the management of coppice and timber forests. But among the foresters there seems not to have been suffcient education to appreciate these writings or to bring forth any contributions to the literature and art until the 19 th century. In 1803 we find the first encyclopædic volume in Traité de l'Aménagement des Forêts, which was followed in 1805 by a very incorrect translation of Hartig's Lehrbuch, both by Baudrillart, professor of political economy, who also published in 12 volumes his Traité Général des Eaux et Forêts. Dralet, a forester, $180 \%$, also brought out a treatise on forest management, which includes all branches of the subject.

In 1836 appeared Parade's, Cours Elémentaire de Culture des Bois, an excellent book, recording the teachings of Hartig and Cotta. This seems to have been all-sufficient until 1873, at least. Such things as yield tables are still \& mere wish, when Tassy wrote his Etudes, etc., in 1858, while de Salomon a little later reproduced Cotta's yield tables, and to this day this needful tool of the forester is still absent, at least in the literature of France. Nanquette, Broillard, Bagneris, Puton, Reuss, Boppe, all directors or professors at the forest school, enriched the French literature by volumes on silviculture and forest management, and Prof. Henry on soil physics. It is claimed by Guyot, that a truly "French science" (?) 
of forestry dates from Broillard's Cours d'A ménagement, in 1878. The latest contribution by G. Huffel, Economie Forestière, 1904, to be published in several volumes, promises to be of superior character. There should not be forgotten as among the non-professional promoters of forest questions, Chevandier, a chemist and manufacturer, who, in 1844, made investigations regarding the influence of irrigation on wood growth and on the influence of fertilizers, and in connection with Wertheim, laid the foundation for timber physics.

One monthly magazine, "Revue des Eaux et Forêts," not of the highest order or elaborate, if compared with the German journals, satisfies the needs of the French forest public and the books of professional character produced during the last century worthy of note will hardly exceed two dozen.

\section{Colonial Policies.}

The French have also extended their forest policy to their colonies in Algeria, Tunis, Indo-China, and Madagascar, although, at least in the latter, rough exploitation is still the rule.

Algeria, which was conquered in 1828 , is about fourfifths of the size of France, but only 5.5 per cent. is forested, largely with Aleppo Pine and various oaks, among which the Cork oak is the most valuable. Although the population does not exceed 4.5 million, import of wood from Sweden and elsewhere to nearly one million dollars in amount is necessary. The first advance of civilization led to wide-spread destruction of the originally larger, forest area; fire and pasture being specially destructive.

Before the French occupation the 7 million acres of 
forest were all communal property of the mussulmans, but by 1851 the larger portion had passed into possession of the state, much encumbered by rights of user.

In 1836 a forest administration for the state domain was inaugurated, but the unfortunate division of powers between military and civil authorities was a hindrance to effective improvement of conditions. The fire ravages of 1871 led to a thorough re-organization in $18 \% 3$ under the direction of Tassy.

Nevertheless, in 1900 Lefebrre, Inspector of Forests, in his book, Les forêts de l'Algérie, still complains that the forests are being ruined, especially by pasturing, the means allowed the administration being too niggardly measured.

The Forest Code of the home country and special laws enacted from time to time apply. The administration of the more than 5 million acres of state and communal forest is directly under the home department and is regulated in similar manner.

A re-organization and new legislation was enacted in 1903. This legislation relies still largely on the general principles of the Code of $182 \%$. The most interesting features are the provision for expropriation and addition to the state domain of forests, the preservation of which is of public interest, and the rigorous forest fire legislation, which permits to treat incendiaries as insurrectionists, makes the extinction of forest fires a duty of the forest officials and provides the forcible establishment of fire lines (rides) between neighbors.

In the forests placed under the forestry regime permits from the governor-general are required for clearing. For the administration of these properties the 
state receives ten per cent of the gross yield. Reforested hilltops or slopes and sand dunes are relieved from taxes for 30 years, burnt areas for 10 years.

In Cochin-China private forests, as well as public and state forests, are subjected to a policy of restriction in their exploitation. The forest domain is divided into reserves, about two hundred thousand acres, in which no cutting whatever is permitted and a second class in which permits for fellings are sold. In the absence of technical forest management the conditions have lately been reported as deplorable.

The first attempts at regulating forest use in these Asiatic possessions date back to 1862 , when exploitation was confined to delimited areas. The administration, however, remained inefficient, and under impracticable and heterogeneous orders, which were issued from time to time, devastation progressed with little hindrance.

In 1902 a re-organization took place and new regulations were issued, a director with four assistants being placed in charge under the Department of Agriculture. Restriction of the exploitation to diameter limits appears to be the most important innovation.

Since 1898 efforts at re-planting with teak are in progress on a small scale. 


\section{RUSSIA AND FINLAND.}

While Germany and France were forced into the adoption of forest policies through necessity, after the natural woods had been largely destroyed or devastated, Russia started upon a conservative forest management, long before the day of absolute necessity seemed to have arrived.

Indeed, even to-day Russia is one of the largest exporters of forest products in the world, its annual export amounting to over thirty million dollars; and a vast territory of untouched woods is still at her command, representing roughly two-thirds of the forest area of Europe.

Les Foréts de la Russie, Ministere de 'Agriculture, Paris Exposition $U$ wiverselle, rooo, $\$$. r $\phi 0$, gives a very detailed description of forest conditions, markets and management with a few historic points.

Russland's Wald, by F. v. ARNOLD, Berlin, 1893, pp. 526, contains bistoric notes and a profuse discussion of the law of 1888.

The Indwstries of Russia: Agriculture and Forestry, issued by the Department of Agriculture, Ministry of Crown Lands, at World's Columbian Exposition, translated by J. M. CRAwFond, 1893, contains a chapter on Forestry by Roudzskt and Shafranov, professors at the Forest Institute, in $35 \mathrm{pp}$.

Annual reports by the Russian Forest Administration are published since I866.

Four diffuse volumes, by John Croumbie Brows;, treat of Russian conditions, mamely,

Forests and Forestry in Poland, Lithwania, etc, 1885 ;

Finland, its Forests and Forest Management, 1883 ;

Forestry of the Mining districts of the Unal Mountain, 1884 ;

Forests and Forestry of Northern Russia, 1881.

Numerous articles and reviews by O. GusE, scattered through the German forestry journals, give insight into Russian forest conditions.

An excellent idea of prevailing forestry practice can be gained from an extended article by DR. Schwappach, Forstliche Reisebilder aws Rassland in Zeitschrift für Forst-und Jagdwesen, 1902.

For Finland an article by B. ERICSON in Forstwissenschaftliches Centralblatt, 1896, and another article by P. W. HANN1KasseN in Allgemeine Forst und Jagdzeitung, 1892, both native foresters, give considerable information. $806 \mathrm{pp}$.

Finland: Its Public and Private Ecomomy, by N. C. Frenericsen, 1902, 
While ostensibly the Czar is autocrat, the government is really under a bureaucracy, which is to a large extent corrupt, and hence the many good laws and institutions of which we read, may not always be found executed, as intended.

The country is divided into 98 governments or provinces, each under a governor, who is, however, largely dependent on the central power.

\section{Forest Conditions.}

Both the forest area and the ownership is very unevenly divided throughout the empire.

As in the United States the East and West are or were well wooded, with a forestless agricultural region between, so in Russia the North and the South (Caucasus Mountains) are well wooded, with a forestless region, the steppe, between. This leads, as with us, to an uneconomical exploitation of the woods, the inferior materials being wasted because not paying for their transportation.

The larger part of European Russia is a vast plain, excepting for the Ural Mountains, which form the Eastern boundary, and the Caucasus in the South.

Southern Russia, with the exception of the Caucasus, is largely prairie or steppe with hardly $4 \%$ of forest in the average, while some of the northern governments show $89 \%$ under forest cover. Here the crown owns all, or nearly all, while in the less wooded districts the State property is insignificant.

The forest area in European Russia comprises somewhat over 552 million acres, or $39 \%$ of the land area, and in Asia, where Russia occupies a territory nearly three times as large as its European possessions, namely 
6.3 million square miles; there exists a vast forested area, almost unknown as to its extent and contents, or value. This latter area is mainly located in Siberia, and although its extent is known to exceed 700 million acres, it is also known that its character is very variable, and much of it is "taiga" or swamp forest, much of it devastated, and much of it in precarious condition, fires having run and still running over large portions, destroying it to such an extent that in several of the provinces within the forest belt, the question of wood supplies is even now a troublesome one. The natives are especially reckless and devastation difficult to control. The railroad has only increased the evils.

Here, in Siberia, the first attempt at a management was made in 1897 in the government forests which are estimated at over 300 million acres; in addition about 400 million acres have been declared reserved forests.

In European Russia the population is over 110 million (nearly half only since 1861 escaped from serfdom), so that on the average the forest area per capita is only slightly over 5 acres, not more than in the United States, half of what is claimed for Sweden and Norway, although seven times as large as that of Germany or France.

It will be seen, therefore, that Russia, although still an exporting country, has reasons for a conservative policy, even if only the needs of the domestic population are considered, which alone probably consumes more than the annual increment of the whole forest area; and the consumption is growing with the growth of civilization as appears from the increase of wood consuming industries, which in $18 \%$ showed a product of 8 million 
dollars, in 1887 of $121 / 2$ million, in 1897 of 50 million dollars.

This assertion, that the era of over-cutting has actually arrived, may be made in spite of the stated fact, that in the northern provinces only two-fifths of what is supposed to be a proper felling budget, is cut and marketed.* The same reasons that operate with us contribute to wasteful practices, namely uneven distribution of forest and population.

The two most northern provinces of Archangel and Vologda, in size equal to all Germany, are wooded to the extent of 75 and 89 per cent. respectively, while the 14 northern provinces contain nearly one-half the entire forest area. Here the forest covers 64 per cent. of the land area, and nowhere below 20 per cent., and the acreage per capita ranges from 3 to over 200 .

\footnotetext{
*An idea of the productive conditions may be gathered from the estimates which have been made for the State forests and the operations in these.

In the two northern provinces, in which the state owns nearly the entire forest area it is estimated that 8 cubic feet per acre would be available felling budget, but only 10 per cent. of this is actually cut and sold. Outside of this territory the available felling budget is calculated at 24 cubic feet per acre, but only 60 per cent, or 11 cubic feet is being cut. Altogether in 1898 there were cut in the State forests (somewhat over 300 million acres), 1,860 million cubic feet, say 6 cubic feet per acre or 40 per cent. of the estimated proper felling budget.

An estimate of the cut in the communal forests with 12 cubic feet, in the peasants holdings with 20 cubic feet, and in the private forests with 40 cubic feet per acre, brings the total for the country to round 10 billion cubic feet, worth round 100 million dollars for stumpage. It is assumed that 30 cubic feet should be the annual increment per acre, when it would appear that only 70 per cent. of the increment is cut.

The cut in the State forests was sold for 21 million dollars (1898), or at an average of less than 1c. per cubic foot. The highest price paid in the Vistula district was 2.5 cents, which scales down to 1c. in Siberla and to one-third cent in the Caucasus. This refers to stumpage, nearly all sales being made on the stump to wood merchants by bids, the trees being marked in some parts, in others the area only being designated. The transportation is almost entirely by river. From 1889 to 1901 the net revenue from the State forests increased from 16 to 47 million dollars, while the expenditures dropped from 29 per cent. of the gross revenue to 18.4 per cent. The gross result is 46 cents per acre.
} 
In the more southern tiers (excepting the Caucasus) forest covers only $20 \%$ of the land area, sinking below $1 \%$ in the steppes and less than $1 / 2$ acre per capita.

The northern provinces, where the population is sparse, are the basis of an active wood trade for export, and the territory is being repeatedly devastated by fires, which sweep over large areas without check.

The northern forest, the most important economic factor, is composed principally of Scotch Pine with only slight admixtures of spruce, larch and fir, and more frequently White Birch. Open stand, comparatively poor development, and slow growth, characteristic of northern climate, reduce its productive capacity, while frequent bogs and other natural waste places outside of those produced by mismanagement reduce its productive area by not less than 20 per cent.

Toward the south, deciduous species become more frequent, oak becoming the prevaling timber and forming forests, with beech, maple, ash and elm as admixtures. As the plains are approached pure deciduous forest indicates the change of climate. The forest of the Caucasus is principally of coniferous composition.

\section{Ownership.}

The larger part of the forest area of European Russia is in control of the Crown or State, namely, nearly 380 million acres, or over two-thirds of the whole, and a similar amount in Asia, besides the so-called appanage forests of 14 million acres set aside for the support of the court.

This area (in Europe and Asia) of round 680 million acres (estimated) is, however, not the exclusive property 
of the State; only about 250 million acres are so claimed, the larger balance includes 170 million acres which are to be apportioned to the liberated peasants, 200 million acres in which the government is only part owner, or the ownership is in dispute; and the rest is only temporarily placed under the management or surveillance of the administration. Yet, $62 \%$ in Europe and $13 \%$ in Asia is exclusive State property. In 1903 the area under working plans of the Forest Administration, however, was only 58 million acres in Europe and 3 million in Asia. Of the State property in Europe $34 \%$ is spruce forest, $30 \%$ pine, and $26 \%$ mixed conifer forest. The Asiatic area is also over 80 per cent. coniferous.

The peasants own 40 million and other private owners some 110 million acres, and 10 million belong to corporations.

3. Development of Forest Policies.

The first record of attention to the woods as a special property dates from Michael, the founder, and Alexis, the second of the house of Romanoff, the latter becoming Czar in 1645. He it was who began to introduce Western civilization. He confined himself to regulating property rights, which up to that time had remained somewhat undefined, the forest, as elsewhere, being considered more or less public property. He issued deeds of ownership, or at least granted exclusive rights to the use of forests, somewhat similar to the banforests. Soldiers alone were permitted to help themselves, even in private forests, to the wood they required.

Protection against theft and fire was provided. 
The peasants being serfs were bound to the glebe and had, of course, no property rights, being maintained by the bounty of the seigneurs.

Alexis' successor, the far-seeing Peter the Great, who in his travels in Germany and other European countries had no doubt been imbued with ideas of conservatism, inaugurated in the end of the 17th and beginning of the 18th century a far-reaching restrictive policy, which had two objects in view, namely economic use of wood, which he had learned to appreciate while playing carpenter in Amsterdam, and preservation of ship timber, which his desire to build up a navy dictated. All forests for 35 miles along rivers were declared in ban and placed under the supervision of the newly organized Administration of the Crown forests. In these banforests the felling of timbers fit for ship building was forbidden. Minute regulations as to the proper use of wood for the purposes for which it was most fit were prescribed, and the use of the saw instead of the axe was ordered. These rules were to prevail in all forests, with a few exceptions, and penalties were to be enacted for contraventions.

This good beginning experienced a short setbrck under Catherine I (1725), Peter's wife, who, influenced by her minister, Menshikoff, abolished the forest administration and the penalties, and reduced the number and size of banforests. But the entire legislation was reenacted within three years after Catherine's death (172\%) under Anna Iranorna's reign, and many new prescriptions for the proper use of wood were added and additional penalties enforced.

At this time, under the influence of a "forest expert," 
Fokel, the increase of forest area in the poorly wooded districts by sowing oak, etc., was also inaugurated; and this planting was made obligatory, not only on the administration of crown forests, but also upon private owners, who in case of default were to lose their land and have it reforested by the forest administration.

These restrictions of private rights and the tutelage under the forest administration were abolished in toto by Catherine II, in 1788, and although it was reported by the admiralty, concerned in shipbuilding materials, that as a consequence the cutting, especially of oak timber, was proceeding rapidly, no new restrictive, but rather an ameliorative policy was attempted, as, for instance, prizes for plantations were offered in certain localities by provincial governors.

With the abolishment of the serfdom of the peasants in 1861, under Alexander II, these had lands allotted to them, and in the partition in some parts as much as 25 to $50 \%$ of the forest property was handed over to them. Immediately a general slaughtering, both by peasants and by the private owners, who had suffered by losing the services of the serfs, was inaugurated, leading to wholesale devastation.

Servitudes or rights of user also prevailed in some districts and proved destructive.

By 1864 complaints in regard to forest devastation had become so frequent that a movement for reform was begun by the Czar which led to the promulgation of a law in $186 \%$, followed by a number of others during the next decade, designed to remedy the evils. This was to be done by restricting the acreage that might be felled, forbidding clearings and giving premiums for good 
management and plantations. Finally, in 1875 , a special commission was charged with the elaboration of a general order which, after years of hearing of testimony and deliberation, was promulgated in 1888, a comprehensire law for the conservation of forests, private and otherwise.

The devastation and its evil consequences on waterflow and soil conditions had been especially felt in the southern districts adjoining the steppe, and these experiences were the immediate cause for the enactment of the law, which, however, was framed for the entire European Russia. In its application it makes distinction of four regions. In the far northern governments, densely forested $(60 \%)$ and thinly populated, the protective forest idea alone applies. In the Caucasus also none of the restrictions of private property except in protective and communal peasant forests apply, perhaps because the forest area (averaging not over 17\%) is there largely owned by members of the imperial house and by nobles. In certain districts adjoining the northern zone (with $37 \%$ forest) also only the last two types of forest, namely protective and communal properties, with institute forests added, are subject to the provisions of the law. The rest, a territory of over one million square miles with only $12 \%$ in forest, is subject to all the provisions of the law which treats State, imperial and private forests alike.

This law establishes as "protective forests," to be managed under special plans prescribed by the Crown forest department, those which protect shifting sands and dunes, the shores of rivers, canals and other waters; and those on the slopes of mountains, where they serve to prevent erosion, landslides and avalanches. 
Conversion of protective forests to farm use is forbidden, and the use of a clearing system, as well as pasturage and other uses supposed to be detrimental, may be interdicted.

In forests, which are not protective forests, conversion into farms or clearing is permitted, if thereby the estate is improved, e. g. if the soil is fit for orchards and vineyards; if fit for farm use, in which case, however, only temporary field use is permitted and the area is to be reforested eventually; if another formerly farmed parcel of the same size has been reforested at least three years prior to the proposed clearing; if in artificial plantations the growth is not yet 20 years old, and in a few special cases where property boundaries are to be rounded off.

The most interesting feature, because thoroughly democratic, is the creation of local forest protection committees, which are formed in each province and district, composed of various representatives of the local administration, one or two foresters included, the justice of the peace or other justice, the county council and two elected forest owners, in all nine to eleven members, under the presidency of the governor.

This committee is vested with large powers. It decides, without appeal, what areas are included in protective forests and approves of the working plans for these as well as for the unreserved forests; it determines what clearings may be made and exercises wide police powers with reference to all forest matters in co-operation with the Forest Administration, which latter has the duty of making working plans, free of charge, for the reserved forests, and at the expense of the owner for the privat, 
unreserved forests. Owners of the latter are, however, at liberty to prepare their own plans subject to approval. Appeal from decisions of the Forest Committoes lies through the Committee to the Minister of Crown lands and Minister of the Interior.

In addition to the above cited and other restrictive measures, some ameliorative provisions are also found. All protective forests are free from taxes forever; those artificially planted, for 30 years; also any expenses arising from measures ordered are chargeable to the Crown, if the owner objects; but in that case the Minister of Domains has the right to expropriate such properties, the owner having the right of redemption within 10 years by payment of the expropriation price and costs of the operations with $6 \%$ added.

Some of the best forest officials are detailed to give advice gratuitously to forest owners (forest revisor -instructors) and prizes are given for the best results of silvicultural operations. At the recommendation of the Forest Committees medals or money rewards or other distinctions are given to the forest guards and forest managers of private as well as public forests. Plant material is distributed free or at cost price, and working plans for protective forests are made free of charge.

The Imperial Loan Bank advances long term loans on forests, based upon detailed working plans made by the State, which insure a conservative management. In 1900 over $7,000,000$ acres were in this way mortgaged under such management.

The minutest details are elaborated in the instructions for the execution of this most comprehensive law. How far this law is really executed and what its results so far have been, it would be difficult to ascertain. 
In 1903 the application of the law was extended to the Caucasus, the Trans-caucasian and other southern provinces, but in the absence of suitable personnel and in a half civilized country, no result for the immediate future may be anticipated.

The surveillance of the execution of this law lies with the assistance of the Forest Committees, in the hands of the State Forest Administration.

This latter, centralized in the Department of Agriculture, consists of a Director General with two Vice-Directors and a so-called bureau of forests with seven division chiefs, a number of vice-inspectors and assistants. The local administration in the governments is represented by the Direction of Crown lands with a superintendent or revisor and several inspectors. The crown forests, divided into some 600 districts, are under the administration of superintendents, with foresters and guards of several degrees.

The whole service comprises at present about 3400 higher and over 30,000 lower officials.

Large as this force appears to be, it is small in comparison with the acreage, and inadequate. Although the net income from the 300 million acres of State forest which are being worked is now close to thirty million dollars, the pay of the officials is such as to almost force them to find means of subsistence at the cost of their charges. Perhaps nowhere else is there so much machinery and so much regulation with so little execution in practice.

\section{Education and Literature.}

The attempts at forestry education date back to the year 1732 when a number of foresters were imported 
from Germany to take charge of the forest management as well as of the education of foresters, each forstmeister having six pupils assigned to him. This method failing to produce results, the interest in ship timber suggested a course in forestry at the Naval Academy, which was instituted in 1800. Soon the need of a larger number of educated foresters led to the establishment of several separate forest schools, one at Zarskoye Selo (near St. Petersburg) in 1803, another at Kozlorsk in 1805, and a third at St. Petersburg in 1808. This latter under the name of the Forest Institute absorbed the other two, and from 1813 has continued to exist through many vicissitudes. Now with 15 professors and instructors it prepares in a four years' course for the higher positions in the forest service. "The history of this Forest Institute is practically the history of forestry in Russia."

A second school at Novo-Alexandria, near Warsaw, was instituted in 1860. In these schools, as in the methods of management, German influence is everywhere visible.

In addition to these schools, chairs of forestry were instituted in the Petrovsk School of Rural Economy in Moskau and in the Riga Polytechnic Institute, and also in seven intermediate schools of rural economy.

In 1888 ten secondary schools were established after Austrian pattern for the lower or middle service, rangers and underforesters; their number by 1900 being increased to 30 . These are boarding schools in the woorls, where a certain number of the students are taught free of charge, the maximum number of those admitted being 10 to 20 at each school. The course is of two years' duration and is mainly directed to practical work and 
theoretical study in silviculture. The total expense of such a school is about $\$ 3,300$, of which the State contributes $\$ 2,500$.

A number of experiment stations were established in various parts of the country by the Administration of Crown lands, and a very considerable and advanced literature testifies to the good education and activity of the higher forest service.

Two forestry journals, Lesnoj Journal (since 18\%0) and Lessopromychlenny Vestnik, the first bi-monthly, the latter weekly, besides several lesser ones, keep the profession informed.

There are in existence several general societies for the encouragement of silviculture. Probably the oldest, which ceased to exist in 1850 , was the Imperial Russian Society for the Advancement of Forestry which was founded in 1832. It published a magazine and provided translations of foreign books, among which the Forest Mathematics of the noted German forester König, who also prepared yield tables for the Society. (See p. 126.) A society of professional foresters was founded at St. Petersburg in 18\%1, another exists in Moscow, and recently two associations for the development of forest planting in the steppes have been formed.

Among the prominent writers and practitioners there should be especially mentioned Theodor Karlowitsch Arnold, who is recognized as the father of Russian forestry. He was the soul of the forest organization work, for which he drew up the instructions in 1845, and as professor, afterwards director, of the Institute for Agronomy and Forestry at Moscow since 185\%, he 
became the teacher of most of the present practitioners. Finally he became the head of the forest department in the Ministry of Appanages where he remained until his death in 1902. He is the author cf several classical works on silviculture, forest mensuration, forest management, etc., and, in conjunction with Dr. W. A. Tichonoff, published an encyclopædic work in three volumes. In the first volume, Russland's Wald (1890), which has been translated into German, the author makes an extended plea for improved forestry practice and describes and argues at length the provisions of the law of 1888 . In $\mathbf{1 8 9 5}$ he published a history of forestry in Germany, France and Russia. Of other prominent foresters who have advanced forestry in Russia we may cite * Count Vargaci de Bedemar, who made the first attempt to prepare Russian growth and yield tables in 1810 to 1850.

Professor A. F. Rudzsky, who was active at the Forest Institute until a few years ago, developed in his volumes especially the mathematical branches and methods of forest organization. The names of Tursky, Kravchinsky and Kaigodorov are known to Russian students of dendrology and silviculture, and among the younger generation the names of Morozov, Nestorov, Orlov, and Tolsky may be mentioned.

It is well known how prominent Russian investigators have become in the natural sciences, and to foresters the work of the soil physicists, Otozky and Dokuchaev would at least be familiar.

- According to notes kindly furnished by Mr. R. Zon of the U. S. Forest Service. 


\section{Forestry Practice.}

While then a very considerable activity in scientific direction exists, the practical application of forestry principles is less developed than one would expect, especially in view of the stringent laws. So far not much more than conservative lumbering is the rule.

Generally speaking, the State and crown forests are better managed than the private, many of which are being merely exploited; and in the northern departments large areas remain still inaccessible.

Some notable exceptions to the general mismanagement of private forests are furnished by some of those owned by the nobility, like those of Count Uwaroff with 150,000 acres under model management by a German forester, and of Count Strogonoff with over 1,000,000 acres under first-class organization with a staff of over 230 persons.

A regular forest organization was first attempted in the forests attached to iron furnace properties in 1840 . By this time some 100 million acres have come under regulated management, half of the area being crown forests. The method of regulation employed is that of area division and sometimes area allotment according to Cotta. In some regions a division by rides into compartments ranging from 60 to 4,000 acres, according to intensity of exploitation, has been effected. It is estimated that at the present rate of progress it would take 300 years to complete the work of organization.

The selection method is still largely employed, a felling budget by number of trees and volume being determined in the incompletely organized areas; while a clearing system with artificial reforestation is used in 
most cases where a complete yield calculation has been made. The rotations employed are from 80 to 100 years for timber forest, 30 to 60 years for coppice.

In the pineries the strip system in echelons is mostly in vogue, the strips being made 180 feet wide, leaving four seed trees per acre, and on the last strip, which is left standing for five years, this number is increased to eight which are left as overholders. This method seems to secure satisfactory reproduction. To get rid of undesirable species, especially aspen and birch, these are girdled. In spruce forest, 50 to 60 per cent. of the trees are left in the fellings, when after three to four vears the natural regeneration requires often repair, which is done by bunch planting; after eight to ten years the balance of the old growth is removed.

While for a long time natural regeneration was alone relied upon, now, at least, artificial assistance is more and more frequently practiced. Yet, although over 2 million acres were under clearing system, not more than $5 \%$ of the revenue, or $\$ 100,000$, was in 1898 allowed for planting as against $7.5 \%$ in Prussia; the total budget of expenses then remaining below 3 million dollars.

Within the last few years a new law (1897) inaugurates a method of securing the means of more intensive reforestation by making the wood merchants, who buy stumpage on government lands, clear the ground and plant it. To insure compliance with this condition, a deposit of $\$ 2$ to $\$ 4$ per acre is exacted. We are not informed as to results from this law.

The forest administration of the province of Poland, where the State owns over 1.5 million acres was for some 
time independent, but about 1875 was reorganized and placed under the central bureau at St. Petersburg. Although the forests of Poland are the most lucrative to the government and, with good market and high prices for wood which are now rapidly increasing, would allow. of intensive management, the stinginess of the administration, the low moral tone of the personnel and long established bad practice have retarded the introduction of better methods. The private forests of Poland comprise over 4.5 million acres, and are mostly not much better treated than the State forest: in the absence of any restrictive policy they have diminished by $25 \%$ in the last 20 years.

Considerable efforts have been made towards reforesting the steppes in southern Russia, first as in our own prairies and plains by private endeavor, but lately with more and more direct assistance of the State forest administration.

Since 1843 the government has had two experimental forest reserves in the steppes of the governments of Ekaterinoslav and Tauride, on which some 10,000 acres have been planted; the originator of this work being von Graff, a German forester, whose plantations, made with 8,000 plants to the acre, are still the best. Later the number of plants was reduced to one-half, and the results have not been satisfactory. At present the policy is not to create large bodies of forest, but to plant small strips of 20 to 80 yards in squares in regular distribution, which are to serve as windbreaks, and the result has been satisfactory, especially in the government of Samara. There are now annually 2,000 acres added to these plantations. 
The reclamation of shifting sands and sand dunes has also received considerable attention and, to some extent, the reboisement of mountain slopes in the Crimea and Caucasus. Of the former some 10 million acres are in existence and for 50 years sporadical work in their recovery was done, but only in 1891 and 1892, when two droughty famine years had led to an investigation of agricultural conditions was a systematic attempt proposed, and this was begun in $189 \%$. By 1902 some 80,000 acres had been fixed. In addition 1,500 square miles of swamps in Western Russia were reclaimed by extensive canals and recovered with meadow and forest at a cost of $\$ 300,000$, of which the Imperial Treasury paid one-third, the owners one-half, the local government the balance.

While rational forest management, as we have seen, is far from being generally established, the government tries at least to prevent waste and to pave the way from exploitation to regulated management.

\section{FINLAND.}

Finland, the "land of a thousand lakes" and of most extensive forests (over 50 per cent.), is hardly less important as a wood producer than Russia itself; its wood exports amounting at present to around $1 \% 0 \mathrm{mil}-$ lion cubic feet and over 20 million dollars in value, represent over 50 per cent. of its trade and its most important resource.

Settled in the 7th century by an Aryan tribe, the Finns, congeners of the Magyars, who subdued the aboriginal Laplanders, Finland became by conquest in the 12 th century, and remained for 500 years, a prov- 
ince of Sweden. In the wars between Sweden and Russia parts of this province were conquered by Russia, and finally in 1809 Sweden lost the whole, but the Finns succeeded in preserving national unity and partial independence under a constitution, adopted in 1772 and recognized by the Czar.

Finland stands very much in the same relation to Russia as does Hungary to Austria, the union being merely a personal one: the Czar is the ruler or Grand Duke, but the administration is otherwise largely separate from that of the empire, under a Governor-General appointed by the Czar and a Senate of 18 members at Helsingfors, with a national parliament of the four estates, nobles, clergy, burgers, peasants, which convenes every five years, the Czar having the veto power over its legislation.

The War Department of Russia, however, is in charge of military affairs, and other departments seem to be under more or less supervision of the Russian administration.

Of the 145,000 square miles, nearly one-third is occupied by lakes and bogs, marshes or tundra; all the rest but 16,000 square miles (10 million acres) which are farmland, is forestland, actual or potential; the total productive forest area being estimated at 57 million acres, or about 65 per cent. of the total area. The major part of this is located in the northern and eastern sections, where the population is scanty, agriculture little developed, and sand soils prevail. Not more than 2.5 million acres, mostly in the southwestern sections, are actually under cultivation; the population being short of 2.5 million. 
The rigorous climate makes a large consumption of fuelwood necessary and, since houses are also mostly built of wood, the home consumption is over 32 cubic feet per capita. Over 10 million cubic feet of pine are consumed in making tar, and a like amount for paper pulp.

The country generally is a tableland with occasional low hills. The forest consists principally of spruce (10 per cent. of the whole, mainly in the southeast) and pine, the latter a variety of the Scotch Pine (or species?), called Riga Pine which excels in straightness of bole and thrifty growth. Aspen, alder and birch, especially the latter, are considered undesirable weeds, and fire is used to get rid of them. Basswood, maple, elm, ash and some oak occur, and larch (Larix Sibirica) was introduced some 150 years ago.

Long, severe winters and hot, dry summers produce slow growth, the pine in the north requiring 200 to 250 years, in the middle sections 140 to 160 years to grow to merchantable size.

Fires, used in clearing, have from time to time run over large areas and have nearly killed out the spruce except in the lowlands, but the pine being more resistant has increased its area and in spite of the deterioration of the soil by fire reproduces well.

Originally the forest was communal property, but Gustav Vasa (1524) declared all forest and water not specially occupied to belong to "God, King and the Swedish Crown," although he allowed the usufruct to the people free of charge or nearly so. These rights of user are still the bane of the forest administration. 
Being left without supervision it mattered little who owned the land, the forest was ruthlessly exploited.

Not until 1851 did an improvement in these conditions occur when a provisional administration of the State forests was provided in connection with the Land Survey; but a rational organization materialized only after an eminent German forester, v. Berg, Director of the forest school of Tharand, had been imported (1858) to effect a reconstruction. His advice was, however, only partially followed and the organization was not perfected until 1869.

Almost immediately a powerful opposition to the administration developed, because it could not at once show increased profits, and the personnel which had been scanty enough, was still further reduced, the large districts into which the State property had been divided were still further enlarged, and to this day improvement in these respects has been only partial.

The State forest area situated mainly in the north and comprising nearly the total forest area, namely, between 35 and 45 million acres (variable because of clearing for farms and new settlements), contains about 15 million acres of bogs and moors and much other waste land.

This area was divided (1896) into 53 districts, the districts being aggregated into 8 inspections, and the whole service placed under a central office with a forest director and 5 assistants under immediate control of the Senate. The forest guards number 750 , their ranges averaging 50,000 acres, while the districts average 600,000 acres and several contain as high as 2.5 million acres; the Forstmeister in charge may live sometimes 
200 miles from the nearest town and 60 miles from the nearest road. His function is mainly to protect the property, to supervise the cutting and sales, and to teach the people the need of conservative methods. In spite of this insufficient service considerable reduction in forest fires and theft has been attained.

Beyond restriction of waste by axe and fire, and conservative lumbering of the State forest, positive measures for reproduction have hardly yet been introduced, both personnel and wood values being insufficient for more intensive management.

At present, with a cut hardly exceeding 100 million cubic feet, the revenue is still almost nominal, say $\$ 300,000$.

Selection forest is, of course, the rule, but since no trees are marked and cut less than 10 inch diameter at 25 feet from the ground (!), at least the possibility for improved management will not be destroyed when, through the exhaustion of the private forests and increased wood prices, more intensive management has become practicable.

Where the market is good, a clearing system with 100-160 year rotation is practised; on the clearings about 20 seed trees are left, and after 6 years the nataral regeneration is repaired by planting.

This latter method is especially prescribed on the government farms. These form an interesting part of the State property, some 900 small farms with woodlots aggregating over 500,000 acres, mostiy in the southern districts. These came into existence in the 17th and 18th centuries, being granted as fiefs to officers of the 
army as their only compensation. They reverted to the State and are rented for terms of 50 years upon condition that the woods are to be managed according to rules laid down by the State department, and special inspectors are provided to supervise this work. This system in vogue since 1863 at first met with opposition on the part of the renters on account of the impractical propositions of the department. At present the department manages many of these woodlots directly, as well as those which the clergy have received in lieu of emoluments.

Since 1883 a corps of forest surveyors has been occupied in making working plans based upon diameter accretion at the curiously selected height of 25 feet from the ground. A commission was also instituted some years ago to segregate forest and farm soils in the State domain with a view of disposing of the latter preparatory to improved management of the remaining forest area.

The State has also in a small way begun to purchase absolute forest soils in the southern provinces with a view to reforestation.

The private forest areas, located in the more settled southern portions are found mostly in small parcels and in peasants' hands, although the nobility also owns some forest properties, but the size of single holdings rarely exceeds 1,000 acres. These areas are mostly exploited without regard to the future, furnishing still four-fifths of the large export, and according to competent judges will soon be exhausted.

Although attempts have been made from time to time to restrict the use of private forest, practically little has 
been accomplished, and such restrictions as have been enacted are hardly enforced.

A law, enacted in 1886, forbids clearing along waters adapted to fishing, and orders the leaving of seed trees or "providing otherwise for regeneration," if more than 12 acres are cut at one time.

The method of utilizing the ground for combined forest and farm use, which is still frequently practised, was forbidden on the light sandy soils of the pineries, or was otherwise regulated. Forest fire laws are also on the Statutes.

Propositions for further restrictions made in 1891 were promptly rejected by the parliament.

Educational opportunities are offered in the Forest Institute at Evois, first established in $\mathbf{1 8 6 2}$ as a result of $\nabla$. Berg's visit, and recognized in 1874, which accepts new students only every second year for the two years' course. It has had a precarious existence, being left sometimes without students, and is naturally not of a high grade, practical acquaintance with woodswork being its main aim.

Since 1876 a school for forest guards and private underforesters has been in existence, where 6 students are annually accepted for a two years' course.

In addition there are two instructors provided by the government, wandering teachers who are to advise private owners. Premiums are paid for the best managed woodlots on the government farms.

The Finnish forestry association, which is in part of propagandist nature, was organized in 187\%. It supplies, besides an annual report, other forestry litera- 
ture, and employs an experienced planter to direct efforts at reforestation.

A forestry journal (quarterly) is also published, and a professional literature is beginning to start into existence.

It may be of interest in this connection to cite a rough calculation by Dr. Mayr of the available material in European Russia and Finland combined which he places at 4,500 million cubic feet, of which he considers one-half available for export.

It is impossible to prognosticate what position Russia and Finland, together the largest wood producers in Europe, will take in the future world commerce and how rapidly better practices, for which the machinery is already half started, will become generally adopted. At present, especially in Russia proper, the general corruption of the bureaucracy is an almost insurmountable obstacle to improvement. 


\section{THE SCANDINAVIAN STATES.}

Under the name of Scandinavian States we may comprise the countries of Sweden, Norway and Denmark, which were settled by the same group of German tribes, the so-called Norsemen; they originally spoke the same language, which only later became more or less differentiated. The settlement of the country by these tribes seems to have been accomplished in the main by the end of the 8th century; and the separation into the three several kingdoms in the ninth to twelfth centuries, during which time they were sometimes united, or at least under one ruler, sometimes at war with each other, and always torn by interior dissensions bordering on anarchy.

In the English language the Report on Forestry in Sweden, by Gen. C. C. Ardraws, U. S. Minister at Stockholm 18r2, revised 1900 . $35 \mathrm{pp}$. gives a statement of present conditions with historical notes.

A very good idea in detail of the wood trade of Swedea may be obtained from The Wood Industries of Sweden, published by TIMBER TRADES JOURNAL of London in 1896.

La Suede, son pemple et son industrie, by G. SuNDBARG, 1900, 2 vols., contains several pertineut chapters. It is an official work, very complete, and was translated into English in xgon.

The Economic History of the Swedish Forest, by GuNnar SchotTE, 1905. $32 \mathrm{pp}$., in Swedish, published by the forestry association, gives a brief account of conditions and data of the forestry movement.

Norway. Official publication for the Paris Exposition, rgo0, contains a chapter on Forestry by K. A. Fauchald, pp. 322-350, with a map of forest distribution.

Le Danemarc, Etat actuel de sa civilisation et de son organization sociale. by J. Carlsze, H. Olric and C. N. Starckz, rgoo, 734 pp.

Demmark, its kistory and topography. etc., by H. WerTRMBVRR, $189 \mathrm{~g}$.

Bidrag til det Danske Skovbrwgs Historie, by O. Lürkes, rgoo, was not eccessible to the writer.

A Dansh forester, Mr. Bendixsen has kindly revised the statements in this volume.

Extensive notes are found through the German, Austrian and Freach forestry journals. Especially an article in the Centralblatt für das gesammte Forstwesen, rgos (briefed in Forestry Quarterly, vol. III, p. aga) gives an extended account of forest conditions in Sweden. 
In 1397 by the Calmar convention, a more permanent union was effected between Sweden and Norway, lasting till 1448, when Norway became a dependency of Denmark; then, after another period of variable fortunes, Sweden about 1523 became an independent constitutional monarchy under Gustav Vasa, and Norway remained joined to Denmark under Frederick I.

Sweden then started on a career of conquest, being almost continuously at war with all her neighbors and especially with Russia and Poland, whereby, especially under Gustavus Adolphus and the adventurous Charles XII, her territory was greatly enlarged. With the treaties of Stockholm and Nystadt (1720 and 1721) she came into more peaceful waters, but permanent peace and a settled policy was not attained until the election of Bernadotte, one of Napoleon's administrators, to the kingship and the peace of Kiel in 1814, whereby Sweden became a constitutional hereditary monarchy in the modern sense. At the same time Norway was taken away from Denmark and forced to a union with Sweden, which persisted until this very year, when a peaceful separation took place by the action of the Norwegian people. The union has always been hateful to the Norwegians, although only the king and the department of foreign affairs (in which Norway is represented by a delegation from its Council) were in common, all other matters of administration being separate as well as the parliaments (Storthing in Norway, and Riksdag in Sweden).

Denmark did not become a constitutional monarchy until 1849. 


\section{SWEDEN.}

This country is of greatest interest to the world at large in forestry matters, because it has been and is still the largest exporter of wood and has only just fully waked up to its need for a conservative forest management: the law of 1903 promises to bring about very decided changes and to curtail the exports upon which other European nations so much rely.

Sweden, with 172,876 square miles, occupies the eastern two-thirds of the Scandinavian peninsular. It is not like Norway, a mountain country, but the greater part consists of low granitic hills. The mountain range which forms the boundary towards Norway falls off in a long slope towards the gulf of Bothnia and the Baltic sea, the coast being a broal 3 evel plain, with a series of islands, larger or smaller, girdling the outer coast line and forming an archipelago.

The country is cut into numerous water sheds, the many rivers (called elfs), furnishing means of transportation, expanding frequently into lakes (sjö) in the upper reaches and falling with cataracts into the lower plain, giving rise to fine water powers. One-ninth of the area (13 million acres) is cultivated in farms, the rest is barren or forest, the latter with some 50 million acres occupying $50 \%$. Of this the State owns or controls nearly $35 \%$; private owners and corporations the balance.

Half of the population of 5 million pursues agriculture, while iron manufacture and the lumber industry occupy one-quarter.

Of the three main divisions of the country, the south- 
ern, Götaland, is richest in low lands and agricultural soils, and, with a favorable maritime climate, farming is the main industry. Here a population of 50 to 60 , and in parts up to 190 per square mile is found. Beech and oak are here the principal trees with spruce occasionally intermixed.

In the central part, Srealand or Sweden proper, the forest region begins, with pine and spruce covering the granite hills and plateau; birch and other hardwoods, oak, beech, elm, basswood and poplar being found in the river valleys.

The third division, Norrland with the northernmost part called Lapland, where Laps and Fins form a not inconsiderable part of the population, is a vast, almost unbroken forest country, with hardly more than 3 people to the square mile. Although the northeastern part is a level coast plain, the climate is too severe for successful agriculture and the forest growth also is only short and of inferior quality.

Pine and Spruce with White Birch intermixed, is the timber. Towards the northern boundary the latter species increases, together with aspen, and finally the treeless tundra appears. A treeless alpine region occupies the northwestern frontier territory, fringed at lower elevations by a belt of birch.

The forest, nearly 10 acres per capita, plays an important economic rôle in the economy of Sweden not only because it covers such a large area (50\% of the whole and in some parts over $60 \%$ ), but because it has long been a prominent source of income. Especially after the abolition of the English import duties in 1866 a rapid increase in wood exports took place, until in 1900 
it amounted to over 54 million dollars (of which 12 million for woodenware), being the leading export article and representing over one-half of all exports.

In addition to this export which may represent at least round 300 million cubic feet of wood, there are about 50 million cubic feet of pulpwood and 150 million feet used for charcoal, besides the domestic fuel consumption. The total draft on the forest may be estimated to come near to 1,000 million cubic feet which is believed far in excess of the annual growth, much of the nearly 50 million acres of forest area having been devastated or deteriorated by axe and fire and being located in a northern zone where the growth is slow (1 inch in 12 to 15 years.). *

\section{Property Conditions.}

It was Gustav Vasa who in 1542 declared all uncultivated lands the property of the Crown. Parts of them were given to colonists and these as well as the resident population had the right to use the neighboring forest to supply their needs for wood and pasture. By the continued exercise of this right the forest became to be considered commons, proprietary rights remaining long in doubt. Finally a division came about, some of the lands becoming the property of the parishes, others of smaller districts (the hundreds), others again unencumbered property of the State.

The State now owns somewhat over 13 million acres, not including nearly the same amount of waste land, and controls more or less 4 million more, of which about 900,000 acres are ecclesiastical benefices and forests belonging to public institutions, and 2.7 million acres in State farms, which are rented. 
In Lapland the entire forest area used to belong to the State, but in order to attract settlers these were given forest property for their own use, from 10 to 100 times the area which they had cleared. This forest area the settlers disposed of to wood merchants (lumbermen), similar to the usage on the Pacific Coast, until the law of 1873 intervened, restricting the settlers to the usufruct alone, the government taking charge of the cutting of wood for sale and limiting the cut to a diameter of 8 inch at 16 feet from the base.

This interference with what was supposed to be private rights seems to have been resented and has led to wasteful practices, in the absence of a sufficient force of forest guards. Nevertheless the law was extended to Westerbotten in 1882.

In other provinces, Wermland, Gestrikland, etc., the government vested in the owners of ironworks the right to supply themselves with charcoal from State forests. But about the middle of the 19th century, when owing to railroad development in other parts, some of the ironworks became unremunerative and were abandoned, their owners continued to hold on to the forest privileges and by and by exercised them by cutting and sawing lumber for sale, or even by selling the forest areas as if they were their properties; and in this way these properties changed hands until suddenly the government began to challenge titles, and commenced litigation about 1896.

Grants of certain log cutting privileges on government lands were also made to sawmills in past times, usually by allowing sawmillers to cut a certain number of logs annually at a very low price. In 1870 these grants, which were very lucrative, were modified by substituting 
the right of an increased cut for a stated number of years at a modified price, after which the grant was to cease. In 1900 there were still some 300,000 acres under such grants.

No wonder that under these circumstances the value of the State forest property was in 1898 assessed at only $\$ 1.60$ per acre; the net income being $\$ 1,680,753$, or about 12 cents per acre; the expenditures for administration, supervision and forest school amounting to $\$ 123,659$, to which should be added an undetermined amount for the participation of the domain bureau, the agricultural department and provincial governments, all taking part in the forest administration.

Many of the towns and country districts have received donations of forest areas from the Crown, which have been a considerable source of revenue to them. The parish of Orsa, e. g., realized from its forest property some 2.5 million dollars, and other similar results are recorded.

These communal forests comprise somewhat over one million acres and are placed under management of local committees, with the governor of the province as chairman. The management consists in selling stumpage of all trees over 13 inches in diam. 5 feet above ground, to be cut by the purchaser under regulations.

In the latter part of the 19th century, as the sawmill industry expanded, many mill firms acquired wood-cutting leases for 50 year terms, for prices which were often realized from the forest in the first winter. At present longer leases than for 20 years are prohibited by law. The diameter limit of 12 inches, 18 or 20 feet above ground, was usually the basis of the leases; and as the 
owners could then lease away other sizes, it might happen that 2 or 3 persons besides the original owner would have property rights in the same forest. Of late years many of the mill owners have endeavored to get rid of the resulting inconvenience by buying the fee-simple of the land. This movement has resulted in the aggregation of large areas in single hands or more often in the hands of large mill companies.

By the acquisition of these properties a certain amount of cultivated land is usually included, which is then left to the former owner at a nominal rent, provided that he pays the taxes on the whole; thereby creating a class of renters in lieu of owners of farms.

The area thus privately owned mostly by sawmill companies must be over 25 million acres; the total private forest area, which includes the bulk of the commercial forest, is about 30 million acres, unreclaimable waste lands swelling the figure to over 50 million.

\section{Development of Forest Policy.}

From the times of Olaf Trătâlja, the first Christian king of Sweden (about 1000 A. D.), who gained fame by the part he took in exploiting the forests of Wermland, down to the 14th century Sweden suffered from a superabundance of forest. Nevertheless, by the end of that century restriction of the wilful destruction by fire was felt necessary, and an ordinance with that object in view was promulgated.

It is questionable whether this order had any effect in a country, where the homestead law provided, that a settler might take up "as much pasture and arable land as he could make use of, twice as much forest, and in ad- 
dition on each side of this homestead as much as a lame man could go over on crutches without resting."

Not till 1638 do we again find an attempt at forest conservancy, this time in the interest of supply of charcoal for the iron industry, by the appointment of overseers of the communal forests.

The first general forest code, however, dates from 1647 , which among other useless prescriptions made the existing usage of planting two trees for every one cut obligatory, and this provision remained on the statutes until 1\%89. In spite of this and other restrictive laws, exploitation by the liege lords and the communities continued until in 1720 a director of forests for the two southern districts, Halland and Bohus, was appointed, and at least in this part of the country the execution of the laws was placed under a special officer.

This appointment may be considered the first germ of the later forest department.

A policy of restriction seems to have prevailed during the entire 18th century, although it is questionable whether the restrictions were enforced since there was no personnel to watch over their enforcement, and the governors, in whose hands the jurisdiction lay, had other interests, more engrossing. A law, enacted in 1734, restricted the peasant forest owners in the sale of wood from their own properties, and in 1789 , this restriction and other supervision was extended to the nobility.

It appears that soon after this a considerable sentimental solicitude inside and outside the Riksdag was aroused regarding an apprehended deterioration of climate as well as scarcity of wood as a result of further forest destruction, in the light of present experience 
a rather amusing anticipation. These jeremiads, however, after an unsatisfactory attempt at legislation in 1793, led in 1798 to the appointment of a commission which reported after 5 years of investigation. A new set of forest regulations was enacted as a result in 1805 .

In further prosecution of these attempts at regulating forest use a commissioner, Prof. F. W. Radloff, was sent to Germany in 1809 , to study methods employed in that country. Long before that time, about 1760 , some of the iron masters, owning large forest areas had imported a commission of German forest experts (among them von Langen and Zanthier) with a view of systematizing the forest use; but apparently without result.

After much discussion of Radloff's report and consultation with the provincial governors, who suggested the propriety of different plans for different localities, new legislation was had in $1810,1818,1823$, and new regulations for the crown forests were issued in 1824 .

Yet at this very time not only the partition of the communal forests but also the sale of town forests was ordered; and this policy of dismemberment lasted till 1866 , over 1 million acres having been sold by that time. Nor was any diminution in wasteful practices to be noted as a result of legislation, and it seems that while on the one hand restrictive policies were discussed and enacted, on the other hand unconservative methods were encouraged. Indeed, in 1846, the then existing restrictions of the export trade were removed; apparently a reversion of restrictive policy had set in, and exploitation increased, in the belief of inexhaustible supplies. On the other hand, encouragement of reforestation was sought by giving bounties for planting waste land and 
for leaving a certain number of seed trees in the felling areas, also by paying rewards for the best plantations; all without result.

Meanwhile a check to the wood trade had occurred through the imposition of exorbitant customs duties by Great Britain, and at the same time the government imposed an export duty to discourage export from Norrland, and this was not abated until $185 \%$.

A further project of forest supervision was attempted through a report by a new commission appointed in 1828, which formulated rules for the control of public and private forests, and recommended the establishment of a Central bureau for the management of forest affairs, as well as the organization of a forest institute for the teaching of forestry. This Institute was established at Stockholm in 1828, but instead of organizing the burean the director of that institute was charged with the duties of such bureau. Again for years committee reports followed each other, but led to no satisfactory solution of the problems.

In 1836, however, a forestry corps (skogstaten) was organized for the management of the State forest under the direction of the Forest Institute, and as a result of persistent propaganda the central bureau (skogsstyrelsen) of forest administration was created in 1859 with Björkman at the head, charged with the supervision of all the State, royal, communal and other public forests and the control of private forest use.

The law of 1859, however, did not settle upon any new policy of control over private forest properties. Again and again forest committees were appointed to propose proper methods of such control, but not until 
1903 was a general law enacted, which was to go into effect on January 1, 1905.

Previous to this, locally applicable laws were enacted. In 1866 a law was passed which referred only to a particular class of private lands, namely those forests of Norrland which the State was to dispose of for ground rent, or which had been disposed of and the conditions of settlement had not been fulfilled.

Exactly in the same manner as the homestead and other colonization laws in the United States have been abused to get hold of public timber lands, so in Sweden large areas of government land had been taken up for settlement, but actually were merely exploited. It was to remedy this evil that in 1860 an examination of the public lands was ordered with a view of withdrawing portions from settlement and of making forest reservations. The royal ordinance of 1866 resulted, which was to regulate the cutting on settled lands and in such new settlements as were thereafter allowed.

This law prescribed the amount of yearly cut and required the marking of timber designed for sale by the government officers.

This "compulsory marking" or "Lapland" law was in 1873 extended to all private forests in Lapland, and to some other districts in $18 \% 9$.

Forest property in other sections of the country was either by royal ordinance or by special law placed under some restrictions. For instance in the districts Westerbotten and Norbotten a "dimension law" (1888) limits the diameter to which fellings are to be made ( 8 inches at 15 feet from base), and if the cutting of smaller trees is deemed desirable for the benefit of the forest these are 
to be designated by forest officials. Another law (1894) prevailed in Gotland, adding a reforestation clause, the governor being authorized to prohibit shipping of timber under 8 inch diameter and that not until new growth was established; or at least no new fellings may be made until this condition is fulfilled. The same law applies to sand dune plantations in other southern districts. Altogether one-quarter of the private forest property was in this manner subjected to restrictions, until the new law came into existence.

The law of 1903 came into existence as a result of a most painstaking, extended canvass by a legislative committee, appointed in 1896, which reported in 1899 , and of a further canvass by the Director of Domains, who reported in 1901. A large amount of testimony from private forest owners, sawmill men, provincial and local government officials, etc., was accumulated, and it may be reasonably expected that this new legislation will be more effective than most of the preceding seems to have been.

This law (1903) requires in general terms the application of forestry principles in the management of woodlands. For this purpose the felling plans are to be submitted for approval to a Forest Protection Committee, one for each province, which has surveillance orer all private forests, an institution similar to that in Russia; the dimension law and other provisions in the laws previously mentioned are revived ; clearings are forbidden and reforestation of old ones required, unless the ground is used for other purposes.

Where needful, pasturing is limited to certain lines. The Committee, or Forest Conservation Board, con- 
sists of three persons who are appointed for three years, one by the government, one by the County Council, one by the managing committee of the County Agricultural Society. In addition, where the communities desire, elected Forest Conservation Commissioners may be instituted to make sure of the enforcement of the law. The law does not prescribe detail methods as to how re-growth is to be obtained, but leaves these to be determined by the Board in consultation with the owners. If no agreement can be arrived at, or if the measures stipulated are not taken by the owner, the Board may enforce its rulings by Court proceedings, in which injunctions to prevent further lumbering, confiscation of logs, or of lumber, or money fines may be adjudged. The time of contracts for logging rights is reduced from 20 to 5 years. An export duty ( 4 to 8 cents per 100 cubic feet of timber, 8 to 14 cents per ton of dry wood pulp) is levied for the purpose of carrying out the law. Protective forests under special regulations are established at the alpine frontier and on the drift-sand plains.

The management of communal forest is to be placed under the State forest administration, the corporations paying 1.6c. per acre; but this feature does not seem entirely settled.

The State's property, as we have seen, occupies largely the commercially less desirable areas in Norrland and much of the waste land. Within the last 30 years a policy of purchasing and reforesting shifting sands and other waste property has increased its holdings. The purchases have added 600,000 acres at an average cost of $\$ 5.30$ per acre. In this way and by settlement of disputed titles, the State property has grown from 1880 
to 1900 by $45 \%$, to $13,325,000$ acres. The net revenue during that period increased from $\$ 300,000$ to $\$ 1,750,000$.

The earlier history of State forest administration we have given before.

The central forestry bureau as it exists now was organized in 1883 as the Domain Bureau in the Department of Agriculture and under it a forestry corps (skogstaten) (reorganized in 1890) has charge of the public forests and also of the forest control in the private forests where such control exists. For the purposes of this administration the country is divided into 9 districts each under an inspector (or öfverjägmästare); the districts are divided into ranges (revir), now 88, each under chief of range (or jägmästare) with assistants and guards(kronojägare); the nomenclature of the officers suggesting the hunt rather than the forest management. In addition 6 forest engineers are employed on working plans, engineering works, and in giring advice and assistance to private owners who pay for such service.

When it is stated that the ranges in the northern provinces arerage over 300,000 acres of public and 400,000 acres of private forest; in central Sweden 150,000 acres of public and 145,000 acres of private forest, and in the southern provinces nearly 55,000 acres of State and communal forest, it will be understood that the control cannot be rery strict. \&

3. Forest Administration and Forestry Practice.

The management of even the State forests can only be rery extensive. The State still sells mostly stumpage, only rarely cuts on its own account. The lumbering is 
carried on very much as in the United States by logging contractors and the river driving is done systematically by booming companies. Selection forest is still the general practice, now often improved into group system, although a clear cutting system with planting has been practised, but is supposed to be less desirable, probably because it entails a direct money outlay or else because it was not properly done. Of the State forests $90 \%$ are under selection system, and of the private forest $60 \%$.

In the southern provinces where planting is more frequently resorted to 2-3 year old pines and 2-5 year old spruces, nursery-grown, 2,000 to the acre, are generally used or else sowing in seedspots is resorted to, which is more frequently practised in the middle country.

Some 10,000 acres were, for instance, planted by the forest administration in 1898, at a cost of $\$ 2$ per acre, and the budget contains annually about $\$ 20,000$ for such planting.

That private endeavor in the direction of planting, has also been active, is testified by a plantation of over 26,000 acres, now 35 years old, reported from the Finspong Estate.

Complete working plans are rare even for the State forests, a mere summary felling budget being determined for most areas, the trees to be cut being marked.

Under instructions issued in 1896, working plans for the small proportion of State forest managed by clearing system are to be made. In these an area allotment method is employed with rotations of 100 to 150 years.

Forest fires are still very destructive, especially in northern Sweden, although an effective patrol system has reduced the size of the areas burnt over. The coni- 
ferous composition and the dry summers in the northern part together with the methods of lumbering are responsible for the conflagrations.

\section{Education and Literature.}

Among the propagandist literature, which had advanced the introduction of forestry ideas in Sweden it is proper to mention the writings of Israel Adolf of Ström, who after extensive travels in Germany established the first private forest school in 1823 and was instrumental in securing the establishment of the State Forestry Institute in Stockholm.

In regard to education a most liberal policy prevails.

At the Institute the tuition is free and in addition 4 students receive scholarships of 250 dollars per year, appointment to assistantships follows immediately after promotion, and in 10 years the position of jägmästare may be attained. The number of students is limited to 30 .

The director of this school is also general adviser in forestry matters. Besides the director six professors are employed. The course at this school is two years of 11 full months.

There are now a higher and a lower course, the former requiring previous graduation from another preparatory forest school, either the one at Omberg (founded 1886), or that at Kloten (1900), where a one-year course, mainly in practical work, is given.

For the lower service there are not less than 6 schools in various parts of the country each with one teacher and assistants, managed under a chief of range. In these not only is tuition free but 10 pupils receive also board and lodging; the course lasting 8 months. 
These schools prepare for State service, as well as for managers of private forests.

A forest experiment station was organized in 1903, an independent institution in the Domain Bureau, under the direct charge of a practitioner. Every third year a commission is to determine what work is to be undertaken. The appropriation, which so far is hardly $\$ 5,000$ per annum, will not permit much expansion. The first number of its publication, Meddelanden fron Statens Skogs Förs8ksanstalt, was issued in 1904.

That a forestry public exists in Sweden is attested by a forest association with an organ Skogsvårds Föreningens Tidskrift, which was founded 3 years ago (1902). The journal is the continuation of an earlier magazine, Tidskrift for Skogshushällning, a quarterly, begun in 1869 and running until 1903. A periodical for rangers, etc., is also in existence under the name of Skogsvännen.

In 1902 also, there was formed a lumberman's trust to regulate the output, which the forest owners proposed to meet by an associated effort to raise stumpage charges. The attempt of the lumbermen to restrict the cut in 1902 was, however, a failure, for the export of that year was $10 \%$ larger than the previous year.

It is expected that the new law will have the tendency of decreasing the cut and of inaugurating a new era in forestry matters generally.

\section{NORWAY.}

Norway, occupying with 124,445 square miles over one-third of the Scandinavian peninsular, is for the most part a mountainous plateau with deep valleys and lakes. Its numerous fjords and water ways make 
accessible much of the interior mountain forest, yet a large part of the inland area still remains inaccessible and trackless.

More than $75 \%$ of the country is waste land and only $3 \%$ in farms, leaving for the forest area $21 \%$ or hardly 20 million acres. The distribution of this forest area is most uneven. The bulk and the most valuable portion of it is found in the south-eastern corner around Christiania in eight counties, in which the forest per cent. exceeds 40 to 50, with conifer growth (pine and spruce) up to the 3,000 foot level. Again in the three counties around Trondhjem a large and important forest area is located at the head of the fjords. But the entire western coast and the higher elevations are devoid of valuable forest growth and the northern third of the country (north of the Arctic circle) is mostly heath and moors with only $7 \%$ wooded, mainly birch growth of little commercial value.

The commercially important forest area is, therefore, locally confined and comprises probably not more than one-half of the whole stated forest area. It is estimated that one-half of the territory has to import its lumber, one-quarter has sufficient for home consumption, and the excess which permits exportation is confined to the last quarter. This export, which amounts to around 18 million dollars ( $40 \%$ of the total export) is estimated to represent only one-fifth or one-sixth of the total cut, which is stated as about 500 million cubic feet, while the annual growth is estimated at less than 350 million, showing considerable overcutting.

Scotch Pine is the principal timber, with Norway Spruce, more or less localized; oak, ash, basswood and 
elm occurring sporadically, and White Birch being ubiquitous.

Forest property developed on the same lines as in Sweden and in other European countries, hence we find State, communal, and private property.

When in the ninth century the commons were declared the property of the king, the rights of user, both to wood and grazing, were retained by the märker, and the so-called State commons (almenninger) remain to date encumbered by these rights, similar to conditions in Sweden. From the end of the 17th to the middle of the 19th century it was the policy of the kings to dispose of these commons whenever their exchequer was low, and the best of these lands became, by purchase, property of the districts (bygdealmenning), provinces, city and village corporations.

At present the State owns, largely in the northern districts, somewhat over 2 million acres, of which half a million consists of encumbered commons; the district commons comprise 460,000 acres, and private properties, together with institute forests, represent about $85 \%$ of the total.

By the middle of the 17 th century the coast forest of oak had been cut out by Dutch and English wood merchants who had obtained logging privileges. There are records which would make it appear that at least some of the now denuded coast was forested in olden times. The development of the iron industry increased the drain on these supplies, which forest fires, insects and excessive grazing prevented from recuperating. 
As early as the middle of the 16 th century we find attempts to arrest the devastation by regulating the export trade and supervising the sawmills, but probably no result was obtained, and in 1795 at least, the unreasonable obstructions to export were removed. The sawmill privileges, under which English lumbermen held large areas for long terms and devastated them without regard to the impractical regulations, were not ended until 1860. The wood industries were then relieved entirely from restrictions, and forest destruction progressed even more rapidly with the increased facilities for transportation.

An abortive attempt at real forest management was made in the 18th century when the two famous German foresters, von Langen and von Zanthier were called upon to organize forest management in Sweden, Denmark and Norway during the years 1736 to 1740 . The department which resulted from this visit was, however, abandoned in 1746, and Zanthier, who with 12 assistants had organized it, returned to his country, the sole survivor, the others having succumbed to scurvy.

The first worthy modern effort at reform dates from the Forest Act of 1863 which stopped the extension of ruinous rights of user, and placed the management of the State and other public forests under an effective department. In 1892 the export from the three northwestern provinces which are only thinly forested was prohibited, and in 1893 an act was passed enabling municipalities to protect themselves against destruction of forests needed for protective purposes.

Many of the State forests are so burdened with rights of user, which were granted to help in developing the 
country, that the financial results of the forest administration and the conditions of the property are most unsatisfactory.

The forest service is in the Department of Agriculture under a director (Skovdirector) and 4 Forstmeister or inspectors with some $3 \%$ executive officers and 360 rangers under various names, who are in charge of forest districts, plantations and nurseries. The districts are so large, sometimes several million acres, and many of them so inaccessible that only the most extensive management is possible; the officials being poorly paid and poorly educated, the management is not of a high order.

Besides a "forest engineer," who is a public lecturer, the officers of the forest department are under the obligation of advising private forest owners in their management, under contracts somewhat similar to the present practice of the U. S. Forestry Bureau, the owners agreeing to follow the advice.

Since 1860 the State has begun to purchase forest lands for reforestation in the forestless districts and where, for protective reasons, it is desirable. In late years regular appropriations of $\$ 15,000$ to $\$ 20,000$ were annually made for this purpose, besides extraordinary grants. In this way, the cut-over lands, neglected by their owners, are cheaply acquired by the State. Besides its own planting, the State assists private owners by advice and money grants in reforesting their waste lands.

The communal forests are under government supervision; they are usually worked under plans and under supervision of foresters with a view to supply the needs of the community. Only when the area is more than sufficient may they obtain the right to cut for sale outside 
of their parish; on the other hand all fellings may be prohibited by the government, if this is found desirable. Private forests are without government supervision.

The silvicultural system is most generally the rough selection forest or an approach to group system, relying upon voluntary reproduction entirely. Management is much hampered by rights of user to certain dimensions, and in the more distant districts by the difficulty of disposing of any but the best sizes. An orderly organization is still almost unknown. The stumpage is sold and removed by the buyer and the axe is still mainly used.

Higher forest schools there are none, but three schools for the lower grades exist. Until recently the higher foresters had to get their education in Germany, or in the Swedish Forest Institute at Stockholm; but in $\mathbf{1 8 9 7}$ a chair of forestry was instituted in the Agricultural college at Kristiania.

Altogether forestry is on a low level in this country.

A forestry society was organized in 1898 , which publishes a journal, Tidskrift for Skogsbrug, and employs a forester, paid by the State, to give professional advice. The subject is being brought into the primary schools and the efforts to improve conditions are widespread.

\section{DENMARK.}

Denmark with 15,290 square miles and 2.5 million people (or 164 to the square mile) is largely a farming country, 80 per cent. being productive, and only 5.4 per cent. of it, or less than 600,000 acres being under forest, and this also mostly on soil capable of farm use.

In addition there are about 75,000 acres of heaths and 
other wastes in process of reforestation. Especially on the island of Jylland, on which the capital, Copenhagen, is situated, the forest area is now increasing by planting. The balance, or nearly 20 per cent., consists of heaths, moors, peatbogs and sands.

The peninsula of Jütland is a large sandbank with extensive sand dunes, shifting sands, heaths and moors, some of which probably were never forested, while a hardwood forest of beech and oak covered the better soils.

While originally Beech was and is still the predominant timber $(60 \%)$ with considerable additions of Oak (7\%) and other hardwoods, a conifer forest of Spruce and Pine covering more than $20 \%$ of the forest area has been established by planting.

This planting has been mainly done on the dunes and sandwastes, of which there were some 20,000 square miles in existence, and in the reclamation of the extensive heaths and moors or peat bogs, which are found especially on the west coast and in the northern Limfjord district, occupying one-sixth of the unproductive area.

As was natural, the forest stocked on good farm land had to yield early to plow and pasture. Attempts at conservative use of the forest area date back to 1557 when Christian III issued a forest ordinance directing his vassals or liege lords to permit the peasants to secure their domestic wood requirements at a cheap rate, but not to permit cutting for sale or export, and reserving to himself all returns from such sales. There were also regulations for the pasture, especially as to goats, and 
for the use of the mast, which then formed more than one-quarter of the income from the royal forests.

In the 18th century the need of forest management was recognized, and in 1763 the two eminent German . foresters, von Langen and von Zanthier (see $\mathrm{A} 83$ ) were invited to visit Denmark and Norway (see above) with a view of organizing such management. In 1760 eight young Danes were sent to von Langen in Wernigerode to study his methods for three years, and these with the two German foresters returned in 1763, and under the direction of von Langen organized the Seeland forest areas and started the first plantations of conifers, which are now the pride of Danish foresters.

In 1781 the State forests were altogether placed under an organized administration.

By the beginning of the 19 th century the reduction of forest areas had progressed to such an extent that in 1805 a law was enacted providing that the then existing forest area containing beech and oak should be maintained forever, or at least that for any new clearing an equivalent area be planted to forest. This law was perhaps the result of a journey in 1802 to Germany made by two leading officials of the forest department, German influence through Cotta and Hartig being at this time visible everywhere.

Other restrictions in the disposal of peasants' farms or woodlands and in the manner of farming the large estates otherwise than by renting to farmers, were also enacted in order to secure stability of the peasant class and to prevent aggregation of large estates. In this reform movement the name of Count Reventlow appears as the leading spirit, as Chief of the State forest department. 
The forest area, which until 1820 was on the decrease, has since that time increased steadily, and is especially now increasing through reforestation of waste lands.

At present the most intensive forest management is practised in the State forest as well as in the communal and private forest areas which are largely in farmers' woodlots since the law forbids the union of small farms into large estates. There is little communal property, and large private estates are also rare. The State owns somewhat over $21 \%$ of the forest area or 142,000 acres, of which $60 \%$ is coniferous. Excepting in the beech forest most of the timber is of the younger age classes below 60 to 80 years, and it is anticipated that the cut will have to be reduced, and the import of wood and woodenware which is now over six million dollars in value will have to be increased.

Artificial reproduction is the most general silvicultural practice except in the beech forest which is reproduced naturally after preparation of the soil and sowing acorns for admixture at the same time, spending altogether $\$ 12$ to $\$ 15$ per acre in this preparation. Since 1880 thinnings have been based on the idea of final harvest trees; they are begun in the twentieth to thirtieth year and are repeated every three years, aided by pruning. Then in each subsequent decade the return occurs in as many years as the decade has tens. Especially in the direction of thinnings the German practice and even theory is outdone, the thinnings being made severer and recurring more frequently.

More than a hundred years ago the State began the 
reclamation work of the dunes and heaths, but it progressed more actively only since the sixties of last century, when through the effort of a State engineer, Capt. Dalgas, an association was formed for the reclamation of heaths and moors. A small subrention of $\$ 600$ started the work of the association under the advice of Staats planteur (State forest planter) Jensen Tusch in its useful campaign. The State subvention now amounts to about forty thousand dollars annually, and the success of the association has been such that it has become almost a fad for large land owners and others to buy up these waste lands and have them planted through the agents of the Heath Association. The planting is mainly of Spruce in plow furrows at a cost of $\$ 10$ to $\$ 12$ per acre; 60 to 80 year old stands of earlier plantings testifying to the possible results.

In the last 40 years nearly 200,000 acres of heath have been planted, of which over one-half are to the credit of the association.

For the education of the higher grade foresters a department of forestry (now with two professors) was instituted in the Royal Veterinary and Agricultural High School at Copenhagen in 1869, with a course of five years including one and a half year of practical work. This education is given free of charge.

The Heath Association educates its own officers, including in their subjects the management of meadows and peatbogs.

A Forestry Association, composed one-half of forest owners, with its organ Tidskrift for Skovvaesen, in existence since 1888, and a valuable book literature, in 
which the problems of the heath are especially fully and authoritatively treated, places Denmark in the foremost rank in the forestry world.

Among the prominent contributors are to be mentioned, besides Reventlow and Dalgas, P. E. Müiller, well known by his discussions of the problems of moor soils. From 1876 to 1891 he issued a magazine, in which Oppermann contributed a history of Danish forestry. The latter author in co-operation with Hauch published in 1900 a Hand-book of Forestry. 


\section{THE MEDITERRANEAN PENINSULAS.}

Geographically, and to some extent climatically, the three peninsulas of the Mediterranean Sea, the Iberian, Italian, and the Balkan, are situated alike. Their people, if not in race, are in temper and characteristics, and in their political economy more or less alike. They represent the oldest civilization in Europe, and in their long history have been frequently in collision with each other. Their forests, through centuries of abuse, are wherever accessible, in poorest condition. Long-continued political disturbances, which have prevented peaceful development, and poverty, have been the greatest hindrances to economical reforms which, like the recuperation of forests, require sacrifices. Ancient rights of user, and the necessity of politicians to respect them are also responsible for the fact that, while praiseworthy attempts in legislation have been made, execution has been usually lagging behind.

The accessibility to sea, readily permitting importation, the temperate climate, the simple life and abstemiousness of the people, and the lack of industrial development have made the deficiency of wood material leso felt than it would otherwise be, but the detrimental influence of forest destruction is being repeatedly experienced in floods and drouths.

While Italy is now a united country, and only two peoples, Spain and Portugal, occupy the Tberian peninsula, the Balkan peninsula is occupied by eight separate peoples, if we include all the country south of the

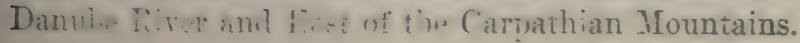




\section{TURKISH AND SLAVISH TERRITORIES.}

The Turks for centuries warred with, had under vassalage or otherwise controlled, and misruled all the Slavis States, (as well as Macedonia and Greece) a territory of around 170,000 square miles and 16,0100,000 people until, by the Congress of Berlin (1878), ending the Russo-Turkish war, the former were recognized as independent kingdoms, namely Bulgaria, Servia, Montenegro, Roumelia and Roumania, while Bosnia-Hercegovina was placed under Austrian administration (see pages 144 and 155).

With the exception of Roumania, these people are still in the lower stages of civilization, the countries undeveloped, the forest still serves largely for the mast and pasturage, probably less than 24 per cent. of the country being forest covered, mostly with deciduous trees, oak, beech and walnut, etc.

Roumania alone has systematically taken advantage of her freedom from Turkish rule in developing a modern civilization, and can also boast the beginning of a forestry system.

Macedonia, and the other parts of Turkey in Europe (Albania and Thrace) with 67,000 square miles and $5,000,000$ people, contain large areas of untouched forest (not less than 5,000,000 acres in Macedonia alone*) with valuable oak and walnut, which have remained unused owing to their inaccessibility and the undesirability of developing them under Turkish rule. Where accessible, the forest is maltreated or destroyed.

Bulgaria, to which, in 1885 , Eastern Roumelia was attached, represents now 38,000 square miles and

*Lacretelle, Rapport sur les forêts de la Macédoine, 1898. 
3,000,000 people, under a German prince as king since 188\%. The forest area* of 7.5 million acres (30 per cent. of the land area), mostly deciduous (oak, beech, walnut, etc.), and largely confined to the mountains, is one-half in communal ownership, one-sixth in private hands, mostly small woodlots, and one-third State property; but ownership rights are still much in doubt. The only efforts to improve forest use have been a law ordering the stoppage of rights of user, substituting money payment (10 per cent. of value), and another restricting the diameter to which the most valuable export timber, walnut, may be cut. Political exigencies, absence of an organization, and other undereloped conditions have largely prevented enforcement of these laws. The export of walnut has increased fourteenfold in the last four years.

Servia, a kingdom with 19,000 square miles and 2,000,000 people, has over 42 per cent. (five million acres) still in untouched forest, with valuable oak and walnut, the forest being mainly used for hog-raising. The inaccessibility of the forest area is such that the needs of a large part of the population are more cheaply supplied by importation, which amounts to over one million cubic feet. Lately the first attempt was made by the Minister of Agriculture to bring order into the forest administration by importing German foresters.

Roumania, $\uparrow$ with 48,000 square miles and nearly $6,000,000$ people, under the capable administration of a Hohenzollern prince, King Charles, was in Roman times as Dacia felix one of the most prosperous provinces, half of it hilly and mountainous, the other half in the rich al-

* Forsticlie Rurdschan, 1903.

4 Die forstwirśsinafilichen Verhältnisse Rumdniens, Von Mihail Vasilescu, 1894.

Wotice sur les forets de Rowmanie, in Statistica padurzlor Statulin. 1903. 
Iuvial valley of the Danube, now largely deforested. The hill and mountain country was until the end of the eighteenth century still well wooded. A rapid depletion then took place by the demands of the Turkish markets, until now not quite 17 per cent. (according to others 20 per cent.) of the area is forested, and the universal rights of user, which made commons of the woods, have naturally led to widespread devastation in the accessible parts. In 184\%, the National Assembly attempted regulation of the cut and of the rights of user, but with little effect. In 1894, the total area had decreased to less than 5 million acres (according to others 6.7 million acres) of which two-fifths is in private hands, twofifths State property and Royal forest (formerly, until 1863 , in the hands of the monks), the small balance belonging to communities and institutes. In the higher mountains, fir and spruce with some pine and larch form the forest; oak and beech occupy the middle altitudes and the hill country. The private forest of small owners is being rapidly depleted, only the State forest and that of large proprietors being in good condition.

In 1863 , when the cloister property was secularized and taken over by the state, the rights of user in this property were suspended, and sales at auction to contractors were inaugurated, under condition that a certain number of seed trees per acre be left. There was little enforcement of this rule.

The first comprehensive law organizing the State property and inaugurating a protective policy was enacted in 1881. This law recognized State, Royal and Communal property as of public concern, and also placed such private property under supervision as was situated on 
steep slopes, near watercourses, and near the boundaries (of strategic importance). These areas, coming under the protective policy, comprise 84 per cent. of the whole forest area. They were not to be cleared except by special permit, and not to be exploited except under specially approved working plans. In 1885, three French foresters were called in to organize a State forest department and to inaugurate the making of working plans. The personnel (25 inspectors and 89 district officers) being insufficient, and wood prices low (the income from state property being not over $\$ 400,000$ ), the progress of the work was slow. Although, in 1894, the income had doubled, the administrative forces had not been enlarged to any great extent (137 foresters of various grades), and by that time only 150,000 acres had been brought under working plans. By 1900 about 200,000 acres of State property, or 14 per cent., and 500,000 acres of private forest, or 22 per cent., were organized in some fashion. Lack of means of transportation, however, prevents a really well regulated management. Altogether only 65 per cent. of the State property is accessible so that it can be worked, and the working plans consist mainly in leaving a number of seed trees.

In 1889, a Forestry Association (Progressul Silvic) was formed, which with its organ, Revista pâdurilor, pushes the propaganda. In 1890, an energetic Minister of Domains, Carp, sought strenuously to bring improve ment into the situation. A budget of $\$ 500,000$ for foresters' dwellings was secured to bring the forest managers into closer contact with their charges, a planting fund of $\$ 100,000$, later increased to $\$ 140,000$ per annum, was voted, and reforestation and reclamation of sand dunes was begun. A forest improvement fund was 
inaugurated in 1892 by setting aside 2 per cent. of the gross forest yield. But, in the political struggles, Carp's party was displaced, and, depression in agricultural prosperity causing financial distress, an era of increased exploitation followed, so that the export of forest products (mainly to Greece, Italy and France) which had been declining, rose again to about eight million dollars annually. The financial embarrassment of the State led even to a proposition to sell State forests, but, before contracts for this purpose were consummated, relief came and the danger was averted.

The State cuts about 22,000 acres annually, yielding about $\$ 1,000,000$, the administration costing (in 1903) $\$ 240,000$, leaving a net yield of 30 cents per acre. In 1898, the Forest Department, in the direction of Domains under the Ministry of Agriculture consisted of a Forest Director with 156 foresters academically educated (mostly in France, and since 1892 in the Agricultural Institute at Bucharest), and over 2,500 underforesters and guards. Of some 30,000 acres of sand dunes, one-half belonging to the State, about 18,000 acres have been recovered by planting Black Locust, and some 9,000 acres of plains country have been reforested, for which 330 acres of nurseries furnish the material. In spite of all these efforts excessive pasturing, although forbidden in the State forest, and fires continue to devastate the property.

Private forestry is, of course, much less developed, yet some large properties (Princess Schoenburg, with 20,000 acres) are under efficient German forest management. Here money is spent on developing means of transportation, and a better revenue is secured than in the State forests. 


\section{GREECE. •}

\section{Forest Conditions.}

Although certain districts, like Attica, were already practically denuder in Plato's time, there is little doubt that originally the whole of Greece with small exceptions was a continuous forest. The destruction of the forest, protected by thousands of gods and nymphs in holy groves, proceeded slowly under the regime of the ancient Greeks, until the fanaticism of the Christian religion led to a war against these pagan strongholds, and the holy groves were reduced by axe and fire. Turkish misrule, for centuries, overtaxation, reckless cutting, extensive herding of goats and sheep, and fires hare reduced the forest area until now it occupies only 12 or 14 per cent. of the land area (25,000 square miles). In 1854, a survey developed about 2 million acres of woodlands (probably an excessive figure) for the now 2.5 million people, while 67 per cent. of the surface is a useless waste, and only 20 per cent. under cultivation, so that the general aspect of the country is desolate. The many islands are entirely deforested, and so are the seashores. "Where in olden times dense shady poplars stood, now only infertile sand and dreary rock waste remain."

The forest in northern and middle Greece is confined to the two mountain ranges which run parallel, north and south, with Mt. Olympus (nearly 9,000 feet) and Mt. Pindus (6,000 feet) the highest elerations. The large plains of Thessaly and Boeotia are forestless. So is the

Dr. ChLoros, Waldverhältnisse Griechenlands. Thesis for the Doctorate at Munich. 1884. 45 pp.

Anderuind, Mittheilungen über die Waldverhälınisse Griechenlands. Allgemeine Forst-und Jagdzeituag. 1884. 
large Arcadian plateau of the Peloponnesis, and the other smaller, hot but fertile plains and plateaus. The most valuable conifer forest is found on the higher ranges between the 2,500 and 5,000 foot level, below the snow-clad mountain tops, where especially two species of fir, Abies Apollinis and Abies regince Amatiae (a species remarkable for its sprouting habit), with other firs and several species of Juniperus and Cupressus, form sometimes extensive forests. Other common trees are chestnut, sycamore, several species of oak and poplar, and, on the coast, Pinus halepensis.

The firs occupy about 35 per cent. of the forest area, oaks and deciduous forest 45 per cent. Among the forest products which are exported, we find galls, vermilion. and sumach prominent.

With the exception of the Pindus range, which is composed of metamorphic rock, a poor, dry limestone is characteristic of the country except where fertile, alluvial and diluvial deposits cover it in valleys along the coast. The climate is, however, so favorable that even the poor soil would readily reclothe itself if left alone. The winters are short, hardly three months, and with hardly any snow or ice except on the high mountains, making the vegetative period nine months. Tenperature ranges from 20 to 106 degrees $\mathrm{F}$.; rainfall average $400 \mathrm{~mm}$.; the summers are, to be sure, rainless and dry, but the other seasons are humid, somewhat less than in middle Europe. Rapid growth is the result of these conditions. But the continued pasturing of goats and sheep-some six million-prevents any natural reforestation. Increased taxation on this industry has had no effect, and the practice of permitting the people 
to gather dry wood for fuel is an incentive for making dry wood by setting fires, which also serve to improve the pasture; perhaps nowhere are forest fires more frequent, in spite of heavy penalties. That a baneful influence on the water condition and river flow has been the result is historically demonstrated by Chloros*.

In the mountains some fine and quite extensive bodies of fir still exist, lack of transportation having preserved them. Elsewhere the rights of user, and the herding of goats are so well established that reforms appear, indeed, difficult.

Firewood, 3 loads for each person, supposed to be taken from the dead or otherwise useless trees, and small dimension material is free to all. For the right to cut workwood, the government charges a tax of 25 to 30 per cent. of the value of the material, the price for this being annually determined. On the material cut in private forests, the government also levies a tax of from 12 to 18 per cent. of its value. This pernicious system of promiscuous cutting leads to the most wasteful use imaginable, not only high stumps, but large amounts of good material are left in the woods so that it is estimated that hardly 50 per cent. of what is cut is really utilized. The cut, as far as the tax gives a clue to it, amounts to round 2.7 million cubic feet workwood, but with the firewood included it was estimated that near 90 million cubic feet are cut annually. Importation to the amount of 1.5 million dollars, mostly from Austria and Roumania, makes up the deficit in work material, especially for the box factories which manufacture the packages for the

\footnotetext{
* See Allgemeine Forst-wnd Jagdzeitung, 1884, p. 183 ff, and 188\%, p. 327 ff. for interenting details.
} 
large export of currants, some 2 million boxes. The tax during the decade from 1862 to 1871 produced an annual income of $\$ 600,000$, a little less in $\mathbf{1 8 9 5}$.

The forest has been from olden times, and is now almost entirely, State property (some 80 or 90 per cent.) and in nearly all the remaining, private, communal and cloister property the State has a partial ownership or supervision. The waste land of probably 3 million acres extent also belongs to the State, the whole State property covering over 30 per cent. of the land area.

2. Development of Forest Policies.

The history of the country has been so unfortunate, and political conditions so unsettled that only lately efforts at improvement in economic conditions could hope to receive attention. For centuries after Greece had become a Roman province (146 B. C.), it changed rulers, Romans, Byzantines, Franks, Venetians following each other, until, in 1446, it came under the Turkish yoke. In 1829 freedom, but no settled order as yet, was attained through the assistance of Great Britain, France and Russia, and the elected kings, Otho (of Bavaria), Alfred (of England) and George (of Denmark) successively tried to secure social order and efficient constitutional government.

By the time this new era had arrived there was probably little raluable forest worthy of the name left, except in the inaccessible mountain districts.

A first definite attempt to regulate matters was made by Otho, who being a German, took a personal interest in this forest property, and instituted for each province forest inspectors (dasarchys) under one chief inspector, with forest guards to prevent devastation by fire and 
theft. The mistake was made of employing in these positions superannuated Bavarian army officers, who were merely a burden on the treasury. No management or even regular fellings were attempted. The population could, as before, supply its needs upon permits, always granted, from the governor of the province, one of the forest guards being supposed to vise these, and to see that the wood was properly employed, not, however, to supervise the cutting.

In $187 \%$ further legislation was had, instituting in the Ministry of Finance, a forest inspector, technically trained, with two other inspectors, also technically trained, to superintend the outside work. A forest survey was begun in 1879 , but interrupted in 1880 for lack of funds and personnel. The same law placed the duty of guarding the State property in the hands of the general police or gendarmerie, 50 officers and some 340 guards, and during the fire danger (June to October) 110 more, being detailed for this service under direction of the Minister of War. The pernicious permit system, however, was continued.

Dr. Chloros, who obtained his education in Germany, became finally Forest Director and is responsible for securing further legislation in 1888, the object of which was, as a first step towards improrement, to surrey and delimit and round off the State property. It provided that enclaves, and all absolute forest soil was to be expropriated. If no amicable agreement with the owner could be reached, the price was to be determined by the net yield which had been obtained from the property auring the last five years, capitalized at 5 per cent. No attempts at an efficient organization or change of the destructive permit system were made. 
By general law the State has the right to surveillance of private property, although the extent of this right is not fully defined. The government may take for its own use, by paying for it, upwards of one-sixth of the annual cut; it collects a tax of 12 to 18 per cent. for al] workwood cut; it forbids the pasturing of woods that have been burned within 10 years, and obliges all owners of over 1200 acres to employ forest guards. 'This and other interference with property rights naturally acts as deterrent to private forest management. A notable exception is the small private royal forest property near Athens, which, since 1872 under a Danish forester, appears to have been managed under forestry principles.

A thorough re-organization of the forest service was to be effected in 1893, when 20 district foresters were employed, the number of forest inspectors was increased. to four, and a regular Division of Forestry was instituted in the finance department. The general police or gendarmerie was continued as forest guards. Until a native personnel could be educated by sending young men to Germany, foreigners were to be employed for the making of working plans.

Yet in 1896 the then Director of the Forest Department, a lawyer, still complains of the absence of a proper organization and of any personnel with forestry knowledge. Apparently no progress had been made. In that year, however, the gendarmerie was to be replaced by forest guards ( 52 superior and 298 subaltern) who were to be appointed from graduates of a special secondary school, which had been instituted at Vytina some two years before. This replacement could, of course, not be effected at once, since hardly more than 25 could be 
graduated annually, hence even this improvement in the lower class police would not be completed for six or eight years. No steps had been taken to educate officers for the higher grades, and in this direction propositions merely were discussed.

In 1899 a change in the permit system was made, but hardly for the better, justices of the peace being empowered, under certain conditions, to issue such permits. Nor do we find in 1901 anything more than expressions of good wishes, and desire for further legislation, besides some attempts at popular education through the formation of tree-planting associations under the patronage of the Crown Princess.

While the government makes these efforts to improve conditions, the indifference, stupidity, cupidity, and malevolence of the people, and the long established abuses prevent rapid progress at reform.

\section{ITALY.}

The efforts to secure improvement in the treatment of forest resources have been more active and strenuous in Italy than in Greece. They were induced especially by the urgent need of protecting watersheds, the rivers throughout Italy having been turned into torrents by deforestation. But owing to the weakness of the governmentand to poverty theactual execution of the very good laws has lagged behind. Indeed while ample legislation has been enacted, the people, overburdened with debt, and needing the small income that can be derived from pasturing or renting the pasture in the woods, make it 
difficult to carry on any reform, and the enforcement of the laws has again and again led to serious trouble. "Forestry is a sore point in the national economy of Italy, as it involves sacrifice of money and time." Italy, therefore, like ourselves, is still in the transition period from forestal rapine to forest culture.

Densely populated (33 million on 119 thousand square miles), with nearly one-third of its area unproductive, or at least unused, and one-quarter of this almost or quite beyond redemption, no country offers better opportunities for studying the evil effects of deforestation on soil and waterflow. As a result of the combination of geology (slates and limestones), topography (steep slopes), climate, and forest devastation or destruction, mainly by pasturage of goats (two million), the Italian rivers are invariably flooded in March and mostly dry in summer; the melting of the snow coinciding with the heary spring rains turns them into raging torrents (fumare), silting over the fertile lands in the valleys andoccasioninglandslides in the mountain country, where extensive tracts are nearly bare of vegetation. Especially the rivers around Bologna, which in

Bolletino ufficiale per l'amminstrazione forestale Italiana.

Direzione generale dell' A gricoltora: Relazione interno all' amministrazione dei boschi domaniali inalienabili.

Various essays by Prof. VitToRio Perowa of Vallambrosa in German magazines ; notably in Allgemeine Forst-und Jagdzeitung, 1882, 1888.

Archeologia forestale. Dell'antica storia e ginrisprudenza forestale in Italia. A. Di BrRenger, 1859.

Marrin, Revista forestale.

Italy. By Prof. W. DeEkr, 1904.

$1 l$ rimboschimento dello Apennino meridionale, by LuIG Savastano, 1898. An exceedingly well written popular treatise on silviculture, which gives also briefly insight into forest conditions and forest practices.

I boschi e la nostra politica ltaliana, by BertagnolL, 1889.

Italia moderna, 1904, article by Lunabows. 
1897 again caused damage in excess of one million dollars, are dreaded.

\section{Forest Conditions.}

Situated similarly to Greece as regards accessibility and climate, and similarly torn by wars and political strife, and in unstable conditions for centuries, Italy has in proportion to population, if not to area, reduced her forest resources even more than Greece; less than onethird of an acre per capita remains, with a total of cbout ten million acres, or 14 to 16 per cent. of the land area, and this includes much useless brushland. Apparently, if the uncertain statistics may be relied upon, a reduction of several million acres has taken place even since 18\%0. Some 15 million acres of waste land and 8wamps offer ample opportunity for increasing this forest area without infringing on the 22 million acres of usefully employed agricultural soil.

Of the forest area, 25 per cent. is to be found in the Alps, about 50 per cent. on the Apennines, the one mountain range which forms the backbone of Italy; less than one-third is distributed over the plains, and the balance is found on the islands, especially Sicily, which is a hill and mountain country, once magnificently wooded, now largely denuded (4 per cent. wooded) and Sardinia, which, with nearly 45 per cent. under forest, is the best wooded part of Italy, although the condition of the forest is here no better than elsewhere.

With the exception of the slopes of the Alps (2.5 million acres of spruce, fir, beech, larch), and the tops of the Apennines and remote plateaus ( 4.5 million acres), 
and of a few special places on which now and then even magnificent remnants of virgin forest may be foundlack of transportation having preserved them-most of the area is occupied by miserable brush forest, coppice or else open forest with scattered trees among a shrub undergrowth of thorns, hazel and chestnut (called macchia i. e., chapparal), so that most Italians have never seen a real forest. Nevertheless, Italy is by no means as treeless as this condition of forest would imply, for trees (poplar, ash, elm) are dotting the plains and slopes, planted for vine supports and boundaries, unshapely through pollarding and lopping the branches for firewood. Olive and chestnut groves on the hills (of the former 2 million acres, of the latter over 400,000 acres planted for the fruit), and 8.5 million acres in vineyards add to the wooded appearance of the country and to the wood supply. The annual product of firewood from these planted trees is estimated at 6 million cords.

On the sand dunes and near the seashore, especially in the marshes, the Maritime, the Aleppo pine, and the umbrella-shaped Pinus pinea, and picturesque Cypresses are sometimes found in small groves, while the calcareous hills in this region up to 1200 feet are studded with olives, cork and evergreen oak. Osier growing is here also quite extensively practiced. In the mountains, above the 2700 foot level, conifer forest, composed of Pinus silvestris and laricio, and Abies pectinata, has been reduced to less than 7 per cent. of the whole, mixed conifer and deciduous forest represents 4 per cent, the bulk being deciduous forest of oak (several species) and beech, with chestnut. Forty per cent. of this is in 


\section{Ownership.}

coppice (ceduo), 50 per cent. under selection system (a scelta) and 10 per cent under clearing system (ad alto fusto), although management hardly exists except in small groves.

That supply of workwood is insufficient for the needs of the population, and decreasing, is attested by the fact that the importations more than doubled in the decade from 1892 to 1903 to near 14 million dollars, 80 per cent. of which was saw material, while nearly 5 million dollars' worth was exported in the last named year, mostly cork, casks, thin boxboards, olive wood manufactures, and charcoal. No better picture of the forest conditions can be had than by a statement of the home production which in 1886 (last official data) was placed at 48 million cubic feet of workwood, valued at 3.4 million dollars, 223 million cubic feet firewood, valued at 4.1 million, 106 million cubic feet charcoal, worth 3.6 million, and by-products to the large amount of 6.4 million dollars, altogether a little less than 17.6 million dollars. Firewood and charcoal, which represent over 80 per cent. of the product, are, of course, furnished by coppice, and in addition by the pollarded material, almost the only fuel to be had.

The ownership of the forest area is for thegreater part private (53 per cent.) and communal (over 43 per cent.), the State owning less than 4 per cent. The State property being so small, supervision of communal and private forest has become the policy.

The State forest is of two classes, the alienable, under the Department of Finance, the larger part, about 375000 acres, and the inalienable, so declared by law of $18 \% 1$, of about 115,000 acres, which is under a forest 
administration in the Department of Agriculture; but of this about 20 per cent. is not forest, and even in 1896, some of this small area was sold. This area is to serve for demonstration of model management, and to supply government needs. Beech and oak with fir, pine and larch, mostly in timber forest, characterize this property, which is managed mostly in selection system. Curiously enough, in 1888, the difficulty of disposing advantageously of the old timber is complained of, due to lack of means of transportation. The personnel of the administration consists of a central bureau with one Inspector General, three Inspectors, and a Council. For each province, and in some cases for two or more provinces together, an Inspector with several Sub-inspectors and a number of guards or brigadieri are charged with the management of the State property and the enforcement of the forest laws.

2. Development of Forest Policy.

For centuries, since the fall of the Roman Empire ( $476 \cdot$ A. D.) until the end of the eighteenth century, Italy has been the victim of war and strife with neighbors or within its borders, being divided into numberless commonwealths, almost each city being independent. Hence no economic improvements could take place until, under the influences of the French Revolution, the regeneration period began. Not, however, until the seven or eight states which the Congress of Vienna (1815) had established were moulded into one united Italy under Victor Emmanuel, during the years 1859 to $18 \%$, could an effective reconstruction be inaugurated.

It is true that some of the republies in earlier times 
paid attention to their forest property. Notably in Venice, old forest ordinances* date back to $69 \%$, and, in 1453, a regular forest administration was instituted, especially to take care of the large forest area in Istria and Dalmatia, which fell into the hands of the Venetians about 1420 . A tolerably conservative management continued here until the beginning of the eighteenth century when, in consequence of political complications, supervision became lax, and devastation began which continued through the century, leaving to the new century, and finally to the Austrians, the legacy of the Karst (see p. 159.)

Florence too, managed to prevent the deforestation of the summit of her mountains until the beginning of the eighteenth century, and in other republics, kingdoms and duchies similar efforts at forest administration existed. Yet Genos, which in Strabo's time was the principal timber market of Italy, had by 1860 nearly all its mountain slopes denuded.

Before the general legislation for all Italy was enacted there were at least a dozen laws in operation in the various provinces; in Naples, the law of 1826; in Rome, of 1827 ; in Umbria, of 1805 ; in Bologna, of 1829 ; in Tuscany, of 1829; in Sardinia, of 1851 ; etc. If these had been heeded much better conditions would have been inherited by the new kingdom.

With the arrival of a national spirit, many schemes for the promotion of forestry were discussed. The academies of Florence, Milan, Modena, Palermo, and Pesaro offered premiums for reforesting of mountains, and called

\footnotetext{
* Brrenger, Saggio storico della legislacione Veneta forestale. 1863. An excellent source.
} 
for popular treatises on silviculture. A forestry journal came into being, furthering the propaganda. In 1860 a very well written account of "Present Conditions of Forestry and Production of Sulphur in Sicily," a collection of reports, was published by Shiro. In 1860 also, an investigation of forest conditions in each province was ordered by royal decree, and propositions for their improvement were called for, which led to legislative proposals, introduced in 1862, and legislation enacted in 1863.

The law of 1863 still treated each province independently: forest inspectors for each province, and for Naples an Inspector General, with district foresters and a large number of forest guards were appointed.

Another law, applicable only to certain parts of the Kingdom, was enacted in 1874, intended to check the progress of deforestation and prevent turning waste woodlands into pasture; these absolute forest soils were to be reforested within five years. The law remained a dead letter, yet it is still in force in part, with modifications enacted in 1886.

The final unification as far as legislative unity is concerned, was completed in $187 \%$, and in that year the first general forest law for all Italy was enacted.

This law, which has mainly in view the protective influence of forest cover as a factor in the public welfare, established provincial forest commissions, unpaid, who were to enact rules and regulations best adapted to their localities. The Board of Commissioners consisted of the prefect of the province, ex-officio president; an inspector of forests, the technical officer who administers the government property; an engineer appointed by the gov- 
ernor; and three members chosen by the provincial council ; in addition, each communal council was to send one member to take part in the deliberations of the board as far as his particular commune was interested.

By this law the country is divided into two sections vertically, namely the territory above and that below the limit of chestnut, the latter being that representing the farming country. To the former the restrictions of the law apply as a rule (terreni soggetti al vincolo forestale -ban forest), to the latter, as exception, namely where the removal of forest or brush cover might cause landslides, or affect stream flow or health conditions unfavorably. The chestnut limit naturally varies in different parts, but, generally speaking, lies between 1,800 and 2,000 feet elevation. The determination of these areas was to be made by the provincial forest committees, and it is significant to note that in these the forest administration did not have the majority.

The territory under restriction was in $188 \%$, after various revisions, established as comprising 7.5 million acres of forest and 2.5 million acres of brush and waste, leaving 2.5 of forest and somewhat over 2 million of brush and waste outside the working of the law; these latter are left entirely without restrictions, except as general police regulations apply.

The execution of the law and regulations is left to the State Forest Department with an organization of forest guards (some 3,000 in 1883), appointed by the prefect of the province with the adrice of the forestry commission, but acting under the State forest administration. Their pay was to come to the extent of twothirds from the communes, the other third from the provincial treasurer. 
If the regulations of the commissions had been observed to their full extent, all would have been well in time, but it is evident from subsequent legislative efforts that the execution of the laws was not what could be desired. Political exigencies required leniency in the application of the law. An interesting report on the results of the first quinquennium shows that during that time 170,000 acres were cleared, over 40,000 without permission, and by 1900 , it was estimated, deforestation had taken place on about 5 million acres.

Wrangling over the classification of the lands under ban has continued until the present, and local authorities have continued to favor private as against public interest, to withdraw lands from the operation, and to wink at disregard of the law. Moreover, rights of user to dead wood, pasturage (goats are by law excluded) and other privileges continued to prevent improvement, although several laws to effect their extinction had been passed.

The devastating floods of 1882 led to much agitation, and, upon a report of a special commission in 1886, the law of 1874 was revived, extending the term of obligatory reforestation in the endangered sections to ten years. By that time, out of 800,000 acres originally declared as requiring reforestation, not more than 40,000 acres had been planted, but the acreage involved had also been gradually scaled down by the forest committees to 240,000 acres. The report, on the other hand, found that the area needing reboisement was at least 500,000 acres, requiring an expenditure of 12 million dollars.

A revision and broadening of the law led to the gen- 
eral reboisement act of $1888,{ }^{*}$ which has in view the correction of torrents - one of the best laws of its kind in existence anywhere.

The principal features of the law are: obligatory reboisement of mountains and sand dunes according to plans, and under direction of the Department of Agriculture, the areas to be designated by the department, with approval or disapproval of the forest committees; contribution to the extent of two-fifths (finally raised to two-thirds) of the expense by the government; expropriation where owners do not consent, or fail to carry out the work as planned; right to reclaim property by payment of costs and interest, or else sale by government; right of the department to regulate and restrict pasture, but compensation to be paid to restricted owners; encouragement of co-operative planters' associations.

The execution of the law was not any stricter than before. In 1900, the Secretary of Agriculture reports that "the laws do not yet receive effective application." The difficulty of determining what is and what is not necessary to reforest, what is and what is not absolute forest soil made ostensibly the greatest trouble and occasioned delay, but financial incapacity, and political influences bidding for popularity are probably the main cause of the inefficiency.

Meanwhile the forest department tried from its scanty appropriation to promote reforestation by giving premiums and distributing from its 130 acres of nurseries during the years from 1867 to 1899 some 46

*For details see Fernow, in Garden and Forest, 1888, page 417. 
million plants and over 500 pounds of seed, and furnishing advice free of charge.

In 189\%, again a commission was instituted to formulate new legislation. This commission reported in 1902, declaring that all accessible forests were more or less devastated, accentuating the needs of water management, and proposing a more rigorous definition of ban forests, a strict supervision of communal forests, and the management of private properties under working plans by accredited foresters or else under direct control of the forest department, the foresters to be paid by the State, which is to recover from the owners.

It is to be noted that Italy is perhaps the only country where forest influence on health conditions was legally recognized, by the laws of $18 \% 7$ and 1888. The belief that deforestation of the maremnae, the marshy lowlands betweeen Pisa and Naples, had produced the malarial fever which is rampant here, led the Trappist monks of the cloister at Tre Fontane to make plantations of Eucalyptus $(84,000)$ beginning in $18 \%$, the State assisting by cessions of land for the purpose. A commission, appointed to investigate the results, in 1881 , threw doubt on the effectiveness of the plantation, finding the observed change in health conditions due to improvement of drainage; and lately the mosquito has been recognized as the main agency in propagating the fever. The new propositions did not any more recognize this claimed influence as a reason for public intervention. Nevertheless, to two Italians is due the credit of having found the true cause of salubriousness of forest air, namely in the absence of pathogenic bacteria. 
The first forest school was organized by Balestrieri, who had studied in Germany, at the Agricultural School near Turin about 1848, transferred to the Technical Institute in Turin in 1851 . This school continued until 1869, and from 1863 had been recognized by the State, assuring its graduates employment in State service. In 1869 the State established a forest school of its own (Institute Forestale) at Vallambrosa near Florence, with a three years' course (since 1886 four years) and, in 1900, eleven professors and 40 students. In spite of the State subvention of $\$ 8,500$, it appears that some peculiar economies are necessary, for owing to the absence of stoves the school is closed from Nov. 1 to March 1.

Besides the technical school at Vallambrosa, agricultural schools have chairs of forestry or arboriculture, as for instance the Royal school at Portici. As an educational feature, the introduction of Arbor Day, in 1900, should also be mentioned.

The existence of a forest school naturally produces a literature. While a considerable number of popular booklets attempt the education of the people, who are the owners of the forest, there is no absence of professional works. Among these should be mentioned $\mathrm{Di}$ Berenger's Selvicoltura, a very complete work, which also contains a brief history of forestry in the Orient, Greece and Italy. G. Carlos Siemoni's Manuele d'arte forestale (1864), and the earlier Scienza selvana by Tondi (1829) are encyclopedias of inferior quality.

In $1859 \mathrm{R}$. Maffei, a private forester, began to publish the Revista forestale del regno d'Italia, an annual review, for the purpose of popularizing forestry in Italy, 
afterwards changed into a monthly, which continued for some time under subventions from the government.

\section{SPAIN.}

"Poor Spain" is the expression which comes to the lips of everybody who contemplates the economic conditions of this once so powerful nation, almost the ruler of the world. Once, under the beneficent dominion of the Saracens, a paradise where, as a Roman author puts it, "Nil otiosum, nihil sterile in Hispania," it has become almost a desert through neglect, indolence, ignorance, false pride, lack of communal spirit, despotism of church, and misrule by corrupt bureaucracy.

With the exception of a narrow belt along the seashore, the whole of the Iberian peninsula is a vast high mesa, plateau or tableland, 1,500 to 3,000 feet above sea level, traversed by lofty mountain chains, or sierras, five or six in number, running parallel to each other, mainly in a westerly and southwesterly direction. These divide the plateau into as many plains, treeless, and for the most part, arid, exposed to cold blasts in winter, and burning up in summer. They are frequently subjected to severe droughts, which sometimes have lasted for months, bringing desolation to country and people. The

Revista de Montes, a semi-official journal, established in $187 \%$, is the best source. El Manuel de Legislacion y Administracion Forestal, by HILARIo Ruiz, and Novisima Legislacion Forestal, by DRL CAMPO, 1901, elaborate the complicated legislation up to 1894.

Dicionaro Hispano-Americano, 1898, contains an article (montes) on the administrative practice of the forest laws.

A Year in Spain, by a young American (Stidelz) 1829, gives an excellent account of physical conditions of the country and character of the people at that time.

Das moderne Geistesleben in Spanien, 1888, and Kulturgeschichtliche und Wirtschaftspolitische Betrachtungen, 1901, by Gustav DrRRKs, details character of institutions and people. 
rivers as they usually do in such countries similar to our arid plains, form cañons and arroyos, and, being uncertain in their water stages, none of them are navigable although hundreds of miles long, but useful for irrigation, on which agriculture relies. The great mineral wealth had made Spain the California of the Carthaginians and Romans, and it is still its most valuable resource.

Spain awakened to civilization through the visits of Phoenicians and Carthaginians followed by the Fomans. During the first centuries of the Christian era there occurred one of the several periods of extreme prosperity, when a supposed population of 40 million exploited the country. After the dark days of the Gothic domination, a second period of prosperity was attained for the portion which came under the sway of the industrious and intelligent Jloors or Saracens (711 to 1000 A. D.), who made the desert bloom, and whose irrigation works are still the mainstay of agriculture at present. Centuries of warfare and carnage to re-stablish Christian kingdoms still left the country rich, when in 1479 the several kingdoms were united into one under Ferdinand and Isabella, and the Moors were finally driven out altogether (1492). This kingdom persisted in the same form to the present time with only a short period as a republic (1873). Spain was among the first countries to have a constitution.

After the conquest of the Moors, and with the discovery of America, again a period of prosperity set in for the then 20 million people, but, through oppression by State and Church (Inquisition), which also led to the expulsion of the Jews and large emigration to 
America, the prosperity of the country was destroyed, the population reduced to 10 million in 1800 , and the conditions of character and government created which are the cause of its present desolation. Since the beginning of the century, the population has increased to near 18 million, but financial bankruptcy keeps the government inefficient and unable to accomplish reforms even if the people would let it have its way.

\section{Forest Conditions.}

It has been a matter of speculation whether Spain was, or was not, once heavily wooded (see page 11). In Roman times only the Province of La Manca is reported as being unforested, and in the 13th and 14th centuries extensive forest zones are still recorded. The character of the country at present, and the climate, both resembling so much our own arid plains, make it questionable to what extent the forest descended from the mountain ranges, which were undoubtedly well wooded.

At present the forest is mainly confined to the higher mountains. The best is to be found in the Pyrenees and their continuation, the Cantabrian mountains.

The area of actual forest (bosques) is not known with precision, since in the official figures mere potential forest, i. e., brush and waste land, is included (montes), and the area varies, i. e., diminishes through new clearings, of which the statistics do not keep account. Moreover, the statistics refer only to the "public forests," leaving out the statement of private forest areas, if any.

In 1859 , this area was reported as over 25 million 
acres or 20 per cent. of the land area (196,000 square miles); in 1885 the acreage had been reduced to about 17.5 million acres; and, in 1900 , to about 16 million, or 13 per cent. of the land area remained as public forest, and the total was estimated at somewhat over 20 million acres

The following peculiar classification, published in 18\%4, gives (in round figures) at once an insight into the meaning of montes, and the probable condition of the "public forest" area:

Acres.

State Reserves

865,000

Salable State Property

$4,550,000$

Public Institute Forest.

20,000

Communal Forest

$9,860,000$

Open Commons for Wood and Pasture

$1,880,000$

Common Pasture for Draft Animals

425,000

\section{Total}

$17,600,000$

An estimate of the actual forest (timber and coppice), does not exceed 12 million acres for a population of 17.5 million, or .7 acres per capita. Yet in spite of this evident lack of wood material, except for firewood or charcoal, the importations in 1903 did not exceed 13.5 million dollars, accentuating the absence of industrial development. The official statement of imports reports 6.5 million dollars more than the above figure, but this includes horses and cattle enumerated as forest products. These also figure in the exportations of 15 million dollars, which to the extent of onehalf consists of cork (some 5 million dollars from 630,000 acres) and tanbark, while chestnuts, filberts and esparto furnish the balance. 
In 1882 all the public forests produced from wood sales only $\$ 900,000$, but the value of the products taken by rights of user was estimated at nearly twice that amount.

The forest flora and its distribution is very similar to that of Italy, and is described fully in two volumes prepared by a special commission appointed for this purpose.

\section{Development of Forest Policy.}

Spain is noted for its comprehensive legislation without execution; it is also known that official reports are rarely trustworthy, so that what appears on paper is by no means always found in reality, hence all statements must be accepted with reservations.

The forest laws of Spain are somewhat similar to those of Italy, yet show less appreciation of the needs of technical forest culture. The value of forest resources and need of economy in their use was, indeed, recognized early. Recommendations for their conservative use are recorded from the 13 th century on. An ordinance of Pedro I, in 1351, imposed heavy fines upon forest destroyers. Ferdinand V, in 1496, expressed alarm at the progressing devastation, and, in 1518 we find a system of forest guards established, and even ordinances ordering reforestation of waste lands, which were again and again repeated during the century. In 1567 and 1582, notes of alarm at the continuing destruction prove that these ordinances had no effect. The same complaints and fears are expressed by the rulers during the 17th and 18th centuries, without any effective action. In 1748, Ferdinand VI placed all forests 
under government supervision, but in 1812 the Cortes of Cadiz, under the influence of the spirit of the French Revolution, rescinded these orders, and abolished all restrictions.

An awakening to the absolute necessity of action seems not to have arrived until about 1833, when a law was enacted and an ordinance issued, at great length defining the meaning of "montes," and institrting in the Corps of Civil Engineers a forest inspection. At the same time, a special school was to be established in Madrid. This last proposition does not seem to have materialized, for, in 1840, we find that several young men were sent to the forest school at Tharand (Germany).

No doubt, under the influence of these men on their return, backed by La Sociedad Economica of Madrid, a commission to formulate a forest law was instituted in 1846, and in the same year, carrying out ordinances of 1835 and 1843, a forest school was established at Villaviciosa de Odon, later (1869) transferred to the Escurial near Madrid. This school, under semi-military organization, first with a three-year, later a fouryear, course, and continually improved and enlarged in its curriculum (one Director and 13 professors in 1900), is the pride of the Spanish foresters, to all appearances deservedly. It was organized after German models by Bernardo della Torre Royas as first Director.

The creation of a forest department, Cuerpo de Montes, had to wait until 1853. This department, under the Minister of Public Works, is a close corporation, made up of the graduates of the school as Ingenieros de Montes, acceptance into which is based 
upon graduation and four years' service in the forest department as assistants, besides the performance of some meritorious work. The school stands in close relation to the department service.

The first work of the new administration was a general forest survey to ascertain conditions, and especially to determine which of the public forests, under the laws of 1855 and 1859, it was desirable to retain. The investigation showed that there was more forest (defined as in the above classification) than had been supposed, but that it was in even worse condition than had been known. The public forests, i. e., those owned by the State, the communities and public institutions, were divided into three classes according to the species by which formed, which was the easiest way of determining their location as regards altitude, and their public value; namely, the coniferous forest and deciduous oak and chestnut forests, which were declared inalienable; the forests of ash, alder, willow, etc., naturally located in the lower levels, therefore without interest to the state, which were declared salable; and an intermediate third class composed of cork oak and evergreen oak, whose status as to propriety of sale was left in doubt. In 1862 a revision of this classification left out this doubtful class, adding it and the forest areas of the first class which were not at least 250 acres in extent to the salable property. The first class, which was to be reserved, was found to comprise nearly 17 million acres (of which 1.2 million was owned by the State), while the salable property was found to be about half that area.

Ever since, a constant wrangle and commotion has been kept up regarding the classification, and repeated 
attempts, sometimes successful, have been made by one faction, usually led by the Minister of Finance, to reduce the public forest area (desamortizadoro), opposed by another faction under the lead of the forest administration, which was forced again and again to re-classify. In 1883, the alienable public forest area was by decree placed under the Minister of Finance, the inalienable part remaining under the Minister of Public Works (Fomento) ; very much the same as it was in the United States until recently. The public debt and immediate financial needs of the corporations gave the incentive for desiring the disposal of forest property, and, to satisfy this demand, it was ordered, in 1878 , that all receipts from the State property and 20 per cent. of the receipts from communal forests were to be applied towards the extinguishment of the debt.

The ups and downs in this struggle to keep the public forests intact were accentuated on the one hand by the pressing needs of taking care of the debt, on the other hand by drought and flood. Thus, in 1874, the sale in annual installments of over 4.5 million acres in the hands of the Minister of Finance was ordered, but the floods of the same year were so disastrous, (causing ? million dollars damage, 760 deaths, 28,000 homeless), being followed by successive droughts, that a reversion of sentiment was experienced, which led to the enactment of a reboisement law in $187 \%$. This law, with all sorts of unnecessary technical details, ordered the immediate reforestation of all waste land in the public forest, creating for that purpose a corps of 400 cultivators (capatacas de cultivos). To furnish the funds for this work the communities were to contribute 10 per cent. of 
the value of the forest products they sold or were entitled to. But funds were not forthcoming, and, by 1895 , under this law only 21,000 acres had been reforested (three-fourths by sowing).

The financial results of the management of the public forests, although the forest department probably did the best it could under the circumstances, have, indeed, not been reassuring. In 1861 , a deficit of $\$ 26,000$ was recorded; in $18 \% 0 \$ 600,000$ worth of material was sold, 1.3 million dollars worth given away, and $\$ 700,000$ worth destroyed. Altogether, by fire and theft, it was estimated that 15 per cent. of the consumption was lost. In 1885 this loss was estimated at 25 per cent., when the net income had attained to 15 cents per acre, or, on the 17.5 million acres to less than three million dollars.

When it is considered that the governors of provinces and their appointees, besides the village authorities, had also a hand in the administration, it is no wonder that the forest department was pretty nearly helpless. While under the law of 1863 the department was specially ordered to regulate the management of communal forests and to gauge the cut to the increment, the political elements in the administration, which appointed the forest guards, made the regulations mostly nugatory.

At last, in 1900, a new era seems to have arrived, a thorough reorganization was made, which lends hope for a better future. The technical administration was divorced from the political influence and placed under the newly created Minister of Agriculture. The machinery of the Cuerpo de Montes was remodeled. This consists now of one Chief Inspector-General, four Division Chiefs, ten Inspectors-General for field inspec- 
tion, 50 chief engineers or district managers, 185 assistants, and 342 foresters and guards, the latter now appointed by the department, instead of the Governors, and not all, as formerly, chosen from veteran soldiers.

In 1901 the Servicio Hidrological Forestal, the reboisement service, was also placed on a new footing, the country being divided into ten districts for this purpose, and an engineer placed in charge of each.

Since 1896, popular education is attempted through Arbor days, various associations fostering the idea, and, in 1904, La Fiesta del Arbol was made a national holiday, and premiums are distributed for plantations made on that day.

The Revista de Montes, a semi-official monthly journal, began its publication in $\mathbf{1 8 7 \%}$, and serves the purpose of propaganda, as well as the professional needs. A considerable book literature is also developed.

\section{PORTUGAL}

The small kingdom which occupies the west coast of the Iberian peninsula, with 36,000 square miles and 6 million people, is in many respects similar to Spain, except that a larger portion is fertile, being situated in the litoral region, the climate less excessive, and the people somewhat more enterprising. Not much more than one-half of the country, however, is utilized.

Three sections are recognized, the northern, which is mainly mountainous and contains extensive sand dunes, is the best wooded; the central, which is hilly and less well wooded, contains (in Estremadura and Beira) one of the most desolate regions of Europe and at the same 
time the best managed forest; the southern, the richest in farm lands, with semi-tropic climate and flora.

The entire forest area is only 640,000 acres or 3 per cent. of the land area. By including brushwood this may be increased to a million acres. Of the forest area 80 per cent. is coniferous ( $P$ inus pinaster and pinea), and 20 per cent. cork oak and other oaks, mixed with chestnut. An export of 5 million dollars worth of cork is the best developed industry, besides a considerable naval store production. The oak forest is largely used for hog raising.

The State property comprises only 80,000 acres, and this includes over 30,000 acres of sand dunes in process of recovery. The first attempt at management of this property dates from 1868; a regular organization, however, did not take place until 1872, when, under the Director-General of Commerce and Industries, a forest administrator with a technical staff of three division chiefs, corresponding to the three sections of country, and six forestmasters were installed.

The only really well managed forest, the pride of the Portuguese foresters, is the forest of Leiria in Estremadura, a planted pinery of about 25,000 acres, with naval store distilleries, impregnating works, and saw mills.

Besides attending to the management of the State forests, a committee composed of the administrator and some of the technical staff, were to examine the country and decide what parts needed reforestation. As a result of a very full report, in 1882, a reboisement law was enacted under which some of the sand dunes were fixed.

In 1903 a more thorough organization of this work 


\section{Portugal.}

took place, which, with liberal appropriations promises more rapid progress. It allows the expropriations of waste land declared as of public interest, if owners object to forced reforestation. Otherwise private forest property is without supervision.

The education of the technical staff is attended to in the School of Agriculture at Lisbon. 


\section{GREAT BRITAIN AND HER COLONIES.}

It is a remarkable fact that the nation which can boast of the most extensive forest department in one of her colonies, has at home not yet been able to come to an intelligent conception even, not to speak of application, of proper forest policy or forest economy.

One of the English authorities on the subject writes still in 1900: "With so much land of poor quality lying uncultivated in many parts of the British Isles, the apathy shown towards forestry in Britain is one of the things that it is impossible to understand."

If we should venture to seek for an explanation, we would find it in geographical and physical conditions, but still more in personal and political characteristics, historically developed, such as also in the United. States make progress of forestry slower than it would otherwise be.

Due to her insular position with which in part the development of her naval supremacy is connected,

Historical Inguiries concerning Forests and Forest Laws, by Pracival LEWIS, $18 \mathrm{x}$, gives a full account of the practices in the old ban forests.

English Forests and Forest Trees, 1853 , anonymous, gives an interesting account of the old 'forests' and their history.

Our Forests and Woodlands, by JOHN NiSBET, 1900, has a chapter on the historical development of torest laws.

WM. Schlich, Manual of Forestry, vol. I, $3^{\mathrm{d}}$ ed., rgo6, brings in convenient form an account of conditions in various parts of the British Empire.

Schwappach, Forstiche Zustände in England. Zeitschrift für Forst und Jagdwesen, 1903 , is an account of forest conditions from the pen of a practical observer.

B. RibBentrop, Forestry in India, rgoo. Also various report of the foreat departments of the various Britzsh Colonies. 
England can readily supply her needs by importations. Situated within the influence of the Gulf stream, the climate is much milder than her northern location would indicate, and is in no respect excessive. The topography is mostly gentle, except in Scotland and Wales, and the riverflow even all the year. Hence the absence of forestcover has not been felt in its physical influences.

Britons, Picts, Scots, Seandinavians, Anglo-Saxons and Normans are the elements which have amalgamated to make the English people. Through endless warfare and political struggle the three countries, England, Scotland and Ireland had by 1600 come under one ruler, although final legislative union with Scotland did not take place until 1707 , and with Ireland not until 1800 .

Theoretically, forming a constitutional monarchy, practically, an aristocracy with republican tendencies, the history of the islands has been a struggle, first to establish race supremacy, then to secure the ascendency of the nobility and landholders over the king and the commoners, in which the former have been more successful than the barons in other parts of Europe.

Politically, the Englishman is an individualist, jealous of his private interests and unwilling to submit to government interference for the public welfare. Hence, State forestry, which is finally the only solution of the forestry problem, appears objectionable. Commercial and industrial enterprise rather than economic development appeals to him; the practical issue of the day rather than demands of a future and systematic 
preparation for the same occupy his mind. He lacks, as Mr. Roseberry points out, scientific method, and hence is wasteful. Moreover, he is conservative and self-satisfied beyond any other nation, hence if all the wisdom of the world point new ways, he will still cling to his accustomed ones. In the matter of having commissions appointed to investigate and report, and leaving things to continue in unsatisfactory condition he reminds one of Spanish dilatoriness. These would appear to us the reasons for the difficulty which the would-be reformers experience in bringing about economic reforms.

\section{Forest Conditions.}

Cæsar's and Strabo's descriptions agree that Great Britain was a densely wooded country. The forest area seems to have been reduced much less through long-continued use, than through destruction by fire and pasture, and by subsequent formation of moors, so that it is now, excepting that of Portugal, the smallest of any European nation in proportion to total area, and, excepting that of Holland, in proportion to population.

Of the 121,380 square miles, which Great Britain and Ireland represent, less than 4 percent, or 3 million acres, (880,000 in Scotland, 303,000 in Ireland) are forested, one-fourteenth of an acre per capita; but there are over 12 million acres of heaths, moors and other waste lands capable of forest growth and of supplying in time the entire home demand, and another 12 million acres partly or doubtfully so, while the agricultural land in crops and pasture comprises 
about 48 million acres. Notably in Scotland, extensive heaths and moors of many hundred square miles, in the Northern Highlands and the Grampian mountains-well wooded in olden times, the woods having been eradicated supposedly for strategic reasonsare now without farms or forests, and are mainly used for shooting preserves. In the last thirty years, the land under tillage has continuously decreased, and now represents less than 25 percent of the whole land area, grasslands occupying 38 percent.

The agricultural land as well as the mountain and heath lands, are to the largest extent owned by large proprietors (in 1876, 11,000 persons owned 72 percent of the total area of the British Islands). With the exception of 67,000 acres of crownlands, the entire forest area is owned privately, there being no communal ownership, except that the municipality of London owns a forest area (Epping Forest) devoted to pleasure, and the Water Board of Liverpool has begun to plant some of its catchment basins.

Practically the entire wood supply is imported, and the rate of importation is rapidly increasing. While in 1864 it was 3.4 million tons, in $1892,7.8$ million tons worth 92 million dollars, in 1899, 10 million tons and 125 million dollars, in 1902 it had grown to 138 million dollars. This makes England the largest wood importer in the world, Germany coming next, and the amount paid to other countries exceeds the value of her pig iron output. Nearly 90 percent of the import is coniferous material, from Sweden, Russia and Canada. The home product, mostly oak ties, mineprops, etc., satisfies about one- 
sixth of the consumption. In addition to timber and lumber, over 10 million dollars of wood pulp, and 60 million dollars of by-products are imported.

Pine is the only native conifer of timber value, and oak is the most important native deciduous tree, found mostly in coppice or in old, overmature, straggling pasture woods. Compact larger forest areas are entirely absent, but there are many small plantations and parks. For, while Englishmen have not been foresters, they have been active treeplanters, and the mild climate has permitted the introduction of many exotics, especially American conifers. Most of these plantings have been for park and game purposes. The most noted forest plantations are found in Scotland, among them the larch plantations of the Duke of Athole (begun in 1728), of at one time over 10,000 acres, the ducal woodlands now covering over 20,000 acres; the pinery of 25,000 acres, belonging to the Countess of Sealfield, the best managed forest property, partly in natural regeneration, and others. But these plantations too are mostly widely spaced and trimmed, hence not producing timber of much value, so that timber of British production is usually ruled out by architects.

\section{Development of Forest Policy.}

The Saxons and Normans were primarily hunters, and this propensity to the chase has impressed itself upon their forest treatment into modern times.

The Teutonic Saxons undoubtedly brought with them the feudal and communal institutions of the 
Germans, under which territory for the king's special pleasure in the chase was set aside as 'forest', and this exclusive right and privilege was on other territory extended to the vassals, while the commoners were excluded from the exercise of hunting privileges on these grounds.

The Normans not only increased the lands under 'ban', but they increased also in a despotic manner the penalties and punishments for infraction of the forest laws, and enforced them more stringently than was done on the continent. The feudal system was developed to its utmost. Besides 'forests', in which the king alone had exclusive rights, and in which a code of special laws, administered under special courts, was applied, there were set aside 'chases', hunting reserves without the pale of the forest laws; 'parks', smaller, enclosed hunting grounds; and 'warrens', privileged by royal grant or prescription as preserves for small game. Whole villages were wiped out, or lived almost in bondage to satisfy this taste for sport. In the 'forests', of which in Elizabeth's time not less than 75 distinct ones were enumerated, withdrawing an immense area from free use, both 'vert' and 'venison',-wood and game,--belonged to the king; a host of officers,-stewards, verderers, foresters, regarders, agistors, woodwards,-exercised police duties, and oppressed and ground the people by extortions, while special courts,-'woodmote', 'swainmote', 'court of justice seat',--enforced the savage and cruel laws. The first of these laws was supposed to date from Canute the Great, in 1016, but was eventually found to be a forgery perpetrated by William I 
in order to lend historical color to his assertion of 'forest' rights.

A partial reduction of forests, and a modification of the cruelty and unreasonableness of the laws was obtained by the Charta de Foresta, in 1225, which formulated the laws into a code, and again by the Forest Ordinance of 1306. But not until 1483, under Edward IV, were the people living within 'forests', permitted to cut and sell timber, and to fence in for seven years, portions of the reserved territory. The last territory was 'afforested', i. e. withdrawn for purposes of the chase, under Henry VIII, but he had to secure the consent of the freeholders. The Long Parliament in 1641 stopped at least the extension of forests, and modified the application of the laws to a more reasonable degree.

The forest laws are still on the statutes, but have fallen into desuetude; the last 'forest court of justice seat' was held under Charles I. The 'forests' themselves have also almost entirely vanished, some being abolished as late as Queen Victoria's time, by act of parliament, but the last action under the 'forest laws' was had in 1862 when the Duke of Athole tried to establish his right as 'forester' for the crown.

In Scotland the same usages and laws existed, only very much less rigorously enforced, until in 1681 the extension of 'forests' was discontinued by parliamentary act.

It will be understood that the term forest did only distantly refer to woodland and that no economic policy had anything to do with the laws. Only incidentally was forestgrowth protected and preserved 
for the sake of the chase-the same medieval policy which animates at present the forest policy of the State of New York.

The woods outside the 'forests', which had mainly served for the raising of hogs, and for domestic needs, experienced at various times unusual reduction by fire. General Monk, among others, laid waste large areas on the Scottish borderland.

The first serious inroads occurred in Henry VIII's time, when he seized the church lands for his own use and turned them into cash. James I had fostered colonization schemes, especially in Ireland, which reduced the forest area, while Charles $I$, always in need of cash, alienated many of the crown forests, besides extorting money through the forest courts. On the other hand Henry VIII and James I had attempted to encourage planting for utility. During the Revolution, beginning in 1642, and during Cromwell's reign a licentious devastation of the confiscated or mortgaged noblemen's woods took place.

Finally, under Charles II, the needs for the royal navy forced attention to the reduction of wood supplies, and as a result of the agitation to encourage the growth of timber, a member of the newly formed Royal Society was deputed to prepare an essay, which, published in 1662, has become the classic work of English forest literature, namely John Evelyn's Sylva, or "A Discourse on Forest Trees," which has experienced eleven editions. It should, however, be mentioned that an earlier writer, whom Evelyn often quotes, Tuffer, before the reign of Henry VIII, in 1562, published his "Five Hundred Points of Husbandry," a 
versification in which treeplanting received attention. Ever since that time, periodically and spasmodically, the question of forestry has been agitated, without serious result.

From 1775 to 1781, the Society of Arts in London offered gold medals and prizes for treeplanting, and in the beginning of the 19th century a revival of arboricultural interest was experienced, perhaps as a result of an interesting report by the celebrated Admiral Nelson on the mismanagement of the forest of Dean, concern for naval timber giving the incentive, in which he recommended the planting of oak for investment.

At that time a Surveyor-General, with an insufficient force, was in charge of the crown forests. In 1809 the management was placed under a board of three Commissioners, one of whom being a member of parliament was changed with the administration. Under this management, graft became so rampant that, in 1848, a committee of the House of Commons was appointed, whose report revealed the most astonishing rottenness, placing a stigma on government management such as we uncover in the United States from time to time. A reorganization took place in 1851. At that time the royal forests and parks, reduced in extent to about 200,000 acres, showed a deficiency of $\$ 125,000$, mostly, to be sure, occasioned by the parks. There was then still a tribute of some 600 bucks to be delivered to various personages, as was the ancient usuge.

At present there are some 115,000 acres classed as royal forest, but only 57,000 acres are really forest 
consisting of more or less mismanaged woods, under the administration, not forest management of the Commissioners of Woods and Forests, with Deputy Surveyors in charge of the ranges. Although there are a few notable exceptions in the management, it is to be noted that the same stupid ignorance, which introduced the clause into the Constitution of the State of New York, was enacted into law in 1877 by the English Parliament, forbidding in the New Forest all cutting and planting. In 1900, there existed just one planting plan, made by a professional forester, namely, for a portion of the forest of Dean, while now only two other State properties and two or three private estates are managed under working plans.

In 1887, a Committee appointed to inquire into the administration of this property, expressed itself most dissatisfied, but a Committee of Parliament in 1890 whitewashed the administration and reported that the management was satisfactory.

These committees were also to recommend measures for the advancement of forestry. They laid in their recommendations the main stress upon education, but no action followed, and it can be said that the government has never done anything for the advancement of forestry in the home country, whatever it may have done for the dependencies. A Departmental Committee again reported in 1902 with all sorts of recommendations, which have remained unheeded.

The interests of forestry as far as the government is concerned are at present committed to the Board of Agriculture, an unwieldy body created in 1889, from which this Departmental Committee was appointed, 
and a strong movement is on foot, led by foresters returned from India, to commit the government to some action with reference to the waste lands, and towards providing for educational means.

The government, although various committees have recommended it, has remained callous in this respect also, except that in 1904 the Commissioners of Woods and Forests instituted a school (one instructor) in the Forest of Dean for the education of woodsmen and foremen.

As illustrative of the government's peculiar attitude to forest policy in general, w? may note a curious anachronism, namely the act of 1894 , which relieves railway companies from liability for damage from locomotive fires, if they can prove that they have exercised all care, although traction engines cannot offer this excuse.

The first attempt to secure educational facilities dates to 1884 when a chair of forestry was established in the Royal Engineering College at Cooper's Hill, an institution designed to prepare for service in India purely. Through private subscriptions another chair of forestry was instituted in 1887 at the University of Edinburgh, and, at present, several agricultural colleges, notably that of Cirencester and the Universities of Cambridge and Oxford, had made provisions for teaching the subject in a way, but outside of Cooper's Hill no adequate education in forestry was obtainable in Great Britain, until 1905.

In 1905 , the forest department in Cooper's Hill was transferred to Oxford, the three years' course-one year to be spent in the forests of Germany or other 
countries-being as before designed mainly for aspirants to the Indian forest service. The name of Dr. William Schlich, a German forester, and for some time the head of the Indian forest department now in charge of this school, is most prominently connected with the reform movement.

Altogether forest management and silvicultural practice are still nearly unknown in England, and, until within a few years, the useful idea of working plans had not yet penetrated the minds of owners of estates. This apathy is, no doubt, in part due to the fact that the government is in the hands of the nobility, who prefer to keep their "shooting ranges", and do not see even a financial advantage from turning them into forest as long as they can derive a rent of from 10 to 40 cents per acre for shooting privileges.

Private endeavor has been active through the two arboricultural societies, the Royal Scotch, founded in 1854, and the Royal English, beginning its labors in 1880. The transactions of these societies in annual or occasional volumes represent the current magazine literature on forestry, since the monthly Journal of Forestry and Estates Management, which began its career in London in 1877, transferred to Edinburgh in 1884 , ceased to exist in 1885. A Quarterly Journal of Forestry was begun by the English Society in 1907 .

Until within a short time the English professional book literature has been extremely meager, although $\mathbf{a}$ considerable propagandist, arboricultural, and general magazine literature exists. Schlich's Manual of Forestry, first in three volumes published from 1889 to 
1895, now in its third edition, enlarged to five volumes, is the most comprehensive publication. Another author deserving mention is John Nisbet, known by his Studies in Forestry (1894), who also engrafted continental silvicultural notions into later editions of James Brown's The Forester, an encyclopædic work of merit.

John Croumbie Brown's sixteen volumes on forests and forestry in various countries may be mentioned among the propagandist literature. The Arboricultural Societies mentioned also make a brave effort to advance professional development of forestry in their publications.

\section{INDIA.}

While so neglectful of its forest interests at home, Great Britain has developed in her possessions in the East Indies a far-seeing policy, and, under the lead of German influence, has established there one of the largest, if not most efficient, forest departments in the world.

Contrary to a frequently expressed idea that the conditions and problems of India are comparable to the conditions and problems of the United States, so that the example of Great Britain in India rather than that of any European country might serve us in the United States, the writer thinks that the very opposite is true. Not only are the natural conditions for the most part different, India being mainly tropical with an entirely different flora and different conditions of growth, but industrial, cultural, social and political conditions are also entirely different; all of which 
entails difference in methods of procedure. There are, to be sure, a few points of similarity: the large size of country under one government, and that in the hands of an English speaking race; the fact that the fire scourge, as with us, but from different reasons, is still the greatest problem; that there are arid regions and deserts (not over 10 percent), and irrigation problems and flood dangers to deal with; and finally the long delay in establishing a definite forest policy. Although this policy was inaugurated over 40 years ago, India has not yet, and will by the nature of things, not soon pass out of the first stage of development. which we may confidently expect to pass through much more rapidly, due to the conditions in which we resemble Europe more closely.

The greater part of India, namely 62 percent of the $1,766.000$ square miles, is under British administration, and is peopled by a subject race of nearly 240 million, without a voice in their government, which is carried on by a small handful of the conquerors (not 100,000 Englishmen are living in India), while the balance of nearly 600,000 square miles with 53 million people is divided among a large number of more or less independent native States, very different in their civilization from ours.

Industrially, the difference will appear from the statement that about 70 percent of the population is engaged in agricultural pursuits, hence there is no active wood market as with us, except for domestic purposes, and, as the woods, like those of most tropical forest, are mainly cabinet woods, even the export trade is insignificant, amounting to hardly 3 million 
dollars, while minor forest products (lac, cutch and gambier, myrobalan, caoutchouc, etc.) represent about 12 million dollars.

Climatically, as is to be expected, on such a large territory, great variation exists, which is increased by differences in altitude from the sea level to the tops of the Himalayas. The climate is, of course, largely tropical, with a rainfall which varies from the heaviest known, of 600 inches, to almost none at all.

Nevertheless, in spite of these differences from our conditions, much may be learned from Indian experience in the matter of organization, both to follow and to avoid, and the fact that this can be done without the need of a foreign language will be attractive to most Americans.

The British, like other nations, gained a foothold in India for trading purposes during the 17th century. This they extended during the 18th century, especially after they had attained the ascendancy by Clive's subjection, in 1757, of the great Mogul, one of the most powerful native princes. By conquest and amicable arrangement, the territory of British influence was gradually increased through the agency of the East India Company, until, in 1858, the British government in India was formally established by royal proclamation; and in 1877 it was declared an empire.

Native princes still control, under British influence and restrictions, over one-third of the country, or a territory of nearly 600,000 square miles, divided into 13 feudatory states. The total area under direct British control and government is $1,087,000$ square 
miles, of which 25 percent (280,000 square miles) is probably forested and waste, some 232,000 square miles or nearly 150 million acres of which are so far declared government property.

The British territory is divided into three presidencies (Madras, Bombay and Bengal) and nine provinces, each with a separate government under a governor, or commissioner, with a council, and all subject to control by the resident governor-general or viceroy and his council, and he in turn is responsible to the Secretary of State at home.

There is, however, little centralization of government functions, the provincial governments being to a large degree at least semi-autonomous, like the states in the United States, and considerable variation exists in the conduct of affairs. The difficulties in introducing something like a uniform forest policy were, indeed, not small, and much credit is due to the wisdom and tact of the three German foresters, who in succession filled the difficult position of head of the Imperial Forest Department and organized the serviceBrandis, Schlich and Ribbentrop.

\section{Forest Conditions.}

In the tropies rainfall conditions more than any other factor determine forest conditions. The rains of India depend on extraordinary sea winds, or "monsoons," and their distribution is regulated by the topography of land and relative position of any district with regard to the mountains and the vaporladen air currents. Thus excessive rainfall characterizes the coast line along the Arabian Sea to about 
latitude 20 degrees $\mathrm{N}$., and still more along the coast of Lower Burma, and to a lesser extent also the delta of the Ganges and the southern slopes of the Himalayas. A moderately humid climate, if gauged by annual rainfall, prevails over the plateau occupying the larger part of the peninsula and the lower Ganges valley, while a rainfall of less than 15 inches occurs over the arid regions of the lower Indus.

The rainfall, so unevenly distributed territorially, is moreover as unevenly distributed through the year. In most districts the principal rains are experienced in summer, the rainy season being followed by a long dry season. But on the Eastern coast the summer rains are slight, and the principal rainy season is delayed into October and November, while in Northern India and the Himalayas also winter rains occur, irregular and of short duration.

Even where a relatively large rainfall prevails, the climate is dry on account of the high temperature, hence some $30,000,000$ acres of the cultivated acreage (which comprises 225,000,000 acres in all) depend on irrigation, over half of this irrigated area lying in the tropical zone.

Roughly speaking, at least four climatic zones with many sub-types, may be recognized: the truly tropic, intensely hot and wet (over 75 inch rainfall), prevailing on the plains and tablelands of the lower half of the peninsula; the hot and dry (below 15 inch rainfall) climate of the Northwestern Indus plain and plateau; the moderately warm and dry to humid (30-75 inch rainfall) climate of the Ganges plain and central plateau; and the temperate to alpine, humid climate 
of the Himalaya mountains, with snow and ice in winter, and moderate heat in summer.

In keeping with this great diversity of climate, both as to temperature and humidity, there is a great variation in the character and development of the forest cover, and at least six types can be recognized, namely the evergreen forest, found along the West coast, in Burma, Andaman Islands, and the sub-Himalaya zone, which is composed of broadleaved species with a dense undergrowth of small trees and tangled lianas (vines), but few shrubs, as is characteristic of most tropical forest; the deciduous forest, mainly in the interior of Central India, with Sal, Teak and Ironwood as characteristic trees; the arid region forest, found in the Punjab, in Raiputana, and in Sindh, of varying composition, from the open shrub forests of the latter province, composed of acacias, tamarisk and mesquite, to the denser, more diversified, dry, low tree forest of the former; the alpine coniferous forest of the Himalayas and of the mountains of Afghanistan, Belutchistan, and Burma, composed of pine, deodar, juniper, with oak, walnut, boxwood, approaching our own forest types. In addition, there may be segregated the coast forest, of small extent, composed of trees which, like the mangrove, will bear salt water; the overflow forest along rivers; and river forests in the desert regions, of which latter large areas exist.

The natural differences in the forest cover are emphasized by the action of man, who for many centuries has waged war against the forest, clearing it permanently or temporarily for agricultural purposes, or else merely burning it over to improve grazing 
facilities or for purposes of the chase. Thus as we have seen, only about 24 or 25 percent of the entire area of India is covered by woodland, not over 20 percent being under cultivation, leaving about 55 percent either natural desert, waste, or grazing lands. The great forests of India are in Burma; extensive woods clothe the foothills of the Himalayas and are scattered in smaller bodies throughout the more humid portions of the country, while the dry northwestern territories are practically treeless wastes. Large areas of densely settled districts are so completely void of forest that millions of people regularly burn cow dung as fuel, while equally large districts are still impenetrable, wild woods, where, for want of market, it hardly pays to cut even the best of timbers.

The great mass of forests in India are stocked with hardwoods, which in these tropical countries are largely evergreens, or nearly so, although the large areas of dry forest are deciduous by seasons; only a small portion of the forest area is covered by conifers, both pine and cedar, these pine forests being generally restricted to higher altitudes. The hardwoods, most of which in India truly deserve this name, belong to a great variety of plant families, some of the most important being the Leguminosæ, Verbenaceæ, Dipterocarpeæ, Combretaceæ, Rubiaceæ, Ebenaceæ, Euphorbiaceæ, Myrtaceæ, and others, and a relatively small portion represented by Cupuliferæ and other families familiar to us. The most important, valuable species are Teak, Sal, and Deodar.

In the greater part of India the hardwood forest consists not of a few species, as with us, but is made up 
of a great variety of trees unlike in their habit, their growth, and their product, and if our hardwoods offer on this account considerable difficulties to profitable exploitation, the case is far more complicated in India, several thousand species entering into the composition. In addition to the large variety of timber trees there is a multitude of shrubs, twining and climbing plants, and in many forest districts also a growth of giant grasses (bamboos), attaining a height of 30 to 120 feet, which is ready to take possession of clearings. These bamboos, valuable as they are in many ways, prevent often for years the growth of any seedling trees, and thus form a serious obstacle to the regeneration of valuable timber. The growth of timber is generally quite rapid, although to attain commercial size, Teak requires usually a rotation of 150 years. But in spite of their rapid growth and the large areas now in forest capable of reforestation, India is not likely to-at least within reasonable time - raise more timber than it needs. In most parts of India the use of ordinary soft woods, such as pine, seems very restricted, for only durable woods, those resisting both fungi and insects (of which the white ants are specially destructive), can be employed in the more permanent structures, and are therefore acceptable in all Indian markets.

At present Teak is the most important hardwood timber, while the Deodar (a true cedar) is the most extensively used conifer. Teak occurs in all moist regions of India except the Himalayas, grows usually mixed with other kinds, single, or in clumps, is girdled two or three years before felling, is generally logged in 
a primitive way, commonly hewn in the woods and shipped-usually floated-as timber, round or hewn, and rarely sawn to size.

In 1903-4, the cut in the State forest area was $290,000,000$ cubic feet, timber and fuel, of which 20 percent was given to grantees or those holding rights of user free of charge, and less than 2 percent was exported. In addition, over 200 million bamboos and nearly two million dollars worth of by-products, such as lac, caoutchuc, cutch, gambier, myrobalans, were secured.

\section{Property Conditions.}

Prior to the British occupation, the native rulers, or rajas, laid claim to a certain proportion of the produce from all cultivators of the soil. They also reserved absolute right to the forests, and to all unseated or waste lands, although usually the people were allowed to supply their needs. The English government, by right of conquest, fell heir to these rights as well as to the properties, but, without care in asserting its rights, the unimpeded use of unguarded forest property led to the assertion of rights of user by the people, which were also sometimes granted. "Joint village" communities in some parts, i. e. settlements which occupy contiguous areas, claimed and occupied large areas of forest and waste as commons, and in general the original property rights of the government became uncertain.

The necessity of bringing order into this question led to various so-called settlements, by which the rights 
were defined, properties de-limited, and payment in kind changed into cash payments.

After attempts to regulate these matters by local rules, the first general Indian Fores Act, passed in 1865 , modified by the Forest Act of 1878 , laid down the basis upon which the rights of forest property were to be settled. These acts divide the forests into three classes, namely, those in which the right of the State is absolute; those in which the State has property rights, but which are burdened with preseriptive or granted rights of user; and those which are private property, but on which the State reserves the right to cut certain kinds of trees for government use, Teak, Sandalwood, and in some parts Deodar, these being considered "royal trees." The forest act being throughout applicable only at the choice and under the construction of the provincial governments. modified acts, applicable to different parts of the Empire, and different in details, were passed from time to time, and many different local rules were issued by the provincial governments, but all agree in fixing one definite policy, namely declaration or demarcation of government forests, after inquiry into all existing rights, and division of the declared government forests into reserves and protected forests, and unclassed, the former as permanent government reserves, the latter still open to change in ownership, and adjustment in rights of user, etc.

The absolute and relative areas of government property, therefore, are continuously changing. In 1900 the reserve forests comprised 81,400 square miles, or $8.6 \%$ of the total territory controlled by the British government; the protected forest 8800 square miles, 
and the demarcated but unclassified area swell the total to 117,000 square miles. These figures had, in 1904, changed to 91,567 for permanent reserves,, 865 for protected, and 131,269 for unclassed, showing the rapid change now taking place in the status of classification.

The name of B. H. Baden-Powell, at one time conservator of the Punjab and acting Inspector-General of Forests during 1872-4, is closely connected with placing this forest legislation on a sound basis. The object of this legislation was mainly to settle the question of ownership and rights, hence reserved forests are not necessarily set aside for forest purposes like the forest reservations in the United States, although ultimately this will probably be their condition.

Rights of user were under this legislation regulated or commuted. In some parts, even on the reserved forest areas, there are still retained rights to cut taungyas, i. e. to make partial clearings for temporary agricultural use, under the restriction of not destroying teak trees over 18 inches in diameter, and with the right of the cultivators to supply their domestic needs, under obligation to cut out fire traces, burning the brush, and instituting similar protective measures.

The title to the forest property having been secured, its permanent demarcation and a survey of the same were the next steps; the first having gradually been nearly accomplished, the latter being still far in arrears.

The area of private and communal forests is not precisely known, but, including waste land and lands of uncertain conditions, there are at least 500,000 square miles so owned, including those of feudatory rulers 
within the provinces. Of these, some 500 square miles or more of forest are leased to the government and under its control; and in some cases forest administrations are instituted by the rajas themselves.

In the Act of 1878 there was a clause calling for protection of private forest property against trespass and encroachment, but this remained a dead letter. By later legislation the government is entitled to exercise control over private forests and lands, if it appears necessary for the public weal, or if the treatment which such forests have received from their owners affect the public welfare or safety injuriously; but in such cases the owner can require the government to expropriate the land in question.

The forest act also provided that the government may assign to village communities from the reserved forest area so-called village forests, and make rules for their protection, use and management. How far this policy has been applied does not appear.

There are still areas the ownership of which is not settled, and rights which are still in doubt, the work of the so-called forest settlements still going on, several thousand square miles being annually changed in status, and several thousand dollars annually spent to quiet rights of user.

\section{Development of Forest Policy.}

Through the long history of India that preceded the arrival of the Mohamedans in the 10th and 12th centuries, it appears that the forest area was only slowly encroached upon by the Hindoo civilization. Even when the invaders, nomads by habit, drove many 
of the native race into the jungle to eke out a precarious life, owing to the remarkable recuperative powers of a tropical nature the impression made was not permanent. Although much forest growth was then destroyed, cleared or mutilated, changes took place only slowly.

It has been claimed, that in consequence of the destruction, which was incident to the nomadic life of the Mohamedans and the shifting agriculture of the aborigines, climatic changes were produced, but the proof for this assertion has remained questionable.

When in the 18th century the British entered India in rivalry with the French and other European nations, it was, of course, only for purposes of exploitation, and for a long time after the British had attained the ascendancy and had subjected most of the territory now ruled by them, not much concern was had about the forests; they furnished but small values, excepting in one particular, namely supplies of Teak for naval purposes. In the beginning of the 19th century the Government became concerned regarding these supplies, which under the rough exploitation threatened to become exhausted.

The first step towards securing some conservative management dates back to 1806, when Captain Watson was sent to India as Conservator of Forests, to look after the interests of the East India Company in this direction. His inability to compromise with those who had secured timber privileges led to his removal and an abandonment of the office, in 1823. Ineffective, sporadic efforts at administration by the provincial governments then followed. 
In 1839-40 the government of the Bombay Presidency stopped the cutting of Teak trees on government property. In $1843 \mathrm{M}$. Connolly, Collector of Malabar, in the Madras Presidency, began to plant Teak on a large scale at Nilambur. In 1847 Dr. Gibson was appointed Conservator of Forests in Bombay; from 1848 to 1856 Lieutenant (now General, C. S. I.) James Michael conducted the government timber operations in the Anamalai Teak forests (Madras), and made the first recorded attempts to protect Indian forests from injury by annual jungle fires.

In 1856 Dr. Hugh Cleghorn was appointed Conservator of Forests in Madras. He checked the destructive practice of temporary cultivation in the government forests of that Presidency, a measure, which at first was strongly opposed by the people, but his wellknown desire to promote native interests inspired the rulers of the country with confidence, and finally his measures were successful.

Various attempts at some kind of regulation of the exploitation by lumbermen were also made by the general government, after various examinations and reports, and in 1847 even a small and ineffective forest department was organized.

The annexation of the Province of Pegu in lower Burma in 1852 introduced a new complication, and proved the turning point in forestry matters. In this province, the right to cut Teak had been reserved by the native princes, and hence became a right of the crown, but private lumbermen began to cut this timber, and, after an investigation and report, it was decided to take definite steps to regulate at least the use of these valuable Teak forests. 
Lord Dalhousie, the then Governor-General, upon the basis of the report of the superintendent of forests at Pegu, Dr. McClelland, in 1855 laid down in statesmanlike manner an outline of a permanent forest policy for the government and introduced the first professional adviser.

In 1856 a German forester from Hesse, Dietrich Brandis (now Sir) was installed as superintendent of forests for Pegu with wide powers under contract for 10 years, at a liberal salary, and pension after retirement. The only possible check that could at first be applied was to force the lumbermen to make contracts, limit the diameter to which the exploitation was to be allowed, and mark the trees to be felled. This was done, naturally not without a large amount of friction.

The result of this experiment in forest conservancy, as the English are pleased to call it, was so satisfactory, that in 1862 it was decided to organize a forest department for all India; Brandis was entrusted with the organization, and in 1864 he was appointed head of the new department under the Secretary of Public Works with the title of Inspector-General, acting as adviser of the various provincial governments.

The forests of India during the next 20 years during which Brandis held office, were, province by province, brought under the regime of the Imperial Forest Department, although the provincial governments retain full and independent administrative power.

The first problem was to settle ownership conditions, which was done in the manner described before, by the act of 1865 , and by later acts.

The discontent which was created by this act came 
very near wrecking the whole enterprise, and much difference of opinion between the local and general governments existed, the government of Madras going so far as to declare the impossibility of establishing State property in view of the acknowledged rights of the villagers over waste lands. The general policy, however, finally prevailed, and an increasingly harmonious cooperation of the provincial governments has allowed the development of an efficient forest service.

Various provincial legislation was considered, passed and repealed, until in 1878 the Indian Forest Act VII settled the policy at least for the majority of the provinces, Madras and Burma and some minor districts still declining to extend its provisions to their forests. The Burma government enacted, however, similar legislation in 1881, and the Madras government in 1882, and, much later, the other outstanding governments followed (1886 to 1891), so that, while the detail of application varies not inconsiderably, the general policy regarding forest property of the State is the same throughout the empire. Whatever of uniformity exists had to be secured mainly by persuasive means.

The forest acts contain certain provisions regarding formation of village forests and control of private forest property, but no interference with private forest property has been attempted, aithough in some parts this is more important and larger than the State holdings. Most of the owners merely exploit their property, but some of the larger, more enlightened native princes have established forest administrations, imitating the example of the Imperial government. Those of Mysore and Kashmir and Hyderabad have placed this 
administration under an imperial forest officer, furloughed for this purpose, and derive handsome revenues; the Kashmir forests of about 2500 square miles yielding round $\$ 180,000$; those of Mysore, near 2000 square miles, over $\$ 330,000$, this largely derived from sales of sandal wood; those of the Nizam of Hyderabad, with 5200 square miles in reserves and 4400 in protected forests, deriving a revenue of $\$ 75,000$, seven times what it was ten years before.

\section{Forest Organization and Administration.}

The condition of affairs in the forest department can be briefly summarized as follows for the year 1904:

Total area under government control: 232,700 square miles, namely, Reserved, 91,567; Protected, 9,865; Unclassed, 131,269.

Officials: Higher grades, 312; Lower grades, 1,663; Guards, 8,533.

Rounded off Expenditures: $\$ 5,370,000$; Revenues, $\$ 8,720,000$; Net Proceeds, $\$ 3,320,000$ (40\% of gross).

In spite of the many difficulties, a poor market (no market at all for a large number of woods), wild, unsurveyed, and practically unknown woodlands, requiring unusual and costly methods of organization and protection, the forestry department has succeeded, without curtailing the timber output of India, in so regulating forest exploitation as to insure not only a permanence in the output, but also to improve the woodlands by favoring the valuable species, and thus preparing for an increase of output for the future, and at the same time has yielded the Government a steadily grow- 
ing revenue, which bids fair to rank before long among the important sources of income.

In 1865 the net revenue was only $\$ 360,000$, it had about doubled by 1875 , and more than trebled by 1885 , and since then has nearly trebled again.

While in the period of 1870 to 1874 the expense of the administration was still 70 per cent of the gross income, it has gradually been reduced to near 60 per cent.

At first the department and its operations as well as its finances were Imperial, the local governments having no control over its officers or over the revenue derived, but, in 1882, decentralization was effected, the local governments obtaining a direct interest in the revenues. As a result the financial interest overruled the conservative policy, and over-cutting was the consequence. In 1884, the general government recognized the need of a change. After some struggle the Imperial department was placed at least in charge of preparing the working plans, and pressure for their execution if not direct enforcement can be brought through appeal to the general government by the Inspector-General, which, however, has never been necessary to use.

The organization of the forest service passed through various stages, and the arrangement in the different provinces is even now not quite uniform.

The forest service then is peculiarly organized as regards division of responsibilities and relationships between the imperial and the provincial governments, the autonomy of the latter being jealously guarded. It is divided into the Imperial and the Provincial Service, the former consisting of the higher grade officials entirely recruited from England, the latter, the 
executive service, being in administrative functions independent of the former.

An Inspector-General, directly under the Secretary of Revenue and Agriculture, (for some time under the Home Department) is the head of the service, and acts as professional adviser both of the Imperial and the Provincial Governments. But this head of the service is shorn of most of its executive functions, all administrative matters being reserved to the provincial authorities.

The Inspector-General has charge only of the forest school administration, of forest surveys, and of the making of working plans, which latter after approval by the Provincial government, are in their execution inspected and critically supervised by him, but without power to enforce them, or to give direction directly to the Conservators in charge (at least in Madras and Burma). He also watches and reports on the progress of all forestry matters in the empire.

Peculiarities and great variety are also found in other official relations and in the appointing power, the general and provincial governments exercising certain rights in this respect.

The Controlling Staff (57 officers in 1869, now 200) under the Inspector-General, consists of Conservators, Deputy Conservators and Assistant Conservators. The Conservators, now 19, so far as they are not directly acting as assistants in the Inspector-General's office, are the heads of the provincial departments and conservatorships, and in that capacity directly subordinate to the local government, which in Madras and Bombay also has their appointment; each is in charge either of 
the entire forest business of the Province, or of a circle forming part of a Province and the administration unit in India. These are, therefore, the most influential and most responsible agents in introducing forestry practices. Conservatorships are divided into divisions, each in charge of a divisional forest officer, a member of either the Imperial or the Provincial Controlling Staff; but these have to acknowledge subordination to the Chief Civil officer, the Collector of the district in which they are located, in order to harmonize the financial and forestal interests.

About 80 per cent. of the Controlling Staff in the Imperial Service are appointed by the Secretary of State from graduates from the forest school at Cooper's Hill College, now Oxford, the remaining 20 per cent. from Englishmen in the provincial service, the members of which have passed through the Dehra Dun forest school and through the lower branches of the service. In addition to this Superior Staff, a Subordinate Staff of Extra Deputy Conservators and Extra Assistant Conservators forms the Provincial Service, which is to some extent recruited from the natives.

The districts are divided into ranges, for which an Executive Service is organized, of rangers (over 400), who are now selected from graduates of the forest school in Dehra Dun. Deputy rangers and foresters, a lower grade (some 1200), and guards, having their separate beats (over 8500), form the Protective Service, mostly recruited from the better class of natives. 


\section{Forest Treatment.}

With the irregular distribution of forests, the peculiarities of Indian government affairs and population, and the wild and difficult forest conditions themselves, it is but natural that the work thus far has been chiefly one of organization, survey, and protection.

In the protection against unlawful felling or timber stealing and grazing, the Government of India has shown itself fully equal to the occasion by a liberal policy of supplying villagers in proximity of the forests with fuel, building material, pasture, etc., at reduced prices or gratis. Over $\$ 1,000,000$ worth is thus disposed of annually, the incentive to timber stealing being thereby materially reduced. A reasonable and just permit system for grazing, where again the needs of the neighboring villagers are most carefully considered, not only brings the government a yearly revenue of nearly $\$ 800,000$ but enables the people to pasture about $2,000,000$ head of animals in the State forests without doing any material damage to tree growth. Of the reserved forest area, however, $38 \%$, and of the protected $20 \%$ were closed to grazing in 1902 , or only $17 \%$ of the total forest area.

The work of preventing and fighting fires can with the means available not be carried on over the entire forest area, of which large tracts are not even crossed by a footpath, and in a land where the regular firing of the woods has become the custom of the centuries, and where, in addition, intensely hot and dry weather, together with a most luxuriant growth of giant grasses, render these jungle fires practically unmanageable. Each year, however, additional territory is brought 
under protection. In 1902 nearly 37,000 square miles, or nearly $40 \%$ of the area in reserve, but only $12 \%$ of the total government forest area, were under protection at a cost of $\$ 4.00$ per square mile or less than one cent per acre, half of what it was 10 years before, and over 2 per cent. of the gross revenue. Nearly 5,000 fires occurred, to be sure, which burnt over 3,000,000 acres, that is to say over 90 per cent. of the area the protection was effective. For nearly half the fires the cause remains unknown. Danger from fire has, however, become less in protected areas because of the changes in herbage and moisture conditions. Yet it costs still about two per cent. of the gross revenue to protect the area, and the figures just cited show that this expenditure is only partially effective.

The first successful attempts to deal with forest fires were made in 1864 by Major (now Colonel) G. F. Pearson, who was then Conservator of Forests in the Central Provinces, and who devised a system of cleared fire lines or "fire traces," surrounding the areas to be protected, which were cut and burned over early in the season, a system now in vogue in all India. In the jungle forests the traces must be broad; the grass often taller than an elephant must be cut and burned before the grass on either side is dry enough to burn.

This protection forms the most important duty of the forest officials, a trying one as it has to be carried on during the hot season.

A separate branch of the forest service carries on the work of surveying and mapping the forest area instead of the regular Survey of India, with the result of cheapening the cost. Some 60,000 square miles have been 
mapped on the scale of 4 inch to the mile, the standard. some smaller areas on smaller scale, at the rate of $\$ 25$ per square mile.

Silviculture. Silvicultural practices are naturally but little developed. Protection against fire, grazing, overcutting has been the first requisite. The unregulated selection system with a diameter limit, which Brandis introduced, still prevails mostly, although beginnings of a compartment and group system in converting miscarried selection forest of Deodar, Pine and Sal have been made, or rather of an improved selection method, which seeks to secure reproduction in groups. Clearcutting with seed trees held over is practised in the coniferous mountain forest. Coppice and coppice with standards (reserves of sprouts) is a natural condition over large areas, especially with Teak and Sal. Even improvement cuttings or sowing on barren hillsides, with remarkable success, are not absent.

The attempts at securing reproduction, especially in the truly tropic forests have often miscarried, inferior species filling the openings. Girdling of inferior species to favor the better classes has hardly had the desired result. In the deciduous forest the same difficulty of undesirable aftergrowth is experienced, deteriorating the composition, except in the case of the gregarious Sal tree (Shorea robusta), the treatment of which for reproduction has, after many failures, been well established. Other gregarious species also can be satisfactorily reproduced. The culled and burned-over forests, of which there are many, are re-habilitated in a manner by merely removing the old overmature and defective timber, with comparative success. 
In some parts of the large gregarious bamboos are a serious obstacle to reproduction. The only chance for reproduction exists when they flower and die. Killing the bamboos by cutting the annual shoots proved a failure, but burning over the whole area and sowing seems to be followed by success.

In other parts, as in the large Teak forests of Burma, as well as of other provinces, the useless kinds of trees are girdled, huge climbers are cut off, and a steady war is waged against all species detrimental to teak regeneration with satisfactory results. With Teak even planting on a larger scale is resorted to, especially by means of taungyas, i. e. plantations, where the native is allowed to burn down a piece of woods, use it for a few years as field (though it is never really cleared) on condition of planting it with teak, being paid a certain sum for every hundred trees found in a thrifty condition at the time of giving up his land. Similarly, the department has expended large sums in attempting to establish forests in parts of the arid region of Beluchistan, and on the whole during $1894-95$ about $\$ 150,000$ were expended on cultural operations, which up to that time involved about 76,000 acres of regular plantations and 36,000 acres taunyyas (mostly teak), making a total of 112,000 acres, besides numerous large areas where the work consisted merely in aiding natural reproduction.

But in 1902 the plantations seem to have been reduced to 63,000 acres, (probably through failures), the taungyas however increased to 64,000 acres, and the budget for plantings and other cultural measures formed nearly two per cent. of the gross revenues. 
We see then, that though the forests of India are now, and will continue for some time to be little more than wild woods with some protection and a reasonable system of exploitation in place of a mere robbing or culling system, yet the work of actual improvement steadily increases in amount and perfection.

In disposing of its timber the Government of India employs various methods. In some of the forests districts the people pay merely a small tax and get out of the woods what and as much as they need. In other cases the logger pays for what he removes, the amount he fells being neither limited in quantity nor quality. The prevalent systems, however, are the permit system, where a permit is issued indicating the amount to be cut and the price to be paid for the same, and the contract system, where the work is more or less under the control of government officers and the material remains government property until paid for. To a limited extent the governments carry on their own timber exploitation.

Working Plans. Only a relatively small part of the total forest area, each year, however, increasing, is as yet worked under plans. In 1885, only 109 square miles, in 1899, 20,000 square miles, and in 1903, nearly 30,000 square miles, about 13 per cent. of the total, or 30 per cent. of the reserved area, were operated under working plans.

Only gradually was the character of these plans brought into practical form, and their execution, in spirit at least, enforced, the Conservators having the right to deviate from the plans. 
A map, prepared by the survey branch naturally forms the basis of the plan. The form of the plan is prescribed by the provincial regulations, and the preparation is also carried on by the provincial service under advice and supervsion of the imperial department. The "strip valuation survey", which Brandis introduced, covering sometimes as much as 30 per cent. of the area, is employed in determining number of trees and sizes, growing stock and cut, modeled after the European practice, except that little, perhaps too little, money is spent on their elaboration, especially on determining the proper amount of cut. That the cut is controlled at all is the most important result.

\section{Education and Literature.}

In 1866, Sir Dietrich Brandis selected as assistants two young men who had been trained in the Forest Schools of Germany-in turn his successors-and at the same time arrangements were made for the training of young Englishmen in the forest schools of France and Germany. At the end of 1875 the professional education was entirely transferred to Nancy. The present force of Conservators is composed largely of these men. For some reason, the training of men in Germany and France became unpopular, and this objection finally led, in 1884, to the establishment of a chair of forestry at Cooper's Hill College for Engineering in England. At first, the course of study extended over 26 months, during 22 of which the candidates prosecuted their studies at the college; the remaining four months being spent under suitable supervision in selected British and Continental forests. 
In 1905, this department was transferred to Oxford University and the course extended to three years, one year to be spent in continental forests.

Mr. Brandis early saw also the necessity of providing the means of giving the natives of India some sort of technical education in forestry. The first step in this direction was to place natives, selected ones, under one or two officers of the Imperial Service who were deemed fit to instruct them, and in this way a few good men were turned out. Another experiment after the German pattern was made by apprenticing likely young men under some forester for a year or two and then sending them to an engineering school for theoretical instruction. This was also a failure. After much hard work the Indian forest school at Dehra Dun was established in 1878, the forests between the Jumna and the Ganges rivers were set aside as training grounds, formed into a special Forest Circle and placed under the control of the director of the school. These forests have been subjected to regular systems of management, based on European experience, and excellent results have been obtained. The first course of systematic theoretical instruction was opened on the 1st of July, 1881. In 1884 the school was made an imperial institution by the Government of India, and the InspectorGeneral of Forests was charged with its supervision, under a Board of Control, consisting of the InspectorGeneral, the Director, and three Conservators, with the Assistant Inspector-General as secretary. This board meets once a year at Dehra, conducts the examinations, and looks into all of the workings of the School very . carefully. There are two courses-one in which the 
teaching is given in English for rangers, the other in which the instruction is given in the vernacular for foresters. Courses extend over $23 \frac{1}{2}$ months. The training is not high but it seems to answer the purpose very well. The Dehra Dun forest school provides the rangers for the provinces. The Bombay Presidency had for some time their own forest school in connection with the Engineering College at Poona, but this is now abandoned.

Forest Experiments and Investigations have never been systematically instituted, being left to individual initiative, but lately provision has been made in connection with the Dehra Dun school.

Besides a monthly journal, the Indian Forester which came into existence in $\mathbf{1 8 7 5}$ by Schlich's initiative, and the annual reports of the various conservators and of the Inspector-General, a small book literature has developed within the last ten or fifteen years.

Descriptive volumes of note are J. S. Gamble's Manual of Indian Timbers, new edition, 1902; Trees, Shrubs and Woody Climbers of Bombay Presidency by W. A. Talbot, 1902; Ribbentrop's Forestry in British India, 1900, and the earlier publication of H. R. Morgan, Forestry in Southern India; Brandis' Indian Forestry and Distribution of Forests in India. Of professional interest are E. E. Fernandez Manual of Indian Silviculture, unfortunately out of print; the same author's Forest Industries; D'Arcy's Manual on Forest Working Plans; C. C. Roger's Manual of Forest Engineering in India, and B. H. Baden-Powell, Forest Law.

The influence of the development of the Indian Forest Service on the forest policy of other British colonies 
and of the home country has been considerable, and is growing, Indian forest officers being detailed to assist in developing forest policies in these other parts of the British empire.

\section{CANADA.}

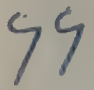

The largest single colony of Great Britain and the most important as regards forest supplies, both as to quantity and character, Canada has been for a long time supplying the mother country with a large proportion of her imports. Newfoundland is politically outside of the Dominion of Canada, but geographically the name Canada is used to designate the whole of the Northern portion of the continent.

Although in size larger than the United States, its land area being estimated at over $3,600,000$ square miles, Canada has so far attained only one-fifteenth of the population of her neighbor, namely less than 6 million. Much of her territory is still unknown, and will remain for a long time unavailable for civilization owing to its inhospitable climate. Indeed, as yet not one-third of its territory may be considered opened up to civilization, and hardly more than 100,000 square miles can be said to be occupied, one-half improved in farms, and two-thirds of this in crops.

Report on the Forest Wealth of Canada, by the Statistician of the Department of Agriculture, 1895.

Reports of Crown Lands Departments, of Bureau of Forestry of Ontario, and of Forestry Branch of the Dominion.

DefeBaugh's History of the Lumber Industry of America, Vol. I, 1906, brings together much information on this phase of the subject.

Hough's Report on Forestry, Vol. II, 1880, has a compilation of earlier statistics, 
Much of the northern country remains unorganized and the vast North West Territory $(2,665,000$ square miles) between Hudson's Bay and the Rocky Mountains, as well as Labrador, are for the most part uninhabited except by Indians and a few military and trading posts.

The central interior region, dotted with lakes and intricate river systems, is a continuation of the forestless, arid and subarid, plains and prairies of the country West of the Mississippi River, toward the north changing by steps into lowlands studded with open treegrowth, and barren tundra frozen all the year, a million square miles answering to this last description. The Pacific Slope is a rough and lofty mountain country, the extension of the Rockies and Coast Ranges, with humid and temperate climate, more or less heavily wooded, about 600,000 square miles, with the Fraziter River in the South forming the most important drainage.

The Atlantic portion, south of the plateau-like, bare, or scantily wooded Hudson Bay and Labrador country, is formed by the slopes of the watersheds of the Great Lakes and of their mighty outlet, the St. Lawrence River and its Gulf; the slopes rising gradually northward to the low range of the Height of Land, a plateau with low hills, not over 1500 feet elevation, which cuts it off from the northern country and forms the limit of commercial forest. This region, the bulk of the provinces of Ontario and Quebec-a belt of not exceeding 300 miles in width and about 1500 miles in length, altogether 300,000 square miles-with 93,000 square miles of the maritime provinces, around 250 
million acres in all, represents, outside of British Columbia, the true forest region of Canada, and at the same time the center of Canadian civilization.

Although the Cabot brothers discovered Cape Breton and Labrador in 1497 and 1500, the first settlement of Canadian territory was not made until 1541 by French colonists, after the first Captain-General of Canada, Jaques Cartier, the discoverer and explorer of the St. Lawrence (in 1534), had taken possession of the country for Francis I; but not much progress was made until Champlain's arrival in the first years of the next century. Quebec was founded as early as 1608, and Montreal in 1611, but Ottawa dates its first beginnings not farther back than 1800 .

The northern country around Hudson's Bay was, under the name of Rupert's Land (after Prince Rupert, the head of the enterprise), undefined in limits, granted by Charles II, in 1670, to the Hudson's Bay Company, a powerful fur-trading corporation which had not only a commercial monopoly but, except for occasional interference by the French, held absolute governmental sway over the country through 200 years, their jurisdiction at one time extending to the Pacific Coast.

Friction and warfare with the English resulted in the latter acquiring by the treaty of Utrecht in 1713 , Newfoundland and settling their rights on 'Hudson's Bay. The final conquest of "New France" by the English ended French rule in 1763, but the French colonists remained peacefully, and their descendants form to-day, at least in Quebec, the predominating 
influence. Indeed, in 1774, by the so-called Quebec Act, the first permanent system of self government was established much on the lines of the French feudal system, and the French civil law was retained.

At first, under English rule, the territory, then including the States of Ohio, Indiana, Illinois, Michigan, Wisconsin and Minnesota, formed one colony, but after the war of the Revolution, in 1791, it was divided into two separately governed provinces, Upper and Lower, or West and East Canada. They were re-united in 1840 , and continued so until 1867 when the so-called Union Act effected the present organization of the Dominion of Canada, a federal union, comprising only the provinces of Ontario, Quebec, New Brunswick and Nova Scotia. After various combinations and subdivisions all of the British Possessions in North America, except Newfoundland and its dependencies in Labrador, came in, and in 1882 the union was completed with the then seven provinces (those mentioned with Prince Edward Island, Manitoba and British Columbia) and all the organized and unorganized territory. In the same year four territories, Assiniboia, Saskatchewan, Alberta and Athabasca, in 1895 the territory of Ungava in Labrador, and in 1898 that of Yukon were organized, with a view of their eventual elevation into provinces, the relationships of the federation being quite similar to that of the states and territories in the United States.

The government, although practically much like a republic and largely independent of the home country, is theoretically a limited monarchy, the king being represented by a Governor-General, appointed by the 
king, and a privy council selected by the governor. The latter also appoints (now 81) senators for life to form the upper house of the Parliament or legislative body, while the lower House of Commons is elected by the people. Besides this imperial government, each province has its own separate government with a lieutenant-governor, appointed by the GovernorGeneral, and an elected legislature; this automony being somewhat similar to that of the states of the United States and the division of functions between federal and provincial governments being also similar. Although the home government retains the veto power, the supreme jurisdiction and various other powers, and although apparently, by the appointment of officials, its influence is guarded, practically the party management as exercised in Great Britain prevails, and independence from imperial influence is continually increasing. The closer relation, however, which comes from the appointment of the governors, who with their councils have quite extended powers in executive direction, renders the possibility of development of uniform policies much easier than in the States. In regard to the crownlands, including forests, this division as well as this relationship becomes important. Each provincial government administers the crownlands within its boundaries in its own way, yet on similar lines, while the Dominion government controls only the lands located outside of the provinces. These latter lands were mostly acquired by purchase from the Hudson's Bay Company, the Company relinquishing its territorial rights in 1868 , and the transfer being completed in 1870 upon payment of $£ 300,000$. 


\section{Forest Conditione.}

The forest area has at various times and by various authorities been roughly estimated, the latest estimate being one and a quarter million square miles, which would make the forest percent about 34 . But this includes the open woodlands of the northern territory and of the prairies, which, while of great importance to the local settlers, are for the most part probably or surely not of commercial value. Commercially valuable forests, actually or prospectively, are found only in British Columbia and in the old provinces, the two forest regions separated, just as in the United States, by the forestless region, except that north of the prairie region a continuous belt of open woodland extends to near the mouth of the Mackenzie River. A careful examination of the sources of inform 35 is has led the writer to the conchision that less than 000 square miles or round million acres would cover fully the commercially valuable forest land, two-fifths of which is to be found in British Columbia.

Indeed, although we are accustomed to look upon Canadbas a great forest country, it really possesses about percent less commercial forest area than the United States. It will be understood that all such $\checkmark$ statistics are merely rough estimates, the data being slim, and eked out by conjectures based on geographical conditions which predicate the character of the country. Most unreasonable speculations and calculations* as to amount of timber standing and value have been made on impossible assumptions.

* As an instance, one statistician by mere mathematical figuring, namely, deducting the known crop and pasture area from the total land area would make the forest area of Quebec over 209 million acres. This includes the country north of 
While by the change of standards and by local needs forest areas may become commercially valuable which were not so considered before, and thereby the above figures may be eventually increased, from the standpoint of valuable lumber supply for the world trade, the above named area may be assumed to set the limit.

A computation based on slender information has placed the country with open woodlands in the central region as exceeding 280,000 square miles. The Superintendent of Forestry estimates that 150,000 square miles of this area might contain nearly 200 billion feet merchantable timber.

The southeastern territory south of the Height of Land was originally all densely wooded. From it a farm area of round 25 million acres has been cut out, less than 7 percent of the land area included. Especially the south-western half of Ontario, between the Great Lakes, which contains the most fertile land, is densely settled, as also the shores of the St. Lawrence. A large part of the remaining forest area is cut over and culled, especially for pine; the amount of White Pine remaining according to estimates made in 1895 would now be less than 20 billion feet.

The Statistician of the Dominion in his report made in that year comes to the conclusion that "the first

the Height of Land, of 163 million acres, which by another mathematical calculation is made to be able to furnish over 65 billion feet of lumber, besides over 600 million cords of pulp and 370 million railroad ties; but under present conditions, owing to topography and character of the timber it cannot be utilized and its commercial value is altogether problematical. This calculation would leave as really or potentially available forest land 16 million acres in addition to over 5 million on farms. It is claimed that this forest area may still produce some 110 billion feet of coniferous and 1.5 billlon feet of hardwoods, or 2500 feet to the acre. 
quality pine has nearly disappeared" and that "we are within measurable distance of the time when, with the exception of spruce as to wood, and of British Columbia as to Provinces, Canada shall cease to be a wood exporting country."

The composition in general is the same as that of the northern forest in the United States: hardwoods (birch, maple and elm prevailing) with conifers mixed, the latter, especially spruce, becoming occasionally pure. The nearly pure hardwood forest of the southern Ontario peninsula has been almost entirely supplanted by farms, and here, even for domestic fuel, coal, imported from the United States, is largely substituted for wood. Although White Pine, the most important staple is found in all parts of this forest region, the best and largest supplies are now confined to the region north of Georgian Bay. Unopened spruce and fir lands still abound especially in Quebec on the Gaspé peninsula. Spruce forms also the largest share in the composition of the New Brunswick, Nova Scotia and Newfoundland forest, the pine in the first two provinces having practically been cut out. Extensive, almost pure balsam fir forest, fit for pulp wood, still covers the plateau of Cape Breton, while Prince Edward's Island is to the extent of 60 percent cleared for agricultural use.

Much of this Eastern forest area is not only culled of its best timber, but burnt over, and thereby deteriorated in its composition.

North of the Height of Land, in Ungava and westward, spruce continues to timber line, but, outside of narrow belts following the river valleys, only in open 
stand, branchy, and stunted, hardly fit even for pulp, for the most part with birch and aspen intermixed. This open spruce forest continues more or less to the northern tundra and across the continent to within a few miles of the mouth of the Mackenzie River and the Arctic Ocean, the White Spruce being the most northern species. In the interior northern prairie belt groves of aspen, dense and well developed, skirt the water courses and form an important wood supply.

If much of the forest area in the settled provinces is burnt over and damaged by forest fire, much more extensive destruction is wrought in this northern forest by fires sweeping annually over millions of acres unchecked, many of them started by lightning.

Among the large notable forest fires the great Miramichi fire in New Brunswick in 1825 destroyed more than 6,000 square miles in a few hours. In 1880 the loss by forest fires in the Ottawa valley alone was still estimated at $\$ 5,000,000$ annually.

The forests of British Columbia partake of the character of the Pacific forest of the United States, the Coast Range with conifers of magnificent development, Douglas Fir, Giant Arborvitæ, Hemlock, Bull Pine and a few others, the Rocky Mountain range also of coniferous growth, but of inferior character, large areas being covered with Alpine Fir (Abies lasiocarpa) and Lodgepole Pine, important as soilcover and for local use in the mining districts, but lacking in commercial value.

The river systems of Eastern Canada, with the mighty St. Lawrence permitting sea-going vessels to come up to Montreal, have been most potent factors 
in the development of the lumber industry and export trade, without the need of railroads. Yet although, as a consequence this trade was early developed to a relatively large figure, it has not grown at as rapid a rate as might have been expected, and to-day with an export of less than 40 million dollars is considerably below that of the United States.

The small export trade of earlier times, having been stimulated by exempting Canadian timber from paying duties in the home country, or at least allowing it a preferential tariff, had by 1820 grown to 15 million cubic feet, all squared timber, and sent to England. In 1830 it had crept up only to 20 million cubic feet, but by 1850 it amounted to over 50 million cubic feet, twofifths of which was sawed material, the 2632 mills being reported by the Census (1851) as having cut 776 million feet B. M. By 1868, when the Dominion was formed, the total export of forest products had advanced in value to $\$ 18$ million; the next decade, with a climax year in 1873 of $\$ 26$ million, saw an increase to $\$ 20$ million, the proportion of sawn material being nearly three times that of hewn wood, and the entire cut of Ontario going to the United States. At that time it was computed that the waste of value in shipping square timber amounted for the province of Ontario alone still to over $\$ 350,000$ annually. At present sawed lumber, deals, boards, planks, etc., forms 70 percent of the total export.

In the last 20 years a steady increase in exports at an average rate of about 3 percent per annum is noted, the total in 1903 culminating at $\$ 40$ million, and in the following year sinking to 37.6 million. But, while 
exports of forest products thus increased absolutely, relatively to other exports they have considerably declined, i. e. the lumber industry has not grown proportionally to other developments, for while in 1868 forest products formed 34 percent of the total export, in 1904 they represented only about half that figure.

The same conclusion, namely that the lumber business has not increased rapidly in the last 25 years, may be derived from the report of the Decennial Census. While for 1890 the total cut amounted to over 5 billion feet and its value to nearly $\$ 80$ million, in 1900 the cut fell below 4 billion and its value to $\$ 53$ million.

$\checkmark$ A measure of the depletion of the great staple White Pine is found in the statement that from 1865 to 1893 the average size of pieces decreased by one-quarter to one-third, and that in 1863 over 23 million cubic feet were exported from Quebec as against 1.5 million feet in 1904, while the price had more than quadrupled in that period. Spruce has here taken the place of pine, and Ontario is now the main producer of pine. Spruce, and especially pulpwood, forms an ever increasing item in cut and export, export of pulpwood having increased sevenfold in the last decade, to nearly $\$ 2$ million, and of woodpulp to over $\$ 3$ million.

A notable economic improvement has taken place during the last ten or fifteen years in that the proportion of raw materials exported, especially logs and square timber, has decreased in favor of manufactures.

While originally the home country took the bulk of exports of forest products, the cut of Ontario has been always, duty or no duty, sent almost entirely to the United States. In the last six or eight years, the ex- 
port to the United States has been doubled, amounting now to about half of the total export, and as we return of our own forest products to the extent of about 6 million dollars worth, a balance of trade for the Canadian forest product of 12 million dollars is left.

\section{Ownership.}

When the French took possession of the country, all the land belonged to the king, and could be held by others only under feudal tenure, i. e. as a gift under obligation of counter service. The whole country was placed as a fief under the rule of the Hundred Associates, a company which also exercised a trading and colonizing monopoly, but made no success, and was dissolved in 1663. It was then that Richelieu introduced the system of seigniorial tenure, the land being divided into portions of from 100 to 500 square miles, usually with a certain amount of river front, and given outright to younger noblemen, favorites of the court, and clerics, who were, however, obligated to subgrant to colonists, thereby becoming so many immigration agents. These not only treated their colonists as tenants, exacting rent and service, but exercised nearly absolute jurisdiction within their domains, the colonists becoming virtually serfs or retainers of the seigneurs. This condition continued until 1854, when an adjustment of rights was formulated by the Seigneurial Tenures Act, and the government aided the "habitans" to secure their freedom by indemnifying the seigneurs.

Under English rule, the granting of lands, without, however, the seignorial rights, was continued. In 
1784 such grants were made along the St. Lawrence and the Bay of Quinte to veterans of the loyalist army, some 20,000, in lots of 200 acres for privates up to 5,000 acres for field officers. In 1791 every seventh section was ordered to be set aside as Clergy Reserves for the support of the Protestant Church, a measure which created much friction, and formed, especially in the Roman Catholic province of Quebec, a chief grievance in starting the Papineau revolution of 1837. Some $3,300,000$ acres were gradually withdrawn for this purpose, and as far as possible leased to secure an income. Some of these lands were sold after 1827, and finally, in 1853, a statute was passed to sell the remainder and turn over the proceeds to municipalities for educational purposes and local improvement.

Extensive grants and sales were made to lumbermen and speculators. In this manner, by the granting of 13,000 acres to an American, Philemon Wright, in 1800, the great lumber industry of Ottawa was started, and, in 1836, another American syndicate secured about a million acres of grants. Out of the 50 million acres granted in aid of railroad construction, some portion must also have been in timber. By all these methods as well as by small grants and sales to settlers a large area of uncertain extent has become private property.

In Nova Scotia nearly the entire government domain has passed by grant and sale into private hands, one-half in small holdings. Out of 3.5 million acres less than 100,000 acres remain, outside of Cape Breton Island, subject to lease. About 1,500,000 acres of timberland is in private hands. Similarly, in Prince Edward's Island, the 800 square miles of woodland 
remaining are almost wholly owned privately, the 14,000 acres of state land being, like most of the private property, stripped of its value.

In New Brunswick over 1.6 million acres, mostly woodland (containing over 10 billion feet) was granted to the railway company and another million acres or so is in other private possession; a liberal disposal of lands having been continued until 1883, when about 71 million acres of timber and waste land remained to the crown.

In Quebec some 13 million acres are privately owned, of which 5.5 million in woodlots on farms. In Ontario the private woodland area of commercial character may be over 5 million acres.

Besides the large grants which are probably to the greatest extent in timberlands, the farms in the various provinces, according to the Census of 1901 , have from 22 to 57 percent in woodlots, or altogether probably in the neighborhood of 30 million acres.

The largest part of the forest area, however, is still in crown lands, the government of the different provinces and the Dominion government in the territories and in Manitoba administering them and deriving the revenue therefrom. This condition has prevailed since 1837, when the home government gave up its claim to lands and revenues.

The provincial ownership extends over about 500,000 square miles. The Dominion government owns an area of 20,000 square miles in the railway belt of British Columbia, 20 miles on each side of the railway for 500 miles, which contains good timber, and some 
722,000 square miles of land in the territories and in Manitoba which contains only timber suitable for local use.

\section{Derelopment of Forest Policy.}

In the development of ownership conditions the realization of the valuable assets in timber growth had not been overlooked by the home government, care of supplies for naval construction giving, as in the United States, the first incentive to a conservative forest policy.

Even under the early French rule, the grants of land were made under reservation of the oak timber fit for naval use, as is evidenced from a landgrant made in 1683. This reservation led to considerable friction as it hampered the colonists in making their clearings on the best lands. Later the reservation was extended to include other timber needed for military purposes, and when the British occupation began, these established rights of the crown were not only continued, but reservations of entire larger areas for the timber were ordered, notably around and north of Lake Champlain. In 1763, and again in 1775 the home government ordered reservations to be set aside in every township.

But the great timberwealth seemed so inexhaustible that the governors paid little attention to the wise instructions of the home government for the creation of reservations, and whatever regulations regarding the cutting of timber were made, failed to be strictly enforced. In 1789 the policy of reserving to the crown all the timber as far as not granted, and giving licenses to cut, was inaugurated; but not until 1826 was even 
the revenue feature strongly enough realized to attempt systematically to secure the benefit of it by allowing anyone to cut timber "such as was not required for the navy" who would pay a fixed rate for what was cut; a surveyor-general of woods and forests being appointed to collect the timber dues. There was even an attempt made to prevent waste by doubling the rate of timber dues on all trees cut which would not square more than 8 inches; this for lack of supervision probably remained a dead letter.

Lumbermen, however, found it cheaper to buy the land, making only part payments, and after cutting the best timber, forfeiting the land; contractors who had the monopoly for cutting the timber for the royal navy cut also for their own account; corruption and graft pervaded the administration, which enriched its followers with the revenues obtained from the timber licenses. The strong hand which, in the absence of a strong government, lumbermen were driven to use in order to protect themselves from piracy by their neighbors, or else to perpetrate such, brought about many bloody conflicts. This maladministration, besides other grievances, caused the revolution of 1837 , which, although readily put down, led to the union of the provinces of Upper and Lower Canada in 1841, and to reform of the abuses. It was then that, after Lord Durham's admirable report on the situation, the home government turned over the administration and revenues of the crownlands to the several provincial governments. In New Brunswick, where a thriving export trade had been early established the dues on $\$ 2$ million worth of production were involved, and in 
Quebec and Ontario the income amounted to between $\$ 200,000$ and $\$ 300,000$.

But even then the immediate revenue and not any concern for its continuation animated the administration of the public or crown forests. New rules were designed to secure larger returns by introducing competitive bids, a bonus being paid for the limits, (i. e. a limited territory on which the holder or licensee had the exclusive right to cut), in addition to the dues for the timber actually cut. Later, to prevent the holding of timber limits for a rise of prices an annual cut of first 1,000, then 500 feet per square mile of holdings was required. To still further accelerate the use of the licenses to cut, the Crown Timber Act of 1849 limited the license to one year, and provided for an eventual limit in size of the grants. All these provisions forced to more rapid cutting and overproduction, and depression in the timber market was the result, the supply in 1847 being 44 million feet to meet an export of 19 million.

New rules were promulgated in 1851 , introducing a ground rent system, a set price being paid per square mile of limit, and doubling the ground rent for unused limits each year. Needless to say, the impracticability of this geometric progression in ground rents became visible in a few years.

The final present systems in the disposal of timber limits were gradually perfected in varying manner by the several provincial governments, but they agree in general principles, in that they grant limits for a certain time, usually 21 years, during which certain conditions as to establishment of mills and amount of 
manufacture without waste must be fulfilled, and a ground rent, a bonus, and timber dues for all timber cut are to be paid by the limit holder, details and prices varying and being changed from time to time.

A Department of Crown-Lands in the Dominion government and in each province (in Nova Seotia the Attorney-General acting as such) administers the lands. Scalers or cullers attend to the measuring of the cut. The revenue derived by this system by all the provinces amounts now to round 4.5 million dollars per year, Ontario leading with about 18,000 square miles now under license, (mostly pine), producing $\$ 2,650,000$, some 30 million dollars having altogether accrued since 1868; Quebec, with over 62,000 square miles under license, (mostly in spruce,) producing only $\$ 1,167,000$, some 7 million dollars having accrued during the 37 years. Since land for settlement is, as in the United States, obtainable by homestead and other entries, \& good many fraudulent applications under guise of settlement have curtailed the revenue, until now closer scrutiny of the fitness of land for settlement is made.

The retention of the lands by the government is naturally a feature which would permit and should have earlier induced conservative forestry methods, but the immediate revenue interest has had and still has a more potent influence than considerations of the future.

The impetus to introduce conservative features seems to have largely come through the influence of the forestry movement in the United States, and, although, 
voices of prominent Canadians, like that of Sir Henry Joly de Lotbiniere had been heard before in advocacy of a more far-seeing policy, the meeting of the American Forestry Congress at Montreal in 1882 may be set as the date of the inception of this movement in Canada.

The definite result of that meeting was the inauguration of forest fire legislation in the various provinces. In the Province of Ontario, the Fire Act of 1878, which had until then remained a dead letter, was improved, in 1885, by inaugurating a fire ranger system, in which limit holders pay one-half the cost of the rangers. In New Brunswick a fire law was passed in 1885, followed in 1897 by the introduction of the Ontario ranger system. In 1883 Nova Scotia passed a forest fire law, which, like that of New Brunswick, remained ineffective for lack of machinery; this was not provided until 1904, and has worked most satisfactorily. Recently a forest survey of the Province was begun. Quebec also enacted fire legislation in 1883, but did not provide means to carry it into effect until 1889. Since at first only $\$ 5,000$ annually was allowed for its execution, and by 1901-2 not more than $\$ 7,226$ was expended for fire protection over an area of 40 million acres, its effectiveness may be doubted, until, in 1905, a special Forest-Protection Branch, with a ranger system after the Ontario pattern was organized. Ontario in that year, on onequarter the area, had already increased its expenditure for protection to $\$ 34,200$ with effect, and in $1906 \mathrm{ex}-$ pected to spend $\$ 90,000$ from the provincial treasury, in addition to $\$ 70,000$ to $\$ 80,000$ contributed by limit 
holders. The Dominion government has also established a fire ranger system.

The need for more organized effort and advice led to the establishment of special bureaus of forestry. In Ontario a Clerk of Forestry was established in the Department of Agriculture in 1883, and, in 1895, he was replaced by a Clerk, later named Director of Forestry (Mr. Thomas Southworth), in the Crown Lands Department. This office, later, was changed to a Bureau of Forestry and Colonization, and a technically educated man was appointed as Provincial Forester, with a view of developing a forest management, at least in the Reserves. This movement, however, soon collapsed for lack of appreciation; the office was transferred back to the Department of Agriculture, which does not control any timberlands, the Forester resigned, and the bureau was, finally, in 1907 , restricted to the colonization work, the forestry part being deliberately abandoned.

Meanwhile the Province of Quebec pursued a more enlightened course: After organizing the ForestProtection Branch, the government had two foresters educated at one of the American colleges of forestry, and upon their return employed them to supply the technical supervision of cutting on licensed lands, and otherwise to forward forestry reforms. In 1898, a Superintendent of Forestry with a forestry branch was instituted in the federal Department of Interior.

By these agencies the subject was at least kept in the foreground, and while at first hardly more than propagandist literature was produced in their annual reports, gradually, practical work became possible. 
The most important result of this propaganda was to commit the governments to see the propriety of setting aside permanent forest reserves.

The first movement in this direction was made in 1893, and in 1895 the first Dominion reservations were made by the Minister of the Interior. These, to be sure, were located in the thinly timbered parts of the province of Manitoba, the Turtle Mountains and Riding Mountain, mainly for the protection of water supply.

Several other similar reserves were set aside by the Minister, but to give more stability to these reservations an Act of Parliament was passed in 1906, declaring their permanence and placing them under the administration of the Superintendent of Forestry. There are so far, some 26 Dominion Forest Reserves created, comprising an area of over 16,000 square miles. The Forestry Branch is making a brave beginning to survey and manage these reserves under forestry principles.

Of the provinces, Ontario was the first to recognize the principle of reservations in 1893, when a partially cut over, partially licensed territory of over one million acres was set aside as the Algonquin National Park in the Nipissing District; but the first definite establishment of a forest reserve policy dates from the Forest Reserve Act, passed in 1898, which authorizes the Executive, as in the United States, to withdraw lands for reserves. Some five reserves have so far been established, and the reserved area amounts to nearly 12 million acres.

Of management on forestry lines there is so far little to be heard. 
Quebec has followed this example of Ontario, first by setting aside the Laurentides Park in the Saguenay region, (1,634,000 acres), which, like Algonquin Park, was more in the nature of a game preserve. During 1906-7, however, under a law authorizing the Lieutenant Governor to set aside forest reserves, over 100 million acres were placed in reserve. Apparently, however; no administration of this preserve in the forestry sense is as yet attempted.

British Columbia, which until lately was only concerned in disposing of the well timbered crown-lands, after having disposed of the best parts, has placed under reservation the balance, and a forest commission of inquiry has been constituted to devise further measures in the interest of forestry.

Of other attempts to foster forestry interests may be mentioned a law in Quebec, passed in 1882, providing a bonus of $\$ 12$ per acre for tree planting, which seems to have remained without effect; another, providing for a diameter limit of 12 inches on the stump for pine and 9 inches for other kinds, inaugurated in 1888 , may have preserved some young growth on the limits, although, since pulpwood is now the main product, and supervision is inefficient, not much may be expected from such laws.

The Dominion has been active in encouraging treeplanting in the prairies. The Agricultural Experiment Station at Ottawa not only set out object lessons by planting some 20 acres of sample plots, but for a number of years distributed plant material to settlers. This work has lately been taken over by the Forestry Branch and increased to a larger scale, some 160 acres 
being in nursery, and the distribution having grown to $2,000,000$ seedlings per annum.

Ontario, under the direction of its Department of Agriculture and in co-operation with the Agricultural College at Guelph, has lately embarked in two movements of amelioration, namely, establishing a State nursery from which plant material at cost, with advice as to its use, is given to farmers, and purchasing and reforesting waste lands in the agricultural section.

Tariff legislation is another means which is in the hands of the Dominion government to be used for encouraging forest conservancy. It has, however, so far not been used directly for such purpose, fiscal and commercial policies being uppermost. But by encouraging manufacture rather than export of raw materials, indirectly the effect must have been in the direction of more economic use of forest resources.

Meanwhile private limit holders, here and there, had begun to see the need of conservative methods, and by 1908, at least two large Paper and Pulp concerns had placed foresters in charge of their logging operations.

Until 1900, associated effort to advance forestry in Canada had relied on the international American Forestry Association. In that year, largely through the officials of the Dominion Forestry Branch (Mr. E. Stewart), the Canadian Forestry Association was formed.

This Association has grown more and more vigorous, and having escaped the period of sentimentalism which in the United States retarded the movement so long, could at once accentuate the economic point of view and bring the lumbermen into sympathy with their 


\section{Forest Policy.}

effort. In 1905, a quarterly magazine, the Canadian Forestry Journal was started by the Association, making its work of instruction and propaganda more effective.

A most promising convention held in January 1906, with the Premier of the Dominion presiding, participated by prominent officials and business men, seemed to foreshadow the time when a real rational forest management, at least in some parts of the Dominion would be inaugurated.

But it can can hardly be said that the expectations were realized. In 1909, following the precedent of the United States, a Conservation Commission was appointed, from whose activity perhaps better results may be expected.

While the Ontario government had directly discredited the forestry movement by abolishing its bureau of forestry, indirectly it laid the foundation for a sure future, in 1907, by establishing in its provincial University at Toronto a Faculty of Forestry with full equipment. A year later the Province of New Brunswick also established a chair of forestry in its University, while some time earlier the Guelph Agricultural College had introduced the subject of farm forestry in its curricula. 


\section{NEWFOUNDLAND.}

Newfoundland, probably the first discovery of America by the Norsemen, remained a mere fishing station until modern times, and, except for the open coast, unknown as regards the wooded interior, which was supposed to be largely barren. It became a possession of Great Britain in 1713. Development did not begin until 1880 when the first railroad was built, and has progressed more rapidly since the Newfoundland Railway traversing the entire island was opened in 1898. It was found that while the shores and a considerable part of the West and South coast are barren or poorly timbered, and on the interior plateau large moss barrens exist, there are extensive timber areas of mixed growth, White and Red Pine, Balsam and Spruce, with White Birch. A lumber industry, which by 1904 had grown up to probably not less than 100 million feet, is rapidly extending over the whole island, and an extensive paper pulp industry is preparing to establish itself, on timber limits under a license system similar to that applied in other parts of Canada. Some 5000 square miles are now under license. Forest fires have repeatedly devastated large areas, especially in 1904. The experience of that year led to the enactment of a forest fire law, but without any agency to make it effective.

No forest policy exists, except the commercial restriction of the license system. A forestry association has lately been formed. 


\section{OTHER BRITISH POSSESSIONS AND COLONIES.}

Under the influence of the Indian forest service, or stimulated by its success, some of the other British Colonial governments in Africa and Australia have attempted and sometimes succeeded in establishing a forest policy.

Of East Indian territories Ceylon, the nearest neighbor to India, with over 25,000 square miles, of which 42 percent wooded, mostly with second growth forest of small value, attempted long ago an organization with the aid of Indian foresters, but by $1900 \mathrm{had}$ of over 10,000 square miles only 431 in reserves, in addition to nearly 1800 acres planted. One Conservator and 8 Assistant Conservators produce a net revenue of less than $\$ 30,000$, there being an import of $\$ 250,000$ necessary to eke out the wood requirements of the 3.5 million people.

The Straits Settlement, an area of 1526 square miles, had by 1900 a reserved state forest area of 138 square miles under an experienced Indian forest officer. Gutta percha, rubber and gums are here the most valuable products.

The Federated Malay States, with 26,350 square miles, and heavily wooded, after a report by the Indian Inspector General, have begun to reserve forest areas, some 100,000 acres having been set aside, which are administered by the Conservator of the Strait Settlement's reserves.

The government of the island of Cyprus also employs a forest officer and guards to look after its 700 square miles of forest. 
In Africa, during the last few years small forest departments have been established by the governments of the Soudan, East Africa, Nigeria, Transvaal, Orange River and Natal, mostly for the purpose of planting on the treeless plains.

The government of Mauritius had made attempts at conservancy for many years, but without notable success.

The most successful attempt in Africa so far is reported from Cape Colony, which as early as 1819 had a Superintendent of Lands and Woods, and in 1876 a Department of Forests and Plantations, neither of which have left much of record.

In 1881 a new forest department under a French forest officer was started, which has grown until now its consists of one Conservator (D. E. Hutchins), 22 Assistant Conservators, 84 European foresters, and a few native guards. In 1888 the needed legislation was had for regulating the working of the nearly half million acres of forest area, which, in 1902, was declared inalienable government property. Since the wood imports amount to over two million and a quarter dollars annually, the need of conservative use is appreciated especially as climatic conditions are unfavorable to reproduction. Some 24,000 acres have been planted during 22 years, at a cost of $\$ 1,500,000$, the first plantations beginning to yield a substantial revenue, and it is believed that another 40,000 acres of such plantations would supply all the timber needed in the Colony. Treeplanting by private land owners and municipalities is encouraged by furnishing advice gratis and plant material at low cost, and to 
municipalities in addition government aid is extended to the extent of half the cost of planting.

The seven Australian colonies are very variously situated regarding timber supplies, three of them, Queensland, Western and South Australia being poorly wooded, the others more or less heavily forested, especially Tasmania with 65 percent, and New Zealand with 31 percent. Generally speaking the forest areas are confined to the coast in narrower and wider belts, the interior being forestless or with scrubby growth. This portion is large enough to reduce the total forest percent to less than 6.5. The mountains and hill ranges facing the Eastern, Southern and Western coasts are especially heavily wooded with magnificent Eucalypts, Jarrah and Karri, while the Kauri pine is the most valuable tree in New Zealand.

The one successful attempt at a forest policy was made by the almost forestless colony of South Australia, which in 1882 reserved its scanty forest area of 217,000 acres and started to plant, (now 13,000 acres planted), employing a Conservator and six Foresters.

In the other colonies at various times unsuccessful beginnings were made, and there exist in Queensland, New South Wales, and Victoria so-called Forest Branches or departments, but mostly without power or equipment, and no intelligent conception of forest policy seems practically to exist.

In Queensland, since 1897, the Governor in Council may reserve forest lands and regulate the cutting by diameter limit. One and a half million acres have been reserved, but no staff for administration exists. 
In New South Wales six million acres were withdrawn from settlement, but it is mostly used for pasture, and withdrawal may be revoked at any time. No effective system of control exists.

In Victoria five and a half million acres have been declared reserves under act of 1890 , nearly half the forest area. There exists a forest department of one Conservator, two Inspectors and 25 Foresters, but no plan of management. Four State nurseries of doubtful value seems the whole result.

The other colonies still merely exploit their forest resources under loosely managed license systems, without even an inefficient attempt at intelligent treatment. 


\section{JAPAN.}

The modernization of this remarkable island empire of Niphon (the native name), which began in 1868, included the organization of a forest department after German models. Curiously enough, there are other noteworthy points of similarity to be found in the historic development of forestry in Germany and Japan.

The empire comprises four larger islands-Kiushiu, Shikoku, Hondo or Honshiu, and Hokkaido or Yessoand a host of smaller ones, stretching in a chain of nearly 3,000 miles north and south along the Asiastic shore, the width of land being nowhere over 200 miles. It comprises an area of nearly 150,000 square miles, with a population approximating 50 million, largely engaged in fisheries and other sea industries.

The islands are of volcanic origin-part of the "girdle of fire" which reaches from the Alaska peninsula through the Philippines to the Antilles-with many ac-

Forestry of Japan, 2904 , published by the Imperial Bureau of Forestry in connection with the Louisiana Purchase Exposition, contains most of the information utilized above.

Aus den Waldungen Jopan's, by Dr. Heinrich Mayr, $189 \mathrm{x}$, gives a full account of the forest geography, which is alwo to be found in J. J. Rein, Japan, 1886.

Der Wald in Japax, an article by Dr. Hefele in Forstwissenschaftliches Centralblatt, 1903 , gives an insight into forest conditions from the point of view of a forester.

A very clear analysis of the development of property rights is to be found in an article by Dr. Zentaro Kawase in Allgemeiae Forst.and Jagdreitung, 1894.

An article in Zeitschrift für Forst-und Jagdwesen from the pen of Prot. H. Matsuno, the first professional forester of Japan, gives a brief account of the development of forestry, especially in earlier times.

A report by Special Canadian Trade Commissioner W. T. R. Preston, xgo8, contajus valuable statistics on the lumber trade. 
tive craters, subject to frequent disastrous earthquakes and tidal waves; mountainous, with numerous ranges of high hills and with lofty central ridges, with numerous short rivers, apt to turn into treacherous torrents, while hurricanes and waterspouts, typhoons and equinoctial gales sweep the surrounding seas frequently.

The soil is nowhere particularly fertile, but the patient and painstaking labor of the Japanese has brought every available foot of it-little more than $10 \%$ is arableinto producing condition, wherever the climate compensates for the infertility, especially in the most densely populated part, the southern half of Hondo.

Extending through 30 degrees of latitude, the climate naturally varies from the tropical one of Formosa, through all variations of the temperate, to the alpine one of the high mountains and the nearly arctic one of the Kurile islands. The Japan current skirting the eastern coast, and the mountain ranges, with elevations generally not exceeding 6,000 feet, occasionally up to over 13,000 feet, which cut off the dry continental west winds, also produce great climatic variations between east and west coasts. In general, however, the climate of the whole empire is characterized by a high percentage of relative humidity and ample rainfall, especially during the hot season, producing luxuriant growth.

\section{Forest Conditions.}

Due to these great variations in climate, the forest flora of Japan almost rivals in variety that of the United States, with over 200 deciduous, and more than 30 coniferous species of size (besides a large number of half-trees), although not more than some 50 or 60 are 
of silvicultural importance, and not more than 10 or 12 species form the basis of forest management and of the lumber trade, which requires some two billion cubic feet annually, and supports an export of over six million dollars. The value of the total cut was, in $190 \%$, placed at over 17 million dollars, of which six million was to the credit of the State Treasury.

In the tropical districts, bamboos form the main staple; in the subtropical region, the most densely populated and hence also almost forestless, the broadleaf evergreens, especially several species of oak, furnish desirable fuel wood, and two species of pine are most valued for timber, one, the Red Pine ( $P$. densiflora) extending its realm rapidly over waste areas; camphor tree and boxwood furnish ornamental wood.

The region of temperate forest furnishes, out of over 60 species, some 14 conifers and 19 broadleaf trees of value, the former mainly of the cedar tribe, with Cryptomerit Japonica the most widely used, while of the broadleaf species, which occupy more than 50 per cent. of the forest area, Zelkowa Keaki, of the elm tribe, a chestnut, a beech, several oaks, a walnut, and an ash count among the mast useful.

Spruce, Fir, and White Birch are the trees of the northern forest.

Mixed forest forms $45 \%$, broadleaf $25 \%$, conifer $21 \%$, and $9 \%$ is rated as blank or thinly stocked.

The forest area, which, over the whole, covers more than $59 \%$ of the land area, or around 58 million acres ( $1 \frac{1}{4}$ acres per capita), is quite unevenly distributed according to topography and population, being mostiy confined to the mountain ranges and hills which form the 
backbone of the country, and to the northern provinces. Hokkaido, which was opened up to colonization only 35 years ago, now with a population of only 20 to the square mile, has $66 \%$ of forest, 15 acres per capita; the northern part of Hondo has a similar area per cent., mostly on the high steep mountains, but only 1.2 acres per capita; on the southern portion, the low ranges of hills and valleys, the forest area has been reduced to $53 \%$, but shows only three-quarter acre per capita; and Okinawa, with $26 \%$, and less than one-third acre per capita, shows the lowest.

Of this forest area, however, almost one-half is "hara," brush forest, chaparral, or dwarfed tree growth-the result of mismanagement, excessive cutting and firesand impenetrable thickets of dwarf bamboo, which crowd out tree and even shrub growth wherever such mismanagement gives it entrance. These extensive haras are cut every two to five years for the brush, which is used to cover and furmish manure for rice fields.

Fire, which, until lately, ran over 5 or 6 million acres annually, and ruthless cutting, have in the past and are still deteriorating the forest area.

Grassy prairie and barrens due to natural conditions are not absent, and are due to excessive drainage through loose coarse-grained rock soil; they are found, not extensively, at the foot of volcanoes, and on highest elevations. The differentiation of land areas is not quite certain. In 1894, there was still $30.5 \%$ of grassy prairie reported, but some of this, no doubt, was forested, probably one-half.

The bulk of the forest area is owned by the State and the Imperial Household. Communal forests are estimated to aggregate somewhat over four million acres 
(7.5\%) and private property some 18 million (26\%), leaving 30 million for the State and for Imperial or Crown forests $(66 \%)$, the latter comprising some $\mathbf{5 . 5}$ million acres.

These figures are liable to variation, due to sales of the latter class, and to adjustments of the somewhat obscure property rights.

The ownership by the State and a conservative use of the mountain forest is necessitated by the protective value of the forest cover, the cultiration of the extensive rice fields being dependent upon irrigation.

\section{Development of Forest Policy.}

The history of Japan dates back to 660 B. C., when the empire was founded on the island of Kiushiu by the warrior king Jimmuteno. He established a kind of feudal government, with the daimios (knights or barons) holding their fiefs from the mikado, who was considered the sole owner of the soil, or at least all exercise of ownership rights emanating from him. Private property seems then not to have existed at all, the people having merely rights of user. Colonization of the islands brought under the mikado's dominion progressed rapidly, and with it, not only arable portions but even mountains were denuded.

With the beginning of the Christian era the need of better protection against floods seems to have been recognized, and, in 2\%0 A. D., we find the first forest official appointed, a son of the royal house, who with assistants was to regulate the use of the forest property, which, under the rights of user granted by the mikado, was being excessively exploited and devastated. 
In the fifth century the feudal method of giving fiefs of land and forest to the deserving vassals had come generally into vogue, and later, with the rise of Buddhism forests were assigned to the temples and priest's, who, as in Germany the monks, were assiduous in cultivating and utilizing them.

Soon the daimios, similarly to the barons in Germany, began to assert exclusive property rights, and, notwithstanding various edicts, issued from time to time to secure free use to the people, more and more of the forest area was secured by daimios, and by priests as temple forests.

In the ninth century, deforestation and excessive exploitation had so far progressed that not only the need of protecting watersheds was recognized by edicts, but fear of a timber famine led even to planting in the province of Noto.

A period of internal strife and warfare during the following centuries which left forest interest in the background led, in 1192, to the establishment of the rule of the shoguns, the hereditary military representatives of the mikado, who made him a mere figurehead, and exercised all the imperial functions themselves, until the revolution of 1868 restored the mikado to his rights.

The effort at conservative forest use was renewed with increased harshness when, after a period of warfare and devastation, the great shogun family of Tokugawa (1603) assumed the rule of the empire, enforcing the restrictive edicts with military severity. Even at that early age, the protective influence of forest cover on soil and waterflow was fully recognized, and a distinction of open or supply forest and closed or protection forests 
seems to have been made, the latter being placed under the ban of the emperor or shogun, and withdrawn from utilization. The extensive forests of the province of Kiso, the best remaining, owe their preservation to these efforts. The daimios, 260 in number, each in his district, enforced the edicts in their own way, giving rise thereby to great differences in forest administration; yet, in the absence of technical knowledge, deterioration continued. The severity of punishments for depredations, etc., reminds us of those of the German Markgenossen, a hand or finger being the penalty for theft, death by fire that for incendiaries.

The idea of protecting or reserving certain species of trees, which was practiced in India by the rajahs, we find here again in the beginning of the 18 th century, the number of such protected species varying from one to seren and even fifteen in different districts. Another unique and peculiar way of encouraging forest culture was to permit peasants who made forest plantations in the State forests, to bear a family name, a right which was otherwise reserved to the knights or samurli, or to wear a double-edged sword like the latter. Arbor days were also instituted, memorial days and festivities, as at the birth of children, being marked by the planting of trees.

While in Germany the love of hunting had led to the exclusion of the people from the forests, in Japan it was a question of conserving wood supplies that dictated these policies.

It is claimed that to these early efforts is due the preserration of the remaining forests. But, while this may be true in some instances, as in the province of Kiso, 
more probably their distance from centers of consumption and their general inaccessibility preserved those of Kokkaido and of the northern mountains. Certainly the brush forests south of Tokyo do not testify to great care.

The detested shogunate was abolished in 1867 by a revolution which brought the mikado to his rights again and crushed the power of the daimios, whose fiefs were surrendered, and their acquisitions of forestry property, as well as (a few years later) those of the priests, were declared State property, with the exception of some which were recognized as communal properties.

Similar to the experiences of France, the disturbances in property conditions, which implied instantaneous loss by the people of all rights of user in the State property as well as removal of all restrictions from private and communal properties, led to wholesale depredations from the State domain, and to widespread deforestation and devastation, an area of a million acres of burnt waste near Kofu, west of Tokyo, testifying to the recklessness of these times.

Without any force to guard property rights, stealing on an extensive scale, similar to past experiences in the United States, with the accompanying wastefulness, became the order of the day, and is even now not uncommon.

A first provisional administration of State forests was inaugurated and a forest reconnaissance ordered in 1875 , in order to secure insight into the mixed-up property relations, and restore to their rightful owners such portions as had been wrongly taken by the State.

In 1878 , the State forests were placed under a special 
bureau, organized by Matsuno, who had studied forestry in Germany (Eberswalde) for five years. But it was not academic knowledge that was needed in the situation; it was necessary first to mould public opinion in order to secure means for administrative measures.

This he set himself to do through public addresses and pamphlets, and by organizing a society of friends of forest culture, and finally, in 1882, by establishing an experiment station at Nishigahara, and, a year later, a dendrological school, which four years later was combined with the agricultural school at Komaba; five years later both were joined to the University of Tokyo.

With the transfer of the forestry bureau to the Department of Agriculture and Commerce in 1881, and a reorganization in 1886 , a new era seemed to be promised, yet a substantial progress in organized forest management of the State property does not seem to have been made for another decade at least, the slow progress being largely due to lack of personnel and the continuance of mixed property conditions, which involved not only uncertainty of boundaries, but also mixed ownerships.

Although this last trouble, namely of mixed ownership by State and private individuals, had been recognized as inimical to good management, it was deliberately increased by the law of 1878 in a curious way, re viving an old custom, namely, by permitting private inviduals to plant up clearings in the State forests; in this way, these individuals secured a certain percentage, usually 20 per cent., of the eventual profits arising from the results. Some 200,000 acres were planted under this arrangement.

To remove the boundary difficulty, a survey of the 
boundaries of State property and adjustment of property rights, as well as segregation of the State lands to be disposed of, namely small lots and others not needed, was ordered in 1890.

It was then also that the first provisional working plan for the fellings on State lands was elaborated, and gradually with the progress of the survey, more permanent plans were adopted for district after district.

By 1899, the adjustment had progressed far enough to begin the restoration of properties, which the State had improperly claimed, to their proper owners. It was then also that the Imperial forests, intended for the support of the Imperial household, were increased to about 5 million acres.

Meanwhile the personnel had increased in numbers and improved in character. In 1904, the organization of the forestry bureau under the Minister of Agriculture and Commerce, arranged somewhat after German models, consisted of one director and four forest commissioners with ten clerks, forming the head office; the sixteen districts into which the State forests were divided were presided over by 32 conservators and 80 inspectors, while 325 district officers with 880 assistants and 626 guards, altogether over 1,800 employes, formed the field force. This arganization applies to the State forests under control of the Department of Agriculture. Strangely enough, those in Hokkaido and Formosa are not under that department, but under the supervision of the Minister of Home Affairs, while the Imperial forests are under the Household Department.

The need of supervision of the ill-managed private and communal forests, mostly located near the settled 


\section{Forest Policy.}

portions, early attracted the attention of the new regime, mainly on account of their protective value. Annual losses through floods to the amount of four million dollars, and similar losses due to unchecked forest fires, gave the incentive to the passage of a law, in 1882, simply forbidding all forest use in protection forest, which, simple prescription evidently did not work until a further revision was made in 1897 . This latter does not confine itself to legislation for protection forests alone, but also authorizes the supervision of supply forests, under the special control of the local governors. Under this law, which also extended the assistance of local authorities to would-be planters, aided by reforms in the corporation system, remarkable activity in planting waste lands ensued, so that in the next two years not less than one million acres of communal property was set out with trees, numbering over 800 million, while in the State forests, some 200,000 acres of vacant land had been planted by 1901. Some sand dune planting and reboisement works are also the result of this legislation.

In connection with this planting, it may be of interest to record the attitude of Japanese foresters toward natural regeneration: "This is no longer popular in these days when the knowledge of forest management possessed by foresters has become highly developed, for if that method is the easiest and least troublesome, nevertheless it is not advisable, in view of the necessity of effecting a thorough improvement in our silvicultural conditions. Only on steep slopes and for protection forests is it applicable."

In $189 \%$, also, some eight experiment stations were organized, in addition to the earlier one at Nishigahara organized in 1882 by Matsuno. 
Education in forestry has lately run riot in Japan as it has in the United States. Since the first school, organized in 1882, not less than 62 institutions have seen the need of offering the opportunity to become acquainted with that subject. Here, however, different grades are frankly acknowledged. There are three collegiate institutions whose diploma admits to the higher service, five are of secondary grade, another five give special courses, and the rest treat the subject merely as a subsidiary of a practical education including agriculture, stock-farming and fishery. A ranger school, which was instituted under Matsuno's guidance, controlled by the forestry bureau, came to an end during the Russian yar for lack of funds, but has probably been revived again.

In conclusion, we may say that Japan has done wonders in reorganizing its forestry system in a short time, but, according to one competent observer, while all the Japanese care for detail and love for orderliness is apparent in the office, not all that is found on paper is to be found as yet in the woods, and that for similar reasons as have been indicated for Russia, many things happen in the woods that are not known in the office.

\section{KOREA.}

The latest move in forest reform in this part of the world, as a result of Japanese influence, is to be recorded from Korea. The forest area of Korea comprises only about 2,500,000 acres, out of an area of nearly 60 million acres of very mountainous country. A concession for the exploitation of the northern forests to a Russian, which included the re-planting with "exotic" 
tree species, was the immediate cause of the RussoJapanese war. Now, in 190\%, by co-operative arrangements with Japan, a conservative forest policy has been inaugurated by laws similar to those of Japan.

Drouth, floods and erosion of soils have been common experiences. The preservation of forest cover, especially at the headquarters of the Yalu and Tumen in the northern part of the country, is aimed at.

For this purpose the government has taken all forests under its care. All private owners or lease holders must report their holdings and have their property listed, and in case of failure to do so the property is forfeited. The government may then expropriate, or else regulate the cutting, or, where protective functions of the forest cover require it, may forbid cutting altogether.

A forestry school is also part of the program. 


\section{UNITED STATES OF AMERICA.}

The great and exuberant republic of the United States, vast in extent and rich in natural resources generally, excelled and still excels in extent, importance and value of her timber resources; and, having only lately begun to inaugurate rational forest policies, promises to become of all-absorbing interest to foresters.

The marvelous growth of the nation, which from three million in 1780 had attained to a population of 76 million in 1900, and, by the next Census will number around 100 million people, has been the wonder of the world by reason of its rapid expansion; and yet the limit is far from being reached. Annually some three-quarters of a million or more immigrants from all parts of the world arrive, and there is still room and comfortable living for at least another 100 million, if the resources are properly treated.

The large land area of nearly two billion acres (over three million square miles) is undoubtedly the richest contiguous domain of such size in the world, located

Report upon Forestry, 1878-9, by Dr. F. B. Hough; contains references to the earlier history of forest development.

History of the Lumber Industry, by J. E. Defebaugh, rgo6-7; is valuable as a reference to statistical matter.

Report upon Forestry Investigations of the United States Department of Agriculture, 1877-1898, by B. E. Fernow. House Document No. 181 , 55th Congress; contains amplifications of the matter contained in this chapter.

Annual and other reports issued by the Department of Agriculture, by the various State Forest Commissions, and Forestry Associations.

For latest developments, consult Conservation and Forestry Quarterly. 
most favorably with reference to trade by virtue of a coast line of over 20,000 miles, and diversified in climate so as to permit the widest range of production.

While a simple mathematical relation would make the population at present about 28 to the square mile, such a statement would give an erroneous conception of economic conditions, for the distribution of the population is most uneven, a condition which must eventually diversify the application of forestry methods in different parts of the country. In Massachusetts and Rhode Island combined, for instance, the density of population is 380 to the square mile, exceeding that of the similar-sized State of Wurtemberg in Germany, while in the neighboring State of Maine it is not 22; the Atlantic Coast States south to South Carolina, a territory slightly larger than Germany, show about half, and the Central agricultural States about one-third the density of that densely populated country; on the other hand, some of the Western States, Montana, Idaho, Nevada, Arizona and New Mexico hare less than two to the square mile.

Similar unevenness is found in the distribution of resources, especially of timber wealth; and, to some extent at least, the present populational distribution is explained by the uneven distribution of farm soils and timber.

Outside of the unorganized territory of Alaska and the disfranchised District of Columbia, the country is divided into 46 States and five Territories which will erentually acquire statehood. In addition, there are a number of insular possessions under the direct control of the federal government. Each State being under 


\section{United States.}

Jonstitution sovereign in itself as far as its internal administration is concerned, it is evident that no uniformity of policies can be expected, except so far as imitativeness, in which the American citizen excels, may lead State after State to repeat the experiment attempted by one. The federal government has no direct jurisdiction in matters concerning the management of resources within the States, except so far as it still owns lands in the Western, so-called Public Land States, and a few parcels in the Eastern States over which it still retains jurisdiction.

The severest test of democratic institutions is experienced when the attempt is made to establish a policy which shall guard the interests of the future at the expense of the demands and needs of the present. Democracy produces attitudes and characteristics of the people which are inimical to stable economic arrangements looking to the future, such as are implied in a forest

$\wedge$ policy. The vast country with an unevenly distributed and heterogeneous population presents the greatest variety of natural, as well as of economic conditions; the immediate interests of one section naturally do not coincide with those of other sections; particularistic and individualistic tendencies of the true democrat are antagonistic to anything which smacks of "paternalism", under which alone a persistent, farsighted policy can thrive. Frequent change of administration, or at least the threat of such change, impedes consistent execution of plans; fickle public opinion may subvert at any time well laid plans which take time in maturing; the true democratic doctrine of restricting State activity to police functions, and the doctrine of non-interference 
with private rights, as well as the idea of State rights in opposition to federal power and authority-all these characteristics of a democratic government are impediments to a concerted action and stable policy.

That, in spite of these antagonistic interests, conditions and doctrines, substantial progress toward establishing at least a federal forest policy has been made, is due to the fact that the American, in spite of his reputation as a materialistic, selfish opportunist, is really an idealist; that he responds readily to patriotic appeals; that, in spite of his rabid nationalism, he is willing to learn from the experiences of other nations; that, indeed, he is anxious to be educated. Finally, much credit is due to the men who with single purpose devoted their lives to the education of their fellow citizens in this direction.

It must, to be sure, be added that remarkable changes in the political attitude of the people have taken place in the last 30 years since the propaganda of forestry began; changes, partly perhaps induced by that propaganda, which have aided this movement, and which, if they persist, promise much for the future development of forest policies. A decidedly paternalistic, if not socialistic attitude, has lately been taken by the federal government; and by skilful construction of the Constitution as regards the right to regulate interstate relations, has led to an expansion of federal power in various directions. A similar paternalistic attitude has dereloped in the legislatures of several States to a noticeable degree. Eren the judiciary has taken up this new spirit, and is ready to sanction interference with private property rights to a degree which, a decade ago, would 
have been denounced as undemocratic and tyrannical. Two courts have lately ruled that owners of timberlands may be restricted, without compensation, as regards the size of trees they may fell on their property, if the welfare of the State demands such interference.

The argument of the Roman doctrine utere tuo ne alterum noceas, which forestry propagandists have so strenuously used, seems finally to have found favor, and the inclusion of the community at large, present and future, as the possibly damaged party does not appear any more strained. The idea of the providential function of governments, as the writer has called it, seems to have taken hold of the people. The democratic doctrine of State rights, and restriction of government functions has, even among Democrats, been weakened through the long continued reign of the Republican party, the party of centralizing tendencies, so that the latest Democratic platform of a Presidential campaign (1908) outdid the Republican platform in centralizing and paternalistic propositions.

It is proper to emphasize the growth of this socialistic attitude, as it is bound to influence, and influence favorably, the further development of forest policies.

Nevertheless, it is still necessary to keep in mind that the States are autonomous, and that, while the federal government, in spite of the antagonism in the Western States, in which the public lands are situated, has been able to change its land policy from that of liberal disposal to one of reservation, it alone cannot save the situation. While a few of the States have made beginnings in working out a policy to arrest the destruction of their forest resources, which are mostly 
in private hands, still much water must flow down the Mississippi before adequate measures will be taken to stave off the threatening timber famine, and the energy of the various local and national Conservation associations will need to be exercised to the utmost.

\section{Forest Conditions.}

Two extensive mountain systems, running north and south, give rise to at least eight topographic subdivisions of the country, going from east to west.

1. The narrow belt of level coast and hill country along the Atlantic shore, from 100 to 200 miles in width, with elerations up to 1,000 feet, but especially low along the seacoast from Tirginia south; drained by short rirers navigable only for short distances from the mouth; a farming country, with the soils varying from the richest to the poorest; some 300,000 square miles.

2. The Appalachian mountain country, nearly of the same width as the first section, with elevations up to 5,000 feet; the watershed of all the rivers to the Atlantic, of sereral rivers to the Gulf, and of the eastern affluents of the Mississippi; a mountain country, of about 360,000 square miles extent, rich in coal, iron and other minerals, except in its northern extension formed of archaean rock.

3. The great river basin of the Mississippi, a Central plain of glacial and river deposit, rising gradually from the Gulf to the headwaters for more than 1200 miles and nowhere orer 1,000 feet abore sea lerel; the richest agricultural section, ‘00,000 square miles, more or less. in extent. 
4. The plateau, rising towards the Rocky Mountains from 1,000 to 5,000 feet above sea level, some 870,000 square miles in extent, a region of scanty rainfall, hence of prairie and plain, but mostly rich soil of undetermined depth, capable of prolific production where sufficient water supply is available.

5. The Rocky Mountain region, rising from 5,000 to near 10,000 feet (except some higher peaks), an arid to semi-arid district of rugged ranges, covered mostly with forest growth, often open and of inferior kind, with tillable soils in the narrow valleys, requiring irrigation for farm use; a mining country, rich in gold and silver, extending over 150,000 square miles.

6. The Sierra Nevada Mountain Range, including the Coast Range, rarely over 7,000 feet elevation, arid to semi-arid on the Eastern slopes; humid, and supporting magnificent forest growth on the Western slopes; some 190,000 square miles.

7. The Interior Basin, lying between the two preceding mountain ranges, some 400,000 square miles; for the most part a desert, although in parts supporting a stunted growth of pinon and juniper, and, where irrigation is possible, productive.

8. The interior valleys of the Sierra, comprising about 30,000 square miles, which, under irrigation, have become the garden spots of the Pacific.

To these topographic subdivisions correspond in part the climatic and the forest conditions, although variation of soil and of northern and southern climate produce further differentiation in types, and in distribution of field and forest. 
The first three sections were originally densely wooded-the great Atlantic forest region-but farms now occupy most of the arable portions; the fourth and seventh are forestless, if not treeless, while the fifth and sixth were more or less forested-the Pacific Coast region.

Floristically also, these topographic conditions are reflected, namely in the wide, north and south distribution of species, unimpeded by intervening mountain ranges, and in the change in composition from east to west. The two grand floristic divisions of the Atlantic and the Pacific forest, having but few species in common, are separated by the plains and prairies. The Atlantic forest is in the main composed of broadleaf trees with conifers intermixed, which latter only under the influence of soil conditions form pure stands, as in the extensive pineries of the South and North, and in the northern swamps and on southern mountain tops. The central region west of the Alleghanies exhibits little conifer growth in its composition, and is most widely turned to farm use. White Pine, hemlock and spruce are the important coniferous staples of the northern section, and a number of Yellow Pine species, with Bald Cypress and Red Cedar, are the valuable conifer species in the South. As regards valuable hardwoods, there is but little change from north to south.

The Pacific forest flora is almost entirely coniferous, but here also climatic conditions permit a distinction of two very different forest regions, the Rocky Mountain forest being mostly of rather inferior development, and the Sierra forest exhibiting the most magnificent tree growth in the world. 
Nearly half the country is forestless, grassy prairie and plain, some 400 million acres being of the latter description, while open prairie and brush forest, or waste land occupies 600 million acres.

Within the forest region of the East some 250 million acres have been turned into farms, leaving still twothirds of the area either under woods, or else wasted by fire. Although any reliable data regarding this acreage are wanting, the area of really productive woodland in this section may probably be set down as not exceeding 300 million acres, which would be nearly $40 \%$ of the total area, varying from $13 \%$ in the Central agricultural States to $50 \%$ in the Southern States; Maine, New Hampshire and Arkansas being most densely wooded, with over $60 \%$. The Rocky Mountain and Sierra forests, each with 100 million acres, would bring the total productive woodland area to a round 500 million acres, or about $26 \%$ of the whole. (Later estimates increase this area to 550 million acres.)

It is almost idle to attempt an estimate of the timber still standing ready for the axe; not only are the data for such an estimate too scanty, but standards of what is considered merchantable change continuously and vitiate the value of such estimates. The writer's own estimate, made some years ago, of 2,500 billion feet, which by others has been treated as authoritative and forming a basis for predicting the time of a timber famine, must be considered only as a reasonable guess, ventured for the purpose of accentuating the need of more conservative treatment of these exhaustible supplies, in comparison with the consumption which repre- 
oents around 40 billion feet B. M., and altogether 20 million cubic feet of forest-grown material, the ultimate value of all forest products reaching the stupendous sum of around 1,200 million dollars. And as in other countries, this lavish consumption of forest growth, from five to fifteen times that of Europeans, has shown in the past a per capita increase of 30 per cent. for every decade.

The bulk of the standing timber is to be found along the Pacific Coast, in the Sierra, and in the Southern States with their extensive pineries; the Northern and Eastern sections are within measureable time of the end of their virgin supplies of saw timber. The practice of culling the most valuable species has changed the composition in the regeneration, making it inferior, and large areas have been rendered worthless by fires.

The loss by fire, the bane of American forests, as far as loss in material is concerned probably does not exceed 2 or 3 per cent. of the consumption, and may be valued at say 25 million dollars per annum. But the indirect damage to forest and soil, changing the composition, baring the soil, and exposing it to erosion and washing, turning fertile lands into wastes, and brooks and rivers into torrents, is incalculable.

There is no doubt that at the present rate of consumption the bulk of the virgin supplies will be used up in a measurable time, which will force a reduction in the use of wood materials; a more or less severe timber famine is bound to appear,-indeed, has begun to make its appearance; and all recuperative measures will not suffice to stave it off, although they may shorten the time of its duration. 


\section{Early Forest History.}

The early colonizers, settling on the Atlantic Coast soon after the discoveries of Columbus, did not, as is usually believed, find an untouched virgin forest. The aboriginal Indians had, before then, hewn out their corn fields, and had supplied themselves with fuel wood and material for their utensils; and fires, accidental, intentional, or caused by lightning, had, no doubt, also made inroads here and there. The white man, to be sure, is a more lavish wood consumer; his farms increased more rapidly, his buildings and his fireplaces consumed more forest growth, and carelessness with fire was, as it is still, his besetting sin. Moreover, a trade in timber with the Old World developed, in which only the best and largest sized material figured. Wastefulness was bred in him by the sight of plenty, and the hard work of clearing his farm acres incited a natural enmity to the encumbering forest.

The first sawmill in the New World was erected in 1631 in the town of Berwick, Maine, and the first gang saw, of 18 saws, in 1650 in the same place, * while, before that time, masts and spars, handmade cooperage stock, clapboards and shingles formed commonly parts of the return cargoes of ships. By 1680 , nearly 50 vessels engaged in such trade cleared from the Piscataqua River.

The ordinances on record which were issued at the same early times by the town governments of Exeter (1640), Kittery (1656), Portsmouth (1660), and Dover (1665), restricting the use of timber, remind us of the early European forest ordinances; they were probably

*See Forestry Quarterly, vol. IV, p, s4. 
not dictated by any threatening deficiency of this class of material, but merely intended to secure a proper and orderly use of the town property.

The appointment of a Royal Surveyor of the Woods for the New England colonies in 1699, and the penalties impased in New Hampshire (1708) for cutting mast trees on ungranted lands ( $\$ 500$ for cutting 24-inch trees), and in Massachusetts (1784) for cutting White Pine upon the public lands $(\$ 100)$, were probably also merely police regulations, to protect property rights of the Crown or commonwealth. That this last move was in no way conceived as a needed conservatism is proved by the fact that two years later the Legislature of Maine devised a lottery scheme for the disposal of fifty townships; and 3,500,000 acres were disposed of in this way during the twelve years following the war. Altogether the States sacrificed their "wild lands" at trifling prices.

But, when William Penn, the founder and first legislator of the State which represented his grant, stipulated, in 1682, that for every five acres cleared one acre was to be reserved for forest growth by those who took title from him, that may properly be considered an attempt to inaugurate a conservative policy, dictated by wise forethought, -an attempt, which, however, bore little or no fruit.

Thoughtful men probably at all times looked with pity and apprehension upon the wasteful use of the timber as they do now, yet squander went on, just as it still does; but the apparently inexhaustible supplies in those early times called for no restriction in its use.

At the end of the eighteenth and beginning of the nineteenth century, a fuel-wood famine must have ap- 
peared in some parts of the country, just as in Germany at that time and for the same reasons, the wood having been cut along the rivers, which were the only means of transportation, and hence, the distance to which wood had to be hauled increasing the cost.

This was probably the reason why the Society of Agriculture, Arts and Manufactures of New York, after an inquiry by circular letter, issued in 1791, published, in 1795 , a report on the "best mode of preserving and increasing the growth of timber". This condition probably also led the wise Governor of New York, DeWitt Clinton, of Erie Canal fame, in a message in 1822, to forecast an evil day, because "no system of economy" for the reproduction of forest supplies was being adopted; and he added: "Probably none will be, until severe privations are experienced."

Like Great Britain at that time, the federal government became concerned as regards supplies for naval construction, and, by an act approved in 1799, appropriated $\$ 200,000$ for the purchase of timber fit for the Navy, and for its preservation for future use. Small purchases were made on the Georgia coast, but nothing of importance was done until, in 181\%, another act renewed the proposition of the first, and directed the reservation of public lands bearing live-oak or cedar timber suitable for the Navy, as might be selected by the President. Under this act, a reservation of 19,000 acres was made, in 1828, on Commissioners, Cypress and Six Islands, in Louisiana. Another appropriation of $\$ 10,000$ was made in 1828 , and some lands were purchased on Santa Rosa Sound, where, during a few years, an attempt at cultivation even was made, including sow- 
ing, transplanting, pruning, etc. This was done under a more general act of $182 \%$, by which the President was authorized to take proper measures to preserve the live oak timber growing on the federal lands. Under these acts, altogether some 244,000 acres of forest land were reserved in Alabama, Florida, Louisiana and Mississippi.

But, although another act, of 1831, provided for the punishment of persons cuting or destroying any Live Oak, Red Cedar, or other trees growing on any lands of the United States, no general conception of the need of a broad forest policy, or even of a special value attaching to the public timberlands dictated these acts, except so far as the securing of certain material, then believed necessary for naval construction, was concerned. Indeed, the act of 1831 remained for 60 years the only expression of interest in this part of the federal domain.

In those early times, the extent of our forest domain was entirely unknown, and the concern of occasional early voices in public prints regarding a threatened exhaustion of timber supplies can only be explained by the fact that, in the absence of railroads, the supplies near centers of civilization, or near drivable and navigable rivers, were alone of any account.

That the earlier propagandists of forest culture received scant attention was due to the fact that conditions soon changed; and with these changes the evil day seemed indefinitely postponed, and the necessity for forest culture apparently vanished. These changes were mainly wrought by the opening up of the west, by extending means of transportation through canals and railroads, and by distributing population, whereby the need for near-by home supplies was overcome; a con- 
tinental supply of apparently inexhaustible amount was brought into sight and within reach.

Meanwhile the population began to grow, immigrants began to pour in by the hundred thousand, and the westward stream opened up new country and new timber supplies, and a lumber industry of marvellous size began to develop. The small country mill, run in the manner of, and often in connection with, the grist mill, doing a petty business, by sawing, as occasion demanded, to order for home customers or export, gave way to the large mill establishment as we know it now; and with the development of railroad transportation and the settlement of the western country, especially the forestless prairies, the industry grew at an astonishing rate.

It is worth while to briefly trace the history of this industry, for the sake of which the need of conservative forest policies is essential.

That the petty method of doing business lasted until the middle of the century is evidenced by the census of 1840 , which reported 31,560 lumber mills, with a total product valued as $\$ 12,943,50 \%$, or a little over $\$ 400$ per mill. By 1876 , the product per mill had become $\$ 6,500$; by 1890 , with only 21,000 mills, it was $\$ 19,000$; in 1900 , nearly the same number of mills as were recorded in $1840(33,035)$ furnished a product of 566 million dollars, and in $190 \%$, the banner year of production, the cut of 28,850 mills was reported at over 40 billion feet, and the gross product per mill had grown to $\$ 23,000$, or a value for all of $\$ 666,641,36 \%$.

In the fifty years from 1850 to 1900 , the value of all forest products harvested increased from $\$ 59$ million to $\$ 567$ million, and in 1907 the value had risen to $\$ 1,280$ 
million, representing a consumption of 20 million cubic feet of forest-grown material.

Especially after the Civil War, the settlements of the West grew as if by magic; the railroad mileage more than doubled in the decade from 1865 to 1875 , and with it, the lumber industry developed by rapid strides into its modern methods and volume. How rapidly the changes took place may be judged from the fact that, in 1865, the State of New York still furnished more lumber than any other State; now it supplies only insignifcant amounts, a little over two per cent. of the total lumber cut.

In 1868, the golden age of lumbering had arrived in Michigan; in 18\%1, rafts filled the Wisconsin; in 18\%5, Eau Claire had 30, Marathan 30, and Fond du Lac 20 sawmills, now all gone; and mills at La Crosse, which were cutting millions of feet annually, are now closed. By 1882, the Saginaw Valley had reached the climax of its production, and the lumber industry of the great Northwest, with a cut of 8 billion feet of White Pine alone, was in full blast. The White Pine production reached its maximum in 1890 , with 8.5 billion feet, then to decrease gradually but steadily to less than half that cut in 1908. Southern development began to assume large proportions much later; at the present time, the lumber product of the Southern States has grown to amounts nearly double that of all the Northern States combined.

But not only the unparalleled and ever increasing wood consumption, which now has reached 250 cubic feet per capita, fire times that of Germany and ten times that of France, threatened the exhaustion of the natural sup- 
plies. Reckless conflagrations almost invariably followed the lumberman and destroyed generally the remaining stand, and surely the young growth. So common did these conflagrations become, that they were considered unavoidable, and though laws intended to protect forest property against fires were found on the statute books of every State, no attempt to enforce them was made.

No wonder that those observing this rapid decimation of our forest supplies and the incredible wastefulness and additional destruction by fire with no attention to the aftergrowth, began again to sound the note of alarm. Besides the writings in the daily press and other non-official publications, we find the reports of the Department of Agriculture more and more frequently calling attention to the subject.

In a report issued by the Patent Office as early as 1849 , we find the following significant language in a discussion on the rapid destruction of forests and their influence on water flow:

"The waste of valuable timber in the United States, to say nothing of firewood, will hardly begin to be appreciated until our population reaches $50,000,000$. Then the folly and shortsightedness of this age will meet with a degree of censure and reproach not pleasant to contemplate."

In 1865 , the Rev. Frederic Starr discussed fully and forcibly the American forests, their destruction and preservation, in a lengthy article in which, with truly prophetic vision, he says:

"It is feared it will be long, perhaps a full century, before the results at which we ought to aim as a nation will be realized by our whole country, to wit, that we should raise an adequate 
supply of wood and timber for all our wants. The evils which are anticipated will probably increase upon us for thirty years to come with tenfold the rapidity with which restoring or ameliorating measures shall be adopted.

\section{And again:}

"Like a cloud no bigger than a man's hand just rising from the sea, an awakening interest begins to come in sight on this subject, which as a question of political economy will place the interests of cotton, wool, cosl, iron, meat, and even grain, beneath its feet. Some of these, according to the demand, can be produced in a few days, others in a few months or a few years, but timber in not less than one generation. The nation has slept because the gnawing of want has not awakened her. She has had plenty and to spare, but within thirty years she will be conscious that not only individual want is present, but that it comes to each from permanent national famine of wood."

The article is full of interesting detail, and may be said to be the starting basis of the campaign for better methods which followed.

Another unquestionably most influential, official report was that upon "Forests and Forestry in Germany," by Dr. John A. Warder, United States Commissioner to the World's Fair at Vienna in 1873. Dr. Warder set forth clearly and correctly the methods employed abroad in the use of forests, and became himself one of the most prominent propagandists for their adoption in his own country.

About the same time appeared the classical work of George B. Marsh, our minister to Italy, "The Earth as Modified by Human Action," in which the evil effects on cultural conditions of forest destruction were ably and forcibly pointed out. 
Among these earlier publications designed to arouse public attention to the subject, should also be mentioned General C. C. Andrews' report on 'Forestry in Sweden,' published by the State Department in 1872.

The Census of $18 \% 0$ attempted for the first time a canvas of our forest resources under Prof. F. W. Brewer, as a result of which, the relative smallness of our forest area became known.

All these publications had their influence in educating a larger number to a conception and consideration of the importance of the subject, so that, when, in 1873, the committee on forestry of the American Association for the Advancement of Science was formed and presented a memorial to Congress, pointing out "the importance of promoting the cultivation of timber and the preservation of forests, and recommending the appointment of a commission of forestry to report to Congress," there already existed an intelligent audience. and although a considerable amount of lethargy and lack of interest was exhibited, Congress could be persuaded, in $18 \% 6$, to establish an agency in the United States Department of Agriculture, out of which grew later the Division of Forestry, a bureau of information on forestry matters. Dr. Franklin B. Hough, one of the signers of the memorial, was appointed to the agency. It is to be noted as characteristic of much American legislation, that this agency was secured only as a "rider" to an appropriation for the distribution of seed.

While these were the beginnings of an official recognition of the subject by the federal government, private enterprise and the separate States also started about 
the same time to forward the movement. In $186 \%$, the agricultural and horticultural societies of Wisconsin were invited by the legislature to appoint a committee to report on the disastrous effects of forest destruction. In 1869, the Maine Board of Agriculture appointed a committee to report on a forest policy for the State, leading to the act of 1872 "for the encouragement of the growth of trees, exempting from taxation for twenty years lands planted to trees, which law, as far as we know, remained without result. About the same time a real wave of enthusiasm regarding the planting of timber seems to have pervaded the country, and especially the Western prairie States. In addition to laws regarding the planting of trees on highways, laws for the encouragement of timber planting, either under bounty or exemption from taxation, were passed in Iowa, Kansas and Wisconsin in 1868; in Nebraska and New York in 1869; in Missouri in 1870; in Minnesota in 1871 ; in Iowa in 1872 ; in Nevada in 1873 ; in $\mathrm{Il}$ linois in 1874; in Dakota and Connecticut in 1875 ; and finally the federal government joined in this kind of legislation by the so-called timber-culture acts of 1873 and $18 \% 4$, amended in 1876 and $18 \% \%$.

For the most part these laws remained a dead letter. The encouragement by release from taxes, excepting the case of the federal government, was not much of an inducement; nor does the bounty provision seem to have had greater success, except in taking money out of the treasuries. Finally, these laws were in many cases repealed.

The timber-culture act was passed by Congress on March 3, 1873, by which the planting of timber on 40 
acres of land (or a proportionate area) in the treeless territory, conferred the title to 160 acres (or a proportionate amount) of the public domain. This law had not been in existence ten years when its repeal was demanded, and this was finally secured in 1891 , the reason being that, partly owing to the crude provisions of the law, and partly to the lack of proper supervision, it had been abused, and had given rise to much fraud in obtaining title to lands under false pretenses. It is difficult to say how much impetus the law gave to bono fide forest planting, and how much timber growth has resulted from it. Unfavorable climate, lack of satisfactory plant material, and lack of knowledge as to the proper methods, led to many failures.

A number of railroad companies, opening up the prairie States, planted at this time groves along the right of way for the sake of demonstrating the practicability of securing forest growth on the treeless prairies and plains.

There was also considerable planting of wind-breaks and groves on homesteads, which was attended with better results. Altogether, however, the amount of tree planting, even in the prairies and plains, was infinitesimal, if compared with what is necessary for climatic amelioration; and it may be admitted, now as well as later, that the reforestation of the plains must be a matter of co-operative, if not of national, enterprise.

At this time also, an effort was made to stimulate enthusiasm for tree planting among the homesteaders and settlers on the plains by the establishment of arbor days. From its inception by Governor J. Sterling Morton, and its first inauguration by the State Board. 
of Agriculture of Nebraska in 1872, Arbor Day gradually became a day of observance in nearly every State. While with the exception of the so-called treeless States, perhaps not much planting of economic value is done, the observance of the day in schools as one set apart for the discussion of the importance of trees, forests and forestry has been productive of an increased interest in the subject. Arbor days have perhaps also had a retarding influence upon the practical forestry movement, in leading people into the misconception that forestry consists in tree planting, in diverting attention from the economic question of the proper use of existing forest areas, in bringing into the discussion poetry and emotions, which have clouded the hardheaded practical issues and delayed the earnest attention of practical business men.

Private efforts in the East in the way of fostering and carrying on economic timber planting should not be forgotten, such as the offering of prizes by the Massachusetts Society for the Promotion of Agriculture (as early as 1804 and again in 1876), and the planting done by private land holders at Cape Cod, in Rhode Island, Virginia, and elsewhere. These efforts, to be sure, were only sporadic and unsystematic, and on no scale commensurate with the destruction of virgin forest resources.

A touching attempt of two noble Frenchmen to teach their American hosts a better use of their magnificent forest resource, although of little result, should never fail of mention. André Michaux and his son, André Francois, who, between 1785 and 1805, explored and studied the forest flora of the United 
States, and published a magnificent North American Sylva in three volumes, left in recognition of the hospitalities received, two legacies of $\$ 20,000$ for the "extension and progress of agriculture and more especially of silviculture in the United States," which bequests became available in 18\%0. The American Philosophical Society at Philadelphia, a trustee of one of the legacies, has devoted its income to beautification of Fairmount Park, providing a few lectures on forest botany and forestry, and collecting a forestry library, while the other legacy has been used by the Massachusetts Society for the Promotion of Agriculture to aid the botanical gardens at Harvard and the Arnold Arboretum, besides offering the prizes for tree planting referred to above.

\section{Development of a Forest Policy.}

This first period of desultory efforts to create public opinion on behalf of a more conservative use of forest resources was followed by a more systematic propaganda, in which the Division of Forestry, growing out of the agency in the Department of Agriculture, took the lead. This it did officially as well as by furnishing information to the officers of the American Forestry Association, soon after organized, with a view of educating public opinion.

The first forestry association had been formed on January 12, 1876, in St. Paul, Minn., largely through the efforts of Leonard B. Hodges, who was the first to make plantations in the prairies for the St. Paul and Pacific Railroad. This association was aided by State 
appropriations, which enabled it to offer premiums for the setting out of plantations, to distribute plant material, and also to publish and distribute widely a Tree Planters' Manual, revised editions of which were issued from time to time.

In 1875 , Dr. John A. Warder issued a call for a convention in Chicago to form a national forestry association. This association was completed, in 1876, at Philadelphia, but never showed any life or growth.

In 1882 , a number of patriotic citizens at Cincinnati called together a forestry congress, incited thereto by the visit and representations of Baron von Steuben, a Prussian forest official, when visiting this country on the occasion of the centennial celebration of the surrender of Yorktown.

A very enthusiastic and representative gathering, on April 25, was the result, lasting through the week, which led to the formation of the American Forestry Congress. In the same year, in August, a second meeting was held in Montreal, under the patronage of the Canadian government, and the name was changed to the American Forestry Association. In 1898, it began the publication of a propagandist journal, The Forester (later change̊d to Forestry and Irrigation, and now again to Conservation). It has now a membership of over 5,000. Much of the early educational propaganda was done through this association. Indeed, this association, holding yearly and intermediate meetings in different parts of the States, became the center of all private efforts to advance the forestry movement. Twelve volumes of its proceedings contain not only the history of progress in establishing a forest policy, but 
also much other information of value on forestry subjects.

Other local or State forestry associations were formed. from time to time, more or less under the lead of the national association, and exist now in almost every State, while several other societies, like the Sierra Nevada Club and the Mazamas of the Pacific coast, and State horticultural societies in various States, made the subject one to be discussed and to be fostered. The most active of these associations, since it was formed in 1886, publishing also a bi-monthly journal, Forest Leaves (at first less frequently), is the Pennsylvania State Forestry Association, which has succeeded in thoroughly committing its State to a proper forest policy, as far as official recognition is concerned.

Usually as a result of this associated private effort, the States appointed forestry commissions or commissioners. These commissions were at first for the most part instituted for inquiry and to make reports, upon. which a forest policy for the State might be framed. Others have become permanent parts of the State organization, with executive, or merely educational functions. Such commissioners of inquiry were appointed at various times in Connecticut (187\%), New Hampshire (1881 and 1889), Vermont (1882), New York (1884), Maine (1891), New Jersey (in Geological Survey 1894), Pennsylvania (1893), North Carolina (in Geological Survey 1891), Ohio (1885), Michigan (1899), Wisconsin (1897), Minnesota (1899), North Dakota (1891), Colorado (1885), California (1885).

It was but natural in a democratic country that these movements sometimes became the play balls of self- 
seeking men, political wire pullers, and grafters, or more often of ignorant amateurs and shallow sentimentalists, aided by half-informed newspaper writers. Infinite patience was required to steer through these rocks the ship of true economic reform, and to educate legislators and constituents to its true needs. The very first forestry congress was really conceived with a view of advancing political preferment of one of its organizers, and many another "forestry" meeting was utilized for a similar purpose, the new, catchy title attracting the gullible.

One of the first State forest commissions, well endowed to do its work, soon fell into the hands of grafters, and created such scandals that they led to its abolishment, and to a set-back in the movement everywhere. Arbor day sentimentalism discredited and clouded the issue before the business world; the movement was in constant danger at the hands of its friends. Antagonism of the lumber world was aroused by the false idea of what the reform contemplated, and, in the absence of technically trained foresters to instruct the public and the amateur reformers, and to convince legislators of the absolute need of discontinuing old established habits, progress was naturally slow, and experienced many setbacks.

It was a hard field to plow, grown up with the weed growth of prejudice and custom, and means and tools for the work were inadequate.

The federal government was naturally looked to to take the lead. The first two agents, employed in the Department of Agriculture to "report on forestry", unfortunately lacked all technical knowledge of the sub- 
ject, the first, a most assiduous worker, being a writer of local histories and gatherer of statistics, the second a preacher. The third, the writer himself, had at least the advantage of this technical training, but, at the same time, the disadvantage of being a foreigner who had first to learn the limitations of democratic government. Only the paltry sum of $\$ 8,000$ was at his disposal for plowing the ground, and even after the agency had been raised to the dignity of a Division, in 1886, for years no adequate appropriations could be secured, and hence the scope and usefulness of the work of the Division was ר hampered.

The Forestry Association, inaugurated with such a flourish of trumpets and with such a large membership at the start, had in the first two years dwindled to a small number of faithful ones, and was without funds when the writer became its secretary.

In spite of these drawbacks, the propaganda had progressed so far in 1891, that, through the earnest insistence of the then Secretary of the Interior, John W. Noble, who had been won over to the views for which the Division and the Association stood, a clause was enacted by Congress in "An act to repeal timber-culture laws and for other purposes", giving authority to the President to set aside forest reservations from the public domain. Again, this important legislation, which changed the entire land policy and all previous notions of the government's functions concerning the Public Domain, was not deliberately enacted, but slipped in as a "rider", at the last hour, in Conference Committee. In this connection the name of Edward A. Bowers, in $188 \%$ Special Agent in the Department of the Interior, and 
later Assistant Commissioner of the General Land Office, deserves mention as most active in securing this reservation policy.

Acting under this authority, Presidents Cleveland and Harrison proclaimed, previous to 1894, seventeen forest reservations, with a total estimated area of 17,500,000 acres.

The reservations were established usually upon the petition of citizens residing in the respective States and after due examination, the Forestry Association acting as intermediary.

Meanwhile no provision for the administration of the reserves existed, and the comprehensive legislation devised by the Chief of the Division of Forestry, which included a withdrawal and administration of all public timberlands, failed to be enacted, although in the Fiftythird Congress it was passed by both Houses, but failed to become a law merely for lack of time to secure a conference report. But the purpose of the advocates of forestry was to create such a condition as would compel Congress to act, by continually withdrawing forested lands that would lie useless until authority was given for their proper use and administration.

In order to secure influential support from outside, a committee of the Forestry Association induced the then Secretary of the Interior, Hoke Smith, in 1896, to request the National Academy of Sciences, the legally constituted adviser of the government in scientific matters, to inrestigate and report "upon the inauguration of a rational forest policy for the forested lands of the United States." After an unnecessary so-called "junket" of a committee of the Academy to investigate the public 
timberlands, a preliminary report was submitted recommending the creation of thirteen additional reservations, with an area of over 20 million acres, and later a complete report was made with practically the same recommendations which had been urged by the Forestry Association.

President Cleveland, heroically, proclaimed the desired reserves all on one day, Washington's birthday, 1897, without the usual preliminary ascertainment of local interests, and immediately a storm broke loase in the United States Senate, which threatened the overthrow of the entire, toilsomely achieved reservation policy; and impeachment of the President was strongly argued in a two-day (Sunday) session. Congress, however, came to an end on March 4, before it had taken any action, but as it had also failed to pass the annual Sundry Civil Appropriation Bill, it was immediately recalled in extra session.

Then, again, by a clever trick and in an indirect and surreptitious manner, instead of by open, direct and straightforward consideration and deliberation of a proper policy, most important legislation was secured in the Sundry Civil Appropriation Bill, which provided for the temporary suspension of the reservations lately set aside until they could be more definitely delimited, private claims adjusted, and agricultural lands excluded, by a survey, for which $\$ 150,000$ was appropriated to the United States Geological Survey. The agricultural lands were then to be returned to the public domain for disposal. At the same time, provisions for the administration of the remaining reservations, much in the sense of the legislation advocated by the Division of Forestry 
and the Forestry Association, and especially for the sale of timber, were hung on to this appropriation clause. Under this act the reserves are still administered.

If the interior history of this bit of legislation were revealed, it would probably appear that, not conception of the importance of the subject, but the need for the employment of a certain organized survey party in the Geological Survey, was at the bottom of it.

While this law had set aside one year, and a limited sum, to accomplish the survey, this could not, of course, be done, and hence appropriations were continued, and the date for the segregation of the lands was deferred sine die. For vears this forest surver continued. giving

the forest reservations was secured, and rules and regulations for their administration were formulated by the Commissioner of the General Land Office, marking the beginning of a settled policy on the part of the United States government to take care of its long neglected forest lands.

Meanwhile, the Division of Forestry had continued to bring together and distribute in the shape of reports, bulletins, circulars, addresses and letters, such informa- 
timberlands, a preliminary report was submitted recommending the creation of thirteen additional reservations, with an area of over 20 million acres, and later a complete report was made with practically the same recommendations which had been urged by the Forestry Association.

President Cleveland, heroically, proclaimed the desired reserves all on one day, Washington's birthday, 189\%, without the usual preliminary ascertainment of local interests, and immediately a storm broke loose in the United States Senate, which threatened the overthrow of the entire, toilsomely achieved reservation policy; and impeachment of the President was strongly argued in a two-day (Sunday) session. Congress, however,

Correction-page 419-the last two lines in the third paragraph:

By 1905, some 110,000 square miles had been examined, when the whole matter was turned over to the Forest Survey.

for the temporary suspension of the reservations lately set aside until they could be more definitely delimited, private claims adjusted, and agricultural lands excluded, by a survey, for which $\$ 150,000$ was appropriated to the United States Geological Survey. The agricultural lands were then to be returned to the public domain for disposal. At the same time, provisions for the administration of the remaining reservations, much in the sense of the legislation advocated by the Division of Forestry 
and the Forestry Association, and especially for the sale of timber, were hung on to this appropriation clause. Under this act the reserves are still administered.

If the interior history of this bit of legislation were revealed, it would probably appear that, not conception of the importance of the subject, but the need for the employment of a certain organized survey party in the Geological Survey, was at the bottom of it.

While this law had set aside one year, and a limited sum, to accomplish the survey, this could not, of course, be done, and hence appropriations were continued, and the date for the segregation of the lands was deferred sine die. For years this forest survey continued, giving rise to magnificent volumes, issued from the Geological Survey, describing the forest reservations-a very useful, educational piece of work, not at all contemplated by the legislation-for which not less than $\$ 1.5$ million have been expended. Some 77,000 square miles have been surveyed-and the end is not yet.

Thus it happened, almost by accident, that finally the aims of the reformers were realized, the appointment of forest superintendents, rangers, etc., to take charge of the forest reservations was secured, and rules and regulations for their administration were formulated by the Commissioner of the General Land Office, marking the beginning of a settled policy on the part of the United States government to take care of its long neglected forest lands.

Meanwhile, the Division of Forestry had continued to bring together and distribute in the shape of reports, bulletins, circulars, addresses and letters, such informa- 
tion useful for the education of the public, of wood consumers, and timberland owners, as its limited appropriations permitted, undertaking also some scientific investigations, especially in the line of timber physics.

Soon after, in July, 1898, when the writer resigned his position as Chief of the Division of Forestry, to organize the first professional forest school, the New York State College of Forestry, Mr. Gifford Pinchot, took charge of the Division. Young, ambitious, aggressive, with some knowledge of forestry acquired in Europe and with influential connections and a large fortune, he easily secured the first need for effective sowing $\wedge$ on the well-plowed field before him-appropriations. Whatever had been feebly begun could be broadly, sometimes lavishly, extended, and the new idea of making "working plans" for private timberland owners could be developed-a great educational work, which, earlier, when even co-operation with State institutions was considered a questionable proposition, would have been turned down as too patermal.

In five years the appropriations had increased tenfold, to over $\$ 250,000$; and in the first decade of the new regime, around $\$ 3,000,000$ had been spent on forestry investigations, not counting expenditures on forest reservation account.

A further strong support came into the field, when Mr. Roosevelt became President of the United States, in 1901, and unreservedly threw his over-powering influence into the balance, to advance forest policies.

Owing to his interest, the withdrawal of public timberlands from entry proceeded at a rapid rate: by 1902 , the reservations had grown to 65 million acres; in 1905 , 
there were over 100 million acres included; and by the end of his administration, 175 million acres had been placed in reservation.

The anomalous condition, which placed the survey of the forest reserves in the Geological Survey, their administration in the Land Office, and the scientific or technical development of forestry in the Department of Agriculture, was finally ended in 1904, when, on February 1st, the whole matter was placed in the hands of the Department of Agriculture, with its Forestry Division, which had been changed into a Bureau of Forestry, and then changed its name again to Forest Service.

With this transfer, it may be said, the federal forest policy was fully established, at least for its own lands, and all that remains to be done is the perfection of details in their administration and the development of silvicultural methods.

With appropriations which now (190\%) exceed \$950,000 for investigating work alone, limitless opportunity seems to be open to extend the many directions of inquiry and solve the silvicultural problems, and satisfy the educational function of this government agency.

But besides the administration of the federal timberlands and the educational and other assistance of private owners, a further expansion of the Forest Service is developing under the paternalistic and socialistic tendencies referred to before, which may ultimately lead to the purchase and federal control of forest reserves in the Eastern States. Such expansion was, indeed, proposed in the establishment of reserves in the White Mountains and the Southern Appalachians, propositions which 
have been resisted by Congress for the last seven years, but with ever weakening resistance.

Meanwhile the single States have begun to develop their own policies.

Outside of legislation aiming at protection against forest fires-which nearly every State possessed from early times, ineffective for lack of machinery to carry it into effect-and outside of the futile attempts to encourage timber planting referred to, no interest in timberlands was evinced by State authorities for the first two-thirds of the century, since practically all these lands had been disposed of to private owners, and the authorities did not see any further duties regarding them.

The first State to institute a commission of inquiry was Wisconsin, in $186 \%$; but with the rendering of the report, prepared by I. A. Lapham, one of the active early propagandists-the matter was allowed to mature for thirty years.

The next State to move, in a feeble way, in 1876 , was Minnesota, the legislature making an annual grant of money to its forestry association. The appointment of commissions of inquiry then became fashionable.

New Hampshire appointed such a commission in 1881, which reported in 1885, without result, and another commission in 1889, whose report, in 1893, led to the establishment of a permanent commission of inquiry and advice, with a partial supervision of forest fire laws. Vermont followed suit with a commission of inquiry, in 1882, whose report made in 1884 , remained without consequences.

In Michigan the expedient was resorted to of consti- 
tuting the State Board of Agriculture a commission of inquiry, whose report, published in 1888, had also no consequences except those of an educational character.

Similarly, the State of Massachusetts ordered the State Board of Agriculture in 1890, to inquire "into the consideration of the forests of the State, the need and methods of their protection", with similar results, or lack of result.

In New Jersey, the matter was referred to the State Geologist, who, since 1894, has made reports on forest conditions and needs. Similar reference of the subject ras made in the State of North Carolina, in 1891, and in West Virginia.

The first more permanent State institution deliberately established as an educational and advisory agent was the Forestry Bureau of Ohio, in 1885, which published a number of annual reports, but eventually collapsed for lack of support.

In the same year, three important States, New York in the East, Colorado in the Middle States, and California in the West, seemed simultaneously to have awakened to their duty, largely as a result of the propaganda of the American Forestry Association.

In California, a State Board of Forestry was instituted, with considerable power and ample appropriations, which, however, eventually fell into the hands of unscrupulous politicians and grafters, the resulting scandals leading to its abolishment in 1889 .

In Colorado, which when admitted to Statehood in 18i6, had, in its Constitution, directed the general assembly to legislate on behalf of the forestry interests of the State, these interests were rather tardily committed 
to a forest commissioner, who was charged to organize county commissioners and road overseers throughout the State as forest officers in their respective localities, to act as a police force in preventing depredations on timbered school lands and in enforcing the fire laws. Col. E. T. Ensign, who had been most instrumental in bringing about this legislation, was appointed commissioner, and, with singular devotion, in spite of the enmity aroused by his activity, which eventually led to a discontinuance of appropriations, tried, for a number of years, to execute this law. With his resignation from the office, this legislation also fell into innocuous desuetude.

In New York, concern in the water supply for the Erie Canal, had led such a far sighted statesman as Horatio Seymour, twice Governor of the State and once running for the Presidency, to conceive the need of preserving the Adirondack watershed in State hands. Accordingly a law was passed, in 1872, naming seven citizens, with Horatio Seymour chairman, as a State park commission, instructed to make inquiries with the view of reserving or appropriating the wild lands lying northward of the Mohawk, or so much thereof as might be deemed expedient, for a State park. The commission, finding that the State then owned only 40,000 acres in that region, and that there was a tendency on the part of the owners of the rest to combine for the enhancement of values should the State want to buy, recommended a law forbidding further sales of State lands, and their retention when forfeited for the nonpayment of taxes.

It was not until eleven years later, in 1883, that this recommendation was acted upon, when the State through 
the non-payment of taxes by the owners had become possessed of 600,000 acres.

In 1884, the comptroller was authorized to employ "such experts as he may deem necessary to investigate and report a system of forest preservation". The report of a commission of four members was made in 1885 , but the legislation proposed was antagonized by the lumbermen's interests. The legislature finally passed a compromise bill, which the writer had drafted at the request of Senator Lowe, entitled "An act establishing a forest commission, and to define its powers, and for the preservation of forests", the most comprehensive legislation at that time.

The original forest commission, appointed under the act of 1885 , was superseded in 1895 , by the commission of fisheries, game, and forests, which brought allied interests under the control of a single board of fire members appointed by the Governor for a term of five years. Finally, in 1903, the commission was changed to a single commissioner.

Here, then, for the first time on the American continent, had the idea of State forestry, management of State lands on forestry principles, taken shape; a new doctrine of State functions had gained the day. Not only was the commission charged to organize a service, with a "chief forester" and "underforesters", to administer the existing reserve according to forestry principles, but also from the incomes to lay aside a fund for the purchase of more lands to constitute the State forest preserve. Unfortunately, instability of purpose, the characteristic of democracy, spoiled the dream of the forester. Both, commission and chief forester were, of 
course, political appointees, and, rightly or wrongly, fell under the suspicion, when proposing the sale of stumpage, that they were working into the hands of lumbermen. A set of well-meaning but ill-advised civic reformers succeeded, in 1893, in securing the insertion into the Constitution, then being revised, of a clause preventing the cutting of trees, dead or alive, on State lands, declaring that they shall forever be kept as "wild lands". Later, this constitutional provision was deliberately set aside by the commission, which began to plant up some of the fire-wasted areas, the legislature appropriating money for this breach of the Constitution because it was popular; and lately permission has also been granted by the legislature to remove trees from burnt areas in order to reduce the fire danger-the foolish objection of a Constitution notwithstanding.

In 1897, new legislation was passed to authorize the State to purchase additional forest lands within a prescribed limit, to round off the State's holdings, a special agency, the Forest Preserve Board, being constituted for that purpose. Under this law, some $\$ 3,500,000$ have been spent, and by $190 \%$, over one and a half million acres had been added to the State Forest Preserve. This large area is withdrawn from rational economic use, reserved for a pleasure ground of wealthy New Yorkers, who have located their camps in the "wilderness" under the avowed assumption that the State can be forced to maintain forever this anomalous condition.

In later years, private planting has been encouraged by the Commission selling plant material from the State nurseries at low rates.

The most important administrative function of the 
Commission has been the reduction of forest fires, in which, also owing to political conditions, only partial success has been attained. The legislation of 1885 for the first time attacked this problem in a more thorough manner, providing for the organization of a service, and this served as an example to other States, who copied and improved on it. Notably the forest fire legislation of Maine (1891), of Wisconsin (1895), and of Minnesota (1895) was based on this model.

Another of the large States to start upon and, differently from New York, to develop consistently a proper forest policy, was the State of Pennsylvania. As a result of a persistent propaganda by the Pennsylvania Forestry Association, formed in 1886, and especially by its active secretary, Dr. J. T. Rothrock, a commission of inquiry was instituted in 1893. Before its report was established, the legislature of 1895 provided for an executive Department of Agriculture, and included in its organization a provision for a Division of Forestry, the botanist member of the previous commission, Dr. Rothrock, being appointed Commissioner of Forestry at the head of the Division. Two years later the final legislation, which firmly established a forest policy for the State, was passed, namely for the purchase of State forest reservations. All later legislation was simply in expansion of these propositions. By 1908, the State had acquired by purchase, wild, mostly culled lands to the extent of over 800,000 acres, and the Commission had progressed far towards providing for their management and recuperation.

The unusually disastrous conflagrations of 1894 , the growing conviction that the pleaders of the exhausti- 
bility of timber supplies were right, accentuated by a rapid decline in White Pine production, and a rapid, and, indeed, almost sudden, rise in stumpage prices, the example which the federal government had set in withdrawing public timberlands from spoliation, together with an increasing number, not only of advocates of saner methods, but of technically educated men, which came from the schools lately organized-all these influences had worked as a leaven in all parts of the country so as to bring in the new century with a $\checkmark$ realization of the seriousness of the situation. And, within the first seven years of the century, the change of attitude, at least, was almost completed in all parts of the country, and among all classes, the lumbermen and others depending directly on wood supplies becoming especially prominent in recognizing the need and value 1 of forestry.

State after State came into line in recognizing that it had a duty to perform, and in some way gave expression to this recognition, so that, by 1908 , hardly a State was without at least a germ of a forest policy.

Two principles had been recognized as correct and were brought into practice, namely, that the forest interests of the State called for direct State activity, and that eventually the State must own and manage at least portions of the forest area. The first principle took shape in appointing single State foresters, [as in Maine (1891 and 1903); in Massachusetts (1904); in Connecticut (1903); in Maryland (1905); in Vermont (1906) ; in Rhode Island (1906)] ; or Commissions or Boards [as in New York (1885), changed to a single comissioner with Superintendent and State foresters 
in 1903; in Pennsylvania (1901); in New Hampshire (1893) ; Maryland with a State forester (1905); Wisconsin, with a State forester (1905); Indiana (190103) ; Louisiana, with a State forester (1904) ; Michigan (1899); Minnesota (1899); California (revived, with a State forester, in 1905); Washington, with a State forester (1905); Kentucky (1906); in New Jersey, with a State forester (1904); Alabama (1907).]

A very important feature in these appointments was the fact, that, more and more professional or technically educated men displaced the merely political appointees, or were at least added to the commissions.

The idea of State forests found expression, more or less definitely, in setting aside forest reservations or else in enabling the State to accept and administer donations of forest lands. Among the States recognizing this principle were New Hampshire, Connecticut, New Jersey, Michigan, Wisconsin, Minnesota, Indiana, California.

Where neither of these two principles had as yet found application, at least some agency was established to give advice and investigate or experiment in matters of forest interests, and sometimes to offer assistance to private woodland owners or planters, as in Delaware, Ohio, North Carolina, etc.

Meanwhile, largely through the influence and with the co-operation of the federal Bureau of Forestry, private owners had begun, if not to apply, at least to study the possibility of the application of forestry to their holdings. The Bureau prepared "working plans" which were now and then followed in part, or at least led to attempts at a more conservative method of log- 
ging. Notably, various paper and pulp manufacturers realized the usefulness of more systematic attention and conservative methods in the use of their properties. In this connection the object lesson furnished by $\mathbf{M r}$. G. K. Vanderbilt on his Biltmore Estate in North Carolina, which was begun by $\mathrm{Mr}$. Pinchot and conducted by Dr. C. A. Schenck, a German forester, requires special mention as the first, and for nearly 20 years continued experiment in applying forestry methods systematically in America. At present writing the continuance of this experiment is in doubt.

With the second decade of the century, we shall enter upon the flood tide of development, when no more need of argument for its necessity, and only the question of practicable methods, will occupy us.

So far, silviculturally, the selection forest, i. e., culling the best and the stoutest, practiced hitherto by the lumberman, but carried on somewhat more conservatively, is apparently still the only method advocated by the Forest Service. This so-called conservative lumbering is, to be sure, the transition to better methods. According to reports of the federal Forest Service in $190 \%$, some million acres of timberland were under forest management or conservatively lumbered.

Planting of waste lands, as distinguished from planting in the prairies, which had, sporadically and in a small way, been done by individuals here and there for many years, is practised in ever increasing amount, both by State administrations and by private owners; the New York State College of Forestry starting such planting in its College Forest on a larger scale and systematically, in 1899. At present writing, the forestry de- 
partment of the Pennsylvania Railroad Company is perhaps the largest single planter in the country, having set out orer three million trees (by 1908), with the arowed purpose of growing railroad ties.

By 1908, popular interest in forest conservation had become so keen, and at the same time paternalistic tendencies so fully dereloped by the Roosevelt administration-the federal government haring entered upon extensive plans of reclaiming lands by irrigation, and preparing to develop water powers, and inland waterways,that the time scemed ripe to bring all these conservative forces into unity.

The President called together in conference the governors of all the States with their advisers, together with the presidents of the rarious national societies interested, and others, to discuss the broad question of the conservation of natural resources.

As a consequence national and State Conserration Commissions were formed in all parts of the Enion, and a new era of actire interest in economic derelopment seems to have arrired.

4. Education and Literature. The primary education of the people at large and of their governments in particular, the propaganda for the economic reform contemplated by the forestry morement, was carried on, as stated, by the federal Division of Forestry and especially by the so-called forestry associations which sprang up in all parts of the country, by means of their annual and special meetings, aided by the general press and sometimes by special publications.

The first Journal of Forestry, a monthly publication, 
ventured into the world as a private enterprise, edited by Dr. Hough, soon after the Forestry Congress in Cincinnati, but it survived just one year, vanishing for lack of readers. This was followed by irregularly appearing Forestry Bulletins, of which the writer prepared four under the aegis of the American Forestry Association.

In 1886, the Pennsylvania Forestry Association began the publication of a bi-monthly journal, Forest Leaves, which has persisted to this day. In 1905, Dr. John Gifford launched another bi-monthly, the New Jersey Forester, soon to change its name to The Forester, and under that name, three years later, taken over by the American Forestry Association, continued as Forestry and Irrigation and now as Conservation. Now, half a dozen or more similar publications emanate from the various State Associations. In this connection there should not be forgotten the journal, Garden and Forest, edited by Professor C. S. Sargent, which for ten years, from 1888 to 1897 , did much to enlighten the public on forestry matters.

Some provision for technical education was made long before opportunity for its application had arisen, and, indeed, before any professional foresters were in existence to do the teaching. The new doctrine attracted the attention of educational institutions, and the desire to assist in the popular movement led to the introduction of the subject, at least by name, into their curricula; the professor of botany or of horticulture, adding "forestry" to his title, and explaining in a few lectures the objects, and, as far as he knew them, the methods of forestry; or, at least some lectures on dendrology and forest geography were introduced in the botanical 
courses. By $189 \%$, twenty institutions-land grant colleges - had in this way introduced the subject.

Perhaps the first attempt to present systematically a whole course of technical forestry matter to a class of students was a series of twelve lectures, delivered by the writer, at the Massachusetts College of Agriculture in $188 \%$.

The era of professional forest schools, however, was inaugurated in 1898, when the writer organized the New York State College of Forestry at Cornell University, and almost simultaneously Dr. Schenck opened a private school at Biltmore.

A year later, another Forest school was opened at Yale University, an endowment of the Pinchots, father and sons. In 1903, the University of Michigan added a professional department of forestry, and then followed a real flood of educational enthusiasm, one institution after another seeing the necessity for adding the subject as an integral part to its courses. Before there were enough competent men in the field, some twenty colleges or universities called for teachers, besides several private institutions. An inevitable result of this over-production of forest schools and of foresters all at once must be an overcrowding of the profession with mediocre men before the profession is really fully established.

Brief reference to the history of the first school, established by the State of New York, may be of interest, as exemplifying in a striking manner the political troubles besetting reforms under republican conditions. But for a similar occurrence in France (see p. 210), this case might be unique in the history of educational institutions. Although the school thrived almost beyond ex- 
laving in its fourth year grown in numbers iv $1 v, \ldots \ldots$ er than any French or German forest school at the time, and readily finding employment for its graduates, it suddenly came to an end in 1903. Its appropriation, unanimously voted in the Legislature, was vetoed by the Governor, on the alleged ground that the silvicultural methods applied in the demonstration forest of the College "had been subjected to grave criticism". It is true the only silvicultural method officially sanctioned (by the Forest Service), the selection forest, had not been applied, yet the war against the College being waged by two wealthy bankers of New York and the well-known character of the then Governor suggest that other "considerations" than mere criticism of professional judgment were at the bottom of his action. As from the start, the federal Forestry Bureau naturally continued in ever increasing degree to be the educator of the nation, not only as regards popular conceptions and attitudes, but as regards technical matter. Its bulletins, circulars, and reports on the subjects which come under investigation form the bulk of the American literature on the technical side of the subject. During the first 20 years of its existence, some 20,000 pages of printed matter were produced, and the next decade increased the crop of information apace. At first intended for popular propaganda, the matter printed was naturally argumentative, statistical and descriptive, but gradually more and more technical matter filled the pages, and now most of the publications are of technical nature.

One of the first extensive and important lines of investigation undertaken by the Division was that into 
the characteristics and strength, the timber physics, of American woods, which in its comprehensiveness commanded the admiration of even the Germans, and gave rise to a series of reports. The biology of American species, more or less exhaustively studied, was also begun in the old Division, as well as forest surveys, etc.

By 1902, enough professional interest was in the country to make the publication of a professional journal possible and desirable, the Forestry Quarterly being launched by the writer, with a Board of Editors chosen mainly from the forest schools.

The first association of professional foresters was formed in 1900 - the Society of American Foresterswhich issues from time to time proceedings containing technical discussions.

The technical book literature, partly due, no doubt, to the overpowering publication facilities of the federal government, is still scanty, and good textbooks especially are still lacking in most branches.

A series of ephemeral popular books answered the demands of earlier days, but outside of Professor Henry S. Grares' volume on Forest Mensuration and a few minor aid books and lecture notes, there is as yet nothing of prominent value to be recorded.

Three monumental works can be mentioned in the dendrological line, however, namely the 10th volume of the XII Census (1880) on the Forests of North America; Micheaux and Nutall's North American Silva in 5 rolumes, 1865 ; and C. S. Sargent's Silva of the United States, in 13 magnificent volumes,-three publications which can take rank with any similar literature anywhere. 


\section{INSULAR POSSESSIONS.}

The Spanish War, in 1898, brought to the United States new outlaying territory, over 150,000 square miles, in three locations, the relationship as regards government varying in the three cases, namely Porto Rico, the Sandwich Islands, and the Philippine Islands, besides several smaller islands in the Pacific Ocean.

While the latter are only temporarily under control or tutelage of the United States, and are expected sooner or later to attain complete self government, Hawaii was annexed as a Territory in the same sense as all other Territories, the inhabitants having become citizens of the United States, while Porto Rico is a dependency with partial self-government, but its inhabitants do not enjoy citizenship in the States.

All these islands are located in the tropics and hence the composition of the forest is of tropical species.

Commercially, the forests of Porto Rico and of Hawaii are relatively of little value, but their protective value is paramount, and a conservative policy is needed in order to preserve the water supply for agricultural use (sugar plantations in Hawaii) and to prevent erosion.

For Porto Rico, a beginning of forest policy was made by setting aside, in 1903, the Luquillo Forest Reservation, some 20,000 acres in the Eastern mountainous part of the island, which is under direct control of the United States government. The rest of public lands and forests was placed under the Department of the Interior of the island.

In Hawaii, even before annexation, a movement on 
the part of the Sugar Planters Association was made in 189\%. to induce the insular government to devise protective measures. The result was the appointment of a Committee who made a report in which the writer had a hand. But not until 1903 was a Board of Commissioners of Agriculture and Forestry established, a Superintendent of Forestry appointed, an organization of district foresters effected, and a number of forest reservations established. The principle of State forest was fully recognized by planning the gradual withdrawal of some 300,000 acres and by beginning the extension of forested area by plantations. Distribution of plant material and of advice to planters is also part of the policy. Annual Reports are issued which attest the good common sense in the administration.

In the Philippine Islands, a territory of 120,000 square miles, largely mountainous, not only the protective but the commercial value of the timberlands is considerable.

The extent is variously estimated as covering between 40 and 50 million acres ( $50 \%$ of total area), much of it virgin, and 16 million acres of it commercially valuable. Of the seven hundred odd species of trees, mostly heavy woods, composing the forest, some 160 are marketable at home and in China; yet almost fifty per cent. of the home consumption is imported from the States, owing to absence or inaccessibility of softwoods, and high cost due to excessive expense of present logging methods.

When the United States took charge of the islands it was found that the Spaniards had since 1863 a forestry service, manned by Spanish foresters, and in the lower 
ranks by Filipinos. To be sure, the activities of this forestry bureau went hardly beyond the collection of dues for timber licenses, which yielded little more than the cost of the service, although on paper excellent instructions were found elaborated.

It so happened that an officer of the American army, Captain George P. Ahern, had for some time given attention to forestry matters in the States, and he naturally was placed in charge of this bureau, in 1900. There were found to be around one million acres private and church property, the rest being considered State lands, but all private owners were required to register their holdings before being allowed to exercise their rights. A system of licenses for cutting timber, and of free use permits to the poor population was continued after Spanish models. Not only was gradually an efficient administration secured, but the technical side of dendrological and silvicultural knowledge was as rapidly as possible developed under the able administration of Captain Ahern, a continuously growing literature being the result. 



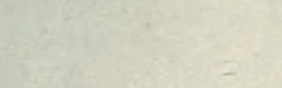





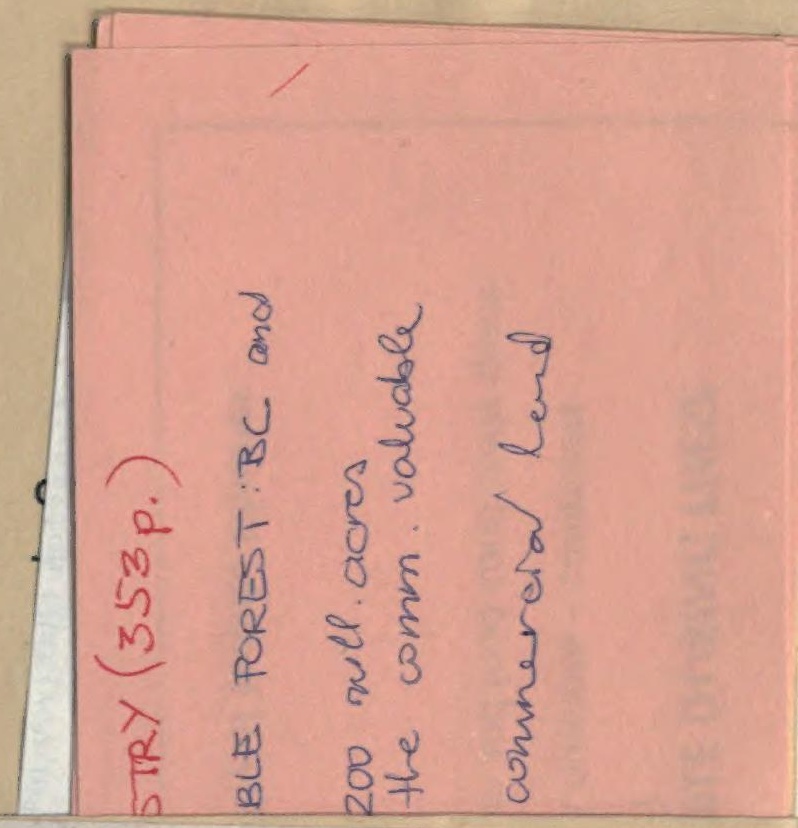

SD

131 F4

Forestry
Fernow, B.E.

History of forestry 
